\title{
U.S. GEOLOGICAL SURVEY SECOND NATIONAL SYMPOSIUM ON WATER QUALITY: ABSTRACTS of the Technical Sessions, Orlando, Florida, November 12-17, 1989
}

By Gary L. Pederson and Martha M. Smith, compilers

\section{U.S. GEOLOGICAL SURVEY}

Open-File Report 89-409

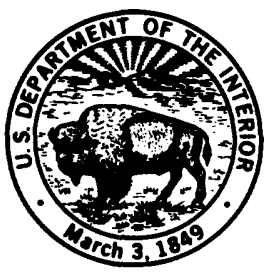




\section{DEPARTMENT OF THE INTERIOR \\ MANUEL LUJAN, JR., Secretary}

\section{U.S. GEOLOGICAL SURVEY}

Dallas L. Peck, Director

The use of brand, company, or trade names in these abstracts is for identification purposes only and does not constitute endorsement by the U.S. Geological Survey.

For additional information write to:

U.S. Geological Survey Office of Water Quality 412 National Center Reston, Virginia 22092
Copies of this publication can be purchased from:

U.S. Geological Survey Books and Open-File Reports Box 25425, Federal Center Denver, Colorado 80225 


\section{FOREWORD}

The Water Resources Division of the U.S. Geological Survey sponsored the First National Symposium on Water Quality in 1977. Since that time, vast changes have occurred in the Division's water-quality programs, suggesting that a national meeting at which a large share of the Division's professionals could meet and share a common updating of water-quality skills was needed.

During the years subsequent to 1977 , the Division has undertaken major programs such as the National Water Quality Assessment, Toxic Substances Hydrology and Irrigation Drainage. Earlier programs, such as the National Stream Quality Accounting Network and Atmospheric Deposition, have matured and been significantly redirected.

Considering the above, the need for the Second National Symposium on Water Quality was evident and it was subsequently scheduled for November 12-17, 1989, in Orlando, Florida. This report includes abstracts for all papers and posters that have been accepted for presentation at the Second National Symposium on Water Quality. All presented abstracts are listed alphabetically by senior author in the report. I believe these abstracts reflect an excellent cross section of ongoing water-quality programs and activities, not only in the Water Resources Division, but also in other Federal, State, and local government agencies as well as universities.

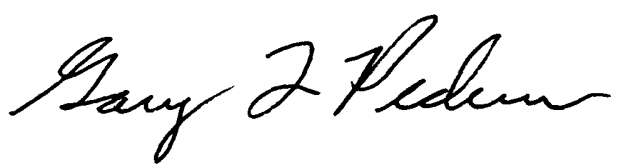

Gary L. Pederson, Technical Chairman Second National Symposium on Water Quality 
For ease in locating abstracts in this publication, they have been arranged alphabetically, by senior author, as underlined in the Table of Contents. Page numbers for each abstract also appear in the program listing, arranged by session number, which immediately follows the Table of Contents. The presenting author is identified in the program listing and on the abstracts. 


\section{CONTENTS}

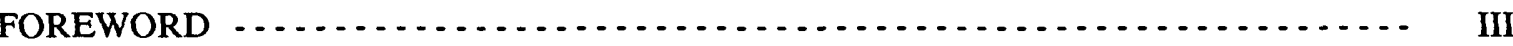

PROGRAM LISTING

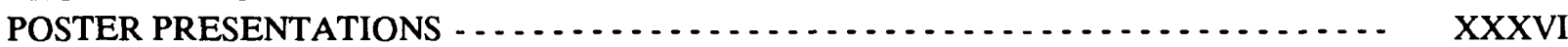

APPLICATION OF A WATER-QUALITY INDEX

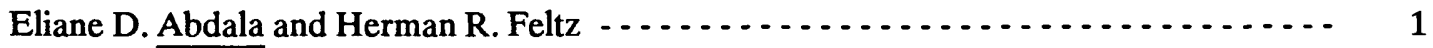

ABILITY OF MICROBIAL COMMUNITIES FROM A PRISTINE AQUIFER TO

DEGRADE XENOBIOTIC COMPOUNDS

C. Marjorie Aelion and Frederic K. Pfaender $\ldots \ldots \ldots \ldots \ldots \ldots \ldots \ldots \ldots \ldots \ldots \ldots$

A COMPUTERIZED SYSTEM FOR THE DETECTION AND ANALYSIS OF LONG-TERM TRENDS IN WATER-QUALITY DATA

Richard B. Alexander, Terry L. Schertz, and Dane J. Ohe $\ldots \ldots \ldots \ldots$

PRESIDENT'S INITIATIVE ON ENHANCING WATER QUALITY

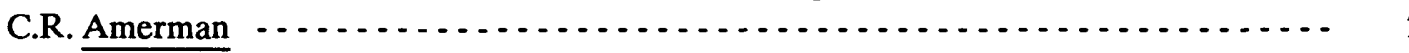

FIELD MEASUREMENTS OF DISSOLVED NITROGEN AND OXYGEN IN GROUND

WATERS OF THE BLACK HILLS AREA, SOUTH DAKOTA

Mark T. Anderson and Janelle M. Williams $\ldots \ldots \ldots \ldots \ldots \ldots \ldots \ldots \ldots \ldots \ldots \ldots$

USDA RESEARCH PLAN FOR WATER QUALITY

Loris E. Asmussen $\ldots \ldots \ldots \ldots \ldots \ldots$

VOLATILE ORGANIC ACIDS IN ORGANIC-RICH AQUIFERS

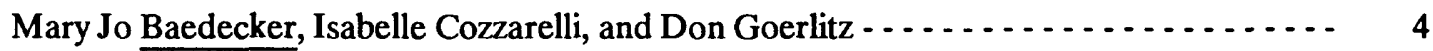

NITRATE IN GROUND WATER AT A FARM IRRIGATED WITH TREATED SEWAGE

AND INORGANIC FERTILIZERS, TALLAHASSEE, FLORIDA

Marian P. Berndt

SURFACE-WATER QUALITY OF THE UPPER ILLINOIS RIVER BASIN IN ILLINOIS, INDIANA, AND WISCONSIN: ANALYSIS OF EXISTING INFORMATION

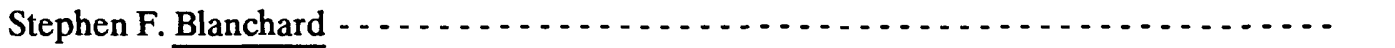

COMBINATION OF SURFACE GEOPHYSICS AND BOREHOLE MEASUREMENTS TO DEFINE GROUND WATER POLLUTION PLUMES

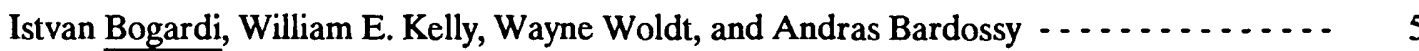

GEOCHEMISTRY OF IRON IN A SAND DUNE AQUIFER USED FOR MUNICIPAL AND

INDUSTRIAL WATER SUPPLY NEAR COOS BAY AND NORTH BEND, OREGON

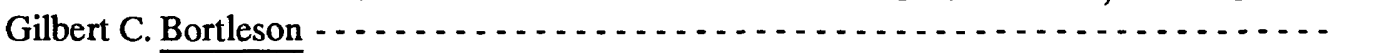

HYDROCARBON CONTAMINATION WITHIN THE UPPER FLORIDAN AQUIFER IN ORLANDO, FLORIDA

L.A. Bradner - 
A COMPARISON OF ANALYTICAL TECHNIQUES USED FOR THE DETERMINATION OF VOLATILE AND SEMIVOLATILE ORGANIC CONTAMINANTS IN GROUND WATER

Doug Cain, James F. Pankow, Daniel T. Chafin, William T. Foreman, Steven D. Zaugg, Lorne F. Isabelle, Michael J. Liszewski, Jacob Gibs, Brooke F. Connor, Marilyn G. Werner, Ronald Baker, and Roderick F. Ortiz

GEOCHEMICAL CONSEQUENCES OF RAPID SEDIMENTATION IN RESERVOIR LAKES RECEIVING MINING WASTES

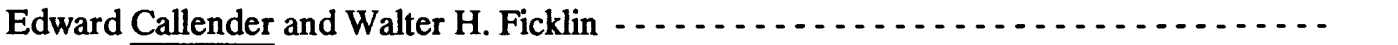

COMPARISON OF SOLUTE COMPOSITION OF PRECIPITATION AND DECIDUOUS AND CONIFEROUS THROUGHFALL IN A PIEDMONT WATERSHED

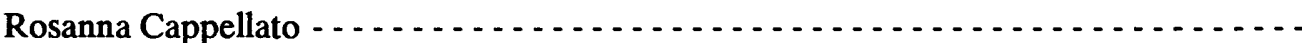

STATISTICAL COMPARISON OF TEMPORAL AND SPATIAL VARIABILITY IN WATER QUALITY AT WELLS IN FIVE LAND-USE AREAS OF NASSAU AND SUFFOLK COUNTIES, LONG ISLAND, NEW YORK

Stephen J. Cauller

DEFINITIONS FOR THE INTERPRETATION OF ANALYTICAL RESULTS FOR RADIONUCLIDES OF ENVIRONMENTAL CONCERN

L. DeWayne Cecil

MEASURING HYDRODGEN CONCENTRATIONS IN GROUND WATER: A TOOL FOR EVALUATING BACTERIAL PROCESSES IN DEEP AQUIFER SYSTEMS

Francis H. Chapelle and Derek R. Lovley

STATISTICAL PROPERTIES OF GROUND-WATER QUALITY DATA

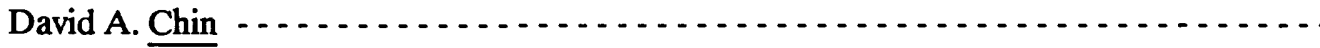

DELINEATION OF FACTORS RELATED TO THE OCCURRENCE OF

1,2-DIBROMOETHANE IN GROUND WATER, CENTRAL FLORIDA

Anne F. Choquette, Brian G. Katz, William S. Pendexter, and Miguel A. Orona

EFFECTS OF ACID PRESERVATION ON THE CONCENTRATIONS OF VOLATILE ORGANIC COMPOUNDS IN NATURAL WATERS

Brooke F. Connor, Mark W. Sandstrom, and Donna Rose $\ldots . . .6 . . .6$

THE AMBIENT GROUND-WATER QUALITY MONITORING PROGRAM OF FLORIDA Rick Copeland $1 . \ldots \ldots \ldots$

GEOCHEMICAL EVOLUTION OF GROUND WATER AT A SURFACE COAL MINE RECLAIMED WITH URBAN SEWAGE SLUDGE IN WESTERN PENNSYLVANIA

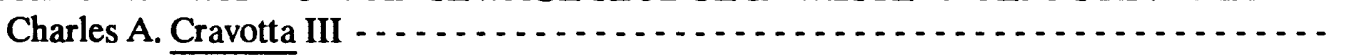

TISSUE-ANALYSIS COMPONENT OF THE NATIONAL WATER-QUALITY ASSESSMENT PROGRAM

J. Kent Crawford 
SELENIUM IN SOILS AND VEGETATION AT THE KENDRICK RECLAMATION PROJECT AREA, WYOMING

James G. Crock, R.C. Severson, and J.A. Erdman $\ldots \ldots \ldots \ldots \ldots$

WESTERN INVESTIGATIONS OF IRRIGATION-INDUCED WATER-QUALITY PROBLEMS

Jonathan P. Deason

THE APPLICATION OF FUGACITY MODELS TO ASSESS CHEMICAL PARTITIONING IN WETLANDS

Joseph J. Delfino and Kathleen J. O'Neil

RESULTS OF BIOLOGICAL UPTAKE TESTS, TOXICITY TESTS AND CHEMICAL ANALYSES OF WATER AND BOTTOM MATERIAL FROM BAYOU D'INDE AND THE LOWER CALCASIEU RIVER, LOUISIANA

Charles R. Demas, Dennis K. Demcheck, Philip Crocker, and George Morrison - . . . . . .

EFFECTS OF AGRICULTURAL PRACTICES ON WATER CHEMISTRY IN AN UNCONFINED COASTAL PLAIN AQUIFER, SUSSEX COUNTY, DELAWARE

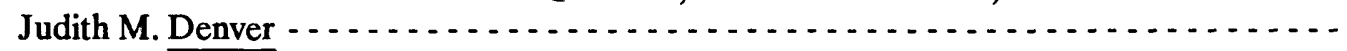

A DISSOLVED OXYGEN BUDGET FOR THE LOWER PATUXENT ESTUARY

D.K. Domotor, M.S. Haire, and N.M. Panday $\ldots \ldots \ldots \ldots$

EXTRACTION OF GASOLINE CONSTITUENTS FROM SOIL

Susan G. Donaldson, Glenn C. Miller, and W.W. Miller _........... 18

NATIONAL PARK SERVICE WATER-QUALITY PROGRAM

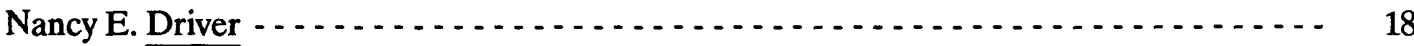

VARIATION IN CONCENTRATIONS OF ATRAZINE AND NITRATE IN GROUND WATER BENEATH AN IRRIGATED CORN FIELD NEAR SHELTON, NEBRASKA

A. Douglas Druliner, Abraham H. Chen, and Dwight Q. Tanner $\ldots \ldots \ldots$

APPLICATION OF THE BATTERY OF TESTS APPROACH AND RANKING SCHEME TO ENVIRONMENTAL SAMPLES

B.J. Dutka -

SIMULATION OF ATRAZINE MOVEMENT IN UNSATURATED MEDIA

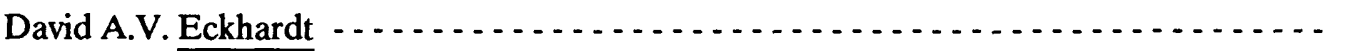

ADSORPTION OF TRICHLOROETHYLENE TO MICROBIAL BIOMASS AND PEAT AT PICATINNY ARSENAL, NEW JERSEY

Theodore A. Ehlke

INTERMETALLIC CONTROLS ON MERCURY PARTITIONING IN BED SEDIMENTS OF NORTHERN WISCONSIN SEEPAGE LAKES

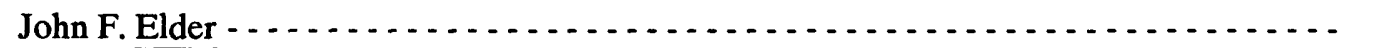

SUGGESTIONS FOR A QUALITY ASSURANCE PROGRAM FOR EVALUATING LABORATORIES

David E. Erdmann - 
EFFECT OF OIL PRODUCTION ACTIVITIES ON SURFACE WATER QUALITY IN THE KENTUCKY RIVER BASIN, KENTUCKY

Ronald D. Evaldi, James L. Smoot, and James A. Kipp . . . . . . . . . . . . . . . . . 22

IMPACT OF AN ARTIFICIAL RECHARGE STRUCTURE ON PESTICIDE CONCENTRATIONS IN THE ADJACENT GROUND WATER

Mary E. Exner $\ldots \ldots \ldots \ldots$

APPLICATIONS OF INDUCTIVELY COUPLED PLASMA MASS SPECTROMETRY TO TRACE ELEMENT ANALYSIS OF NATURAL WATERS

Lynda M. Faires $-\ldots, \ldots \ldots \ldots \ldots \ldots$

EFFECTS OF INDUSTRIAL PUMPING AND RECHARGE ON ADVECTIVE TRANSPORT OF ORGANIC CONTAMINANTS, LONG ISLAND, N.Y.

Steven M. Feldman and Douglas A. Smolensky $\ldots \ldots \ldots$

ADVANCES IN INSTRUMENTATION FOR AUTOMATICALLY MONITORING WATER QUALITY

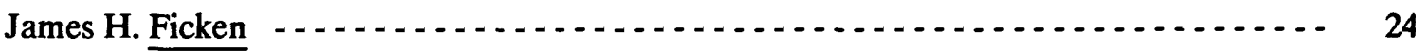

GROUND-WATER FLOW TO SUBSURFACE AGRICULTURAL DRAINS IN THE WESTERN SAN JOAQUIN VALLEY, CALIFORNIA

John Fio and Steven J. Deverel $\ldots \ldots \ldots \ldots$

EFFECT OF STORING DILUTE MERCURY SOLUTIONS IN POLYETHYLENE BOTTLES Marvin J. Fishman, David E. Erdmann, and Jerry V. Farrar _............. 25

EFFECT OF SAMPLE HANDLING ON OBSERVED MERCURY CONCENTRATIONS IN USGS NATIONAL NETWORK SURFACE-WATER SAMPLES, 1973-88

Kathleen K. Fitzgerald $\ldots \ldots \ldots \ldots$

SUPERCRITICAL FLUID EXTRACTION OF TRACE ORGANIC AQUATIC POLLUTANTS PRECONCENTRATED ON SOLID SORBENTS

William T. Foreman

RESPONSE OF AQUATIC COMMUNITIES IN THE BOISE RIVER, IDAHO TO TRACE ELEMENTS IN MUNICIPAL WASTEWATER EFFLUENTS

Steven A. Frenzel

GEOGRAPHICAL DISTRIBUTIONS OF TRACE ELEMENTS IN BOTTOM MATERIAL AND SUSPENDED SEDIMENT IN THE YAKIMA RIVER BASIN, IN CENTRAL WASHINGTON

Gregory J. Fuhrer, Stuart W. McKenzie, Joseph F. Rinella, and Richard F. Sanzolone - - - -

SPECIATION OF SOLUBLE AND ADSORBED SELENIUM IN SOILS, WESTERN SAN JOAQUIN VALLEY, CALIFORNIA

Roger Fujii $\ldots \ldots$

THE BACTERIOLOGICAL QUALITY OF STREAMS IN TROPICAL ISLANDS

Roger S. Fujioka and Johnson Yee 
NONPOINT SOURCE CONTAMINATION OF GROUND WATER IN CENTRAL FLORIDA FROM URBAN RUNOFF, CITRUS CULTIVATION, AND PHOSPHATE MINING

Edward R. German

UNCERTAINTY OF REGRESSION-BASED CONSTITUENT TRANSPORT ESTIMATES

Edward J. Gilroy, Timothy A. Cohn, and Robert M. Hirsch $\ldots \ldots \ldots \ldots \ldots \ldots$

DATA MANAGEMENT, CLEANUP, AND ANALYSIS FOR FLORIDA'S AMBIENT BACKGROUND GROUND WATER MONITORING NETWORK

Tim Glover

SOLID- AND SOLUTE-PHASE TRANSPORT OF ARSENIC IN WHITEWOOD CREEK, SOUTH DAKOTA

Kimball E. Goddard and William R. Roddy -

A RECONNAISSANCE FOR TRIAZINE HERBICIDES IN SURFACE WATERS OF THE UPPER MIDWESTERN UNITED STATES

Donald A. Goolsby, E. Michael Thurman, Dana W. Kolpin, and Mark G. Detroy - . . . . - -

QUALITY OF WATER AND BOTTOM SEDIMENTS ASSOCIATED WITH IRRIGATION DRAINAGE FROM THE ANGOSTURA RECLAMATION UNIT, SOUTHWESTERN SOUTH DAKOTA

Earl A. Greene

EPA'S WATER QUALITY ASSESSMENT PROCESS

Geoffrey H. Grubbs

EPA'S NONPOINT SOURCE PROGRAM

Geoffrey H. Grubbs

ECOLOGICAL ASPECTS OF THE NATIONAL WATER-QUALITY ASSESSMENT PROGRAM

Martin E. Gurtz

EFFECTS OF EXTRACTION PROCEDURES ON ANALYSIS OF WATER FROM CONFINING UNITS IN THE NEW JERSEY COASTAL PLAIN

Mark A. Hardy and Amleto A. Pucci, Jr. $\ldots \ldots \ldots \ldots \ldots \ldots$

PARTITIONING OF ELEMENTS BETWEEN TWO SIZE FRACTIONS IN SEDIMENT SAMPLES FROM THE WESTERN UNITED STATES

Thelma F. Harms, R.C. Severson, and K.C. Stewart

WATER-QUALITY TRENDS OF THE ALBEMARLE-PAMLICO ESTUARINE SYSTEM, NORTH CAROLINA

Douglas A. Harned and Marjorie S. Davenport

TRANSPORT OF BACTERIA THROUGH CONTAMINATED AQUIFER SEDIMENTS IN SMALL-SCALE TRACER EXPERIMENTS: THE ROLE OF SORPTIVE FILTRATION

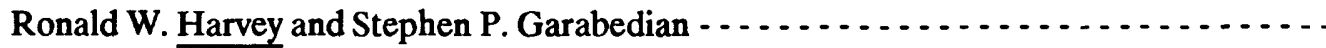


SUPERCRITICAL FLUID EXTRACTION (SFE) AND COUPLED SFE-GC ANALYSIS OF ENVIRONMENTAL SOLIDS AND SORBENT RESINS

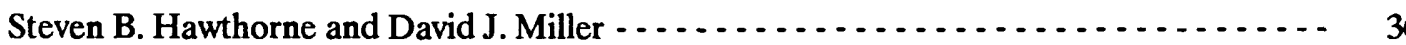

STATISTICAL ANALYSIS OF DATA BELOW DETECTION LIMIT(S)

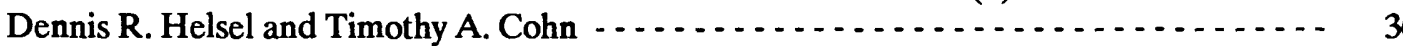

VARIABILITY IN THE CONCENTRATION OF VOLATILE ORGANIC COMPOUNDS DURING WELL PURGING

Beverly H. Herzog, Jacob Gibs, and Thomas E. Imbrigiotta $\ldots \ldots \ldots \ldots$

THE EFFECTS OF LAND-MANAGEMENT PRACTICES ON SURFACE- AND GROUND-WATER QUALITY IN RURAL NORTHEASTERN GUILFORD COUNTY, NORTH CAROLINA

Catherine L. $\underline{\text { Hill }}$

EXTENT OF PESTICIDE CONTAMINATION OF GROUND WATER IN THE UNITED STATES

Patrick W. Holden

A COMPARISON OF RESULTS FROM FIXED-INTERVAL AND STORM-BASED SAMPLING AT A CALIBRATED WATERSHED IN THE GEORGIA PIEDMONT

Richard P. Hooper, Norman E. Peters, and James B. Shanley

MODELING AQUATIC SEDIMENT-ASSOCIATED TRACE ELEMENT

CONCENTRATIONS USING SELECTED GEOCHEMICAL FACTORS

Arthur J. Horowitz, Kent A. Elrick, and Richard P. Hooper $\ldots \ldots \ldots$

SEDIMENT-WATER INTERACTION DURING ARTIFICIAL RECHARGE THROUGH AN ORGANIC MAT

G.F. Huff

HYDROGEOLOGIC CONTROLS ON THE DISTRIBUTION OF RADON-222 IN GROUND WATER OF WEST-CENTRAL NEVADA

Jennifer L. Hughes, Michael S. Lico, and Alan H. Welch $\ldots \ldots \ldots$

GROUND-WATER CHEMISTRY AT THE BUILDING 24 RESEARCH SITE PICATINNY ARSENAL, NORTH-CENTRAL NEW JERSEY

Thomas E. Imbrigiotta and Patrick J. Witkowski $\ldots \ldots \ldots \ldots \ldots \ldots$

CHEMICAL CONTAMINANTS IN THE ENVIRONMENT: ROLE OF THE FISH AND WILDLIFE SERVICE'S ENVIRONMENTAL CONTAMINANTS FIELD OPERATIONS PROGRAM

Gerry Jackson

THE ANAEROBIC BIOREMEDIATION OF TCE CONTAMINATED AQUIFERS:

A FEASIBILITY STUDY

Peter R. Jaffe', Stewart W. Taylor, and Naresh Singhal $\ldots \ldots \ldots \ldots$

A FLOW MODEL BASED ON THE DIFFUSION ANALOGY

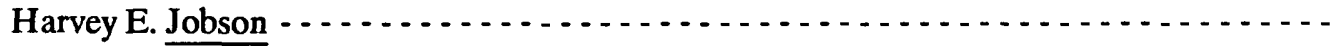


CONTAMINATION OF GROUND AND SURFACE WATER BY AGRICULTURAL

CHEMICALS, BIG SPRING BASIN, CLAYTON COUNTY, IOWA

Stephen J. Kalkhoff

A LONG-TERM PRECIPITATION MONITORING PROGRAM FOR THE UNITED STATES

F. Paul Kapinos

AQUEOUS GEOCHEMISTRY OF THE SAND-AND-GRAVEL AQUIFER AND THE

FLORIDAN AQUIFER SYSTEM, FLORIDA

Brian G. Katz, Anne F. Choquette, and Ruth M. Roaza

STABLE CARBON-ISOTOPE RATIOS AS TRACERS OF SOURCES OF ALKALINITY IN SMALL WATERSHEDS

Carol Kendall

DETECTION OF COLLOIDS BY ULTRAFILTRATION DOWNSTREAM FROM ACID MINE DRAINAGE, UPPER ARKANSAS RIVER, COLORADO

Briant A. Kimball, Gregory A. Wetherbee, E.C. Callender, and Ellen Axtman

TESTING SAMPLING DESIGN METHODS USING THE CAPE COD, MASSACHUSETTS TRACER TEST DATA AND ONE-DIMENSIONAL TRANSPORT MODELS

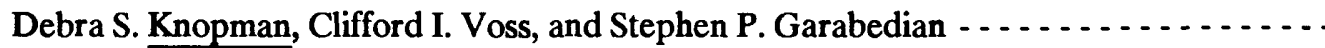

INDICATORS OF PESTICIDES IN SHALLOW AQUIFERS IN IOWA

Dana W. Kolpin and Michael R. Burkart $\ldots \ldots \ldots \ldots$

EVALUATING NONPOINT-SOURCE CONTAMINANTS IN THE CONESTOGA

HEADWATERS, PENNSYLVANIA

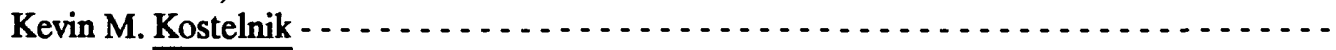

RADIUM IN THE LOWER MISSISSIPPI RIVER

T.F. Kraemer

WATER QUALITY INVESTIGATIONS IN THE U.S. VIRGIN ISLANDS

J. Hari Krishna and Robert H. Ruskin

MODIFICATION OF THE QUAL2E WATER-QUALITY MODEL FOR APPLICATION TO SMALL FOOTHILL STREAMS NEAR PIKES PEAK, COLORADO

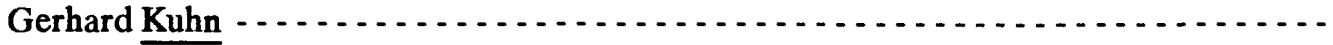

HYDROLOGIC AND GEOLOGIC FACTORS AFFECTING THE SHAPE OF A SEWAGE PLUME ON CAPE COD, MASSACHUSETTS

Denis R. LeBlanc

DETERMINATION OF THE EXTENT OF GASOLINE CONTAMINATION OF A SHALLOW SAND AQUIFER USING SOIL GAS ANALYSES FOR VOLATILE ORGANIC COMPOUNDS IN JACKSON, TENNESSEE

Roger W. Lee 
POLYETHYLENE-GLYCOL RESIDUES FROM NONIONIC SURFACTANTS IN THE LOWER MISSISSIPPI RIVER

J.A. Leenheer, R.L. Wershaw, P.A. Brown, and T.I. Noyes $\ldots \ldots \ldots \ldots$

A RECONNAISSANCE STUDY OF THE DISTRIBUTION OF HALOGENATED ORGANIC COMPOUNDS IN CATFISH FROM THE LOWER MISSISSIPPI RIVER AND ITS TRIBUTARIES

Thomas J. Leiker, Wilfred E. Pereira, Colleen E. Rostad, and Charles Barnes - . . . . - .

THE ANALYSIS OF ENVIRONMENTAL FACTORS CONTROLLING THE SPECIES COMPOSITION OF BENTHIC COMMUNITIES

Harry V. Leland and Steven V. Fend $\ldots \ldots \ldots \ldots$

ROLE OF MODELS IN ADDRESSING AGRICULTURAL MANAGEMENT AND WATER QUALITY

Ralph A. Leonard

GEOCHEMISTRY OF GROUND WATER AT AND NEAR FERNLEY WILDLIFE

MANAGEMENT AREA, LYON COUNTY, NEVADA

Michael S. Lico

RAPID DETECTION OF HUMAN ENTEROVIRUSES RECOVERED FROM WATER BY THE NITROCELLULOSE-ENZYME IMMUNOASSAY (NC-EIA) AND ITS AMPLIFICATION BY STREPTAVIDIN-BIOTIN (SAB)

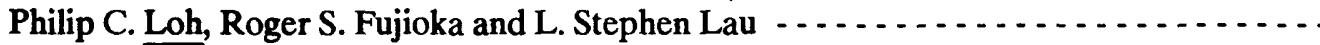

STATISTICAL APPLICATIONS USED IN THE U.S. GEOLOGICAL SURVEY'S EVALUATION PROGRAM FOR STANDARD REFERENCE SAMPLES

H. Keith Long

OXIDATION OF AROMATIC CONTAMINANTS COUPLED TO MICROBIAL REDUCTION OF IRON

Derek R. Lovley, Debra J. Lonergan, Elizabeth J.P. Phillips, and Isabelle M. Cozzarelli - . -

MICROBIALLY CATALYZED REDUCTION OF IRON AND MANGANESE

Derek R. Lovley and Elizabeth J.P. Phillips

RETRIEVAL AND ANALYSIS OF THE RESULTS FROM THE BLIND SAMPLE QUALITY-ASSURANCE PROGRAM AT THE NATIONAL WATER QUALITY LABORATORY OF THE U.S. GEOLOGICAL SURVEY

Keith J. Lucey

RESULTS FOR MERCURY IN THE BLIND SAMPLE QUALITY-ASSURANCE PROGRAM OF THE U.S. GEOLOGICAL SURVEY

Keith J. Lucey and David E. Erdmann $\ldots \ldots \ldots \ldots$

USE OF DEUTERIUM AND OXYGEN-18 TO TRACE THE INDUCED INFILTRATION OF DELAWARE RIVER WATER INTO THE POTOMAC-RARITAN-MAGOTHY AQUIFER SYSTEM, CAMDEN AREA, NEW JERSEY

Steven D. McAuley and Carol Kendall 
DISSOLVED OXYGEN TRENDS IN THE TRINITY RIVER, TEXAS

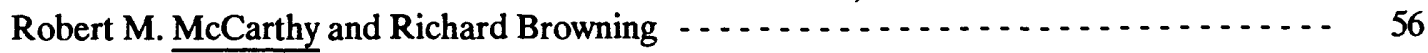

EFFECT OF INJURY INDUCED BY AQUATIC STRESS ON INDICATOR AND ENTERIC PATHOGENIC BACTERIA

Gordon A. McFeters and Ajaib Singh $\ldots \ldots \ldots \ldots \ldots$

URANIUM-SERIES RADIONUCLIDES IN THE MISSISSIPPI RIVER

Brent A. McKee $\ldots \ldots \ldots \ldots \ldots$

GROUNDWATER PROTECTION PROGRAMS IN ILLINOIS: APPLICATION OF

GEOLOGIC MAPPING AND BASIC HYDROGEOLOGIC PRINCIPLES

Dennis P. McKenna, Richard C. Berg, and John P. Kempton . . . . . . . . . . .

PHYTOPLANKTON DYNAMICS IN ROCKY MOUNTAIN LAKES AND POTENTIAL

RESPONSE TO CHANGES IN LAKEWATER CHEMISTRY

Diane M. McKnight, Richard Smith, J. Platt Bradbury, Jill Baron, and Sarah Spaulding - . -

THE PRODUCTION AND CARBON ISOTOPIC COMPOSITION OF BACTERIAL $\mathrm{CO}_{2}$ IN DEEP COASTAL PLAIN SEDIMENTS OF SOUTH CAROLINA

Peter B. McMahon and Douglas F. Williams

THE EFFECTS OF FRESHWATER INFLOW ON THE PHYTOPLANKTON CARBON-14

PRODUCTIVITY AND CHLOROPHYLL-A IN THE CHARLOTTE HARBOR

ESTUARINE SYSTEM, SOUTHWESTERN FLORIDA

Benjamin F. McPherson and Ralph T. Montgomery $\ldots \ldots \ldots$

SAMPLING STRATEGIES AND PROCEDURES FOR TRACKING TOXIC CHEMICALS

THROUGH LARGE RIVER SYSTEMS SUCH AS THE MISSISSIPPI RIVER

Robert H. Meade

USE OF DNA (DEOXYRIBONUCLEIC ACID) AND TANC (TOTAL ADENYLATE

NUCLEOTIDE CONTENT) MEASUREMENTS FOR DELINEATING MICROBIAL

ACTIVITY AND ESTIMATION OF BIOMASS IN AN ORGANICALLY

CONTAMINATED AQUIFER

David W. Metge, Ronald W. Harvey, Myron H. Brooks, and Richard L. Smith . . . . . . . .

CONCENTRATING SUSPENDED SEDIMENT FOR ORGANIC ANALYSIS

Michael Meyer, E.M. Thurman, and Robert Bannister $\ldots . . . \ldots \ldots$

SORPTION AND DESORTPION OF HYDROPHOBIC ORGANIC CONTAMINANTS IN SATURATED GROUNDWATER SYSTEMS

C.T. Miller and J.A. Pedit $\ldots \ldots \ldots \ldots \ldots$

LOW-LEVEL NUTRIENT ANALYSIS OF NATURAL-WATER SAMPLES USING A RAPID-FLOW ANALYZER

Donna L. Milne, Merle Shockey, Tom Bushly, and Carl Harris

DISCHARGE-WEIGHTED PUMPING METHOD FOR COLLECTING THE FINE FRACTION OF SUSPENDED SEDIMENT

John A. Moody 
ACCUMULATION OF ORGANOCHLORINE PESTICIDE AND PCB RESIDUES IN THE SEDIMENTS OF ICEDALE LAKE, CHESTER COUNTY, PENNSYLVANIA

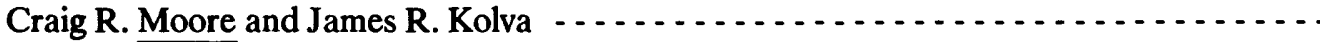

EFFECTIVENESS OF AQUIFERS IN THE DILUTION OF NONPOINT SOURCE LOW MCL CONTAMINANTS

W. Bruce Moore and Honesto Roaza $\ldots \ldots \ldots$

THE CAPACITY OF A BOTTOMLAND-HARDWOOD WETLAND TO MODIFY THE

CHEMICAL AND SEDIMENT COMPOSITION OF AN ADJACENT RIVERINE SYSTEM

E.E. Morris, Barbara A. Kleiss, and Dr. Joseph F. Nix $\ldots \ldots \ldots$

TOXICITY OF SEDIMENTS, EFFLUENTS AND RECEIVING WATERS OF THE LOWER CALCASIEU RIVER, LOUISIANA

George Morrison, Elise Torello, and Michele Redmond

NATIONAL WATER CLEANUP UNDER THE CLEAN WATER ACT 1976-89

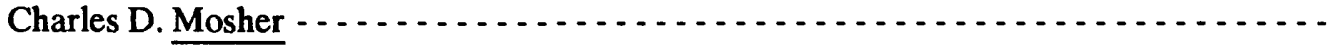

OCCURRENCE AND VARIABILITY OF ESCHERICHLA COLI AND FECAL-COLIFORM DENSITIES IN THE OLENTANGY AND SCIOTO RIVERS IN THE COLUMBUS, OHIO, AREA

Donna N. Myers

GLACIAL-ICE GEOCHEMISTRY, KNIFE POINT GLACIER, WIND RIVER RANGE, WYOMING - RECONNAISSANCE-PHASE RESULTS

David L. Naftz, Howard E. Taylor, James A. Rice, and James R. Ranville . . . . . . . . . . . .

COMPARATIVE BIOCONCENTRATION OF SELENATE AND SELENITE BY BLUEGILL (LEPOMIS MACROCHIRUS) AND FATHEAD MINNOWS (PIMEPHALES PROMELAS)

Richard S. Ogle and Allen W. Knight $\ldots \ldots \ldots \ldots \ldots$

A RAPID SCREENING METHOD FOR ESTIMATING ATRAZINE AND ITS METABOLITES IN NATURAL WATER SAMPLES

M.G. Ondrus and T.R. Steinheimer $\ldots \ldots \ldots \ldots$

IS WATER A RELEVANT SAMPLING MEDIUM FOR TOXIC CHEMICALS? AN ALTERNATIVE ENVIRONMENTAL SENSING STRATEGY

Edwin D. Ongley, D.A. Birkholz, J.H. Carey, and M.R. Samoiloff

DEVELOPMENT AND EVALUATION OF AN APPROACH INTEGRATING AN

OPTIMIZATION MODEL AND AN EXPERT SYSTEM FOR IDENTIFYING UNKNOWN GROUNDWATER POLLUTION SOURCES

Gerald T. Orlob, M. Levent Kavvas, Jean E. Beegle, and Bithin Datta . . . . . . . . . . .

THE TRINITY RIVER, TEXAS: A CASE STUDY OF THE LIMITS OF WASTE-LOAD ALLOCATION

James Patek, George Ward, and Robert McCarthy 
MONITORING SALTWATER INTRUSION IN SOUTH CAROLINA RIVERS

Glenn G. Patterson, Rodney N. Cherry, C.L. Sanders, Jr., Larry R. Bohman, and

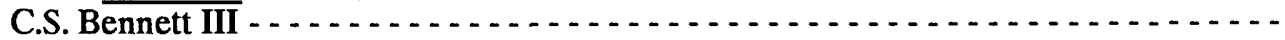

ACCURACY OF USGS MINIMONITOR MEASUREMENTS IN LOW SOLUTE CONTENT STREAMS

D.V. Peck, M.A. Stapanian, R.C. Metcalf, and D.T. Heggem $\ldots \ldots \ldots$

DEPRESSED REDOX POTENTIAL TO ENHANCE MICROBIAL DECHLORINATION OF PCBS

Stephen F. Pedersen and Ronald D. Neufeld $\ldots \ldots \ldots \ldots \ldots$

OCCURRENCE, DISTRIBUTION, TRANSPORT AND FATE OF SYNTHETIC ORGANIC CONTAMINANTS IN THE LOWER MISSISSIPPI RIVER AND ITS MAJOR TRIBUTARIES

W.E. Pereira, C.E. Rostad, and T.J. Leiker $\ldots \ldots \ldots$

EXPERIMENTAL SURFACE-WATER SAMPLING DEVICE FOR AGRICULTURAL FIELD-RUNOFF INVESTIGATIONS

Charles A. Perry and E.M. Thurman $\ldots \ldots \ldots$

GEOCHEMICAL PROCESSES AFFECTING STREAMWATER SOLUTE COMPOSITION AND TRANSPORT IN A FORESTED PIEDMONT WATERSHED

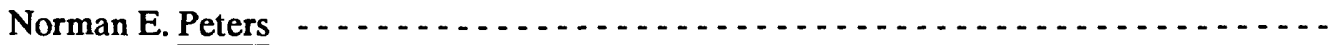

ANALYSIS OF TOTAL NITROGEN IN NATURAL WATER SAMPLES USING

PYROCHEMILUMINESCENCE -- A SMALL VOLUME, ACID-FREE TECHNIQUE

Linda K. Pratt and Merle W. Shockey $\ldots \ldots \ldots \ldots \ldots$

WATER QUALITY INDEX SYSTEM OF THE BRAZOS RIVER AUTHORITY

Philip W. Price

ASSURING DATA QUALITY AT THE U.S. GEOLOGICAL SURVEY NATIONAL WATER QUALITY LABORATORY

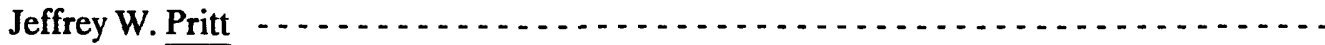

QUALITY ASSURANCE OF SAMPLE CONTAINERS AND PRESERVATIVES AT THE

U.S. GEOLOGICAL SURVEY NATIONAL WATER QUALITY LABORATORY

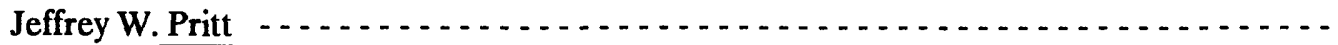

WATER-CHEMISTRY AND BIOLOGICAL RECONNAISSANCE OF CORE MATERIAL FROM HYDROGEOLOGIC UNITS IN THE COASTAL PLAIN OF NEW JERSEY

Amleto A. Pucci, Jr., Ted Ehlke, and James P. Owens - . . . . . . . . . . . . . . . .

PRECIPITATION AND STREAM-WATER CHEMISTRY IN NORTH-CENTRAL MARYLAND

Karen C. Rice and Owen P. Bricker

COMPARISON OF ANALYTICAL APPROACHES FOR ASSESSING TRACE-ORGANIC COMPOUNDS IN THE YAKIMA RIVER BASIN, WASHINGTON 
THE NATIONAL STATUS AND TRENDS PROGRAM FOR MARINE ENVIRONMENTAL QUALITY: MONITORING TOXIC CONTAMINATION IN U.S. COASTAL WATERS

Andrew Robertson -

PREDICTION OF WATER QUALITY THROUGH GEOCHEMICAL MODELING IN UNDEVELOPED AREAS IN THE DESERT SOUTHWEST

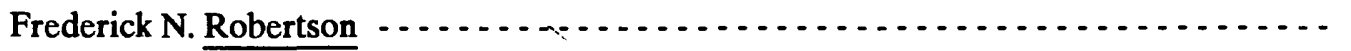

ESTIMATING HISTORICAL RIVER POLLUTION TRENDS USING MASS BALANCE PRINCIPLES: SELECTED METALS IN THE HUDSON-RARITAN BASIN, 1880 TO 1980

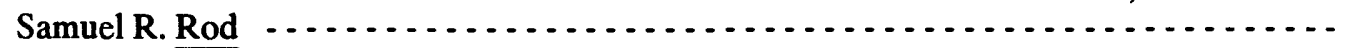

IDENTIFICATION OF ORGANIC CONTAMINANTS BY GAS

CHROMATOGRAPHY/HIGH-RESOLUTION MASS SPECTROMETRY

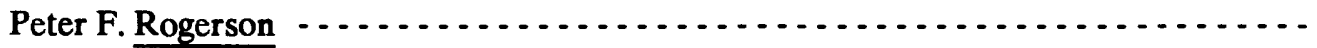

DETERMINATION OF HALOGENATED ORGANIC COMPOUNDS IN MISSISSIPPI RIVER SUSPENDED SEDIMENT BY NEGATIVE ION CHEMICAL IONIZATION MASS SPECTROMETRY

C.E. Rostad, W.E. Pereira, and T.J. Leiker

MERCURY AND SELENIUM CONCENTRATIONS IN SURFACE WATER, BOTTOM SEDIMENT, AND BIOTA, STILLWATER WILDLIFE MANAGEMENT AREA AND VICINITY, CHURCHILL COUNTY, NEVADA

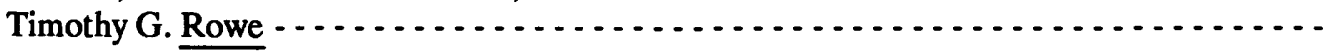

RELATIONS BETWEEN FISH POPULATIONS AND WATER QUALITY IN THE UPPER ILLINOIS RIVER BASIN IN ILLINOIS, INDIANA, AND WISCONSIN: ANALYSIS OF EXISTING INFORMATION

Peter M. Ruhl and Robert G. Striegl

TRANSPORT OF CHLORIDE AND ATRAZINE THROUGH THE UNSATURATED ZONE BENEATH TWO IRRIGATED FIELDS IN SOUTH-CENTRAL KANSAS

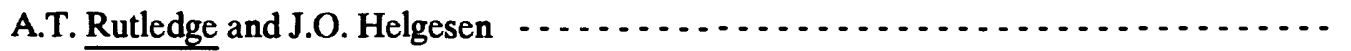

INVESTIGATION OF THE STRUCTURAL FEATURES AND INTERACTIONS OF AQUATIC FULVIC ACIDS IN SURFACE AND GROUNDWATER

Farida Y. Saleh, Wenching Ong, Inyoung Kim, and Qasem Haj-Mahmoud

FIELD METHOD FOR SOLID-PHASE EXTRACTION OF HERBICIDES IN SURFACE AND GROUND WATER

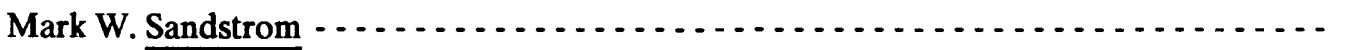

TREND ANALYSIS OF TEXAS WATER-QUALITY DATA

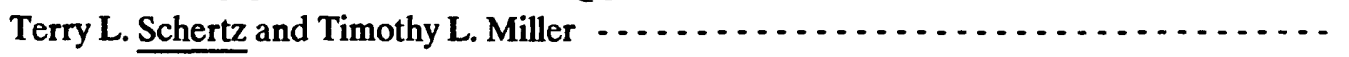

ALTERNATIVES TO THE MEASUREMENT OF TISSUE CONCENTRATIONS FOR DOCUMENTING EXPOSURE TO AND EFFECTS OF CONTAMINANTS IN FISH

Christopher J. Schmitt and Bryan L. Steadman 
A CONSTITUENT IDENTIFIER SYSTEM FOR THE NATIONAL WATER INFORMATION SYSTEM (NWIS-II)

James C. Schornick $\ldots \ldots \ldots$

IDENTIFICATION OF THE DIFFERENCES BETWEEN ONSITE AND LABORATORY $\mathrm{pH}$ DETERMINATIONS USING A QUALITY-ASSURANCE PROGRAM

LeRoy J. Schroder, Randolph B. See, and Timothy C. Willoughby . . . . . . . . . . . .

CONTROLS ON DRAINWATER COMPOSITION IN THE IMPERIAL VALLEY, CALIFORNIA

Roy A. Schroeder, James G. Setmire, and Jill N. Densmore $\ldots \ldots$

ANALYSIS OF ORGANIC CONTAMINANTS AT THE NATIONAL WATER QUALITY LABORATORY OF THE U.S. GEOLOGICAL SURVEY II. METHODOLOGICAL IMPROVEMENTS IN SEDIMENT ANALYSES

Peter Schulmeyer and Edward T. Furlong

UTILITY AND LIMITATIONS OF IMMUNOASSAY TESTS AS A FIELD SCREENING METHOD FOR TRIAZINE HERBICIDES

Peter A. Schulze and Paul D. Capel $\ldots \ldots \ldots$

QUALITY-ASSURANCE PROGRAM FOR A PRECIPITATION-MONITORING NETWORK

R.B. See, B.A. Malo, LJ. Schroder, and T.C. Willoughby

CHLOROFLUOROCARBON COMPOUNDS IN GROUND WATER: A POSSIBLE MANAGEMENT TOOL

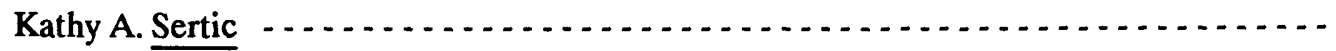

FACTORS CONTROLLING AQUEOUS SULFATE CONCENTRATIONS AT PANOLA MOUNTAIN, GEORGIA

James B. Shanley, Norman E. Peters, and Richard P. Hooper

STRATEGY FOR GROUND-WATER QUALITY ASSESSMENT OF THE DELMARVA PENINSULA, DELAWARE, MARYLAND, AND VIRGINIA

Robert J. Shedlock, Patrick J. Phillips, L. Joseph Bachman, and Pixie A. Hamilton . . . . . .

IMPROVED SAMPLING METHODS FOR ORGANIC CONSTITUENTS

Larry R. Shelton

THE ROLE OF SUBMARINE GROUNDWATER DISCHARGE TO NUTRIENT FLUX IN COASTAL AND OCEANIC ENVIRONMENTS

George M. Simmons, Jr.

THE RELATION OF TOXICITY-TEST RESULTS TO PHASE ASSOCIATION AND CONCENTRATION OF CHROMIUM, MANGANESE, IRON AND AMMONIUM IN THE WATER COLUMN AND SEDIMENTS OF AN INDUSTRIALLY AFFECTED AREA OF THE CALCASIEU RIVER, LOUISIANA

N.S. Simon 
RELATING GROUND-WATER QUALITY TO LAND USE: CONSIDERATIONS OF SCALE AND DATA RESOLUTION

Steven F. Siwiec and Paul E. Stackelberg

INVERTEBRATE DRIFT AS A BIOLOGICAL INDICATOR OF WATER QUALITY

Keith V. Slack, Larry J. Tilley, and Susan S. Kennelly $\ldots \ldots \ldots \ldots$

APPLICATION OF GEOGRAPHIC INFORMATION SYSTEMS TO STATEWIDE WATER-QUALITY ASSESSMENT

R.A. Smith, R.B. Alexander, K.W. Robinson, C.V. Price, D.A. White, K.F. Lins, and

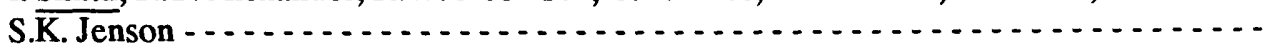

USE OF MULTIVARIATE TECHNIQUES FOR BACKGROUND AND ANTHROPOGENIC-SOURCE ANALYSIS OF TRACE ELEMENTS IN STREAMBED MATERIALS IN THE UPPER ILLINOIS RIVER BASIN IN ILLINOIS, INDIANA, AND WISCONSIN

Steven M. Smith, Richard F. Sanzolone, and John A. Colman $\ldots \ldots \ldots \ldots$

EFFECT OF FLOW CONDITIONS ON STREAM REAERATION COEFFICIENTS

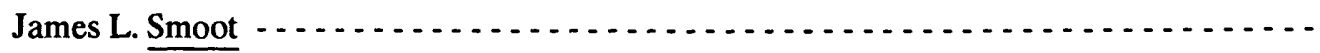

DEPARTMENT OF INTERIOR IRRIGATION DRAINAGE PROGRAM

RECONNAISSANCE STUDY OF KLAMATH BASIN REFUGE AREAS, CALIFORNIA AND OREGON

Stephen K. Sorenson and S.E. Schwarzbach

TRANSPORT OF ORGANIC CONTAMINANTS IN GROUND WATER BENEATH AN ABANDONED OIL REFINERY

Timothy B. Spruill

HERBICIDES IN SURFACE AND GROUND WATER, CEDAR RIVER BASIN, IOWA AND MINNESOTA

Paul J. Squillace, Mark W. Sandstrom, and Wilfred E. Pereira $\ldots . . . \ldots \ldots \ldots$

SETTLING PROPERTIES OF SUSPENDED SEDIMENT FROM THE MISSISSIPPI RIVER

Robert F. Stallard and Deborah A. Martin $\ldots . . \ldots \ldots \ldots \ldots$

USING A GEOGRAPHIC INFORMATION SYSTEM TO RELATE HUMAN AND NATURAL FACTORS TO STREAM WATER QUALITY IN THE UPPER ILLINOIS RIVER BASIN IN ILLINOIS, INDIANA, AND WISCONSIN

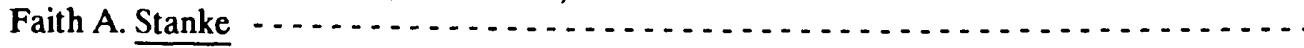

SIMULATION OF THE CHEMICAL EVOLUTION OF A PLUME OF ACIDIC GROUND WATER

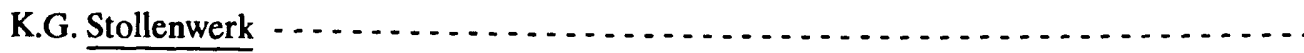

DEVELOPMENT OF SURFACE WATER QUALITY STANDARDS FOR TOXIC SUBSTANCES "THE WISCONSIN EXPERIENCE"

John R. Sullivan - 
RESULT OF A WATER QUALITY MONITORING AND MODELING PROGRAM FOR THE PATUXENT RIVER BASIN, MARYLAND

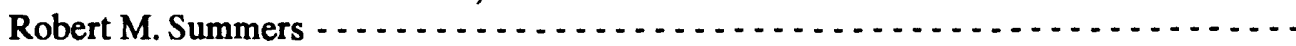

POTENTIAL USE OF CONSTRUCTED WETLANDS TO TREAT LANDFILL LEACHATE

Jan M. Surface, Tammo S. Steenhuis, William E. Sanford, John H. Peverly, Robert J. Kopka, and Mitchell J. Lavine

EVALUATION OF A MODIFIED COMMERCIAL AUTOMATIC SAMPLER FOR THE COLLECTION OF WATER SAMPLES CONTAINING TRACE ORGANICS

D.Y. Tai, Marshall E. Jennings, Kevin D. White, and L.A. Garcia . . . . . . . . . . . . .

OCCURRENCE AND DISTRIBUTION OF TRACE METALS IN THE MISSISSIPPI RIVER

Howard E. Taylor, John R. Garbarino, and Terry I. Brinton $\ldots \ldots \ldots \ldots \ldots$

BIOLOGICAL MONITORING OF STREAMS IN JEFFERSON COUNTY, KENTUCKY

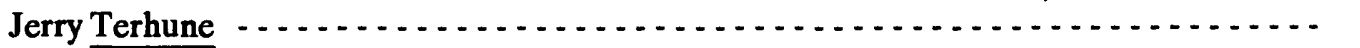

OCCURRENCE AND DISTRIBUTION OF NUTRIENTS AND DISSOLVED OXYGEN IN

THE UPPER ILLINOIS RIVER BASIN IN ILLINOIS, INDIANA, AND WISCONSIN:

RESULTS OF A 1988 LOW-FLOW SYNOPTIC SURVEY

Paul J. Terrio

ENHANCEMENT OF A HYDROLOGIC BENCH-MARK NETWORK SITE

John T. Turk

101

SOURCES OF ERROR IN FIELD SPECIFIC-CONDUCTANCE MEASUREMENTS

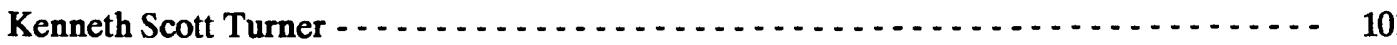

ATTENUATION OF NITROGEN AND FECAL COLIFORMS FROM SEPTIC-TANK EFFLUENT THROUGH A THICK UNSATURATED ZONE, UPPER MOJAVE RIVER BASIN, CALIFORNIA

Amjad M.J. Umari, Peter Martin and Roy A. Schroeder

GEOCHEMICAL CONTROLS ON RADIONUCLIDE MOBILITY IN SHALLOW GROUND WATER NEAR AN EPHEMERAL STREAM IN NORTHEASTERN ARIZONA

P.C. Van Metre, Laurie Wirt, and J.R. Gray $\ldots \ldots \ldots$

STATISTICAL ANALYSIS OF WATER QUALITY OF STORMFLOW AND BASE FLOW FOR STREAMS IN THE AUSTIN AREA, TEXAS

Jack E. Veenhuis

APPLIED RESEARCH USING CHLORINE-36 AS A HYDROGEOLOGIC TOOL

G. Vourvopoulos, J.V. Brahana, T.F. Kraemer, W. Wolfli, M. Suter, and A. Syna

RESEARCH PLAN TO EVALUATE THE RELATIONS AMONG GROUND-WATER QUALITY, HYDROGEOLOGIC CONDITIONS, AND HUMAN ACTIVITIES IN THE NORTHERN ATLANTIC COASTAL PLAIN

Eric F. Vowinkel and Steven F. Siwiec 
DELINEATION OF CONTAMINATED GROUND-WATER DISCHARGE ZONES USING ANALYSIS OF BOTTOM-SEDIMENT METHANE BUBBLES, CANAL CREEK, MARYLAND

Don A. Vroblesky and Michelle M. Lorah $\ldots \ldots \ldots \ldots$

SUMMARY OF EPA'S PESTICIDES IN GROUND WATER STRATEGY

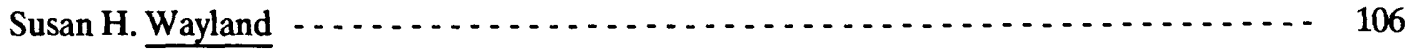

CONSIDERATIONS IN INTERPRETING MERCURY CONCENTRATIONS IN WATER SAMPLES COLLECTED BY THE U.S. GEOLOGICAL SURVEY

Wayne E. Webb $\ldots \ldots \ldots \ldots$

CHEMISTRY OF SNOWPACK AND GROUND WATER IN THE VICINITY OF TWO NORTHWESTERN WISCONSIN SEEPAGE LAKES

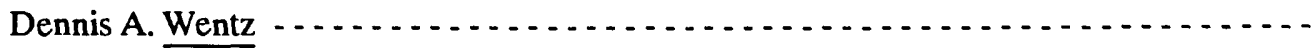

ANALYSIS OF VARIANCE IN THE SAMPLING OF STREAMBED MATERIALS FOR ANTHROPOGENIC ORGANIC COMPOUNDS

Kevin D. White 107

RELATION OF STORM-WATER PERCOLATE TO GROUND-WATER QUALITY AT THREE STORM-WATER-MANAGEMENT FACILITIES IN MARYLAND

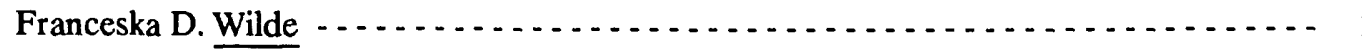

DISTRIBUTION OF TRACE METALS IN SEDIMENT AT PICATINNY ARSENAL, NEW JERSEY

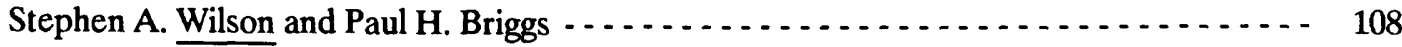

OCCURRENCE AND MOVEMENT OF RADIONUCLIDES IN THE PUERCO RIVER BASIN, ARIZONA AND NEW MEXICO

Laurie Wirt, J.R. Gray, and P.C. Van Metre . . . . . . . . . . . . . . . . . . . . . . . . . . 109

PRIMARY PRODUCTION OF BIG LAKE, SOUTH-CENTRAL ALASKA

Paul F. Woods

BOTANICAL COMMENTS ON TREES AS CHEMICAL RECORDERS OF GROUND-WATER CONTAMINATION

Thomas M. Yanosky and Don A. Vroblesky ... . . . . . . . . . . . . . . . . 110

IMPROVING SENSITIVITY AND CONTROLLING ENHANCEMENT EFFECTS IN DIRECT CURRENT PLASMA OPTICAL EMISSION SPECTROSCOPY

Edward J. Zayhowski and Mark R. Hill

SOURCES AND MAGNITUDE OF ERROR ASSOCIATED WITH VARIOUS TECHNIQUES OF ESTIMATING NUTRIENT AND SUSPENDED-SEDIMENT LOADS FROM THE SUSOUEHANNA RIVER BASIN TO THE CHESAPEAKE BAY

Linda D. Zynjuk, Robert M. Summers, and Timothy A. Cohn 


\section{PROGRAM}

Monday, November 13, 1989

\section{PLENARY SESSION}

Page

9:00 WELCOME. - James L. Cook, U.S. Geological Survey

9:15 KEYNOTE SPEAKER. - Philip Cohen

FUTURE OF WATER-QUALITY PROGRAMS IN THE U.S. GEOLOGICAL

SURVEY

Philip Cohen, U.S. Geological Survey

10:00 INVITED SPEAKER. - Susan H. Wayland

SUMMARY OF EPA'S PESTICIDES IN GROUND WATER STRATEGY

Susan H. Wayland, U.S. Environmental Protection Agency _... . . . . . 106

10:30 INVITED SPEAKER. - C.R. Amerman

PRESIDENT'S INITIATIVE ON ENHANCING WATER QUALITY

C.R. Amerman, U.S. Department of Agriculture

11:00 INVITED SPEAKER. - Andrew Robertson

THE NATIONAL STATUS AND TRENDS PROGRAM FOR MARINE

ENVIRONMENTAL QUALITY: MONITORING TOXIC CONTAMINATION

IN U.S. COASTAL WATERS

Andrew Robertson, National Oceanic and Atmospheric Administration - . . . . . 77

CONCURRENT SESSIONS

Monday Aftemoon, November 13, 1:00-2:40

SESSION 1

Water Quality Models

1:00 INVITED SPEAKER

ROLE OF MODELS IN ADDRESSING AGRICULTURAL MANAGEMENT AND

WATER QUALITY

Ralph A. Leonard, U.S. Department of Agriculture

1:20 PREDICTION OF WATER QUALITY THROUGH GEOCHEMICAL MODELING

IN UNDEVELOPED AREAS IN THE DESERT SOUTHWEST

Frederick N. Robertson, U.S. Geological Survey - . . . . . . . . . . . . . . 77

1:40 A COMPUTERIZED SYSTEM FOR THE DETECTION AND ANALYSIS OF

LONG-TERM TRENDS IN WATER-QUALITY DATA

Richard B. Alexander*, Terry L. Schertz, and Dane J. Ohe, U.S. Geological

Survey $\ldots \ldots \ldots \ldots$

2:00 A DISSOLVED OXYGEN BUDGET FOR THE LOWER PATUXENT ESTUARY

D.K. Domotor*, M.S. Haire, and N.M. Panday, Maryland Department of the Environment

2:20 A FLOW MODEL BASED ON THE DIFFUSION ANALOGY

Harvey E. Jobson, U.S. Geological Survey $\ldots \ldots \ldots \ldots$

*Presenting author 


\section{SESSION 2}

\section{Organics in Ground Water}

Page

1:00 DELINEATION OF CONTAMINATED GROUND-WATER DISCHARGE ZONES USING ANALYSIS OF BOTTOM-SEDIMENT METHANE BUBBLES, CANAL CREEK, MARYLAND

Don A. Vroblesky* and Michelle M. Lorah, U.S. Geological Survey - . . . . . . . . 105

1:20 EFFECTS OF INDUSTRIAL PUMPING AND RECHARGE ON ADVECTIVE TRANSPORT OF ORGANIC CONTAMINANTS, LONG ISLAND, N.Y. Steven M. Feldman* and Douglas A. Smolensky, U.S. Geological Survey … . . . . 24

1:40 CHLOROFLUOROCARBON COMPOUNDS IN GROUND WATER: A POSSIBLE MANAGEMENT TOOL

Kathy A. Sertic, U.S. Geological Survey $\ldots \ldots \ldots$. . . . . . . . . . . . . . . 87

2:00 HYDROCARBON CONTAMINATION WITHIN THE UPPER FLORIDAN AQUIFER IN ORLANDO, FLORIDA

L. A. Bradner, U.S. Geological Survey

2:20 INVESTIGATION OF THE STRUCTURAL FEATURES AND INTERACTIONS

OF AQUATIC FULVIC ACIDS IN SURFACE AND GROUNDWATER

Farida Y. Saleh*, Wenching Ong, Inyoung Kim, and Qasem Haj-Mahmoud,

University of North Texas

\section{SESSION 3}

Analysis of Water Quality Data

1:00 STATISTICAL ANALYSIS OF DATA BELOW DETECTION LIMIT(S)

Dennis R. Helsel* and Timothy A. Cohn, U.S. Geological Survey $\ldots \ldots \ldots \ldots$

1:20 UNCERTAINTY OF REGRESSION-BASED CONSTITUENT TRANSPORT ESTIMATES

Edward J. Gilroy*, Timothy A. Cohn, and Robert M. Hirsch, U.S. Geological Survey

SOURCES AND MAGNITUDE OF ERROR ASSOCIATED WITH VARIOUS

TECHNIQUES OF ESTIMATING NUTRIENT AND SUSPENDED-SEDIMENT

LOADS FROM THE SUSQUEHANNA RIVER BASIN TO THE CHESAPEAKE

BAY

Linda D. Zynjuk*, U.S. Geological Survey, Robert M. Summers, Maryland Department of the Environment, and Timothy A. Cohn, U.S. Geological Survey . . . . .

2:00 STATISTICAL PROPERTIES OF GROUND-WATER QUALITY DATA

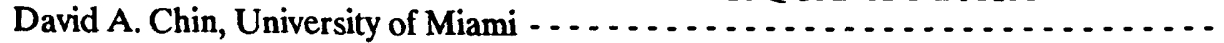

2:20 DEFINITIONS FOR THE INTERPRETATION OF ANALYTICAL RESULTS FOR RADIONUCLIDES OF ENVIRONMENTAL CONCERN

L. DeWayne Cecil, U.S. Geological Survey

\section{CONCURRENT SESSIONS \\ Monday Aftemoon, November 13, 3:10-4:50}

SESSION 4

Water Quality Models

3:10 RELATING GROUND-WATER QUALITY TO LAND USE: CONSIDERATIONS OF SCALE AND DATA RESOLUTION

Steven F. Siwiec* and Paul E. Stackelberg, U.S. Geological Survey 
3:30 SIMULATION OF ATRAZINE MOVEMENT IN UNSATURATED MEDIA

David A.V. Eckhardt, U.S. Geological Survey $\ldots \ldots \ldots \ldots$

3:50 DEVELOPMENT AND EVALUATION OF AN APPROACH INTEGRATING AN OPTIMIZATION MODEL AND AN EXPERT SYSTEM FOR IDENTIFYING UNKNOWN GROUNDWATER POLLUTION SOURCES

Gerald T. Orlob*, M. Levent Kavvas, Jean E. Beegle, and Bithin Datta, University of California Davis -- Uevent Kavwas, Jean E. Beegle, and Bithin Datta, University

4:10 TESTING SAMPLING DESIGN METHODS USING THE CAPE COD,

MASSACHUSETTS TRACER TEST DATA AND ONE-DIMENSIONAL

TRANSPORT MODELS

Debra S. Knopman*, Clifford I. Voss, and Stephen P. Garabedian,

U.S. Geological Survey

4:30 SIMULATION OF THE CHEMICAL EVOLUTION OF A PLUME OF ACIDIC GROUND WATER

K.G. Stollenwerk, U.S. Geological Survey $\ldots \ldots \ldots$

SESSION 5

Water Quality Assessments

Page

3:10 INVITED SPEAKER

IS WATER A RELEVANT SAMPLING MEDIUM FOR TOXIC CHEMICALS?

AN ALTERNATIVE ENVIRONMENTAL SENSING STRATEGY

Edwin D. Ongley*, D.A. Birkholz, J.H. Carey, and M.R. Samoiloff, Canada

Centre for Inland Waters $\ldots \ldots \ldots \ldots$

3:30 DELINEATION OF FACTORS RELATED TO THE OCCURRENCE OF

1,2-DIBROMOETHANE IN GROUND WATER, CENTRAL FLORIDA

Anne F. Choquette*, Brian G. Katz, William S. Pendexter, and Miguel A. Orona,

U.S. Geological Survey $\ldots \ldots \ldots \ldots \ldots$

3:50 COMPARISON OF ANALYTICAL APPROACHES FOR ASSESSING

TRACE-ORGANIC COMPOUNDS IN THE YAKIMA RIVER BASIN, WASHINGTON

Joseph F. Rinella*, Stuart W. McKenzie, and Gregory J. Fuhrer,

U.S. Geological Survey -

4:10 ECOLOGICAL ASPECTS OF THE NATIONAL WATER-QUALITY

ASSESSMENT PROGRAM

Martin E. Gurtz, U.S. Geological Survey $\quad \ldots \ldots \ldots$

4:30 TISSUE-ANALYSIS COMPONENT OF THE NATIONAL WATER-QUALITY

ASSESSMENT PROGRAM

J. Kent Crawford, U.S. Geological Survey $\quad \ldots \ldots \ldots \ldots \ldots$

SESSION 6

Program and Network Design

Page

3:10 INVITED SPEAKER

EPA'S WATER QUALITY ASSESSMENT PROCESS

Geoffrey H. Grubbs, U.S. Environmental Protection Agency _ . . . . . . . . . . . . 32

3:30 INVITED SPEAKER

USDA RESEARCH PLAN FOR WATER QUALITY

Loris E. Asmussen, U.S. Department of Agriculture 
CHEMICAL CONTAMINANTS IN THE ENVIRONMENT: ROLE OF THE FISH AND WILDLIFE SERVICE'S ENVIRONMENTAL CONTAMINANTS FIELD OPERATIONS PROGRAM

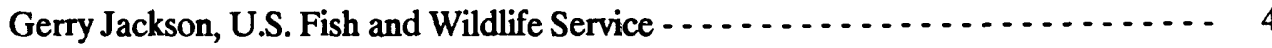

4:10 INVITED SPEAKER

EXTENT OF PESTICIDE CONTAMINATION OF GROUND WATER IN THE UNITED STATES

Patrick W. Holden, U.S. Environmental Protection Agency $\ldots \ldots \ldots \ldots$

4:30 INVITED SPEAKER

NATIONAL WATER CLEANUP UNDER THE CLEAN WATER ACT, 1976-89

Charles D. Mosher, U.S. General Accounting Office . . . . . . . . . . . . . . . . .

CONCURRENT SESSIONS

Tuesday Moming, November 14, 8:00-9:40

SESSION 7

Laboratory Methodology

Page

8:00 SUPERCRITICAL FLUID EXTRACTION (SFE) AND COUPLED SFE-GC ANALYSIS OF ENVIRONMENTAL SOLIDS AND SORBENT RESINS

Steven B. Hawthorne* and David J. Miller, University of North Dakota . . . . . . . . -

8:20 A COMPARISON OF ANALYTICAL TECHNIQUES USED FOR THE DETERMINATION OF VOLATILE AND SEMIVOLATILE ORGANIC CONTAMINANTS IN GROUND WATER

Doug Cain*, U.S. Geological Survey, James F. Pankow, Oregon Graduate Center, Daniel T. Chafin, William T. Foreman, Steven D. Zaugg, U.S. Geological Survey, Lorne F. Isabelle, Oregon Graudate Center, Michael J. Liszewski, Jacob Gibs, Brooke F. Connor, Marilyn G. Werner, Ronald Baker, and Roderick F. Ortiz, U.S. Geological Survey

8:40 EFFECTS OF ACID PRESERVATION ON THE CONCENTRATIONS OF VOLATILE ORGANIC COMPOUNDS IN NATURAL WATERS

Brooke F. Connor*, Mark W. Sandstrom, and Donna Rose, U.S. Geological Survey

9:00 EXTRACTION OF GASOLINE CONSTITUENTS FROM SOIL

Susan G. Donaldson*, Glenn C. Miller, and W.W. Miller, University of

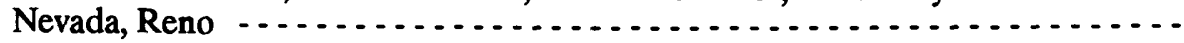

IDENTIFICATION OF THE DIFFERENCES BETWEEN ONSITE AND

LABORATORY $\mathrm{pH}$ DETERMINATIONS USING A QUALITY-ASSURANCE PROGRAM

LeRoy J. Schroder*, Randolph B. See, and Timothy C. Willoughby,

U.S. Geological Survey

\section{SESSION 8}

Nonpoint Sources

Page

8:00 EVALUATING NONPOINT-SOURCE CONTAMINANTS IN THE CONESTOGA HEADWATERS, PENNSYVANIA

Kevin M. Kostelnik, U.S. Geological Survey 
8:20 THE EFFECTS OF LAND-MANAGEMENT PRACTICES ON SURFACE- AND GROUND-WATER QUALITY IN RURAL NORTHEASTERN GUILFORD COUNTY, NORTH CAROLINA

Catherine L. Hill, U.S. Geological Survey $\ldots \ldots \ldots$

8:40 HERBICIDES IN SURFACE AND GROUND WATER, CEDAR RIVER BASIN, IOWA AND MINNESOTA

Paul J. Squillace*, Mark W. Sandstrom, and Wilfred E. Pereira,

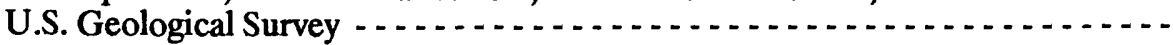

9:00 EFFECTIVENESS OF AQUIFERS IN THE DILUTION OF NONPOINT SOURCE

LOW MCL CONTAMINANTS

W. Bruce Moore* and Honesto Roaza, Northwest Florida Water Management

District

9:20 THE ROLE OF SUBMARINE GROUNDWATER DISCHARGE TO NUTRIENT

FLUX IN COASTAL AND OCEANIC ENVIRONMENTS

George M. Simmons, Jr., Virginia Polytechnic Institute and State University . . . . . -

SESSION 9

Subsurface Microbiology

Page

8:00 MEASURING HYDROGEN CONCENTRATIONS IN GROUND WATER:

A TOOL FOR EVALUATING BACTERIAL PROCESSES IN DEEP

AQUIFER SYSTEMS

Francis H. Chapelle* and Derek R. Lovley, U.S. Geological Survey

8:20 THE PRODUCTION AND CARBON ISOTOPIC COMPOSITION OF BACTERIAL $\mathrm{CO}_{2}$ IN DEEP COASTAL PLAIN SEDIMENTS OF SOUTH CAROLINA

Peter B. McMahon*, U.S. Geological Survey, and Douglas F. Williauns, University

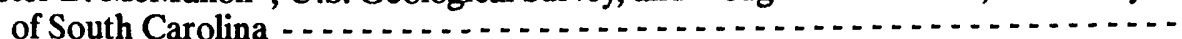

8:40 ABILITY OF MICROBIAL COMMUNITIES FROM A PRISTINE AQUIFER TO DEGRADE XENOBIOTIC COMPOUNDS

C. Marjorie Aelion*, U.S. Geological Survey, and Frederic K. Pfaender, University of North Carolina -

9:00 MICROBIALLY CATALYZED REDUCTION OF IRON AND MANGANESE

Derek R. Lovley* and Elizabeth J.P. Phillips, U.S. Geological Survey - . . . . . . . . .

9:20 OXIDATION OF AROMATIC CONTAMINANTS COUPLED TO MICROBIAL REDUCTION OF IRON

Derek R. Lovley, Debra J. Lonergan*, Elizabeth J.P. Phillips, and Isabelle M.

Cozzarelli, U.S. Geological Survey . . . . . . . . . . . . . . . . . . . . . . . .

\section{CONCURRENT SESSIONS}

Tuesday Moming, November 14, 10:00-11:40

SESSION 10

Geochemistry

10:00 GLACIAL-ICE GEOCHEMISTRY, KNIFE POINT GLACIER, WIND RIVER

RANGE, WYOMING--RECONNAISSANCE-PHASE RESULTS

David L. Naftz*, Howard E. Taylor, U.S. Geological Survey, Jaines A. Rice, South Dakota State University, and Janes R. Ranville, U.S. Geological Survey - - 66

10:20 GEOCHEMISTRY OF IRON IN A SAND DUNE AQUIFER USED FOR

MUNICIPAL AND INDUSTRIAL WATER SUPPLY NEAR COOS BAY AND

NORTH BEND, OREGON

Gilbert C. Bortleson, U.S. Geological Survey 
10:40 AQUEOUS GEOCHEMISTRY OF THE SAND-AND-GRAVEL AQUIFER AND

THE FLORIDAN AQUIFER SYSTEM, FLORIDA

Brian G. Katz*, Anne F. Choquette, and Ruth M. Roaza, U.S. Geological Survey - -

11:00 WATER-CHEMISTRY AND BIOLOGICAL RECONNAISSANCE OF CORE MATERIAL FROM HYDROGEOLOGIC UNITS IN THE COASTAL PLAIN OF NEW JERSEY

Amleto A. Pucci, Jr.*, Ted Ehlke, and James P. Owens, U.S. Geological Survey - - -

11:20 GEOCHEMICAL CONTROLS ON RADIONUCLIDE MOBILITY IN SHALLOW GROUND WATER NEAR AN EPHEMERAL STREAM IN NORTHEASTERN ARIZONA

P.C. Van Metre*, Laurie Wirt, and J.R. Gray, U.S. Geological Survey . . . . . . . .

SESSION 11

Irrigation Drainage Program

10:00 SPECIATION OF SOLUBLE AND ADSORBED SELENIUM IN SOILS, WESTERN SAN JOAQUIN VALLEY, CALIFORNIA

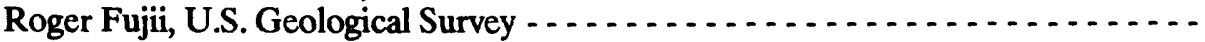

10:20 GROUND-WATER FLOW TO SUBSURFACE AGRICULTURAL DRAINS IN

THE WESTERN SAN JOAQUIN VALLEY, CALIFORNIA

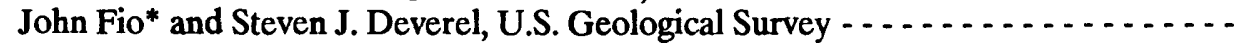

10:40 CONTROLS ON DRAINWATER COMPOSITION IN THE IMPERIAL VALLEY,

CALIFORNIA

Roy A. Schroeder*, James G. Setmire, and Jill N. Densmore,

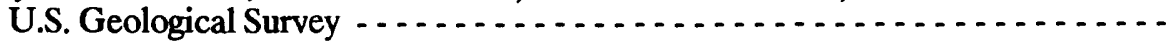

11:00 MERCURY AND SELENIUM CONCENTRATIONS IN SURFACE WATER,

BOTTOM SEDIMENT, AND BIOTA, STILLWATER WILDLIFE

MANAGEMENT AREA AND VICINITY, CHURCHILL COUNTY, NEVADA

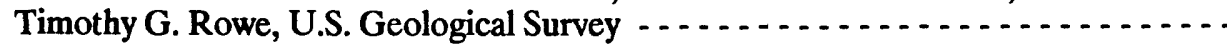

11:20 SELENIUM IN SOILS AND VEGETATION AT THE KENDRICK

RECLAMATION PROJECT AREA, WYOMING

James G. Crock*, R.C. Severson, and J.A. Erdman, U.S. Geological Survey . . . . .

SESSION 12

Water Quality Assessment

Page

10:00 DEVELOPMENT OF SURFACE WATER QUALITY STANDARDS FOR TOXIC SUBSTANCES "THE WISCONSIN EXPERIENCE"

John R. Sullivan, Wisconsin Department of Natural Resources . . . . . . . . . . . .

10:20 DATA MANAGEMENT, CLEANUP, AND ANALYSIS FOR FLORIDA'S AMBIENT BACKGROUND GROUND WATER MONITORING NETWORK

Tim Glover, Florida Department of Environmental Regulation . . . . . . . . . . . . .

10:40 APPLICATION OF GEOGRAPHIC INFORMATION SYSTEMS TO STATEWIDE WATER-QUALITY ASSESSMENT

R.A. Smith*, R.B. Alexander, K.W. Robinson, C.V. Price, D.A. White, K.F. Lins, and S.K Jenson, U.S. Geological Survey $\ldots \ldots \ldots \ldots \ldots$

11:00 RESULT OF A WATER QUALITY MONITORING AND MODELING PROGRAM FOR THE PATUXENT RIVER BASIN, MARYLAND

Robert M. Summers, Maryland Department of the Environment 
11:20 APPLICATION OF A WATER-QUALITY INDEX

Eliane D. Abdala, Ministerio Da Ciencia E Tecnologia De Minas Gerais,

Brazil, and Herman R. Feltz*, U.S. Geological Survey - . . . . . . . . . . . . . .

\section{CONCURRENT SESSIONS}

Wednesday Moming, November 15, 8:00-9:40

SESSION 13

Quality Assurance

Page

8:00 SUGGESTIONS FOR A QUALITY ASSURANCE PROGRAM FOR

EVALUATING LABORATORIES

David E. Erdmann, U.S. Geological Survey $\quad \ldots \ldots \ldots \ldots$

8:20 ASSURING DATA QUALITY AT THE U.S. GEOLOGICAL SURVEY NATIONAL

WATER QUALITY LABORATORY

Jeffrey W. Pritt, U.S. Geological Survey

RETRIEVAL AND ANALYSIS OF THE RESULTS FROM THE BLIND SAMPLE

QUALITY-ASSURANCE PROGRAM AT THE NATIONAL WATER QUALITY

LABORATORY OF THE U.S. GEOLOGICAL SURVEY

Keith J. Lucey, U.S. Geological Survey $\ldots \ldots \ldots \ldots$

9:00 STATISTICAL APPLICATIONS USED IN THE U.S. GEOLOGICAL SURVEY'S

EVALUATION PROGRAM FOR STANDARD REFERENCE SAMPLES

H. Keith Long, U.S. Geological Survey $\ldots \ldots \ldots \ldots \ldots$

9:20 QUALITY-ASSURANCE PROGRAM FOR A PRECIPITATION-MONITORING

NETWORK

R.B. See, B.A. Malo*, L.J. Schroder, and T.C. Willoughby, U.S. Geological Survey -

SESSION 14

Field Methods

\section{Field Methods}

8:00 FIELD METHOD FOR SOLID-PHASE EXTRACTION OF HERBICIDES IN SURFACE AND GROUND WATER

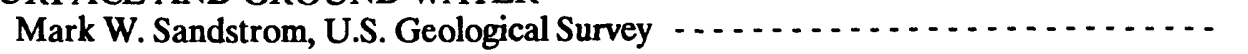

8:20 IMPROVED SAMPLING METHODS FOR ORGANIC CONSTITUENTS

Larry R. Shelton, U.S. Geological Survey $\ldots \ldots \ldots \ldots$

Page

82

8:40 DETECTION OF COLLOIDS BY ULTRAFILTRATION DOWNSTREAM FROM

ACID MINE DRAINAGE, UPPER ARKANSAS RIVER, COLORADO

Briant A. Kimball*, Gregory A. Wetherbee, E.C. Callender, and Ellen Axtman

U.S. Geological Survey $\ldots \ldots \ldots \ldots$

9:00 ACCURACY OF USGS MINIMONITOR MEASUREMENTS IN LOW SOLUTE CONTENT STREAMS

D.V. Peck*, M.A. Stapanian, R.C. Metcalf, Lockheed Engineering \& Sciences Co., Inc., and D.T. Heggem, U.S. Environmental Protection Agency … . . . . . . . .

9:20 EVALUATION OF A MODIFIED COMMERCIAL AUTOMATIC SAMPLER FOR THE COLLECTION OF WATER SAMPLES CONTAINING TRACE ORGANICS

D.Y. Tai*, Marshall E. Jennings, Kevin D. White, and L.A. Garcia, U.S. Geological

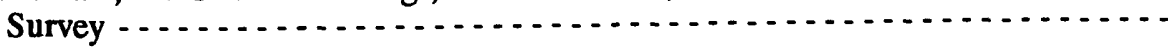




\section{SESSION 15}

Subsurface Microbiology

Page

8:00 TRANSPORT OF BACTERIA THROUGH CONTAMINATED AQUIFER SEDIMENTS IN SMALL-SCALE TRACER EXPERIMENTS: THE ROLE OF SORPTIVE FILTRATION

Ronald W. Harvey* and Stephen P. Garabedian, U.S. Geological Survey ... . . . . 35

8:20 USE OF DNA (DEOXYRIBONUCLEIC ACID) AND TANC (TOTAL ADENYLATE NUCLEOTIDE CONTENT) MEASUREMENTS FOR DELINEATING MICROBIAL ACTIVITY AND ESTIMATION OF BIOMASS IN AN ORGANICALLY CONTAMINATED AQUIFER

David W. Metge*, Ronald W. Harvey, Myron H. Brooks, and Richard L. Smith,

U.S. Geological Survey $\ldots \ldots \ldots \ldots$

8:40 SORPTION AND DESORPTION OF HYDROPHOBIC ORGANIC CONTAMINANTS IN SATURATED GROUNDWATER SYSTEMS

C.T. Miller* and J.A. Pedit, University of North Carolina

DEPRESSED REDOX POTENTIAL TO ENHANCE MICROBIAL DECHLORINATION OF PCBs

Stephen F. Pederson* and Ronald D. Neufeld, University of Pittsburgh

THE ANAEROBIC BIOREMEDIATION OF TCE CONTAMINATED AQUIFERS; A FEASIBILITY STUDY

Peter R. Jaffe'*, Stewart W. Taylor, and Naresh Singhal, Princeton University - . - -

\section{CONCURRENT SESSIONS}

Wednesday Moming, November 15, 10:00-11:40

\section{SESSION 16}

Mississippi River Studies

Page

10:00 SAMPLING STRATEGIES AND PROCEDURES FOR TRACKING TOXIC CHEMICALS THROUGH LARGE RIVER SYSTEMS SUCH AS THE MISSISSIPPI RIVER

Robert H. Meade, U.S. Geological Survey

10:20 OCCURRENCE AND DISTRIBUTION OF TRACE METALS IN THE MISSISSIPPI RIVER

Howard E. Taylor*, John R. Garbarino, and Terry I. Brinton, U.S. Geological

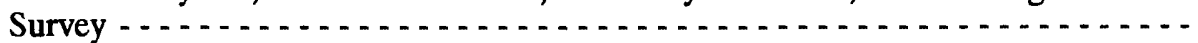

10:40 OCCURRENCE, DISTRIBUTION, TRANSPORT AND FATE OF SYNTHETIC ORGANIC CONTAMINANTS IN THE LOWER MISSISSIPPI RIVER AND ITS MAJOR TRIBUTARIES

W.E. Pereira*, C.E. Rostad, and T.J. Leiker, U.S. Geological Survey . . . . . . . 72

11:00 DETERMINATION OF HALOGENATED ORGANIC COMPOUNDS IN MISSISSIPPI RIVER SUSPENDED SEDIMENT BY NEGATIVE ION CHEMICAL IONIZATION MASS SPECTROMETRY

C.E. Rostad*, W.E. Pereira and T.J. Leiker, U.S. Geological Survey . . . . . . . .

11:20 POLYETHYLENE-GLYCOL RESIDUES FROM NONIONIC SURFACTANTS IN THE LOWER MISSISSIPPI RIVER

J.A. Leenheer*, R.L. Wershaw, P.A. Brown, and T.I. Noyes,

U.S. Geological Survey 
10:00 OCCURRENCE AND MOVEMENT OF RADIONUCLIDES IN THE PUERCO RIVER BASIN, ARIZONA AND NEW MEXICO Laurie Wirt*, J.R. Gray, and P.C. Van Metre, U.S. Geological Survey - . . . . . . . 109

10:20 HYDROGEOLOGIC CONTROLS ON THE DISTRIBUTION OF RADON-222 IN GROUND WATER OF WEST-CENTRAL NEVADA Jennifer L. Hughes*, Michael S. Lico, and Alan H. Welch, U.S. Geological Survey - 40

10:40 STABLE CARBON-ISOTOPE RATIOS AS TRACERS OF SOURCES OF ALKALINITY IN SMALL WATERSHEDS Carol Kendall, U.S. Geological Survey $\ldots \ldots \ldots \ldots$

11:00 USE OF DEUTERIUM AND OXYGEN-18 TO TRACE THE INDUCED

INFILTRATION OF DELAWARE RIVER WATER INTO THE POTOMAC-RARITAN-MAGOTHY AQUIFER SYSTEM, CAMDEN AREA, NEW JERSEY

Steven D. McAauley* and Carol Kendall, U.S. Geological Survey $\ldots . . . . . . . .556$

11:20 APPLIED RESEARCH USING CHLORINE-36 AS A HYDROGEOLOGIC TOOL G. Vourvopoulos*, Western Kentucky University, J.V. Brahana and T.F. Kraemer, U.S. Geological Survey, W. Wolfli, M. Suter, and A. Synal, Federal Institute of Technology, Switzerland

\section{SESSION 18}

Program and Network Design

Page

10:00 INVITED SPEAKER

EPA'S NONPOINT SOURCE PROGRAM

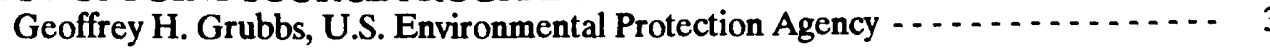

10:20 INVITED SPEAKER

THE AMBIENT GROUND-WATER OUALITY MONITORING PROGRAM OF FLORIDA

Rick Copeland, Florida Department of Environmental Regulation - . . . . . . . .

10:40 INVITED SPEAKER

APPLICATION OF THE BATTERY OF TESTS APPROACH AND RANKING

SCHEME TO ENVIRONMENTAL SAMPLES

B. J. Dutka. Canada Centre of Inland Waters $\ldots \ldots \ldots \ldots 19$

11:00 INVITED SPEAKER

GROUNDWATER PROTECTION PROGRAMS IN ILLINOIS: APPLICATION

OF GEOLOGIC MAPPING AND BASIC HYDROGEOLOGIC PRINCIPLES

Dennis P. McKenna*, Richard C. Berg, and John P. Kempton. Illinois State

Geological Survey

11:20 INVITED SPEAKER

WESTERN INVESTIGATIONS OF IRRIGATION-INDUCED WATER-QUALITY

PROBLEMS

Jonathan P. Deason, U.S. Department of the Interior $\ldots \ldots \ldots \ldots$

11:40 INVITED SPEAKER

NATIONAL PARK SERVICE WATER-QUALITY PROGRAM

Nancy E. Driver, National Park Service 


\section{CONCURRENT SESSIONS}

Wednesday Aftemoon, November 15, 1:00-2:40

SESSION 19

Mississippi River Studies--Mercury Contamination

Page

A RECONNAISSANCE STUDY OF THE DISTRIBUTION OF HALOGENATED ORGANIC COMPOUNDS IN CATFISH FROM THE LOWER MISSISSIPPI RIVER AND ITS TRIBUTARIES

Thomas J. Leiker*, Wilfred E. Pereira, Colleen E. Rostad, and Charles Barnes,

U.S. Geological Survey $\ldots \ldots \ldots \ldots$

1:20 URANIUM-SERIES RADIONUCLIDES IN THE MISSISSIPPI RIVER

Brent A. McKee, Louisiana Universities Marine Consortium - . . . . . . . . . . . . 57

1:40 RADIUM IN THE LOWER MISSISSIPPI RIVER

T.F. Kraemer, U.S. Geological Survey $\ldots \ldots \ldots \ldots$

2:00 CONSIDERATIONS IN INTERPRETING MERCURY CONCENTRATIONS IN

WATER SAMPLES COLLECTED BY THE U.S. GEOLOGICAL SURVEY

Wayne E. Webb, U.S. Geological Survey $\ldots \ldots \ldots$

2:20 EFFECT OF STORING DILUTE MERCURY SOLUTIONS IN POLYETHYLENE BOTTLES

Marvin J. Fishnıan*, David E. Erdmann, and Jerry V. Farrar, U.S. Geological

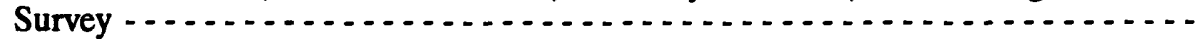

SESSION 20

Water Quality Assessments

Page

1:00 ENHANCEMENT OF A HYDROLOGIC BENCH-MARK NETWORK SITE John T. Turk, U.S. Geological Survey $\ldots \ldots \ldots \ldots 1$

1:20 USE OF MULTIVARIATE TECHNIQUES FOR BACKGROUND AND ANTHROPOGENIC-SOURCE ANALYSIS OF TRACE ELEMENTS IN STREAMBED MATERIALS IN THE UPPER ILLINOIS RIVER BASIN IN ILLINOIS, INDIANA, AND WISCONSIN

Steven M. Smith, Richard F. Sanzolone, and John A. Colman*,

U.S. Geological Survey

1:40 OCCURRENCE AND DISTRIBUTION OF NUTRIENTS AND DISSOLVED OXYGEN IN THE UPPER ILLINOIS RIVER BASIN IN ILLINOIS, INDIANA, AND WISCONSIN: RESULTS OF A 1988 LOW-FLOW SYNOPTIC SURVEY

Paul J. Terrio, U.S. Geological Survey $\ldots \ldots \ldots \ldots \ldots$

2:00 EFFECT OF FLOW CONDITIONS ON STREAM REAERATION COEFFICIENTS James L. Smoot, U.S. Geological Survey

2:20 ANALYSIS OF VARIANCE IN THE SAMPLING OF STREAMBED MATERIALS FOR ANTHROPOGENIC ORGANIC COMPOUNDS

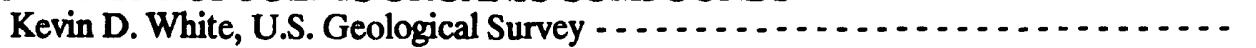
107

\section{SESSION 21}

Aquatic Biology

Page

1:00

INVERTEBRATE DRIFT AS A BIOLOGICAL INDICATOR OF WATER

QUALITY

Keith V. Slack*, Larry J. Tilley, and Susan S. Kennelly, U.S. Geological Survey - - - -

91 
1:20 COMPARATIVE BIOCONCENTRATION OF SELENATE AND SELENITE

BY BLUEGILL (LEPOMIS MACROCHIRUS) AND FATHEAD MINNOWS

(PIMEPHALES PROMELAS)

Richard S. Ogle* and Allen W. Knight, University of California, Davis . . . . . . . .

1:40 THE EFFECTS OF FRESHWATER INFLOW ON THE PHYTOPLANKTON

CARBON-14 PRODUCTIVITY AND CHLOROPHYLL-A IN THE

CHARLOTTE HARBOR ESTUARINE SYSTEM, SOUTHWESTERN FLORIDA

Benjamin F. McPherson*, U.S. Geological Survey, and Ralph T. Montgomery,

Environmental Quality Laboratory, Inc.

2:00 PRIMARY PRODUCTION OF BIG LAKE, SOUTH-CENTRAL ALASKA

Paul F. Woods, U.S. Geological Survey

2:20 THE BACTERIOLOGICAL QUALITY OF STREAMS IN TROPICAL ISLANDS

Roger S. Fujioka*, University of Hawaii, and Johnson Yee, U.S. Geological Survey -

\section{CONCURRENT SESSIONS}

Wednesday November 15, 3:10-4:50

SESSION 22

Agricultural Chemicals

3:10 A RECONNAISSANCE FOR TRIAZINE HERBICIDES IN SURFACE WATERS OF THE UPPER MIDWESTERN UNITED STATES

Donald A. Goolsby*, E. Michael Thurman, Dana W. Kolpin, and Mark G. Detroy,

U.S. Geological Survey $\ldots \ldots \ldots \ldots \ldots$

3:30 CONTAMINATION OF GROUND AND SURFACE WATER BY

AGRICULTURAL CHEMICALS, BIG SPRING BASIN, CLAYTON COUNTY, IOWA

Stephen J. Kalkhoff, U.S. Geological Survey

3:50 IMPACT OF AN ARTIFICIAL RECHARGE STRUCTURE ON PESTICIDE CONCENTRATIONS IN THE ADJACENT GROUND WATER

Mary E. Exner, University of Nebraska $\ldots \ldots \ldots \ldots$

4:10 INDICATORS OF PESTICIDES IN SHALLOW AQUIFERS IN IOWA

Dana W. Kolpin* and Michael R. Burkart, U.S. Geological Survey - . . . . . . . . . . . 47

4:30 VARIATION IN CONCENTRATIONS OF ATRAZINE AND NITRATE IN GROUND WATER BENEATH AN IRRIGATED CORN FIELD NEAR SHELTON, NEBRASKA

A. Douglas Druliner*, Abraham H. Chen, and Dwight Q. Tanner,

U.S. Geological Survey

\section{SESSION 23}

Ground Water Toxics

Page

3:10 GROUND-WATER CHEMISTRY AT THE BUILDING 24 RESEARCH SITE

PICATINNY ARSENAL, NORTH-CENTRAL NEW JERSEY

Thomas E. Imbrigiotta* and Patrick J. Witkowski, U.S. Geological Survey - . . . . . -

VOLATILE ORGANIC ACIDS IN ORGANIC-RICH AQUIFERS

Mary Jo Baedecker, Isabelle Cozzarelli*, and Don Goerlitz,

U.S. Geological Survey

3:50 ADSORPTION OF TRICHLOROETHYLENE TO MICROBIAL BIOMASS AND

PEAT AT PICATINNY ARSENAL, NEW JERSEY

Theodore A. Ehlke, U.S. Geological Survey 
4:10 NONPOINT SOURCE CONTAMINATION OF GROUND WATER IN CENTRAL

FLORIDA FROM URBAN RUNOFF, CITRUS CULTIVATION, AND

PHOSPHATE MINING

Edward R. German, U.S. Geological Survey - . . . . . . . . . . . . . . . . .

4:30 HYDROLOGIC AND GEOLOGIC FACTORS AFFECTING THE SHAPE OF A SEWAGE PLUME ON CAPE COD, MASSACHUSETTS

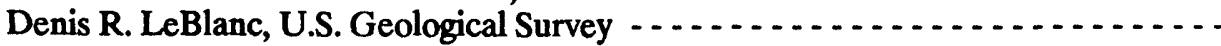

SESSION 24

Atmospheric Deposition

Page

3:10 GEOCHEMICAL PROCESSES AFFECTING STREAMWATER SOLUTE COMPOSITION AND TRANSPORT IN A FORESTED PIEDMONT WATERSHED

Norman E. Peters, U.S. Geological Survey

3:30 FACTORS CONTROLLING AQUEOUS SULFATE CONCENTRATIONS AT

PANOLA MOUNTAIN, GEORGIA

James B. Shanley*, Norman E. Peters, and Richard P. Hooper,

U.S. Geological Survey

3:50 A COMPARISON OF RESULTS FROM FIXED-INTERVAL AND STORM-BASED SAMPLING AT A CALIBRATED WATERSHED IN THE GEORGIA

PIEDMONT

Richard P. Hooper*, Norman E. Peters, and James B. Shanley,

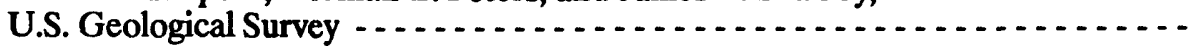

4:10 PRECIPITATION AND STREAM-WATER CHEMISTRY IN NORTH-CENTRAL MARYLAND

Karen C. Rice* and Owen P. Bricker, U.S. Geological Survey . . . . . . . . . . . . 76

4:30 CHEMISTRY OF SNOWPACK AND GROUND WATER IN THE VICINITY OF TWO NORTHWESTERN WISCONSIN SEEPAGE LAKES

Dennis A. Wentz, U.S. Geological Survey $\ldots \ldots \ldots \ldots \ldots$. . . . . . . . . . . . . . . . 107

CONCURRENT SESSIONS

Thursday Moming, November 16, 8:00-9:40

SESSION 25

Laboratory Methodology

8:00 EFFECTS OF EXTRACTION PROCEDURES ON ANALYSIS OF WATER FROM CONFINING UNITS IN THE NEW JERSEY COASTAL PLAIN

Mark A. Hardy* and Amleto A. Pucci, Jr., U.S. Geological Survey - . . . . . . . . . . .

Page

8:20 LOW-LEVEL NUTRIENT ANALYSIS OF NATURAL-WATER SAMPLES USING

A RAPID-FLOW ANALYZER

Donna L. Milne*, Merle Shockey, Tom Bushly, and Carl Harris,

U.S. Geological Survey

RAPID DETECTION OF HUMAN ENTEROVIRUSES RECOVERED FROM WATER BY THE NITROCELLULOSE-ENZYME IMMUNOASSAY (NC-EIA) AND ITS AMPLIFICATION BY STREPTAVIDIN-BIOTIN (SAB)

Philip C. Loh*, Roger S. Fujioka, and L. Stephen Lau, University of Hawaii . . . . . .

9:00 ANALYSIS OF TOTAL NITROGEN IN NATURAL WATER SAMPLES USING PYROCHEMILUMINESCENCE--A SMALL VOLUME, ACID-FREE TECHNIQUE

Linda K. Pratt* and Merle W. Shockey, U.S. Geological Survey 
9:20 IMPROVING SENSITIVITY AND CONTROLLING ENHANCEMENT EFFECTS IN DIRECT CURRENT PLASMA OPTICAL EMISSION SPECTROSCOPY

Edward J. Zayhowski* and Mark R. Hill, U.S. Geological Survey 110

\title{
SESSION 26
}

\author{
Surface Water Toxics
}

8:00 RESULTS OF BIOLOGICAL UPTAKE TESTS, TOXICITY TESTS AND CHEMICAL ANALYSES OF WATER AND BOTTOM MATERIAL FROM BAYOU D' INDE AND THE LOWER CALCASIEU RIVER, LOUISIANA Charles R. Demas* and Dennis K. Demcheck, U.S. Geological Survey, Philip Crocker and George Morrison, U.S. Environmental Protection Agency - 16

8:20 THE RELATION OF TOXICITY-TEST RESULTS TO PHASE ASSOCIATION AND CONCENTRATION OF CHROMIUM, MANGANESE, IRON AND AMMONIUM IN THE WATER COLUMN AND SEDIMENTS OF AN INDUSTRIALLY AFFECTED AREA OF THE CALCASIEU RIVER, LOUISIANA

N.S. Simon, U.S. Geological Survey $\ldots \ldots \ldots$

Page

8:40 TOXICITY OF SEDIMENTS, EFFLUENTS AND RECEIVING WATERS OF THE LOWER CALCASIEU RIVER, LOUISIANA George Morrison*, Elise Torello, and Michele Redmond, U.S. Environmental

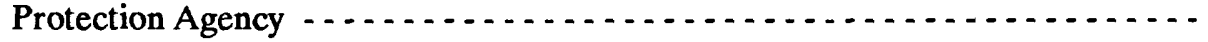

9:00 GEOGRAPHICAL DISTRIBUTIONS OF TRACE ELEMENTS IN BOTTOM MATERIAL AND SUSPENDED SEDIMENT IN THE YAKIMA RIVER BASIN, IN CENTRAL WASHINGTON

Gregory J. Fuhrer*, Stuart W. McKenzie, Joseph F. Rinella, and Richard F. Sanzolone, U.S. Geological Survey - . . . . . . . . . . . . . . . . . . .

9:20 SOLID-AND SOLUTE-PHASE TRANSPORT OF ARSENIC IN WHITEWOOD CREEK, SOUTH DAKOTA

Kimball E. Goddard* and William R. Roddy, U.S. Geological Survey - . . . . . . . . -

SESSION 27

Wastewater Treatment

8:00 RELATION OF STORM-WATER PERCOLATE TO GROUND-WATER QUALITY AT THREE STORM-WATER-MANAGEMENT FACILITIES IN MARYLAND

Franceska D. Wilde, U.S. Geological Survey $\ldots \ldots \ldots \ldots$

8:20 ATTENUATION OF NITROGEN AND FECAL COLIFORMS FROM SEPTIC-TANK EFFLUENT THROUGH A THICK UNSATURATED ZONE, UPPER MOJAVE RIVER BASIN, CALIFORNIA

Amjad M.J. Umari*, Peter Martin and Roy A. Schroeder, U.S. Geological Survey - -

8:40 NITRATE IN GROUND WATER AT A FARM IRRIGATED WITH TREATED SEWAGE AND INORGANIC FERTILIZERS, TALLAHASSEE, FLORIDA

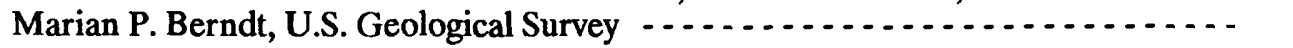

9:00 THE TRINITY RIVER, TEXAS: A CASE STUDY OF THE LIMITS OF WASTE-LOAD ALLOCATION

James Patek*, Jones and Neuse, Inc., George Ward, University of Texas at Austin,

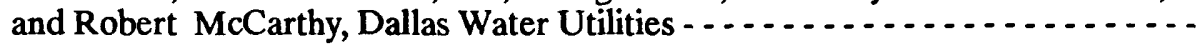


9:20 POTENTIAL USE OF CONSTRUCTED WETLANDS TO TREAT LANDFILL

LEACHATE

Jan M. Surface*, U.S. Geological Survey, Tammo S. Steenhuis, William E. Sanford, John H. Peverly and Robert J. Kopka, Cornell University, Mitchell J. Lavine,

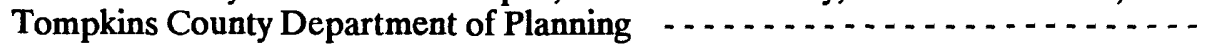

\section{CONCURRENT SESSIONS}

Thursday Moming, November 16, 10:00-11:40

\section{SESSION 28}

Field Methods

10:00 UTILITY AND LIMITATIONS OF IMMUNOASSAY TESTS AS A FIELD

SCREENING METHOD FOR TRIAZINE HERBICIDES

Peter A. Schulze and Paul D. Capel*, U.S. Geological Survey . . . . . . . . . . . . . 86

10:20 A RAPID SCREENING METHOD FOR ESTIMATING ATRAZINE AND ITS

METABOLITES IN NATURAL WATER SAMPLES

M.G. Ondrus, University of Wisconsin-Stout, and T.R. Steinheimer*,

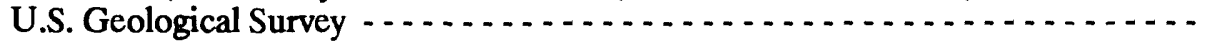

10:40 EXPERIMENTAL SURFACE-WATER SAMPLING DEVICE FOR

AGRICULTURAL FIELD-RUNOFF INVESTIGATIONS

Charles A. Perry* and E.M. Thurman, U.S. Geological Survey - . . . . . . . . . . 72

11:00 FIELD MEASUREMENTS OF DISSOLVED NITROGEN AND OXYGEN IN

GROUND WATERS OF THE BLACK HILLS AREA, SOUTH DAKOTA

Mark T. Anderson*, U.S. Geological Survey, and Janelle M. Williams,

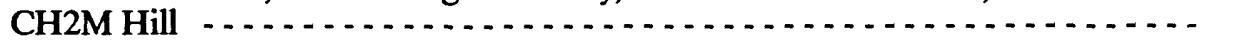

11:20 CONCENTRATING SUSPENDED SEDIMENT FOR ORGANIC ANALYSIS

Michael Meyer*, E.M. Thurman, and Robert Bannister, U.S. Geological Survey - . -

Page

SESSION 29

Sediment Chemistry

10:00 INTERMETALLIC CONTROLS ON MERCURY PARTITIONING IN BED SEDIMENTS OF NORTHERN WISCONSIN SEEPAGE LAKES

John F. Elder, U.S. Geological Survey

MODELING AQUATIC SEDIMENT-ASSOCIATED TRACE ELEMENT

CONCENTRATIONS USING SELECTED GEOCHEMICAL FACTORS

Arthur J. Horowitz*, Kent A. Elrick, and Richard P. Hooper,

U.S. Geological Survey

10:40 PARTITIONING OF ELEMENTS BETWEEN TWO SIZE FRACTIONS IN SEDIMENT SAMPLES FROM THE WESTERN UNITED STATES

Thelına F. Harms*, R.C. Severson, and K.C. Stewart, U.S. Geological Survey - - - -

11:00 ACCUMULATION OF ORGANOCHLORINE PESTICIDE AND PCB RESIDUES IN THE SEDIMENTS OF ICEDALE LAKE, CHESTER COUNTY, PENNSYLVANIA

Craig R. Moore* and James R. Kolva, U.S. Geological Survey - . . . . . . . . . .

11:20 GEOCHEMICAL CONSEQUENCES OF RAPID SEDIMENTATION IN

RESER VOIR LAKES RECEIVING MINING WASTES

Edward Callender* and Walter H. Ficklin, U.S. Geological Survey - 
SESSION 30

Aquatic Biology

Page

10:00 INVITED SPEAKER

ALTERNATIVES TO THE MEASUREMENT OF TISSUE CONCENTRATIONS FOR DOCUMENTING EXPOSURE TO AND EFFECTS OF CONTAMINANTS IN FISH

Christopher J. Schmitt* and Bryan L. Steadman, U.S. Fish and

Wildlife Service

PHYTOPLANKTON DYNAMICS IN ROCKY MOUNTAIN LAKES AND

POTENTIAL RESPONSE TO CHANGES IN LAKEWATER CHEMISTRY

Diane M. McKnight*, Richard Smith, and J. Platt Bradbury, U.S. Geological Survey, Jill Baron and Sarah Spaulding, National Park Service . . . . . . . . . . . . . . . . .

10:40 THE APPLICATION OF FUGACITY MODELS TO ASSESS CHEMICAL PARTITIONING IN WETLANDS Joseph J. Delfino* and Kathleen J. O'Neil, University of Florida

11:00 EFFECT OF INJURY INDUCED BY AQUATIC STRESS ON INDICATOR AND ENTERIC PATHOGENIC BACTERIA

Gordon A. McFeters*, and Ajaib Singh, Montana State University - . . . . . . . . . . .

11:20 RELATIONS BETWEEN FISH POPULATIONS AND WATER QUALITY IN THE UPPER ILLINOIS RIVER BASIN IN ILLINOIS, INDIANA, AND WISCONSIN: ANALYSIS OF EXISTING INFORMATION

Peter M. Ruhl* and Robert G. Striegl, U.S. Geological Survey - . . . . . . . . . . . . 


\section{POSTER PRESENTATIONS}

Page

SURFACE-WATER QUALITY OF THE UPPER ILLINOIS RIVER BASIN IN ILLINOIS, INDIANA, AND WISCONSIN: ANALYSIS OF EXISTING INFORMATION

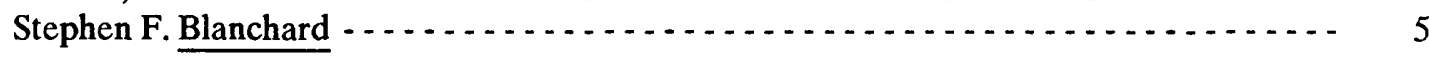

COMBINATION OF SURFACE GEOPHYSICS AND BOREHOLE MEASUREMENTS TO DEFINE GROUND WATER POLLUTION PLUMES

Istvan Bogardi, William E. Kelly, Wayne Woldt, and Andras Bardossy $\ldots \ldots \ldots \ldots$

COMPARISON OF SOLUTE COMPOSITION OF PRECIPITATION AND DECIDUOUS AND CONIFEROUS THROUGHFALL IN A PIEDMONT WATERSHED

Rosanna Cappellato -

STATISTICAL COMPARISON OF TEMPORAL AND SPATIAL VARIABILITY IN WATER QUALITY AT WELLS IN FIVE LAND-USE AREAS OF NASSAU AND SUFFOLK COUNTIES, LONG ISLAND, NEW YORK

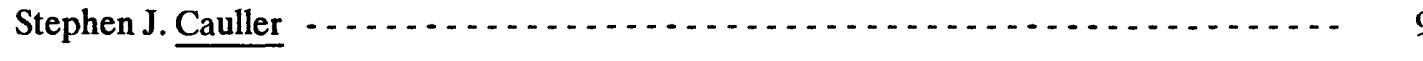

GEOCHEMICAL EVOLUTION OF GROUND WATER AT A SURFACE COAL MINE RECLAIMED WITH URBAN SEWAGE SLUDGE IN WESTERN PENNSYLVANIA

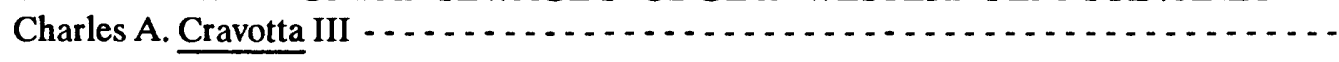

EFFECTS OF AGRICULTURAL PRACTICES ON WATER CHEMISTRY IN AN UNCONFINED COASTAL PLAIN AQUIFER, SUSSEX COUNTY, DELAWARE

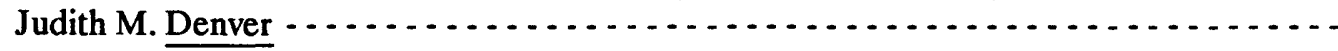

EFFECT OF OIL PRODUCTION ACTIVITIES ON SURFACE WATER QUALITY IN THE KENTUCKY RIVER BASIN, KENTUCKY

Ronald D. Evaldi, James L. Smoot, and James A. Kipp $\ldots \ldots \ldots \ldots$

APPLICATIONS OF INDUCTIVELY COUPLED PLASMA MASS SPECTROMETRY TO TRACE ELEMENT ANALYSIS OF NATURAL WATERS

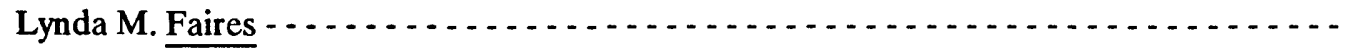

ADVANCES IN INSTRUMENTATION FOR AUTOMATICALLY MONITORING WATER QUALITY

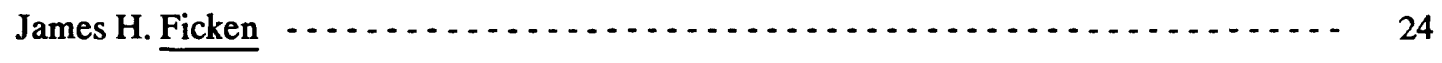

EFFECT OF SAMPLE HANDLING ON OBSERVED MERCURY CONCENTRATIONS IN USGS NATIONAL NETWORK SURFACE-WATER SAMPLES, 1973-88

Kathleen K. Fitzgerald -

SUPERCRITICAL FLUID EXTRACTION OF TRACE ORGANIC AQUATIC POLLUTANTS PRECONCENTRATED ON SOLID SORBENTS

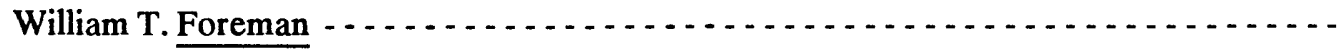


RESPONSE OF AQUATIC COMMUNITIES IN THE BOISE RIVER, IDAHO TO TRACE ELEMENTS IN MUNICIPAL WASTEWATER EFFLUENTS

Steven A. Frenzel

QUALITY OF WATER AND BOTTOM SEDIMENTS ASSOCIATED WITH IRRIGATION DRAINAGE FROM THE ANGOSTURA RECLAMATION UNIT, SOUTHWESTERN SOUTH DAKOTA

Earl A. Greene

WATER-QUALITY TRENDS OF THE ALBEMARLE-PAMLICO ESTUARINE SYSTEM, NORTH CAROLINA

Dogulas A. Harned and Marjorie S. Davenport

VARIABILITY IN THE CONCENTRATION OF VOLATILE ORGANIC COMPOUNDS DURING WELL PURGING

Beverly H. Herzog, Jacob Gibs, and Thomas E. Imbrigiotta $\ldots \ldots \ldots \ldots$

SEDIMENT-WATER INTERACTION DURING ARTIFICIAL RECHARGE THROUGH AN ORGANIC MAT

G.F. $\underline{\text { Huff }}$

A LONG-TERM PRECIPITATION MONITORING PROGRAM FOR THE UNITED STATES

F. Paul Kapinos

WATER QUALITY INVESTIGATIONS IN THE U.S. VIRGIN ISLANDS

J. Hari Krishna and Robert H. Ruskin $\ldots \ldots \ldots \ldots$

MODIFICATION OF THE QUAL2E WATER-QUALITY MODEL FOR APPLICATION TO SMALL FOOTHILL STREAMS NEAR PIKES PEAK, COLORADO

Gerhard Kuhn

DETERMINATION OF THE EXTENT OF GASOLINE CONTAMINATION OF A SHALLOW SAND AQUIFER USING SOIL GAS ANALYSES FOR VOLATILE ORGANIC COMPOUNDS IN JACKSON, TENNESSEE

Roger W. Lee

THE ANALYSIS OF ENVIRONMENTAL FACTORS CONTROLLING THE SPECIES COMPOSITION OF BENTHIC COMMUNITIES

Harry V. Leland and Steven V. Fend

GEOCHEMISTRY OF GROUND WATER AT AND NEAR FERNLEY WILDLIFE MANAGEMENT AREA, LYON COUNTY, NEVADA

Michael S. Lico $\cdots \ldots \ldots$

RESULTS FOR MERCURY IN THE BLIND SAMPLE QUALITY-ASSURANCE PROGRAM OF THE U.S. GEOLOGICAL SURVEY

Keith J. Lucey and David E. Erdmann 
DISSOLVED OXYGEN TRENDS IN THE TRINITY RIVER, TEXAS

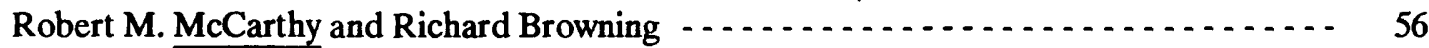

DISCHARGE-WEIGHTED PUMPING METHOD FOR COLLECTING THE FINE FRACTION OF SUSPENDED SEDIMENT

Jolin A. Moody

THE CAPACITY OF A BOTTOMLAND-HARDWOOD WETLAND TO MODIFY THE CHEMICAL AND SEDIMENT COMPOSITION OF AN ADJACENT RIVERINE SYSTEM

E.E. Morris, Barbara A. Kleiss, and Dr. Joseph F. Nix $\ldots \ldots$

OCCURRENCE AND VARIABILITY OF ESCHERICHLA COLI AND FECAL-COLIFORM DENSITIES IN THE OLENTANGY AND SCIOTO RIVERS IN THE COLUMBUS, OHIO, AREA

Donna N. Myers

MONITORING SALTWATER INTRUSION IN SOUTH CAROLINA RIVERS

Glenn G. Patterson, Rodney N. Cherry, C.L. Sanders, Jr., Larry R. Bohman, and

C.S. Bennett III

WATER QUALITY INDEX SYSTEM OF THE BRAZOS RIVER AUTHORITY

Philip W. Price

QUALITY ASSURANCE OF SAMPLE CONTAINERS AND PRESERVATIVES AT THE

U.S. GEOLOGICAL SURVEY NATIONAL WATER QUALITY LABORATORY

Jeffrey W. Pritt

ESTIMATING HISTORICAL RIVER POLLUTION TRENDS USING MASS BALANCE PRINCIPLES: SELECTED METALS IN THE HUDSON-RARITAN BASIN, 1880 TO 1980

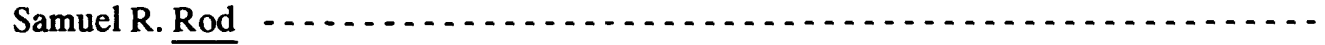

IDENTIFICATION OF ORGANIC CONTAMINANTS BY GAS

CHROMATOGRAPHY/HIGH-RESOLUTION MASS SPECTROMETRY

Peter F. Rogerson

TRANSPORT OF CHLORIDE AND ATRAZINE THROUGH THE UNSATURATED ZONE BENEATH TWO IRRIGATED FIELDS IN SOUTH-CENTRAL KANSAS

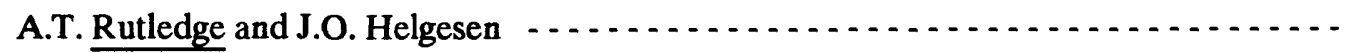

TREND ANALYSIS OF TEXAS WATER-QUALITY DATA

Terry L. Schertz and Timothy L. Miller $\ldots \ldots \ldots \ldots$

A CONSITUENT IDENTIFIER SYSTEM FOR THE NATIONAL WATER INFORMATION SYSTEM (NWIS-II)

James C. Schornick 
ANALYSIS OF ORGANIC CONTAMINANTS AT THE NATIONAL WATER QUALITY LABORATORY OF THE U.S. GEOLOGICAL SURVEY II. METHODOLOGICAL IMPROVEMENTS IN SEDIMENT ANALYSES

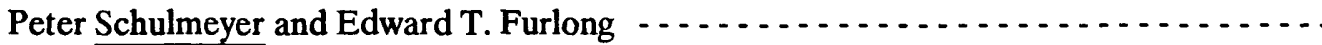

STRATEGY FOR GROUND-WATER QUALITY ASSESSMENT OF THE DELMARVA

PENINSULA, DELAWARE, MARYLAND, AND VIRGINIA

Robert J. Shedlock, Patrick J. Phillips, L. Joseph Bachman, and Pixie A. Hamilton - . . . - .

DEPARTMENT OF INTERIOR IRRIGATION DRAINAGE PROGRAM

RECONNAISSANCE STUDY OF KLAMATH BASIN REFUGE AREAS, CALIFORNIA AND OREGON

Stephen K. Sorenson and S.E. Schwarzbach

TRANSPORT OF ORGANIC CONTAMINANTS IN GROUND WATER BENEATH AN ABANDONED OIL REFINERY

Timothy B. Spruill

SETTLING PROPERTIES OF SUSPENDED SEDIMENT FROM THE MISSISSIPPI RIVER

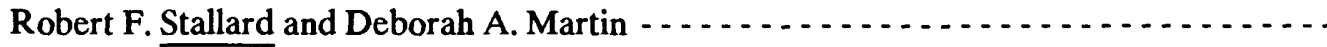

USING A GEOGRAPHIC INFORMATION SYSTEM TO RELATE HUMAN AND NATURAL FACTORS TO STREAM WATER QUALITY IN THE UPPER ILLINOIS RIVER BASIN IN ILLINOIS, INDIANA, AND WISCONSIN

Faith A. Stanke

BIOLOGICAL MONITORING OF STREAMS IN JEFFERSON COUNTY, KENTUCKY

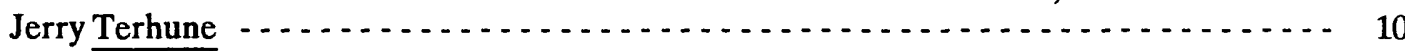

SOURCES OF ERROR IN FIELD SPECIFIC-CONDUCTANCE MEASUREMENTS

Kenneth Scott Turner

STATISTICAL ANALYSIS OF WATER QUALITY OF STORMFLOW AND BASE FLOW FOR STREAMS IN THE AUSTIN AREA, TEXAS

Jack E. Veenhuis $\ldots \ldots \ldots \ldots$

RESEARCH PLAN TO EVALUATE THE RELATIONS AMONG GROUND-WATER QUALITY, HYDROGEOLOGIC CONDITIONS, AND HUMAN ACTIVITIES IN THE NORTHERN ATLANTIC COASTAL PLAIN

Eric F. Vowinkel and Steven F. Siwiec

DISTRIBUTION OF TRACE METALS IN SEDIMENT AT PICATINNY ARSENAL, NEW JERSEY

Stephen A. Wilson and Paul H. Briggs

BOTANICAL COMMENTS ON TREES AS CHEMICAL RECORDERS OF

GROUND-WATER CONTAMINATION

Thomas M. Yanosky and Don A. Vroblesky 


\section{APPLICATION OF A WATER-QUALITY INDEX}

\author{
Eliane D. Abdala \\ Ministerio Da Ciencia E Tecnologia De Minas Gerais \\ Av. Jose Candido da Silveira, 2000 \\ Belo Horizonte-MG - 30000 - Brazil
}

\author{
Herman R. Feltz* \\ U.S. Geological Survey \\ Office of Water Quality \\ 412 National Center \\ Reston, Virginia 22092
}

\begin{abstract}
A water-quality index (WQI) is one means of summarizing waterquality measurements at a given site to permit a comparison of relative water quality at different locations on the same stream or river. In addition, a WQI permits comparison of water quality between rivers in the same hydrographic basin, and among rivers in different hydrographic basins. The principal advantage of a WQI is that the index is an objec-
\end{abstract}

tive multivariate function of the concentration of each individual constituent. Use of the WQI can help establish sampling frequency at stations as well as provide an early alert to changing conditions.

Based on the WQI calculated for the sampling station Ponte Nova do Paraopeba, Minas Gerais, Brazil, it would be desirable to continue operation at this sampling site with a frequency of at least sixteen samples per year. Based on the pattern of land and water use observed in the basin, analysis for chlorinated pesticides needs to be emphasized during the rainy season, and analysis of toxic metals emphasized during the dry season. Further use of the methodology developed for calculating the WQI for the Ponte Nova site is desirable for evaluating water-quality monitoring throughout Brazil.

*Presenting author.

\section{ABILITY OF MICROBIAL COMMUNITIES FROM A PRISTINE AQUIFER TO DEGRADE XENOBIOTIC COMPOUNDS}

\author{
C. Marjorie Aelion* \\ U.S. Geological Survey \\ Water Resources Division \\ 1835 Assembly Street, Suite 677A \\ Columbia, South Carolina 29201
}

\author{
Frederic K. Pfaender \\ University of North Carolina \\ Department of Environmental Sciences \\ and Engineering \\ Chapel Hill, North Carolina 27599-7400
}

This study examined the ability of the microbial community from a pristine aquifer near Lula, Oklahoma, to degrade a variety of organic compounds under aerobic conditions. Degradation and adaptation were monitored using ${ }^{14} \mathrm{C}$-radiolabeled substrates by measuring ${ }^{14} \mathrm{CO}_{2}$ production over time. Adaptation was defined functionally as an increase in the rate of mineralization of the ${ }^{14} \mathrm{C}$ radiolabeled substrates with exposure to the chemical.

Several patterns of microbial response to xenobiotic compounds were evident. For some compounds, such as chlorobenzene, 1,2,4-trichlorobenzene and toluene, limited mineralization (less than 0.5 percent) was detected during more than 8 months of incubation. Intermediate rates of biodegradation were observed for m-cresol, $\mathrm{m}$-aminophenol and aniline. A maximum of 10 to 15 percent of these radiolabeled compounds was respired during the 3 to 5 months of incubation. Phenol, ethylene dibromide and p-chlorophenol were rapidly mineralized, to a maximum of 20 to 35 percent within the first few weeks of incubation.
Of the compounds examined, only p-nitrophenol and m-nitrophenol elicited an adaptation response in the microbial community. The length of the adaptation period to p-nitrophenol varied from 1 to 6 weeks in different sediment samples. Adapted rates of biodegradation were rapid, and a maximum of 60 percent of the p-nitrophenol added was respired by the adapted community. These results suggest that community adaptation as well as mineralization rates are largely compound specific.

${ }^{*}$ Presenting author. 


\section{A COMPUTERIZED SYSTEM FOR THE DETECTION AND ANALYSIS OF LONG-TERM TRENDS IN WATER-QUALITY DATA}

\author{
Richard B. Alexander* \\ U.S. Geological Survey \\ Water Resources Division \\ Branch of Systems Analysis \\ 410 National Center \\ Reston, Virginia 22092
}

\author{
Terry L. Schertz and Dane J. Ohe \\ U.S. Geological Survey \\ Water Resources Division \\ 8011 Cameron Road, Building 1 \\ Austin, Texas 78753
}

On the basis of recent experiences obtained in several national and statewide U.S. Geological Survey water-quality investigations, a comprehensive set of data management and statistical computer programs has been developed for the detection and analysis of monotonic trends in censored and uncensored waterquality data. The computer programs are designed for the analysis of long-term, regularlycollected water-quality records. A parametric trend technique is used to estimate trends in censored constituents (those constituents where more than 5 to 10 percent of the observations are reported as less than a specified detection limit). The censored trend technique consists of a maximum-likelihood pro- cedure for estimating the parameters (intercept and slope) of a linear regression of constituent concentration on time. A nonparametric test for trend, the Seasonal Kendall test, is used for constituents designated as uncensored. Estimates of moments and percentiles are provided as part of the censored and uncensored statistical procedures. The uncensored trend procedure provides for the removal of the effects of seasonal and flow variations on water-quality concentrations. Adjustment for seasonal effects requires that the user specify seasons from information about the sampling frequency at individual stations or from knowledge of water-quality processes in the study area. Flow dependence in the water-quality data is removed prior to trend testing by performing regressions of constituent concentration on dishcarge. The residuals (flow-adjusted concentrations) from the "best" regression model are then tested for time trend. The "best" concentrationflow regression model may be determined by the user or selected according to an automated evaluation of the model fit. Trend results may be calculated for any specified period of the record. For uncensored constituents, trend results are computed for individual seasons, flow-adjusted values, and unadjusted values. Mapping, plotting, and tabling routines are available to examine the data and results.

*Presenting author.

\section{PRESIDENT'S INITIATIVE ON ENHANCING WATER QUALITY}

\author{
C. R. Amerman \\ U.S. Department of Agriculture \\ Agricultural Research Service \\ Office of the Administrator \\ Washington, DC 20250
}

have developed a coordinated five-year plan to honor that commitment. Building on an interagency resource base of about $\$ 226$ million, a \$64 million increase was proposed to take effect in Fiscal Year 1990. With a whole-system emphasis, Agriculture will work on the development and demonstration of agricultural management practices designed to avoid water-quality degradation. Commerce will monitor the effects of agricultural runoff on coastal and inland waterways. EPA will work to improve farmer's and rancher's understanding of agriculture's obligations as stewards of water quality. Interior will measure and monitor water quality. 


\title{
FIELD MEASUREMENTS OF DISSOLVED NITROGEN AND OXYGEN IN GROUND WATERS OF THE BLACK HILLS AREA, SOUTH DAKOTA
}

\author{
Mark T. Anderson* \\ U.S. Geological Survey \\ Water Resources Division \\ Room 237, 515 9th Street \\ Rapid City, South Dakota 57701
}

\author{
Janelle M. Williams \\ CH2M Hill \\ P.O. Box 2090 \\ Milwaukee, Wisconsin 53201-2090
}

The concentration and percent saturation of dissolved nitrogen and oxygen were determined at 26 sites during a one-year period for the purpose of investigating the occurrence and process of nitrogen gas supersaturation in aquifers underlying the Black Hills area of South Dakota. The waters tested were drawn from wells or springs that discharge from the Madison, Minnelusa, and Deadwood Formations. Mean percent saturation ranged from 105.9 to 122.5 (14.4 to 20.1 milligrams per liter) for nitrogen and from 4.6 to 119.9 ( 0.5 to $\mathbf{1 2 . 4}$ milligrams per liter) for oxygen. The isotopic ratios of $\mathrm{N}^{15} / \mathrm{N}^{14}$ range from a $\delta^{15} \mathrm{~N}$ of +0.2 $\%$ to $+0.8 \%$, which suggests that the nitrogen is atmospheric in origin rather than resulting from denitrification within the aquifers.

The concentrations of nitrogen gas were measured using a portable field instrument known as a Weiss
Saturometer. The analytical results obtained in the field with the saturometer were compared with those obtained in the laboratory using gas chromatography; the results were found to be the same (within the accuracy of measurements). Field measurement of dissolved nitrogen in water is now possible for a variety of applications.

*Presenting author.

\section{USDA RESEARCH PLAN FOR WATER QUALITY}

\author{
Loris E. Asmussen \\ U.S. Department of Agriculture \\ Agricultural Research Service \\ Southeast Watershed Research Laboratory \\ P.O. Box 946 \\ Tifton, Georgia 31793
}

The use of agricultural chemicals has steadily increased since World War II. Now roughly 330 thousand tons of pesticides and 10.6 million tons of $\mathrm{N}$ as commerical fertilizer and $\mathbf{1 0}$ million tons through manures, crop residues, rainfall, and biological fixation are applied to agricultural crops yearly. With this increased use of chemicals, public concern has also increased. Both surface and subsurface water quality is now a major issue as shown by both Federal and State legislation. Major legislation was initiated with the U.S. Federal Water Pollution Control Act of 1972 (P.L. 92-500) which set the goal "to restore and maintain the chemical, physical, and biological integrity of the nation's waters." Since that time other major legislation has been passed with the last being the 1987 Amendment of the 1977 Clean Water Act. Undoubtedly other legislation will be enacted in FY 89 or 90 . The United States Department of Agriculture has, during this period, also increased its emphasis on education, extension, and research. Emphasis during the 70's was on surface water quality, and during the 80's emphasis was placed on the effects of agricultural management on ground water quality recharge.
The goal of the department is to develop systems to manage chemicals within the plant rootzone. This will require the cooperation of extension, education and research personnel to "maintain and manage the environmental and natural resources associated with agriculture." The USDA 1989 Research Plan for Water Quality, and the ARS Strategic Ground Water Plan, which contains two parts, Pesticides and Nitrates, will be reviewed. The goals, objectives, elements, and priorities are reviewed and the relationship to other U.S. Government agencies discussed. 


\author{
Mary Jo Baedecker and Isabelle Cozzarelli* \\ U.S. Geological Survey \\ Branch of Regional Research, NR \\ MS 431 National Center \\ Reston, Virginia 22092
}

\author{
Don Goerlitz \\ U.S. Geological Survey \\ Branch of Regional Research, WR \\ 345 Middlefield Road, MS 421 \\ Menlo Park, California 94025
}

\begin{abstract}
Volatile organic acids (molecular weight less than 200) are produced as intermediates by microbial processes in natural and contaminated organic-rich sediments. Aliphatic acids, found in concentrations of up to 470 milligrams per liter, were identified in several aquifers that are anoxic and have high concentrations of dissolved organic carbon, iron, manganese, methane, and carbon dioxide. These acids alter the geochemistry of the water, affect the solubility of minerals, complex with metals, and may cause
\end{abstract}

spreading of a contaminant plume because of their solubilities.

At one site, aliphatic and aromatic acids were found in anoxic ground water near an oil lens. Analysis of distilled water equilibrated with oil indicated that the acids were not original components of the oil. The concentration of organic acids near the oil source was 3.1 milligrams per liter; these acids contain 6.5 percent of the dissolved organic carbon. Their concentrations decreased to less than 1 percent of the organic carbon 20 meters downgradient from the source. The alkyl benzoic acids identified in the ground water near the source were related structurally to alkyl benzenes from the oil. These acids most likely were produced within the plume during degradation of the dissolved hydrocarbons. Microcosm experiments were undertaken to investigate further the degradation of hydrocarbons and formation of acids as intermediates under controlled conditions.

*Presenting author.

\section{NITRATE IN GROUND WATER AT A FARM IRRIGATED WITH TREATED SEWAGE AND INORGANIC FERTILIZERS, TALLAHASSEE, FLORIDA}

\author{
Marian P. Berndt \\ U.S. Geological Survey \\ Water Resources Division \\ Suite 3015 \\ 227 North Bronough Street \\ Tallahassee, Florida 32301
}

Secondary-treated sewage and inorganic fertilizers have been applied to fodder crops at a 1,840 -acre farm near Tallahassee since 1980. The site is irrigated in center-pivot tracts and underlain by a surficial aquifer, consisting of sand and silt with some clay layers, and by the Upper Floridan aquifer, consisting of carbonate rocks. Nitrate concentrations in ground water have increased since 1981. Comparison of water from the unsaturated zone with ground water showed that conversion of ammonia and organic nitrogen to nitrate was complete before the nitrogen-enriched water reached the water table.
Nitrate enrichment occurs principally in water from shallow wells directly beneath irrigated areas. Samples from wells less than 100 feet deep located within irrigated areas had a mean nitrate concentration of 6.8 milligrams per liter (as nitrogen), compared to 0.59 milligram per liter for samples from wells of similar depths located outside irrigated areas. Samples from wells greater than 100 feet deep did not vary as much and had a mean nitrate concentration of 1.0 milligram per liter.

Nitrogen isotope ratios, $\delta^{15} \mathrm{~N}$, for nitrate in ground water were used to determine the relative proportion of nitrate contributed by the sewage and by the fertilizers. The range in $\delta^{15} \mathrm{~N}$ values at the farm site fell between established ranges for animal waste and inorganic sources of nitrogen, whereas the range in $\delta^{15} \mathrm{~N}$ values at another site irrigated with treated sewage, but not fertilized, was closer to the range expected for animal waste. Statistical analyses showed a significant difference (probability value of .0001) in $\delta^{15} \mathrm{~N}$ values between the two sites, indicating that nitrate in ground water at the farm site cannot be attributed solely to the sewage. 


\author{
Stephen F. Blanchard \\ U.S. Geological Survey \\ 102 East Main Street, 4th Floor \\ Urbana, Illinois 61801
}

and internally consistent. Each constituent was then evaluated for its occurrence and spatial distribution in the study area. When appropriate, the constituent concentrations were compared to ambient water-quality criteria, analyzed for long-term temporal trends, regressed against discharge to develop mass-transport estimates, and related to human and natural factors to determine causes for the observed conditions and trends.
One result of the analysis showed that certain constituents, such as counts of fecal indicator bacteria, consistently exceeded waterquality criteria throughout the study area. Significant trends were detected throughout the basin for several water-quality characteristics such as $\mathrm{pH}$, dissolvedsulfate concentration, and bacteria counts. Mass-transport estimates were used to determine watershed yields. A gross-constituent loading budget was then used to determine the relative contributions from point and nonpoint sources.

and screening of the data to insure that they were technically sound

\section{COMBINATION OF SURFACE GEOPHYSICS AND BOREHOLE MEASUREMENTS TO DEFINE GROUND WATER POLLUTION PLUMES}

\author{
Istvan Bogardi*, William E. Kelly, \\ and Wayne Woldt \\ Civil Engineering Department \\ W 348 Nebraska Hall \\ University of Nebraska-Lincoln \\ Lincoln, Nebraska 68588-0531
}

\author{
Andras Bardossy \\ Intstitute fur Hydrologie und Wasserwirtschaft \\ Universitat Karlsruhe (TH) \\ Kaiserstr 12 \\ D-7500 Karlsruhe 1 \\ West Germany
}

The purpose of the paper is to show how fast, relatively inexpensive, but less accurate surface geoelectric measurements can be combined with traditional borehole measurements to estimate the degree and extent of ground-water contamination. The methodology is illustrated on a USGS documented low-level radioactive plume at Wood River Junction, Rhode Island. Main steps of the application include:
1. Two-layer and three-layer geophysical models are developed to consider geoelectrical measurement data in addition to other geological information to estimate specific conductance of the ground water.

2. An enhanced geostatistical software package is used to map specific conductances in 3-D. It is shown that although a similar pattern of the plume can be obtained from either source of information, the estimation error for the magnitude of the plume is quite high.

3. Various methods are used to combine the above two types of information (well data and geophysics). It is shown that the error of the combined map is smaller than the error corresponding to any of the maps developed from separate information.

*Presenting author. 


\section{GEOCHEMISTRY OF IRON IN A SAND DUNE AQUIFER USED FOR MUNICIPAL AND INDUSTRIAL WATER SUPPLY NEAR COOS BAY AND NORTH BEND, OREGON}

\author{
Gilbert C. Bortleson \\ U.S. Geological Survey \\ 1201 Pacific Avenue, Suite 600 \\ Tacoma, Washington 98402
}

\begin{abstract}
Geochemical processes controlling dissolved iron concentrations were studied in a sand dune aquifer used for water supply. Large concentrations of dissolved organic compounds and carbon dioxide produced from the root zone and litter of lodgepole pine forest increase the capacity of shallow ground water to dissolve iron-bearing minerals. Forest cover causes a greater amount of iron to be released to shallow ground water than does bare sand or herbaceous plant cover, even though $\mathrm{pH}$ is similar (pH 5.6 to 6.7)
\end{abstract}

in all areas. Dissolved iron concentrations are largest $(2,500$ to 30,000 micrograms per liter) in shallow ground water that has infiltrated areas of lodgepole pine forest and smallest (10 to 970 micrograms per liter) in shallow ground water that has infiltrated bare sand. In contrast to shallow ground water beneath forested areas, water from most deeper parts of the aquifer has concentrations of dissolved iron that range from a few tens to a few hundreds of micrograms per liter. Large carbonate-bicarbonate concen- trations from dissolution of marine shell fragments causes precipitation of siderite $\left(\mathrm{FeCO}_{3}\right)$ and removal of dissolved iron.

These same geochemical processes in the shallow ground water are believed to be active along other parts of the West Coast and possibly in areas of pine silviculture in the southern States. If conditions are right, gross nonpoint iron contamination of ground water caused by coniferous reforestation may be occurring over large areas.

\section{HYDROCARBON CONTAMINATION WTHIN THE UPPER FLORIDAN AQUIFER IN ORLANDO, FLORIDA}

The Upper Floridan aquifer in the Orlando, Florida area is overlain by more than 100 feet of confining material; the top of the aquifer is about 200 feet below land surface. Despite this apparent protection from surface contamination, a concentration of 200 micrograms per liter of benzene was found in a well tapping the aquifer. Subsequent sampling of seven other wells indicate that a hydrocarbon plume that is almost 1 mile long from west to east, and about 0.5 mile wide from north to south exists in the aquifer.

Hydrocarbons in water samples of eight wells in the Upper Floridan aquifer include aromatic hydrocarbons such as benzene, ethyl

\author{
L. A. Bradner \\ U.S. Geological Survey \\ 224 West Center Street, Suite 1006 \\ Altamonte Springs, Florida 32714
}

benzene, and xylenes, and a variety of polycyclic aromatic hydrocarbons, such as acenaphthylene, acenaphthene, anthracene, fluoranthene, fluorene, naphthalene, phenanthrene, phenols, and pyrene. Additional compounds that have been tentatively identified include thiophene, benzo(b)thiophene isomers, indenes, naphthalene isomers, fluorene isomers, phenanthrene isomers, and other compounds associated with coal tar.

Highest concentrations exist near the site of a defunct manufacturedgas plant that operated from about 1888 to the late 1950 's. Historical records show that a permit was issued in 1940 for a drainage well for disposal of condenser water at the site. Processing waste laden with miscible hydrocarbons may have entered the Upper Floridan aquifer through this well or another well at the plant.

Benzene and acenaphthene were detected in fairly high concentrations throughout the plume. Tentatively identified compounds, such as thiophene, benzo(b)thiophene, and isomers of the polycyclic aromatic hydrocarbons also remained above detection limits. The decrease of most volatile hydrocarbons downgradient from the plant may reflect dilution by aquifer water or sorption of the specific compound. Volatilization of these compounds in the confined aquifer is improbable. 


\section{A COMPARISON OF ANALYTICAL TECHNIQUES USED FOR THE DETERMINATION OF VOLATILE AND SEMIVOLATILE ORGANIC CONTAMINANTS IN GROUND WATER}

\author{
Doug Cain* \\ U.S. Geological Survey \\ 503 N. Main, Suite $207 \mathrm{~W}$ \\ Pueblo, Colorado 81003 \\ Daniel T. Chafin \\ U.S. Geological Survey \\ 503 N. Main, Suite $207 \mathrm{~W}$ \\ Pueblo, Colorado 81003 \\ Lorne F. Isabelle \\ Oregon Graduate Center \\ 19600 N.W. Von Neuman Drive \\ Beaverton, Oregon 97006 \\ Jacob Gibs \\ U.S. Geological Survey \\ Mountain View Office Park \\ 810 Bear Tavern Road, Suite 206 \\ W. Trenton, New Jersey 08628 \\ Ronald Baker \\ U.S. Geological Survey \\ Mountain View Office Park \\ 810 Bear Tavern Road, Suite 206 \\ W. Trenton, New Jersey 08628
}

\author{
James F. Pankow \\ Oregon Graduate Center \\ 19600 N.W. Von Neuman Drive \\ Beaverton, Oregon 97006
}

\author{
William T. Foreman and Steven D. Zaugg \\ U.S. Geological Survey \\ National Water-Quality Laboratory \\ 5293 Ward Road-B \\ Arvada, Colorado 80002 \\ Michael J. Liszewski \\ U.S. Geological Survey \\ Federal Building, Room 269 \\ 400 South Clinton Street \\ Iowa City, Iowa 52244
}
Brooke F. Connor and Marilyn G. Werner
U.S. Geological Survey
National Water-Quality Laboratory
5293 Ward Road-B
Arvada, Colorado 80002

\author{
Roderick F. Ortiz \\ U.S. Geological Survey \\ 503 N. Main, Suite $207 \mathrm{~W}$ \\ Pueblo, Colorado 81002
}

\begin{abstract}
A laboratory and field comparison of eight techniques used for the analysis of volatile and semivolatile organic contaminants in ground water was made as part of the National Water-Quality Assessment Program and the Toxic Waste--Ground-Water Contamination Program of the U.S. Geological Survey. The following techniques were evaluated: (1) Field headspace analysis using a portable gas chromatograph with a photoionization detector; (2) purge and trap followed by gas chromatography with tandem Hall and photoionization detectors; (3) purge and trap followed by gas chromatography with mass
\end{abstract}

spectrometry; (4) purge with whole-column cryotrapping followed by gas chromatography with mass spectrometry; (5) closed-loop stripping followed by gas chromatography with mass spectrometry; (6) continuous liquid-liquid extraction followed by gas chromatography with mass spectrometry; (7) field adsorption onto a Tenax cartridge followed by thermal desorption and gas chromatography with mass spectrometry; and (8) field extraction onto a $\mathrm{C}-18$ bonded phase cartridge followed by solvent extraction, and solvent removalthermal desorption and gas chromatography with mass spectrometry.

The laboratory comparison of the eight techniques involved determination of the mass of each target compound injected into the gas chromatograph by using data from recovery studies, volume of sample analyzed, and percent of the sample extract that was injected. Included in the field comparison of the eight techniques were collection and analysis of 21 random-order split samples from the Fountain Creek alluvial aquifer in Colorado and the upper glacial aquifer on Long Island, New York, and extensive analyses of triplicate samples, blanks, and field spikes. 
Study results indicate that the tecliniques varied in the following: (1) Their applicability for analysis of different classes of organic contaminants; (2) the mass of the various target compounds injected into the gas chromatograph; (3) precision of replicate analyses; (4) susceptibility to blank contamination; and (5) ease of application in the laboratory and field.

*Presenting author.

\section{GEOCHEMICAL CONSEQUENCES OF RAPID SEDIMENTATION IN RESERVOIR LAKES RECEIVING MINING WASTES}

\author{
Edward Callender* \\ U.S. Geological Survey, WRD \\ Northeast Region, NRP \\ M.S. 432, National Center \\ Reston, Virginia 22092
}

\author{
Walter H. Ficklin \\ U.S. Geological Survey, GD \\ Branch of Geochemistry \\ M.S. 973, Denver Federal Center \\ Denver, Colorado 80225
}

Sedimentation rates in natural lakes exhibit a general range from 0.01 to $0.6 \mathrm{~cm}$ (centimeters) per year. By comparison, man-made reservoir lakes exhibit a range from 2 to $180 \mathrm{~cm}$ per year. In many natural lakes, steady-state diagenesis occurs whereby the sediment-water interface system may approach equilibrium. This results in the production of interstitial-water chemistry profiles that are qualitatively similar upon repetitive sampling from one year to the next. In environments where high rates of sedimentation prevail, there is insufficient time for the sedimentwater interface environment to equilibrate. Interstitial-water profiles of iron and arsenic from sediment cores in Lake Oahe, South Dakota suggest that physical advective processes (sedimentation) can modify the effects of molecular diffusion.

Rapid, variable sedimentation rates also can exert a pronounced influence on solid-phase geochemical distributions. The fine-scale distribution of cesium-137 in a two-meter core from Lake Oahe allows for the detailed reconstruction of sediment and element fluxes to a lacustrine environment that is receiving mining waste. The heavymetal (cadmium, lead, zinc) distribution in dated sediment cores from Pueblo Reservoir, south-central Colorado shows peak concentrations that correspond to metal discharges from Leadville mines during 1985 and 1983. These peaks would not be readily discernible in natural lakes where slow sedimentation rates tend to integrate the river input of metals.

*Presenting author.

\section{COMPARISON OF SOLUTE COMPOSITION OF PRECIPITATION AND DECIDUOUS AND CONIFEROUS THROUGHFALL IN A PIEDMONT WATERSHED}

\author{
Rosanna Cappellato \\ Biology Department \\ Emory University \\ Atlanta, Georgia 30322
}

Samples of throughfall from adjacent deciduous and coniferous canopies and of precipitation were collected at a watershed in the Georgia Piedmont for one year beginning in November 1987. A comparison of throughfall solute fluxes for 32 collectors split evenly between canopy types for 14 storms indicated different chemical interactions of both vegetation types with precipitation. For all 14 storms, the total sulfate deposition derived from the sum of the average deposition for each storm, was higher in throughfall from the deciduous canopy $\left(21.0 \mathrm{meq} \mathrm{m}^{-2}\right)$ and the coniferous canopy $(15.3$

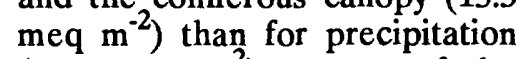
$\left(9.1 \mathrm{meq} \mathrm{m}^{-2}\right)$. Most of the throughfall sulfate flux in the deciduous canopy occurred during the growing season from May through October. The differences between the throughfall and precipitation sulfate fluxes were attributed mainly to the washoff of acidic sulfur particles and gases that had accumulated in the canopies during the dry period prior to each storm. The canopies reacted differently, however, with dry deposition. The acidity of the 
precipitation $(\mathrm{pH}=4.40)$ was partially neutralized as it passed through the deciduous canopy ( $\mathrm{pH}$ 4.87) whereas it increased as it passed through the coniferous canopy $(\mathrm{pH}=4.27)$. Differences in the chemical interactions of both canopy types also were reflected in much higher fluxes of calcium, magnesium, and potassium in the deciduous throughfall than in the coniferous throughfall. Exchange of hydrogen for base cations may have contributed to the net neutralization by the deciduous canopy.

\section{STATISTICAL COMPARISON OF TEMPORAL AND SPATIAL VARIABILITY IN WATER QUALITY AT WELLS IN FIVE LAND-USE AREAS OF NASSAU AND SUFFOLK COUNTIES, LONG ISLAND, NEW YORK}

\author{
Stephen J. Cauller \\ U.S. Geological Survey \\ 5 Aerial Way \\ Syosset, New York 11791
}

Water-quality data collected at 90 shallow water-table wells from June 1987 to October 1987, in five study areas that were delineated according to predominant land use and sewering practices, were compared with data from one control well within each study area. The control wells were sampled monthly from June 1987 to December 1988 to quantify temporal variations in ground-water quality and to compare temporal and spatial variability statistically. Exploratory data analysis of concentrations of major inorganic constituents and field characteristics ( $\mathrm{pH}$, specific conductance, water temperature, dissolved-oxygen concentration) indicates smaller variability in concentration ranges of nearly all constituents at each control well than among the corresponding 15 - or 20 -well population within each study area. Tukey's honest significant difference test of ranked constituent concentrations indicates either identical or overlapping populations at the 95 percent confidence level for nearly all inorganic constituents and field-measured characteristics between each control well and its corresponding studyarea well population. Exceptions were noted at the control well within the undeveloped study area for sodium and chloride, which have statistically significant higher median concentrations [ 61.5 and $97.5 \mathrm{mg} / \mathrm{L}$ (milligrams per liter), respectively] than those in the study-area well population ( 5 and $8.3 \mathrm{mg} / \mathrm{L}$, respectively) and an order of magnitude larger degree of variability in concentration ranges. Statistically significant higher median water temperature and lower median dissolvedoxygen concentrations than those in the study area well population also were observed in this well. These results are attributed to influxes from a nearby roadside storm-water drain. The control well in the agricultural study area had statistically significant higher median concentrations of calcium, magnesium, sulfate and nitrate than the corresponding study-area well population; this is attributed to its immediate proximity to agricultural land.

\section{DEFINITIONS FOR THE INTERPRETATION OF ANALYTICAL RESULTS FOR RADIONUCLIDES OF ENVIRONMENTAL CONCERN}

\author{
L. DeWayne Cecil \\ U.S. Geological Survey \\ Idaho National Engineering Laboratory \\ P.O. Box 2230 \\ Idaho Falls, Idaho 83403
}

Numerous definitions for a minimum detectable concentration for radionuclides lead to inconsistent interpretations of analytical results. A critical level and a minimum detectable concentration must be defined to make a decision of detection or nondetection based on analytical instrument signals for paired samples consisting of a target sample and prepared blank. The critical level is the level of radioactivity at which instrument signals for the paired samples are 
statistically different. The minimum detectable concentration is the concentration that will yield a sufficiently large instrument signal to make the correct decision for detection or nondetection most of the time.

Radionuclide concentrations generally are reported with an estimated sample standard deviation, $\sigma$, that is based on random and systematic errors inherent in measuring radioactive decay. Radionuclide concentrations that equal $1.6 \sigma$ represent measurements at the critical level.
There is a 95 percent probability that a radionuclide has not been detected at concentrations equal to $1.6 \sigma$.

The minimum detectable concentration may be determined after the critical level of $1.6 \sigma$ has been established. Radionuclide concentrations that equal $3 \sigma$ represent measurements at the minimum detectable concentration. There is a 95 percent or more probability that the target radionuclide has been detected at measured concentrations of $3 \sigma$ or greater.
These definitions are an extension of a method proposed by L.A. Currie (1984, Lower limit of detection: definition and elaboration of a proposed position for radiological effluent and environmental measurements: U.S. Nuclear Regulatory Commission, NUREG/CR-4007, 139 p.). The critical level and minimum detectable concentration for radionuclides aid in the interpretation of analytical results and do not represent absolute concentrations which may or may not have been detected.

\section{MEASURING HYDROGEN CONCENTRATIONS IN GROUND WATER: A TOOL FOR EVALUATING BACTERIAL PROCESSES IN DEEP AQUIFER SYSTEMS}

\author{
Francis H. Chapelle* \\ U.S. Geological Survey \\ 1835 Assembly St., Suite 677A \\ Columbia, South Carolina 29201
}

\author{
Derek R. Lovley \\ U.S. Geological Survey \\ National Center, Mail Stop 432 \\ 12201 Sunrise Valley Drive \\ Reston, Virginia 22092
}

Two novel techniques were used to measure concentrations of dissolved hydrogen gas $\left(\mathrm{H}_{2}\right)$ in ground water from a multi-layer aquifer system in South Carolina. The first technique, informally termed the "bubble strip" method, involves passing a continuous stream of water through a $250 \mathrm{~mL}$ (milliliter) gas-sampling bulb containing a $10 \mathrm{~mL}$ bubble of nitrogen gas. Hydrogen present in the water is "stripped" into the gas phase until equilibrium is achieved ( $\sim 4$ bulb volumes). The bubble is then withdrawn and analyzed for $\mathrm{H}_{2}$ using a gas chromatograph equipped with a reduction gas detector. The second technique, termed the "diffusion" method, uses teflon tubing ( $5 \mathrm{~mL}$ volume) equipped with sampling valves coiled around a PVC cylinder. The tubing is filled with nitrogen, lowered down a well to the screened interval, and $\mathrm{H}_{2}$ allowed to diffuse from the ground water into the $\mathrm{N}_{2}$ gas. At the end of an equilibration period (at least 24 hours) the tubing is withdrawn from the well and the gas analyzed for $\mathrm{H}_{2}$. When applied to the same wells, the bubble strip and diffusion methods give hydrogen concentration measurements that agree within 10 percent.

These techniques were used to quantify $\mathrm{H}_{2}$ concentrations in ground water at two well-cluster sites, with PVC-cased wells screened in four distinct aquifers at each site, in the coastal plain of South Carolina. The lower aquifer in the Pee Dee formation, which exhibited evidence of ferric iron reduction, had $\mathrm{H}_{2}$ concentrations in the 0.1 to 0.2 nanomolar range. The upper aquifer in this unit was characterized by active sulfate reduction and had $\mathrm{H}_{2}$ concen- trations in the 1 to 2 nanomolar range. Finally, a well screened just below an organic-rich claystone and which showed active methanogenesis had $\mathrm{H}_{2}$ concentrations in the 10 nanomolar range. The observed $\mathbf{H}_{2}$ concentration ranges for iron reduction, sulfate reduction, and methanogenesis are virtually identical to those observed in studies of aquatic sediments and are consistent with ranges predicted by theoretical considerations. These results show that $\mathrm{H}_{2}$ concenerations are a useful tool in documenting the predominant electron accepting processes in ground-water systems as well as in aquatic sediments. As such, measuring $\mathrm{H}_{2}$ concentrations in ground water may give valuable insight into the presence or absence of particular bacterial processes in deep aquifer systems. *Presenting author. 


\author{
David A. Chin \\ Department of Civil and Architectural Engineering \\ University of Miami \\ Coral Gables, Florida 33124
}

Significant progress has been made in developing guidelines for monitoring program design, statistical methods for analyzing ground-water data, and models for predicting the movement of contaminants in ground water. Within the framework of these developments, an assessment now needs to be made of the high quality data collected in specific projects, with the objective of identifying phenomena which may be present at a wide variety of locations, and that could significantly affect the conclusions drawn from a given data set. For example, data collected at several sites on the natural spatial and temporal variability of chemical parameters could significantly affect the confidence limits that we assign to a few measurements at an isolated site. In this study, water-quality measurements at a dense array of monitoring wells are reported and analyzed. The results show that the spatial variance of the major waterquality parameters, over distances on the order of $20 \mathrm{~m}$, significantly exceed the temporal variance of any of the wells. Furthermore, it is shown that statistical properties of the measured data, such as trend, normality, log-normality, seasonality, and auto-correlation, are seldom homogeneous even over relatively small length scales. These results illustrate the limitations in characterizing large areas based on measurements from a single monitoring well. The use of statistical techniques to analyze data from a detection monitoring study are illustrated. It is shown that these quantitative techniques may be used successfully to isolate water-quality impacts.

\title{
DELINEATION OF FACTORS RELATED TO THE OCCURRENCE OF 1,2-DIBROMOETHANE IN GROUND WATER, CENTRAL FLORIDA
}

\author{
Anne F. Choquette*, Brian G. Katz, William S. Pendexter, and \\ Miguel A. Orona \\ U.S. Geological Survey \\ 227 N. Bronough Street, Suite 3015 \\ Tallahassee, Florida 32301
}

A large ground-water quality data base for the nematicide 1,2-dibromoethane (EDB) is being used to evaluate methods for regional water-quality assessment as part of the U.S. Geological Survey pilot National WaterQuality Assessment Program. The EDB network in Florida represents one of the most densely sampled regional-scale networks in the United States. Additionally, detailed historical records on EDB application in the citrus areas document the locations, methods, dates of applications, and quantities of EDB applied. EDB had been applied for at least 20 years before ground water was sampled for EDB. In citrus- production areas of central Florida, EDB in ground water has exceeded concentrations of 100 micrograms per liter, and continues to be detected 6 years after the last known application.

To understand the factors affecting EDB concentrations in ground water, two approaches were used and compared. EDB concentrations in wells were statistically related to potential controlling factors in regionalscale study areas of 50 to 200 square kilometers where more than 600 wells had been sampled. These factors included distance along ground-water flow paths between EDB application sites and wells, amounts and timing of EDB applications, antecedent precipitation and soil temperature, well construction characteristics, and chemical and physical properties of soils underlying application sites. Concurrently, mass-balance modeling was used to quantify selected biogeochemical processes controlling the fate of EDB in the subsurface in local ground-water flow systems for areas less than 5 square kilometers. Consistency in controlling factors and specific effects of these factors were evaluated by contrasting results between regional-scale areas and results from the statistical and mass-balance modeling.

"Presenting author. 


\title{
EFFECTS OF ACID PRESERVATION ON THE CONCENTRATIONS OF VOLATILE ORGANIC COMPOUNDS IN NATURAL WATERS
}

\author{
Brooke F. Connor*, Mark W. Sandstrom, and Donna Rose \\ U.S. Geological Survey \\ National Water Quality Laboratory \\ 5293 Ward Road \\ Arvada, Colorado 80002
}

Many procedures for the analysis of volatile organic compounds (VOCs) by purge-and-trap gas chrom at ograph y/mass spectrometry (PT/GC/MS) include the use of hydrochloric acid $(\mathrm{HCl})$ added in the field as a preservative. However, such procedures occasionally cause losses of toluene and toluene-d8 surrogate spikes and formation of halogenated artifacts in $\mathrm{HCl}$ preserved samples. In this study the effects of acid preservation and free chlorine on the concentration of 60 VOCs were analyzed. Reagent water and natural water samples were preserved with $\mathrm{HCl}$ and sodium bisulfate to compare the effects of these preservatives. The effect of free chlorine on preserved and unpreserved samples was also compared. All unpreserved samples were analyzed for dissolved organic carbon, $\mathrm{pH}$, conductivity, chloride, and bromide. The results indicate that recoveries were greater than
80 percent for most of the VOCs in samples stored for 7 days at $4{ }^{\circ} \mathrm{C}$ (degree Celsius) either unpreserved or treated with sodium bisulfate. In $\mathrm{HCl}$ preserved samples, recoveries were significantly lower for 21 VOCs. The presence of halogenated artifacts in the $\mathrm{HCl}$ preserved samples suggests that the low recoveries are the result of chemical degradation caused by the addition of $\mathbf{H C l}$.

*Presenting author.

\section{THE AMBIENT GROUND-WATER QUALITY MONITORING PROGRAM OF} FLORIDA

\author{
Rick Copeland \\ Florida Department of Environmental Regulation \\ 2600 Blair Stone Road \\ Tallahassee, Florida 32399-2400
}

In 1983 the Florida Legislature passed the Water Quality Assurance Act, a portion of which required The Department of Environmental Regulation (DER) to establish a Statewide Ambient Ground-Water Quality Monitoring Network. The two primary goals of the Ambient Program are to: (1) establish baseline ground-water quality and (2) detect and predict changes in the quality of ground water resulting from the effects of potential contamination sources.

The Ambient Network actually consists of two subnetworks: (1) the Background Network, designed to aid in defining background water quality and (2) the VISA (Very Intense Study Area) Network, designed to monitor the combined effects of land use and hydro- geology on ground-water quality. Data generated from the program will be statistically analyzed in order to establish baseline and background water quality and to predict future changes to it. This information should be helpful in land use and zoning decisions and as an aid in monitoring DER permitted facilities. 


\section{GEOCHEMICAL EVOLUTION OF GROUND WATER AT A SURFACE COAL MINE RECLAIMED WITH URBAN SEWAGE SLUDGE IN WESTERN PENNSYLVANIA}

\author{
Charles A. Cravotta III \\ U.S. Geological Survey-WRD \\ P.O. Box 1107 \\ Harrisburg, Pennsylvania 17108
}

Urban sewage sludge has been applied at a rate of about 60 tons per acre over the level surface of a reclaimed surface coal mine in western Pennsylvania (1) to promote the growth of grasses and legumes and (2) to reduce groundwater acidity. The mine spoil is as thick as 80 feet and consists of sandstone, siltstone, and shale fragments, plus coal waste that contains up to 17 percent total sulfur and 10 percent pyrite. Lush vegetation on sludge-treated spoil prevents erosion and sedimentation, promotes evapotranspiration (when growing), and depletes oxygen (when decaying). Pyrite oxidation and acidic drainage may be controlled by decreased oxygen content of recharge waters as a result of the sludge treatment.

Local variations in ground-water quality result from reactions with different minerals. Dissolved sulfur, manganese, and calcium generally increase downflow in the mine spoil and bedrock. However, dissolved iron, silicon, aluminum, sodium, and potassium generally approach limiting maximum concentrations, probably because of equilibrium with minerals such as goethite, quartz, kaolinite, gibbsite, and jarosite. The computer programs WATEQ4F and NEWBAL are used to compute chemical equilibrium and mass transfer, respectively, considering reactions such as the oxidation of pyrite; dissolution of carbonate and silicate minerals; and precipitation of gibbsite, goethite, jarosite, and other secondary minerals. Mass-transfer models indicate that extreme quantities of oxygen, up to 50 times greater than its aqueous solubility, are required to generate observed concentrations of dissolved sulfate from pyrite. Elevated sulfate and acidity in bedrock ground water underlying the mine spoil result partly from dissolution of secondary iron-sulfate minerals such as roemerite or coquimbite. These minerals were identified and probably were formed in aerated, stockpiled overburden during mining, and in the unsaturated mine spoil (near the water table) after reclamation. Roemerite and coquimbite not only are sources of iron, sulfate and acidity in acidmine drainage, but they are a convenient source of ferric iron ions, which can oxidize pyrite whether or not oxygen is available. The failure to reduce acidity and dissolved solids concentrations in ground water beneath the sludgetreated spoil results from the presence of ferric-sulfate minerals and the potential for lateral flow of gaseous and dissolved oxygen into the mine spoil from untreated zones. Convection of gaseous oxygen through the vadose zone of the spoil and adjacent bedrock must be eliminated to prevent acidforming reactions above the water table. The effectiveness of preventing the transport of oxygen into surface coal-mine spoil can be enhanced by backfilling overburden quickly and applying sewage sludge over the entire surface, especially on steep slopes of loose spoil.

\section{TISSUE-ANALYSIS COMPONENT OF THE NATIONAL WATER-QUALTTY ASSESSMENT PROGRAM}

Analysis of biological tissues is planned for the National WaterQuality Assessment (NAWQA) Program to determine the occurrence and spatial distribution

\author{
J. Kent Crawford \\ U.S. Geological Survey \\ Post Office Box 1107 \\ Harrisburg, Pennsylvania 17108
}

of selected trace elements and synthetic organic compounds, and to determine temporal trends in the tissue concentrations of these contaminants. The potential for human exposure to contaminants also will be investigated. These objectives will be met by conducting sampling in two stages during the three-year intensive 
phase of each individual NAWQA study; first a reconnaissance survey will be conducted to establish the occurrence of contaminants; then, a synoptic survey will be conducted to assess the spatial distribution and the potential for human exposure. At most stations, trends can be analyzed only after several sampling cycles, however, annual tissue sampling at two sites per study area during the six-year reduced-intensity phase of the NAWQA cycle will allow early detection of trends at these sites and may serve as an early warning of expected trends at other locations in the basin.

Mollusks, because of their relatively large size, sessile habits, and known ability to accumulate contaminants in their tissues, will be the organism of first priority to be used in tissue sampling. For organic contaminants, fish are second priority, followed by decapods and aquatic plants. For trace elements, the priority is the same, except that aquatic insects will be used in lieu of decapods. To insure that enough tissue is collected for analysis, a composite of 20 whole mollusks will comprise a sample. A composite of 10 whole fish will be used for analysis of synthetic organic chemicals while 20 fish livers will be used for trace elements. Fish fillets will be used to evaluate the potential for human exposure to contaminants. In 1989 and 1990, testing and evaluation of the plan will be conducted in the Upper Illinois River basin and the Yakima River basin during the pilot project phase of NAWQA.

\title{
SELENIUM IN SOILS AND VEGETATION AT THE KENDRICK RECLAMATION PROJECT AREA, WYOMING
}

\author{
James G. Crock*, R. C. Severson, and J. A. Erdman \\ U.S. Geological Survey \\ Denver Federal Center \\ Box 25046, Mail Stop 973 \\ Denver, Colorado 80225
}

In the 1930's, the Bureau of Reclamation began the Kendrick irrigation and drainage project in Natrona County, Wyoming. Approximately 24,000 acres near Casper, Wyoming has been under irrigation since about 1946 . The present study is concerned with defining the distribution of selenium in agricultural and native plants and soils of the Kendrick Reclamation Project Area. With this information, an evaluation can be made regarding the full extent of mobilization, transport, and concentration of selenium in soils and plants due to irrigation and drainage in the cultivated areas. The information on native plants and soils provides background information on the natural contribution of selenium and other trace elements.

Samples of uncultivated soils were collected from all 14 geologic units in the study area. When present, big sagebrush (Artenisia tridenata) was also collected. Sections in the study area where more than 40 acres was under irrigation were also sampled along with associated alfalfa (Medicago sativa). These samples of soil, alfalfa, and sagebrush were analyzed for their trace- and major-element contents. Analyses show elevated selenium levels in both alfalfa and sage, whereas both native and cultivated soils, in general, contain only typical selenium levels as compared to the baseline established for the soils of the Northern Great Plains. Large variability is seen on the local level for the vegetation, but not the soils.

*Presenting author 


\title{
WESTERN INVESTIGATIONS OF IRRIGATION-INDUCED WATER-QUALITY PROBLEMS
}

During the last several years there has been increasing recognition of the impacts of irrigation drainage water on human health and fish and wildlife resources. In 1983, the U.S. Department of the Interior discovered that elevated levels of selenium in the Kesterson Reservoir in California were causing waterfowl deaths, deformities, and reproductive failures. In other areas throughout the western States, high levels of other trace elements and pesticides
Jonathan P. Deason

Office of Assistant Secretary for

Policy, Budget and Administration

U.S. Department of the Interior

18th and C Street, NW

Washington, DC 20240

have been identified subsequently in water, sediment, plant and animal samples.

In response to this situation, the Interior Department initiated the National Irrigation Water Quality Program to identify areas where irrigation drainage water may be causing or has the potential to cause harmful effects. To date, 22 areas in 13 States have been identified where the Department believes problems may exist. Interdisciplinary teams of engineers and scientists are at work at these locations to evaluate the problems, conduct scientific investigations, and develop solutions.

The new Interior Department program is designed to respond to irrigation-induced water quality problems in a manner that protects our Nation's fish and wildlife resources while at the same time maintaining the viablity of irrigation projects in the western States.

\section{THE APPLICATION OF FUGACITY MODELS TO ASSESS CHEMICAL PARTITIONING IN WETLANDS}

\author{
Joseph J. Delfino* and Kathleen J. O'Neil \\ Department of Environmental Engineering Sciences \\ A.P. Black Hall \\ University of Florida \\ Gainesville, Florida 32611
}

Fugacity based models, originally devised by $D$. Mackay and S. Paterson, are evaluative models that assess the partitioning of chemicals among air, soil, water, sediment, suspended sediment and biota compartments in a defined environment. Fugacity models allow resource managers to predict the tendency of chemicals to move from one environmental compartment or phase to another based on physical-chemical properties of the chemical and the environment. Experiments were performed to assess the intercompartmental distribution of lindane, chlorpyrifos, naphthalene and chlorobenzene in microcosms utilizing materials taken from a cypress wetland in Florida. The response of the models to changes in various input parameters was also evaluated. The compounds showed high affinity for partitioning into the wetland detritus and had predicted persistence periods of several months. These results correlated with the findings of a companion study which quantified levels of chlorinated pesticides in aquatic sediments and wetland soils long after compound release had ceased.

' Presenting author. 


\section{RESULTS OF BIOLOGICAL UPTAKE TESTS, TOXICITY TESTS AND CHEMICAL ANALYSES OF WATER AND BOTTOM MATERIAL FROM BAYOU D'INDE AND THE LOWER CALCASIEU RIVER, LOUISIANA}

\author{
Charles R. Demas* and Dennis K. Demcheck \\ U.S. Geological Survey \\ Water Resources Division \\ P.O. Box 66492 \\ Baton Rouge, Louisiana 70896
}

\author{
Philip Crocker \\ U.S. Environmental Protection Agency \\ 1445 Ross Avenue \\ Dallas, Texas 75202
}

\section{George Morrison \\ U.S. Environmental Protection Agency \\ Environmental Research Laboratory \\ South Ferry Road \\ Narragansett, Rhode Island 02882}

The U.S. Geological Survey, U.S. Environmental Protection Agency, and the Louisiana Department of Environmental Quality conducted an intensive chemical and toxicological investigation of the water and bottom material in Bayou d'Inde and the lower Calcasieu River, La., during the week of June 20,1988. Data on the uptake of organic contaminants by the clam, Rangia cuneata, also were collected. The study was conducted to determine the usefulness of toxicity and uptake data in evaluating environmental implications of ambient chemical data.

The concentrations of most constituents in water in the study area were low with the exception of volatile organic compounds. Concentrations of chromium, cadmium, lead, mercury, and semi-volatile organic compounds were near or below levels of detection in the study area. In contrast, volatile organic compounds, such as bromoform, chloroform, and 1,2 dichloroethane, were found in high concentrations at several sites in Bayou d'Inde. Bromoform occurred in concentrations ranging from below levels of detection to 100 micrograms per liter.

Bottom material, in the study area, contained high concencompounds. Chromium, lead, and mercury in bottom material were detected in Bayou d'Inde; however, mercury was the only metal detected at levels approaching U.S. Environmental Protection Agency "Apparent Effects Threshold" of $0.41-2.1 \mu \mathrm{g} / \mathrm{g}$ (micrograms per gram). High concentrations of hexachlorobenzene $(630 \mu \mathrm{g} / \mathrm{g})$ and hexachlorobutadiene $(470 \mu \mathrm{g} / \mathrm{g})$ were found in bottom material in an area near the mouth of Bayou d'Inde.

Toxicity tests performed on water and bottom material from the study area confirmed chemical data. No trations of metals and organic toxicity was observed for the mysid shrimp, Mysidopsis bahia, and the inland silverside minnow, Menidia beryllina, exposed to ambient water at 18 sites for 7 days. In contrast, bottom material at several sites was toxic to the amphipod, Ampelisca abdita, during a 10-day test. Mortalities, as high as 100 percent, reflected the high chemical concentrations that were detected in bottom material samples.

At two sites in Bayou d'Inde, uptake tests using Rangia cuneata supported chemical and toxicity results for bottom material. Hexachlorobenzene and hexachlorobutadiene were found at elevated concentrations in Rangia placed in Bayou d'Inde for 35 days. Mortality of Rangia was similar to that of Ampelisca in the toxicity tests.

Chemical, toxicity, and uptake tests indicated the presence of toxic compounds which have stressed the benthic environment at some sites.

"Presenting author. 


\title{
EFFECTS OF AGRICULTURAL PRACTICES ON WATER CHEMISTRY IN AN UNCONFINED COASTAL PLAIN AQUIFER, SUSSEX COUNTY, DELAWARE
}

\author{
Judith M. Denver \\ U.S. Geological Survey \\ Water Resources Division \\ Federal Building, Room 1201 \\ 300 S. New Street \\ Dover, Delaware 19901
}

The unconfined Coastal Plain aquifer in Sussex County, Delaware is susceptible to nonpoint source contamination from applications of inorganic fertilizers, manures, and lime because of the shallow depth to the water table and the sandy nature of the sediments. Forty-one wells were installed in a predominantly agricultural watershed for collection of water-level data and water-quality sampling. The network includes nine clusters with wells screened at different depths in the aquifer.

The specific conductance of natural ground water is generally $70 \mu \mathrm{S} / \mathrm{cm}$ (microsiemens per centimeter at 25 degrees Celsius) or less, and sodium and bicarbonate are the major ions. Specific conductance ranges from about $100 \mu \mathrm{S} / \mathrm{cm}$ to greater than 500 $\mu \mathrm{S} / \mathrm{cm}$ in water samples affected by agricultural activities, and nitrate, calcium, and magnesium are the major ions. Bicarbonate concentration in water affected by agriculture commonly is lower than natural concentrations because bicarbonate reacts with hydrogen ions produced during nitrification.

Ground-water chemistry generally reflects local land use in near-surface parts of the flow system. Because cropland is interspersed with forested areas, zones of nearly natural water chemistry can overlie zones of water affected by agricultural practices downgradient from a forested area. Chemical stratification also occurs within zones affected by agricultural practices in response to differences in rates of fertilizer application for corn and soybean crops. Nitrate concentrations greater than 10 milligrams per liter as nitrogen are common throughout the aquifer in agricultural areas. A maximum nitrate concentration of 29 milligrams per liter was measured at the base of the aquifer, 80 feet below land surface.

\section{A DISSOLVED OXYGEN BUDGET FOR THE LOWER PATUXENT ESTUARY}

\author{
D. K. Domotor*, M. S. Haire, and N. M. Panday \\ Maryland Department of the Environment \\ Water Management Administration \\ 2500 Broening Highway \\ Baltimore, Maryland 21224
}

There have been indications that regions of the Chesapeake Bay containing anoxic waters have increased both spatially and temporally (EPA, 1983; Officer, et. al., 1984). Recently, there has been some speculation that a similar pattern has occurred in the lower reaches of the main tributaries of the Chesapeake Bay. Such an increase in hypoxic waters has been documented for the lower Patuxent Estuary (Heinle, et. al.); however, the cause of the increase is not fully understood.
Data from a very comprehensive 6-year monitoring and research program, some collected through cooperative efforts with the USGS, were analyzed in an attempt to describe and determine the cause of the dissolved oxygen problem in the Patuxent Estuary. Further, a water quality model was developed to show the relative importance of the various sources and sinks of dissolved oxygen in the most critical regions of the estuary.

The results show that (1) the most critical region of low dissolved oxygen is around Broomes Island about $25 \mathrm{~km}$ from the mouth of the
Patuxent, (2) the low dissolved oxygen in this region is primarily a localized problem caused by high sediment oxygen demand, and (3) the high sediment oxygen demand results from the accumulation of sediment and organic matter from within the estuary and from upstream sources. The results also show that a reduction in nutrient loadings from point and nonpoint sources will improve dissolved oxygen concentrations in the estuary by reducing the organic loading to the sediments.

* Presenting author. 
Susan G. Donaldson*, Glenn C. Miller, and W. W. Miller

Departments of Range, Wildlife and Forestry, and Biochemistry

University of Nevada, Reno

Howard Building, Room 154

Reno, Nevada 89557

The recovery of gasoline constituents from soil using a sonication/extraction method was evaluated using ten compounds characteristic of gasoline. The compounds examined included benzene, toluene, heptane, m-xylene, nonane, n-propylbenzene, 1,2,4-trimethylbenzene, n-butylbenzene, 1,2,4,5-tetramethylbenzene and dodecane. Variations of EPA extraction method 3550 were tested, using flame ionization gas chroma- tography with a $30 \mathrm{~m} \times 0.75 \mathrm{~mm}$ i.d. methyl silicone capillary column. In all cases, reducing total solvent extraction volume from $400 \mathrm{~mL}$ to $250 \mathrm{~mL}$ resulted in increased recoveries and shorted analysis time. Recovery of the gasoline constituents from wet soils was significantly lower than that from dry soils, but was improved by initial mixing of the soils with acetone, followed by the addition of methylene chloride. Recoveries were also dependent on the relative volatility of the constituents. Higher molecular weight compounds were recovered from dry soils at greater than $80 \%$ of the initial amount applied, while recoveries of benzene and heptane were generally less than $5 \%$. Using the optimum method, recovery of an unleaded gasoline from soil was $40 \%$ on a total petroleum hydrocarbon basis.

${ }^{*}$ Presenting author.

\section{NATIONAL PARK SERVICE WATER-QUALITY PROGRAM}

\author{
Nancy E. Driver \\ National Park Service \\ Water Resources Division \\ 301 South Howes Street \\ Room 353, \\ Fort Collins, Colorado 80521
}

The Water Resources Division of the National Park Service (NPS) presently is designing a national water-quality program which addresses significant threats to NPS surface- and ground-water resources and provides basic inventory information. The purpose of the water-quality program is to provide (1) a data base of basic information to permit effective protection and managment of water resources, (2) effective integration and coordination of technical, legal, and regulatory aspects of waterquality problems, and (3) capability to analyze and solve applied water-quality problems in the NPS.

The NPS is faced with a multitude of existing and potential surfaceand ground-water issues. The identified issues, of which 70 percent are related to nonpoint sources of pollution, are associated with anthropogenic causes located both inside and outside of parks. Inventory and monitoring programs are being developed to quantify baseline water-quality conditions, to detect changes from baseline conditions, and to identify causes of such changes. Waterquality monitoring activities are designed and managed to ensure the quality and utility of the data gathered. Plans are being developed to incorporate Geographical Information Systems into the program to effectively manage the water resources data and provide a land management perspective to the design of waterquality studies. Coordination with other agencies will be an important component of the program.

Issue analysis, regulatory liaison, and the translation and application of appropriate legal and technology-based solutions will provide opportunities for managing waterquality issues. The program includes applied research in water quality and the transfer of technical information. 


\title{
VARIATION IN CONCENTRATIONS OF ATRAZINE AND NITRATE IN GROUND WATER BENEATH AN IRRIGATED CORN FIELD NEAR SHELTON, NEBRASKA
}

\author{
A. Douglas Druliner*, \\ Abraham H. Chen, and Dwight Q. Tanner \\ U.S. Geological Survey \\ Water Resources Division \\ 406 Federal Building \\ Lincoln, Nebraska 68508
}

As part of the U.S. Geological Survey's Toxics Program, a study site was established near Shelton, Nebraska, to determine the seasonal variation in concentrations of atrazine and nitrate in ground water and to evaluate the effect of seasonal discharge from an onsite irrigation well on these concentrations. The study site is a 130-acre corn field with a centerpivot irrigation system. Two nests of three observation wells completed at different depths were installed approximately 100 feet and $\mathbf{4 0 0}$ feet south of the irrigation well.
Twelve ground-water samples were collected from the observation wells and six from the irrigation well from May through December during both 1987 and 1988. The ground-water samples were analyzed for dissolved oxygen, triazine herbicides, and nitrite plus nitrate. Nine groundwater samples were analyzed for two atrazine degradational products, de-ethylated and de-isopropylated atrazine.

Results of these analyses show that: (1) There is considerable seasonal variation in concentrations of atrazine and nitrate at a given site; (2) concentrations of atrazine increased with depth, whereas nitrate concentrations decreased with depth; (3) nitrate concentrations were significantly smaller (at the 95-percent confidence level) in wells 100 feet from the irrigation well than in wells of the same depth 400 feet from the irrigation well; (4) atrazine concentrations differed significantly (at the 95-percent confidence level) only in the shallow observation wells at the two nests; (5) de-ethylated atrazine was present at concentrations at least equal to that of atrazine in each of the observation wells.

*Presenting author.

\section{APPLICATION OF THE BATTERY OF TESTS APPROACH AND RANKING SCHEME TO ENVIRONMENTAL SAMPLES}

\author{
B. J. Dutka \\ Department of Environment \\ Rivers Research Branch \\ National Water Research Institute \\ Canada Centre of Inland Waters \\ Burlington, Ontario, Canada L7R 4A6
}

In 1985, a series of Canada-wide studies were initiated to evaluate a variety of biochemical microbiological and toxicological tests as potential candidates for the core group of a "battery of tests" approach to environmental studies. These core "battery of tests" data would permit us to make comparisons between sampling sites (water and/or sediment) thus providing managers with a means or scheme for establishing areas of concern or for evaluating the efficiency of remedial programs. In the presentation, the results of these studies will be described and three proposed core groups of tests for the "battery of tests" approach are described based on the type of sample or sediment extraction procedure used. Water concentration and sediment extraction procedure approaches and problems will also be discussed.
It was realized at the beginning of the study program that the provision of "battery of test" data in isolation would be insufficient information on which to compare Canada-wide samples and areas. To address this concern, a point ranking scheme was developed based on values observed in pure chemical studies and in a variety of samples. As new patterns of results were observed from our countrywide studies, modifications were 
made and incorporated into the point ranking scheme.

By applying the ranking scheme to the "battery of tests" collected data, the sites or samples with the greatest potential hazards or concerns can be prioritized. Thus, if 100 samples of water and sediment have been collected and tested, the top 3,5 or 20 samples with the greatest concerns, due to their implied contained hazards, can be derived for each type of sample, e.g., water, Milli $Q$ water extracted sediments and solvent extracted sediments.

\section{SIMULATION OF ATRAZINE MOVEMENT IN UNSATURATED MEDIA}

\author{
David A. V. Eckhardt \\ U.S. Geological Survey \\ Water Resources Division \\ 521 West Seneca Street \\ Ithaca, New York 14850
}

diffusion and dispersion, dissolution, adsorption, and loss by volatilization, hydrolysis, and biodecay. Mass flux of atrazine from the bottom of the profile was evaluated for 10 separate 720 -day . simulations. Two model variables (organic-carbon content and dispersivity) were varied in the simulations to evaluate the corresponding effect of each on mass flux.

Movement of atrazine through the soil profile is primarily by advection and is largely controlled by the amount of infiltration (difference between rainfall and evapotranspiration). High organic carbon content in upper zones of the profile retards atrazine movement owing to increased sorption, thus increasing atrazine travel time through the profile. Hydrolysis and biodecay subsequently decrease the mass of atrazine in the profile and hence further decrease the flux of atrazine in drainage. High dispersivity allows some atrazine to escape upper zones of high organic-carbon content before being sorbed, thereby resulting in increased mass flux. The mass flux is negligible in soils with the lowest dispersivity, primarily because retardation by sorption and subsequent hydrolysis and biodecay in organic-rich upper zones largely prevents atrazine movement under conditions of low dispersivity.

\section{ADSORPTION OF TRICHLOROETHYLENE TO MICROBIAL BIOMASS AND PEAT AT PICATINNY ARSENAL, NEW JERSEY}

\author{
Theodore A. Ehlke \\ U.S. Geological Survey \\ New Jersey District \\ 810 Bear Tavern Road, Suite 206 \\ Trenton, New Jersey 08628
}

Soil bacteria and peat may temporarily remove significant quantities of organic compounds in saturated and unsaturated portions of the aquifer at Picatinny Arsenal, New Jersey, by adsorption processes. Peat deposits, ranging in thickness from less than one meter to several meters, overlie a trichloroethylene (TCE) plume in the ground water.

Adsorption of TCE to microbial biomass and peat was studied using indigenous bacteria and peat from the site in static laboratory microcosms. Initially, to simulate a living system, ground water from the study area was given a spike of TCE, nutrients, and a bacteria inoculum. Microcosms were incubated at 20 degrees Celsius 
under aerobic conditions. After 12 days, the aqueous TCE concentration in nonsterile microcosms was 58 percent less than in similar sterile controls. The total TCE concentration (adsorbed and aqueous phases) did not change in sterile and nonsterile microcosms during the same period, indicating that essentially no biodegradation had occurred. Results suggest that TCE which was adsorbed by bacteria may be associated with the cell membrane, rather than cellular contents.

Adsorption of TCE to peat was studied in sterile laboratory microcosms by exposure of a TCE solution to peat at 23 degrees Celsius for 30 hours. The adsorption of TCE at an equilibrium concentration of 526 micrograms per liter was 0.121 milligram of TCE per gram of peat.
The isotherm was linear within a range of 3 micrograms per liter of TCE to 526 micrograms per liter.

Soil bacteria and peat probably are significant removal mechanisms for TCE in ground water at Picatinny Arsenal. The magnitude of the removal process involving peat likely is much greater than the adsorption to bacteria because of the large quantity of available peat.

\section{INTERMETALLIC CONTROLS ON MERCURY PARTITIONING IN BED SEDIMENTS OF NORTHERN WISCONSIN SEEPAGE LAKES}

\author{
John F. Elder \\ U.S. Geological Survey \\ Wisconsin District \\ 6417 Normandy Lane \\ Madison, Wisconsin 53719
}

water. One of the study lakes (Little Rock Lake) is artificially separated into two basins, one of which has been acidified, allowing comparison of ecosystem-level characteristics between an acidified basin and a reference basin.

Little Rock Lake contains only trace amounts of mercury; concentrations in the epilimnetic waters are commonly less than 1 nanogram per liter. In anoxic hypolimnetic waters, total mercury concentrations are approximately tenfold higher, and in the sediments, they generally fall in the range of 0.02 to 0.20 micrograms per gram. Up to 25 percent of sedimentary mercury may be sorbed to hydrous oxides of iron and manganese that are extractable with weak $(0.05 \mathrm{~N})$ hydrochloric acid. Lake acidification appears to have little effect on total mercury concentrations in bed sediments, but it may have appreciable effect on the proportion of particulate mercury that is extractable.

\section{SUGGESTIONS FOR A QUALITY ASSURANCE PROGRAM FOR EVALUATING LABORATORIES}

\author{
David E. Erdmann \\ U.S. Geological Survey \\ Water Resources Division \\ Branch of Quality Assurance \\ Box 25047, Mail Stop 401 \\ Lakewood, Colorado 80225
}

Water Resources Division (WRD) district offices of the U.S. Geological Survey estimate that in 1989 approximately 2.8 million dollars of analytical work will be performed for them by laboratories other than the U.S. Geological Survey National Water Quality
Laboratory. The evaluation and selection of competent laboratories is necessary to 
maintain the high standards of work done by the Survey.

The process of evaluating a laboratory should begin several months prior to the submission of samples for analysis and, for the WRD, consist of the following major steps:

1. Review the laboratory's quality assurance (QA) plan to ensure the lab has satisfactorily addressed the appropriate QA procedures.
2. Submission of reference samples, if possible, to evaluate laboratory's ability to perform the determinations of interest.

3. Completion of an onsite review to facilitate communications and verify instrumental and analytical compatibility.

4. During the period that samples are submitted to the laboratory, quality control samples are submitted, and analytical results reviewed, to ensure continued capability. These samples normally include reference materials, duplicates, matrix spikes, and blanks. Participation in the Branch of Quality Assurance's Standard Reference Water Sample program is a requirement.

This evaluation process should enable a district to select a laboratory that will meet the district's needs and assure that the analytical work meets the Survey's specifications.

\section{EFFECT OF OIL PRODUCTION ACTIVITIES ON SURFACE WATER QUALTTY IN THE KENTUCKY RIVER BASIN, KENTUCKY}

\author{
Ronald D. Evaldi* and James L. Smoot \\ U.S. Geological Survey \\ Kentucky District \\ 2301 Bradley Avenue \\ Louisville, Kentucky 40217
}

\author{
James A. Kipp \\ Kentucky Geological Survey \\ University of Kentucky \\ 228 Mining and Mineral Resources Building \\ Lexington, Kentucky 40506-0107
}

An investigation of selected streams draining oil-production fields was conducted as part of the Kentucky River basin National Water Quality Assessment pilot project. Objectives of the study were to determine water quality constituent concentrations and mass-transport estimates for these streams and to assess their impact on downstream water quality. Water-quality conditions were characterized by analyzing existing information, and by synoptic, periodic, and high-flow sampling over a two-year period at three fixed stations. Mass transport estimates were made using these observations and relations developed between certain target constituents and continuous specific-conductance monitoring and discharge records.

Constituent coverage included trace elements, major ions, and nutrients. The constituents of major interest were the ions and metals, such as bromide, chloride, and barium, commonly contamed in subsurface waters associated with oil reserves (brines). Concentrations of chloride, barium, and several other constituents were well in excess of applicable water-quality criteria. Although no water-quality criteria exist for bromide, its role in the formation of trihalomethane (THM) compounds made it a constituent of particular interest.

Mass transport estimates of bromide and chloride in the mainstem of the Kentucky River (downstream of the oil fields) related closely to oil-production estimates. Existing information and synoptic sampling data indicate that the principal source of bromide to surface waters in the Kentucky River basin is from brines associated with oil production.

*Presenting author. 


\title{
IMPACT OF AN ARTIFICIAL RECHARGE STRUCTURE ON PESTICIDE CONCENTRATIONS IN THE ADJACENT GROUND WATER
}

\author{
Mary E. Exner \\ Conservation and Survey Division \\ Institute of Agriculture and Natural Resources \\ University of Nebraska \\ 113 Nebraska Hall \\ 901 North 17th Street \\ Lincoln, Nebraska 68588-0517
}

Bromide homogeneously mixed in a 73-acre impoundment was used to trace the movement of recharge water to twenty-eight nested monitoring wells installed in ten clusters at four locations around the main pool. The 25 -square mile drainage area is planted largely to irrigated corn and grain sorghum. The data indicate there is a shallow groundwater flow system perched on a thin aquitard, which locally prevents most of the seepage from entering the regional aquifer. Of the twenty-seven pesticide residues measured, only atrazine was detected in 12 of 15 farmstead wells sampled in the baseline study of the regional aquifer. The concentrations averaged $0.04 \pm 0.05 \mathrm{ppb}$. Atrazine, alachlor, cyanazine, and metolachlor, however, were present in the recharge structure water and in adjacent monitoring wells screened in both groundwater flow systems. Atrazine concentrations ranged from 8.8 to $0.3 \mathrm{ppb}$ in the shallow flow system and from 2.5 to $0.1 \mathrm{ppb}$ in the wells in the regional aquifer that had bromide concentrations above background levels. Cyanazine, metolachlor, and alachlor concentrations were in the hundreds of parts per trillion in both flow systems. Unlike alachlor, metolachlor, which is more persistent, was present in the ground water at all three samplings during the 13-month period. Despite attenuation in the regional aquifer, the concentrations of all four herbicides were anomalously high in comparison to those in other ground water that has been monitored in Nebraska.

\section{APPLICATIONS OF INDUCTIVELY COUPLED PLASMA MASS SPECTROMETRY TO TRACE ELEMENT ANALYSIS OF NATURAL WATERS}

\author{
Lynda M. Faires \\ U.S. Geological Survey \\ National Water Quality Laboratory \\ 5293 Ward Road \\ Arvada, Colorado 80002
}

Inductively Coupled Plasma Mass Spectrometry (ICP-MS) is a powerful new instrumental technique for trace element analysis. Its outstanding features include multielement analysis capability, very low levels of detection, isotope ratio measurements, and speed of analysis. ICP-MS combines an argon plasma as the sample introduction system to generate vapor phase singly-charged ions of the elements from a sample solution and a unit-resolution quadrapole mass spectrometer as the detection system. The instrument can perform qualitative, semiquantitative, or quantitative analysis for most elements in the measure isotope ratios can be used for the determination of isotope abundances or the application of isotope dilution techniques to performs best with aqueous samples in which the analytes are in the parts per billion concentration range and the sample matrix does not exceed 0.1 percent total dissolved solids; therefore it is a logical technique for trace element analysis of natural waters. periodic table. The ability to quantitative analysis. ICP-MS
The advantages and limitations of the ICP-MS technique will be compared to the analytical methods currently used at the National Water Quality Laboratory. Examples of applications of ICPMS to trace element and isotopic analysis of natural waters will be presented. Possible interfaces with other analytical instrumentation such as liquid chromatography for sample cleanup and preconcentration will be described. Special considerations in the development of ICP-MS methods for routine analysis of natural waters will be discussed. 


\title{
EFFECTS OF INDUSTRIAL PUMPING AND RECHARGE ON ADVECTIVE TRANSPORT OF ORGANIC CONTAMINANTS, LONG ISLAND, N.Y.
}

\author{
Steven M. Feldman* and Douglas A. Smolensky \\ U.S. Geological Survey \\ Water Resources Division \\ 5 Aerial Way \\ Syosset, New York 11791
}

Ground-water contamination has resulted from use and disposal of synthetic organic contaminants in an industrial-zoned area in east-central Nassau County, Long Island, N.Y. The 11.4-square-mile area of investigation lies 1.5 miles south of the island's ground-water divide. A three-dimensional ground-water-flow model of the local area was constructed for finescale examination of the effect of human-induced stresses on local ground-water-flow patterns. The model was coupled with an islandwide ground-water-flow model to define the fluxes entering and leaving the boundaries of the study area.

Contaminants have moved from the water-table aquifer into the underlying Magothy aquifer, from which 14 industrial wells pumped a total of 8.05 million gallons per day in 1987. Most of the water is used for cooling purposes and is then returned to recharge basins. Cones of depression at pumped wells and water-table mounds beneath recharge basins have altered the natural ground-waterflow system by dramatically increasing the vertical component of flow beneath the industrial zone.
Trichloroethylene and tetrachloroethylene near the water table were measured at concentrations greater than 1,000 micrograms per liter and were detected at depths as great as 500 feet. The model predicts that, in areas where pumping and recharge occur, vertical hydraulic gradients increase threefold in response to the stresses. In addition, particletracking analyses based on flow-model results are compatible with field observations of the plume distribution.

*Presenting author.

\section{ADVANCES IN INSTRUMENTATION FOR AUTOMATICALLY MONITORING WATER QUALTYY}

\author{
James H. Ficken \\ U.S. Geological Survey \\ Hydrologic Instrumentation Facility \\ Building 2101 \\ Stennis Space Center, Mississippi 39529
}

Automatic monitoring of water quality is the use of streamside instruments to continuously measure, record, and transmit water-quality data. Water quality characteristics that are measured are water temperature, specific conductance, $\mathrm{pH}$, dissolved oxygen, and, sometimes, optical properties. Commonly, batterypowered systems with in situ sensors are employed. Less often, pumping systems are used to furnish water to off-stream sensors in flow-through chambers. Fouling of the sensors is a major problem and affects the accuracy of the data. U.S. Geological Survey personnel expend much time in field cleaning, calibrating, and maintaining waterquality monitoring systems. An Ohio study has shown that the fieldmaintenance time could be reduced by the use of "smart" sensor packages, which can be calibrated at the office and swapped out with sensors at the stream site.

Specifications for these "smart" sensor packages have been prepared and are being reviewed by vendors. The sensor systems will interface with the Survey's new Basic Data Recorder and communicate with it by digital transmission.
Improved sensors are needed to overcome the effects of fouling. New sensors are also needed to measure concentrations of nutrients, heavy metals, and a host of organic compounds that make up herbicides, pesticides, and other toxic and hazardous substances. In development are instruments that use techniques such as ionexchange chromatography, gas chromatography, mass spectroscopy, and fiber optics to make field measurements. Some have reached the point of operation in the field with skilled operators, but none are capable of unattended operation for any length of time. 


\section{GROUND-WATER FLOW TO SUBSURFACE AGRICULTURAL DRAINS IN THE WESTERN SAN JOAQUIN VALLEY, CALIFORNIA}

\author{
John Fio* and Steven J. Deverel \\ U.S. Geological Survey \\ 2800 Cottage Way \\ Sacramento, California 95825
}

\begin{abstract}
Field observations and numerical simulation of shallow groundwater flow in an artificially-drained agricultural field provide insights into the hydrologic and geochemical processes affecting the movement of saline water containing high concentrations of selenium to drain laterals in the western San Joaquin Valley, California. The drain laterals studied are located in about 9 meters of fine-textured soil overlaying a sand layer. A twodimensional, finite-difference simulation of steady-state flow to two drain laterals placed at 2 and 2.5 meters below land surface shows the influence of the sand
\end{abstract}

layer and irrigation on flow to the drains.

During unirrigated periods, shallow ground-water flow is predominantly affected by regional horizontal gradients, except near the deepest drain lateral. The traveltime to the deepest drain lateral from a location near the water table at a distance of $\mathbf{5 0}$ meters is about 20 years. About 80 percent of the drain water during unirrigated periods is attributed to vertical flow from the sand layer. In contrast, flow paths to each drain lateral during irrigation are deeper and concentric, and the traveltime to the deepest drain lateral from the same location is about 30 years. The proportion of water from the sand layer in the drain lateral during irrigation is about 60 percent.

Chemical and isotopic data from observation wells and drain laterals provide qualitative model verifications. The partially evaporated water high in selenium concentrations in the sand layer is enriched in oxygen-18 and deuterium. Water in the soil where the drain laterals are located is isotopically depleted and has a lower concentration of selenium. The isotopic and chemical composition measured in the drain water confirms the proportional mixture of the two water qualities that was predicted with the ground-water-flow simulation.

*Presenting author.

\section{EFFECT OF STORING DILUTE MERCURY SOLUTIONS IN POLYETHYLENE BOTTLES}

\author{
Marvin J. Fishman* \\ U.S. Geological Survey \\ National Water-Quality Laboratory \\ 5293 Ward Road \\ Arvada, Colorado 80002
}

\author{
David E. Erdmann and Jerry V. Farrar \\ U.S. Geological Survey \\ Branch of Quality Assurance \\ Box 25046, MS 401 \\ Denver, Colorado 80225
}

Since October 1984, the U.S. Geological Survey has used glass bottles and dichromate/nitric acid to store and preserve water sainples that are to be analyzed for mercury. Before October 1984, samples were collected in polyethylene bottles and preserved with nitric acid. The results of the analyses of these samples for mercury show a negative bias. It appears that mercury either adsorbed onto or diffused through the walls of the polyethylene bottles. To determine the apparent loss of mercury and the effect of storage in polyethylene bottles on natural samples, a number of reference sainples were transferred to polyethylene bottles, and one-half of the samples were treated with dichromate/nitric acid as a preservative. All of the standard reference samples were then analyzed for mercury periodically over two months. Data will be presented on the effect of storing mercury solutions in polyethylene bottles with and without the dichromate/nitric acid preservative.

-Presenting author. 


\title{
EFFECT OF SAMPLE HANDLING ON OBSERVED MERCURY CONCENTRATIONS IN USGS NATIONAL NETWORK SURFACE-WATER SAMPLES, 1973-88
}

\author{
Kathleen K. Fitzgerald \\ U.S. Geological Survey \\ Wisconsin District \\ 6417 Normandy Lane \\ Madison, Wisconsin 53719
}

Mercury concentrations in samples collected for the National Stream Quality Accounting Network (NASQAN) and the Hydrologic Benchmark Network (HBN) have varied widely during 1973-88. During this period, methods for preservation of mercury samples have changed, mercuric chloride has been introduced as a preservative for nutrient samples, and the minimum reporting level for mercury analyses has decreased from 0.5 to 0.1 micrograms per liter. In addition, methods for collecting and handling water-quality samples have changed over the years. Some of the variation in reported mercury concentrations can be attributed to the changes in sample collection and preservation techniques. Commonly, measured concentrations are anomalously high, suggesting, in many cases, that contamination has occurred. Very high concentrations were documented prior to 1985 when polyethylene bottles, which allow rapid loss of mercury from a water sample by vapor migration, were in use. Prior to 1981, broken thermometers and elemental mercury carried in vehicles for use in manometers were the likely primary sources of contamination. In 1981, mercuric chloride used to preserve nutrient samples became another potential source. The anomalously high mercury concentrations caused by sample contamination and the general reduction in mercury concentrations following the changes in sample handling and data reporting through the years are evident in the National Network data bases.

\section{SUPERCRITICAL FLUID EXTRACTION OF TRACE ORGANIC AQUATIC POLLUTANTS PRECONCENTRATED ON SOLID SORBENTS}

\author{
William T. Foreman \\ U.S. Geological Survey \\ National Water Quality Laboratory \\ Methods Research and Technology Transfer Program \\ 5293 Ward Road \\ Arvada, Colorado 80002
}

Conventional liquid-liquid extraction techniques for isolating trace organic pollutants from water are time consuming and require extensive manual manipulations that may cause contamination and result in poor recovery. An alternative extraction technique uses solid sorbent technology for preconcentrating water contaminants, preferably in the field. The most common method for eluting analytes from solid sorbents is desorption with organic solvents. This process has the disadvantage of requiring variable solvent volumes and manual solvent reduction prior to analysis. Another approach uses thermal desorption of analytes directly into a gas chromatograph (GC), but requires that both analytes and sorbent be thermally stable and is limited to low molecular weight compounds. A relatively new approach to solid sorbent desorption uses supercritical fluids, which have near-liquid-like densities, but faster mass transport properties than liquid solvents. Supercritical fluid extraction (SFE) techniques have demonstrated the potential for fast quantitative desorption, selective sequential desorption using varied fluid densities and types, rapid quantitative extract concentration, and the possibility of directly coupling the desorption step with GC analysis. This paper presents our efforts towards developing and evaluating SFE methods for the desorption of pesticides and other trace organic aquatic pollutants preconcentrated on sorbent cartridges. Results from spike recovery experiments and real surface- and ground-water applications utilizing solid sorbent field sampling and SFE procedures will be presented. 


\author{
Steven A. Frenzel \\ U.S. Geological Survey \\ Water Resources Division \\ 230 Collins Road \\ Boise, Idaho 83702
}

done by the U.S. Geological Survey during low-flow conditions; data were collected from October to December 1987 and from January to March 1988.

Trace-element concentrations in the Boise River were less than or near analytical detection levels. All detectable concentrations were less than chronic toxicity criteria. Benthic invertebrate communities were sampled using artificial substrates at sites upstream and downstream from each wastewater treatment facility. Invertebrate communities at all sites were dominated by midges, black flies, Baetidae mayflies, and Hydropsychidae caddisflies. Relative abundances of all insect families collected were compared using a nonparametric test for association, which indicated that effluents had little effect on community structure. A test which discriminates between sites receiving enriching and stressinducing effluents, the coefficient of community loss, indicated benign enrichimg effects on insect communities from the effluents. Distributions of trace-elementintolerant mayflies were compared using a nonparametric analysis of variance, which indicated that intolerant organisms were not adversely affected by effluents.

\section{GEOGRAPHICAL DISTRIBUTIONS OF TRACE ELEMENTS IN BOTTOM MATERIAL AND SUSPENDED SEDIMENT IN THE YAKIMA RIVER BASIN, IN CENTRAL WASHINGTON}

\author{
Gregory J. Fuhrer*, Stuart W. McKenzie, \\ and Joseph F. Rinella \\ U.S. Geological Survey \\ Pacific Northwest District \\ National Water Quality Assessment Program \\ 10615 S.E. Cherry Blossom Drive \\ Portland, Oregon 97216
}

\author{
Richard F. Sanzolone \\ U.S. Geological Survey \\ Branch of Geochemistry \\ Denver Federal Center, MS 973 \\ PO BOX 95046 \\ Denver, Colorado 80225
}

The Yakima River Basin is one of four surface-water pilot studies in the U.S. Geological Survey's National Water Quality Assessment Program. Program objectives include identifying temporal and spatial variations of trace-element concentrations in suspended sediment and determining sources of trace elements in fluvial sediments.
To determine trace-element associations with fluvial sediment, about 330 bottom-material samples were collected from headwater sites, 90 bottom-material samples were collected from tributaries and main-stem sites, and 180 suspended-trace-element samples are being collected from monthly samplings at seven fixed stations over a three-year period. Tributary sites were selected to determine the significance of trace-element transport from headwater sites and to evaluate anthropogenic effects. Bottom materials--less than 0.062 millimeters in diameter--and suspended-sediment samples, were totally digested and analyzed for 43-trace elements.

Bottom materials from headwater sites, located in the High Cascades which includes andesitic and rhyolitic volcanics and granitic- and ultramafic-intrusive units, are enriched in arsenic, 
cobalt, chromium, copper, mercury, nickel, and zinc. Copper, mercury, and nickel are transported downstream to the main stem and throughout the irrigation distribution system.
Samples from fixed stations, downstream of headwaterenriched sites, also contain enriched suspended-copper and nickel concentrations. Conversely, samples from headwater sites lack enriched lead concentrations; however, concentrations of suspended- and bottom-material lead at urban sites are enriched relative to headwater sites.

${ }^{*}$ Presenting author.

\section{SPECIATION OF SOLUBLE AND ADSORBED SELENIUM IN SOILS, WESTERN SAN JOAQUIN VALLEY, CALIFORNIA}

\author{
Roger Fujii \\ U.S. Geological Survey \\ California District Office \\ 2800 Cottage Way \\ Sacramento, California 95825
}

lysimeters, and hydraulically extracted soil pore water showed that selenate is the predominant form of soluble selenium in all but the most leached soils. Nearsurface soils subjected to considerable leaching had much lower concentrations of soluble selenium, a substantial proportion of which was selenite. Phosphate-extractable selenium was mostly com- posed of selenite and compared well with isotopically exchangeable selenite, indicating that the phosphate extract can provide an estimate of adsorbed selenite. These results indicate that mobile selenate is readily leached from these soils, and other less soluble forms such as adsorbed selenite may be slowly released over time.

\section{THE BACTERIOLOGICAL QUALITY OF STREAMS IN TROPICAL ISLANDS}

\author{
Roger S. Fujioka* \\ Water Resources Research Center \\ University of Hawaii \\ Honolulu, Hawaii 96822
}

\author{
Johnson Yee \\ U.S. Geological Survey \\ Water Resources Division \\ 677 Ala Moana Blvd., Suite 415 \\ Honolulu, Hawaii 96813
}

Streams on tropical islands commonly are used for recreation and are monitored for fecal indicator bacteria (fecal coliform, fecal streptococci) to assess their sanitary quality. Streams classified for recreational use in Hawaii (Chapter 11-54, Hawaii Water Quality Standards, 1988) should not exceed a geometric mean of 200 fecal coliform per 100 milliliters. These water quality standards assume that the sources of these fecal indicator bacteria are primarily from sewage or direct fecal contamination of the streams.
Most streams on the island of Oahu, Hawaii, consistently contain high concentrations of fecal coliform, usually exceeding the recreational water quality standards. More recent evidence indicates that these streams will not meet the new EPA standards of 33 enterococci per 100 milliliters or 126 Escherichia coli per 100 milliliters. These streams do not receive sewage or other point sources of discharges and contain high concentrations of fecal streptococci, suggesting a nonhuman source of fecal contamination. However, the presence of these indicator bacteria in soil suggest that these bacteria may be multiplying in the environment and are being washed into the streams by rain. An examination of the data collected by the U.S. Geological Survey for several streams on several islands in the State of Hawaii supports the theory that high concentrations of indicator bacteria can be expected in streams in the absence of known sources of fecal contamination. This information may indicate that a re-evaluation of the means to assess the sanitary quality of streams in tropical islands is needed.

*Presenting author. 


\section{NONPOINT SOURCE CONTAMINATION OF GROUND WATER IN CENTRAL FLORIDA FROM URBAN RUNOFF, CITRUS CULTIVATION, AND PHOSPHATE MINING}

\author{
Edward R. German \\ U.S. Geological Survey \\ $224 \mathrm{~W}$. Center Street \\ Altamonte Springs, Florida 32714
}

Three specific land uses were studied to determine their effects on ground-water quality. Groundwater samples were collected in an urban area, a citrus growing area, and a phosphate mining area. The chemical analyses of these samples were compared to those of ground water from a forested area having similar hydrology. The study is part of the Toxic Waste--Ground Water Contamination Program of the U.S. Geological Survey.

In the urbanized area in Orlando, Florida, drainage wells are used to inject, by gravity, surface runoff into the Upper Floridan aquifer. This has resulted in a tenfold increase in ammonia and a threefold increase in total organic carbon in water within the Upper Floridan aquifer in areas where the density of drainage wells is high, as compared with the forested area. Results of rank correlation analysis infer that ammonia concentration is directly related to drainage-well density.

Citrus cultivation has resulted in an eightfold increase in median specific conductance and a threehundredfold increase in median nitrate concentrations in the underlying surficial aquifer system, based on a comparison of water quality in cultivated and forested areas. The herbicide bromacil has reached the water table at most of the sampling sites; concentrations are highest where the water table is closest to the land surface.

Activities associated with phosphate mining and ore processing have resulted in a nearly tenfold increase in median specific conductance and a thirtyfold increase in median ammonia concentrations in the surficial aquifer system, based on a comparison of water quality in mining and forested areas. Four wells in reclaimed phosphate mining areas contained more than 50 organic compounds.

\section{UNCERTAINTY OF REGRESSION-BASED CONSTITUENT TRANSPORT ESTIMATES}

\author{
Edward J. Gilroy* and Timothy A. Cohn \\ U.S. Geological Survey \\ Branch of Systems Analysis \\ National Center, MS 410 \\ Reston, Virginia, 22092
}

\author{
Robert M. Hirsch \\ U.S. Geological Survey \\ Office of Research and External Coordination \\ National Center, MS 436 \\ Reston, Virginia 22092
}

Estimates of long-term transport (load) of constituents at periodic record stations are commonly obtained by summing retransformed estimates from regressions of logarithıns of load or concentration. Typical explanatory variables for these regressions include functions of: flow, change in flow, time relative to some origin, and season of year. These estimates are rarely corrected for inherent transformation bias, and thus have underestimated constituent loads since their introduction by Miller (1951). Three alternate estimators which do correct for transformation bias are described. An appropriate measure of uncertainty (error) for these four estimators of long-term transport has been unavailable in the water-resources literature. Here we present the errors of longterm transport at periodically measured stations as functions of the observed values of the explanatory variables from the long-term record and summary statistics of the regression data. Such estimates of error can be used (1) in designing sampling strategies to minimize the uncertainty in estimates of long-term transport subject to a constraint on the number of samples to be taken and (2) in assessments of the confidence that can be placed in estimates of constituent transport. Errors are increased when a biased method (the retransformed rating curve) is used, and when data used to calibrate the regression model differ from the data to be estimated. Applications of these error functions are illustrated.

*Presenting author. 


\title{
DATA MANAGEMENT, CLEANUP, AND ANALYSIS FOR FLORIDA'S AMBIENT BACKGROUND GROUND WATER MONITORING NETWORK
}

\author{
Tim Glover \\ Bureau of Ground Water Protection \\ Florida Department of Environmental Regulation \\ 2600 Blair Stone Road \\ Tallahassee, Florida 32399-2400
}

Florida's Ambient Background Ground Water Monitoring Network consists of approximately 1,700 wells and has been developed through the actions of the Florida Department of Environmental Regulation, the five Water Management Districts, and certain counties. There are now over 125,000 records of analytical data collected on these wells. Because of various computer capabilities among the principal parties, microcomputers are being used for data management and transfer. A DER developed data base management system is used to store and retrieve these data.

Because of the large quantity of data, their various reporting formats, and the need for high quality data, extensive data verification, correction, and outlier determination has been necessary. Various goodness checks, graphical and statistical outlier determinations, and missing data/bad code checks have been developed and run.

By Legislative mandate, the network is to be used for the definition of background ground water quality, identification of temporal changes in the ground water quality, and to identify the effects of man's use of the land on ground water quality. The first step in meeting these goals is the definition of areas of consistent water quality. Factor and cluster analysis are being tried to meet this first step. The next step is the estimation of concentrations in nearby wells in the same aquifer. Kriging is being investigated for the development of these predictive surfaces.

\section{SOLID- AND SOLUTE-PHASE TRANSPORT OF ARSENIC IN WHITEWOOD CREEK, SOUTH DAKOTA}

\author{
Kimball E. Goddard* and William R. Roddy \\ U.S. Geological Survey \\ Rapid City Subdistrict Office \\ 515 Ninth Street, $\mathrm{Rm} 237$ \\ Rapid City, South Dakota 57701
}

From 1876 to 1977 , about 10 million metric tons of finely ground mill tailings containing arsenopyrite were discharged to Whitewood Creek near Lead and Deadwood, South Dakota. The result is an estimated 1.9 million kilograms of arsenic stored in fluvial sediments in and along Whitewood Creek downstream from Lead. This arsenic mass is being exported from the basin by solid- and solute-phase transport in Whitewood Creek.
The total arsenic mass-flux was estimated to be about $5,900 \mathrm{~kg} / \mathrm{yr}$ (kilograms per year) at the streamflow-gaging station Whitewood Creek above Vale. The solid-phase arsenic flux, about $4,800 \mathrm{~kg} / \mathrm{yr}$, was estimated using a sediment-transport curve, flow duration statistics, and the mean concentration of arsenic in suspended sediment. The solutephase arsenic flux, about 1,100 $\mathrm{kg} / \mathrm{yr}$, was estimated by applying discharge-concentration regres- sions and time-concentration relations to daily mean discharges. At the current rate of transport, it would take about 320 years to remove the stored arsenic mass from the Whitewood Creek basin. However, some arsenic-bearing sediments are in deposits 3 to 5 meters above, and several hundred meters distant from, the active channel and are not readily available for transport.

-Presenting author. 
A RECONNAISSANCE FOR TRIAZINE HERBICIDES IN SURFACE WATERS OF THE UPPER MIDWESTERN UNITED STATES

\author{
Donald A. Goolsby* \\ U.S. Geological Survey \\ Water Resources Division \\ Box 25046, MS 406 \\ Denver Federal Center \\ Denver, Colorado 80225
}

\author{
E. Michael Thurman \\ U.S. Geological Survey \\ Water Resources Division \\ 4821 Quail Crest Place \\ Lawrence, Kansas 66049
}

\author{
Dana W. Kolpin and Mark G. Detroy \\ U.S. Geological Survey \\ Water Resources Division \\ PO Box 1230, Room 269, Federal Bldg. \\ 400 South Clinton Street \\ Iowa City, Iowa 52244-1230
}

In 1989 , a reconnaissance study was initiated to determine the distribution, and concentrations of triazine herbicides in surface waters in the corn producing region of the upper midwestern United States. The study area includes all or parts of 11 States in the Ohio, Upper Mississippi, and Lower Missouri River basins. Cropland in the study area produces more than 75 percent of the Nation's corn and more than 60 percent of the Nation's soybeans. About 60 percent of the pesticides and about 50 percent of the fertilizer used in the United States are applied to the cropland in this region. A large percentage of the pesticides consists of triazine herbicides, principally atrazine. The effects of the intensive application of the triazine herbicides on surface waters in the region are largely unknown.

Two specific objectives of the study are to: (1) Determine the geographic and seasonal distribution of triazine herbicides in streams, and (2) determine the usefulness and limitations of a low-cost, enzyme-based immunoassay analysis for determining triazine-herbicide concentrations on a regional-scale. The approach consisted of allocating 150 sampling sites among the 11 States in the study area based on the quantity of corn produced. Within each State, the sampling sites were selected from existing U.S. Geological Survey stream-gaging stations by a process that assured an adequate geographic distribution. Each site was sampled three times: (1) Before application of triazine herbicides (March-April), (2) during the first storm runoff following application of triazineherbicides (May-June), and (3) during late fall (OctoberNovember). All samples were analyzed for triazine herbicides using an immunoassay analysis and for nitrate-nitrogen concentrations. In addition, one-third of the samples were analyzed by gas chromatography/mass spectrometry (GC/MS) for 11 herbicides and some of their metabolites.

Sample collection began in March 1989. Immunoassay results indicate that triazine herbicide concentrations in streams prior to herbicide application exceeded the detection limit of 0.2 micrograms per liter at 41 percent of the sites. The most frequent detections were in Iowa, Illinois, and Ohio. GC/MS results indicate that atrazine and its metabolites are the most frequently detected herbicides. Results from quality assurance samples indicate that immunoassay and GC/MS analyses agree within about 20 percent. This presentation will include a discussion of results of the GC/MS and immunoassay analyses, seasonal and geographic distribution of triazine herbicide concentrations, occurrence and seasonality of atrazine metabolites, a comparison of immunoassay and GC/MS analyses, and the relation (if any) between nitrate and triazine herbicide concentrations.

*Presenting author. 


\title{
QUALITY OF WATER AND BOTTOM SEDIMENTS ASSOCIATED WTTH IRRIGATION DRAINAGE FROM THE ANGOSTURA RECLAMATION UNIT, SOUTHWESTERN SOUTH DAKOTA
}

\author{
Earl A. Greene \\ U.S. Geological Survey \\ Water Resources Division \\ Rm. 237, 515 9th Street \\ Rapid City, South Dakota 57701
}

Water and bottom sediment samples were collected during 1988 throughout the Angostura Reclamation Unit (a U.S. Bureau of Reclamation irrigation project) and adjacent areas in the Cheyenne River basin in southwestern South Dakota. Samples were collected three times during and one time following the irrigation season at one reservoir, three irrigation return-flow sites, and five sites unaffected by irrigation returnflow. Concentrations of major ions, selected trace elements, and pesticide residues in water and bottom sediments were determined. The analytical results were compared to U.S. Environmental Protection Agency (EPA) drinking-water standards and national baseline values (Smith, R.A., Alexander, R.B., and Wolman, M.G., 1987, Waterquality trends in the nation's rivers: Science, v. 235, p. 1607-1615).

Concentrations of major ions in water samples generally exceeded the national baseline values. Except for selenium, which equaled or exceeded the national baseline value at all sites, other trace-element concentrations in water generally were less than baseline values and generally did not indicate any potential toxicity problems. Pesticide residues at all water sampling sites were less than the analytical detection limits.

Trace-element concentrations in bottom sediments generally were similar to baseline values in area soils. The maximum concentrations of selenium $(14 \mu \mathrm{g} / \mathrm{g}$ (micrograms per gram)), strontium (740 $\mu \mathrm{g} / \mathrm{g})$, vanadium $(200 \mu \mathrm{g} / \mathrm{g})$, and zinc $(140 \mu \mathrm{g} / \mathrm{g})$ were substantially greater than the 95-percent expected baseline range for bottom sediments. Pesticide residues in bottom sediments were less than the analytical detection limits at all sites.

\section{EPA'S WATER QUALITY ASSESSMENT PROCESS}

\author{
Geoffrey H. Grubbs \\ Assessment and Watershed Protection Division \\ U.S. Environmental Protection Agency \\ Washington, DC 20460
}

EPA works closely with the States to monitor and assess the quality of the Nation's surface waters. The primary objectives of EPA and State monitoring programs are to identify problem waterbodies, determine the water quality status of waterbodies compared to Federally-approved State water quality standards, and support regulatory activities. Monitoring is conducted by the States using Federal grants, and assessment results are reported to EPA under the authority of various sections of the Clean Water Act (CWA). EPA also conducts special studies addressing issues of national concern, such as the bioaccumulation of toxic substances.

State reports submitted biennially to EPA under Section 305(b) of the CWA are the primary mechanism used for reporting water quality assessment results. EPA issues guidelines for the States to report on the extent to which waters meet State standards and the goals of the Clean Water Act, the causes and sources of impairment, the impacts of pollution (such as fishing restrictions), the effectiveness of pollution control actions, and related issued.

The Section 305(b) process is continuously evolving. As part of its effort to improve the quality and usefulness of reported information, EPA is engaged in efforts to reduce inconsistencies in State assessment and reporting methods; develop new data management capabilities; incorporate more representative measures of ecological integrity; and explore improved methods of trend assessment. 


\author{
Geoffrey H. Grubbs \\ Assessment and Watershed Protection Division \\ U.S. Environmental Protection Agency \\ Washington, DC 20460
}

The objective of the U.S. Environmental Protection Agency's Nonpoint Source Program is to achieve measurable environmental results through timely and effective implementation of strong State nonpoint source (NPS) management programs. To accomplish this objective, EPA is moving aggressively on three fronts.

First, EPA is working actively with a broad range of interested parties to establish a strong, viable national framework for the program. EPA Headquarters and Regional Offices are assisting States to update their NPS assessment reports and management programs and to begin implementation of approved management programs. The Agency is providing technology transfer through national and regional conferences, regional workshops, and a national clearinghouse. EPA is working with selected Federal agencies to increase their support for State NPS efforts and with other EPA programs such as ground water, wetlands, estuaries and stormwater permits to ensure appropriate linkages with the NPS program. Finally, EPA is providing training and assistance to the States and localities in building public support for NPS implementation.

Second, EPA is taking a variety of actions to encourage full use of available resources. NPS staff are working closely with other Agency offices and the States to make funds under Titles I, II and VI of the Clean Water Act (CWA) available to States and are assisting selected States and localities to develop their own innovative funding mechamisms. In addition, EPA is working with other Federal agencies to facilitate broader use of their resources to support State and local NPS management activities.

Third, EPA is orienting the NPS Program to show progress in achieving environmental results. The 1990 Report to Congress on progress under Section 319 of the CWA will provide a frank evaluation of progress to date and contain recommendations for changes needed to ensure measurable environmental results. EPA is aggressively pursuing development and use of methods for measuring the effectiveness of best management practices and for improving monitoring programs to show results.

\title{
ECOLOGICAL ASPECTS OF THE NATIONAL WATER-QUALITY ASSESSMENT PROGRAM
}

\author{
Martin E. Gurtz \\ U.S. Geological Survey \\ Post Office Box 2857 \\ Raleigh, North Carolina 27602
}

Examination of aquatic communities and their associated habitats as part of a water-quality assessment provides a level of interpretation that integrates physical, chemical, and biological water-quality parameters. The U.S. Geological Survey is presently developing plans for conducting ecological surveys as part of the National Water-Quality Assessment Program (NAWQA).
Ecological surveys will be conducted in two stages in each NAWQA basin, at sites ranging from mainstem stations to loworder tributaries, including reference sites having minimal human influences. Stage $I$ is a reconnaissance-type synoptic survey of approximately 30 to 50 sites conducted once at the beginning of the 3-year NAWQA study, with the emphasis on qualitative sampling of invertebrate communities. The purposes of Stage I are to obtain a broad spatial description of biological communities and habitat characteristics throughout the basin and to evaluate and compare candidate sites for Stage II sampling.

Stage II is designed as a repeated synoptic survey (4 times during a 3-year NAWQA study) and will involve more intensive sampling of biological communities (fish, invertebrates, and algae) at fewer sites (15 to 20). Ecological surveys will 
be coordinated with other biological activities, such as sampling of biological tissues, as well as with activities of other resource agencies and researchers. The approach and methods for an ecological survey are being tested in two pilot study basins: the
Yakima River in Washington and the upper Illinois River in Illinois, Indiana, and Wisconsin.

\title{
EFFECTS OF EXTRACTION PROCEDURES ON ANALYSIS OF WATER FROM CONFINING UNITS IN THE NEW JERSEY COASTAL PLAIN
}

\author{
Mark A. Hardy* and Amleto A. Pucci, Jr. \\ U.S. Geological Survey \\ New Jersey District \\ 810 Bear Tavern Road \\ West Trenton, New Jersey 08628
}

As part of an investigation of borehole core materials in Howell Township, New Jersey, water samples extracted from Coastal Plain confining units were chemically analyzed. The major anticipated limitations on quality of the data produced were the small volumes of samples and the effects of extraction pressures on water chemistry. Therefore, additional water samples were analyzed for the purpose of quality-assurance to help evaluate the effects of these limitations.

Water-sample volumes for analysis of major ions, $\mathrm{pH}$, specific conductance, and alkalinity generally were less than 15 milliliters. Analytical results for selected duplicate samples were typically within predetermined precision criteria and in no case varied sufficiently to impair data interpretation. Analysis of deionized water that had passed through the extraction equipment indicated that, except for pressure effects, the equipment did not affect the water samples significantly.

Three water samples were extracted from one core at pressures of $900,2,300$, and 4,100 pounds per square inch. Increasing extraction pressures primarily affected concentrations of bicarbonate (250-percent increase), silica (36-percent increase), potassium (22-percent decrease), and hydrogen ion (97percent decrease). Although these concentration changes did not significantly change the proportions of major ions in these samples having high dissolvedsolids concentrations $(1,700$ milligrams per liter), such changes might in samples having lower dissolved-solids concentrations.

Evaluation of the qualityassurance samples confirmed previously observed differences between confining-unit and aquifer water chemistries. Causes of the unique water chemistries in the confining units, and their possible effects on the chemical evolution of water in aquifers are currently being investigated.

*Presenting author.

\section{PARTITIONING OF ELEMENTS BETWEEN TWO SIZE FRACTIONS IN SEDIMENT SAMPLES FROM THE WESTERN UNITED STATES}

\author{
Thelma F. Harms*, R. C. Severson, and K. C. Stewart \\ U.S. Geological Survey \\ Denver Federal Center \\ Box 25046, Mail Stop 973 \\ Denver, Colorado 80225
}

The Department of Interior task group on irrigation drainage conducted field-screening studies at Bureau of Reclamation irrigation projects associated with wildlife refuges in the western United States to evaluate potential adverse effects of irrigation practices on fish and wildlife, or other water users. Nine areas were included in the field-screening studies in 1986-1987 and an additional eleven areas included in 1987-1988. At the 20 areas, a total of about 200 samples of bottom material from streams, rivers, marshes, ponds, lakes, and drainage ditches were collected. The bottom materials were sieved into less than 2 millimeter (less than 0.063 millimeter material included) 
and less than 0.063 millimeter fractions and analyzed for their total content for major and minor elements, including heavy metals, arsenic, selenium, and water- soluble boron. Comparisons are made between the fractions to show enrichment or depletion of various elements. The results are useful in designing sampling plans for bottom materials where specific elements are of primary interest.

*Presenting author.

WATER-QUALITY TRENDS OF THE ALBEMARLE-PAMLICO ESTUARINE SYSTEM, NORTH CAROLINA

\author{
Douglas A. Harned* and Marjorie S. Davenport \\ U.S. Geological Survey, WRD \\ Post Office Box 2857 \\ Raleigh, North Carolina 27602
}

The U.S. Geological Survey compiled and analyzed existing hydrologic and water-quality data from more than 200 stream and estuary stations, including seven stations of the National Stream Quality Accounting Network, in the Albemarle-Pamlico estuarine system (APES) to identify longterm temporal and spatial trends. The APES study area, which has a total basin area of 31,000 square miles, is currently the subject of a comprehensive research effort by State, Federal, university, and local interests. Regression-residuals analysis, seasonal Kendall's Tau test for trends, and graphical analysis using annual box plots were employed to determine trends.

Profound change has occurred in the water quality of the APES area over the last 30 years. Analysis of water-quality data upstream from the estuaries indicates increases in discharge-adjusted values of specific conductance and alkalinity and hardness, and in concentrations of phosphorus, chloride, and dissolved solids. In the estuaries, $\mathrm{pH}$ is increasing, except in the Pamlico River where it is decreasing. Generally, there is a decrease in suspended inorganic material in the system. Salinities are decreasing for sections of the Pamlico River and increasing for parts of Albemarle Sound. Nitrogen concentrations are decreasing, except in the Pamlico River where they are increasing. Phosphorus concentrations are increasing in the Pamlico River and decreasing elsewhere. Annual average data show that nitrogen is the limiting nutrient in the Neuse and Pamlico Rivers. Phosphorus is limiting in the rest of the area. Chlorophyll-a levels are increasing in parts of the Neuse and Pamlico Rivers and decreasing in parts of the Chowan River.

\title{
TRANSPORT OF BACTERIA THROUGH CONTAMINATED AQUIFER SEDIMENTS IN SMALL-SCALE TRACER EXPERIMENTS: THE ROLE OF SORPTIVE FILTRATION
}

\author{
Ronald W. Harvey* \\ U.S. Geological Survey \\ Water Resources Division \\ 345 Middlefield Rd., MS 465 \\ Menlo Park, California 94025
}

\author{
Stephen P. Garabedian \\ U.S. Geological Survey \\ Water Resources Division \\ New England District \\ 28 Lord Road, Ste. 280 \\ Marlborough, Massachusetts 01752
}

A sorptive-filtration model that is used to describe removal of colloidal particles during packed bed filtration in water treatment applications was modified and evaluated for describing transport of bacterial populations through contaminated, sandy aquifer sediments. The filtration model was applied to the transport of indigenous bacteria in a small-scale (7 meter), natural-gradient tracer test and in the upgradient portion of a 4 kilometer-long plume of organically-contaminated ground water. The model, which was corrected for retardation of a part of the population and for dispersion, accurately accounted for much of the observed breakthrough for stained bacteria in the small-scale tracer experiment. In addition, the model accounted for the observed 54 
percent increase in average cell size for a bacterial population being transported downgradient along a 640-meter section of the contaminant plume. However, several uncertainties were apparent in the application of the colloid-filtration theory. Also, the effects of aquifer heterogeneity, bacterial growth, grazing by protozoa, lysis, and secondary pore structure (preferred flow paths) would necessitate the use of a more complex model for large-scale transport experiments with bacteria. However, our small-scale test results suggest that filtration theory may be useful as one component in a multi-component description of immobilization in transport models involving bacteria in ground water.

-Presenting author.

\title{
SUPERCRITICAL FLUID EXTRACTION (SFE) AND COUPLED SFE-GC ANALYSIS OF ENVIRONMENTAL SOLIDS AND SORBENT RESINS
}

\author{
Steven B. Hawthorne* and David J. Miller \\ University of North Dakota \\ Energy and Minerals Research Center \\ Campus Box 8213 \\ Grand Forks, North Dakota 58202
}

The extraction and concentration of organic pollutants from environmental solids and sorbent resins is often the slowest and most error-prone step of an entire analytical scheme. Liquid solvent extractions take several hours to perform, and result in a diluted sample that often must be concentrated prior to analysis. In contrast, supercritical fluid extraction (SFE) can yield quantitative recovery of organic pollutants from environmental solids and sorbent resins in a few minutes. SFE is simple and inexpensive to perform, and generates no liquid solvent waste.
Since many supercritical fluids are gases at room temperature, analyte concentration steps are simplified, and the SFE step can be directly coupled with capillary gas chromatography (SFE-GC). SFE-GC yields maximum sensitivity since all of the extracted analytes are quantitatively transferred into the capillary GC column for cryogenic trapping prior to conventional GC analysis using MS, FID, or ECD detectors. With SFE-GC, quantitative analysis of environmental solids completed in less than one hour, and ppb detection limits can be attained with samples as small as
$1 \mathrm{mg}$ using a conventional GC/MS Excellent quantitative agreement with National Institute of Standards and Technology (NIST) certified standards has been achieved. The use of SFE and coupled SFE-GC for the rapid and quantitative extraction and analysis of PCBs, PAHs, heteroatomcontaining PAHs, pesticides, and fuel components from a variety of matrices including soils and sediments (including the new standard sediment from NIST), and Tenax and polyurethane foam (PUF) sorbent resins will be described.

*Presenting author.

\section{STATISTICAL ANALYSIS OF DATA BELOW DETECTION LIMIT(S)}

\author{
Dennis R. Helsel* and Timothy A. Cohn \\ U.S. Geological Survey \\ Water Resources Division \\ Branch of Systems Analysis \\ 410 National Center \\ Reston, Virginia 22092
}

\begin{abstract}
Water-quality data may contain values known only to be below one or more limits of detection. Such values are commonly referred to as "less-thans." Traditional methods of statistical analysis, such as computation of means, or parametric
\end{abstract}

tests such as the t-test, cannot effectively incorporate "less-thans." However, statistical meehods that are less familiar to hydrologists are available for analysis of such data. These methods are surveyed here.
First, methods for estimation of summary statistics (mean, standard deviation, median and interquartile range) for data sets including "less-thans" will be presented. These methods have been shown to be robust (generally applicable) 
over a wide range of data distributions. The limitations of these methods will also be discussed in the context of publishing summary statistics in a U.S. Geological Survey report.

Second, tests for differences between data sets which include "less-thans" will be illustrated. Nonparametric tests can easily incorporate data with one detection limit. Tests appropriate when more than one detection limit occur are more problematic. The implications for changing detection limits over time, and with differing detection limits based on sample characteristics, will be discussed.
Third, methods for regression with data which include "lessthans" are discussed. Two techmiques--logistic regression and tobit analysis--have great utility for data collected by Survey scientists. These techniques are just beginning to be applied in Survey reports, and examples of their use will be given.

* Presenting author.

\section{VARIABILITY IN THE CONCENTRATION OF VOLATILE ORGANIC COMPOUNDS DURING WELL PURGING}

\author{
Beverly H. Herzog* \\ Illinois State Geological Survey \\ 615 East Peabody Drive \\ Champaign, Illinois 61820
}

\author{
Jacob Gibs and Thomas E. Imbrigiotta \\ U.S. Geological Survey \\ 810 Bear Tavern Road \\ West Trenton, New Jersey 08628
}

Ground-wate $r$ - s a m pling protocols recommend the purging of wells prior to sampling because the quality of water standing in the casing is assumed to be nonrepresentative of water within surrounding geologic media. Two procedures used to ensure that a well has been purged sufficiently to yield "representative" samples are (1) evacuating an arbitrary number of casing volumes (usually three for wells that recover rapidly and one for wells that recover slowly, sampling occurs 24 hours after purging); and (2) pumping the well until field-measured values of temperature, $\mathrm{pH}$, specific conductance and/or dissolved oxygen in the purged water stabilized.
Two studies examined the validity of these procedures for the measurement of concentrations of volatile organic compounds (VOCs) in ground-water samples. In the first study, each of six rapidly recovering observation wells finished in sands and gravels was found to require removal of a unique, reproducible number of casing volumes before VOC concentrations stabilized. More than three casing volumes were required to stabilize 54 percent of the VOC concentrations. The medians of the casing volumes required for stabilization of VOC concentrations and field waterquality measurements were 3.0 and 1.7, respectively. The two medians were significantly different from each other.
In the second study, water samples from 11 wells finished in glacial tills were collected before purging and at several time intervals up to $\mathbf{4 0}$ hours after purging. Temperature, $\mathrm{pH}$, and specific conductance were constant; however, concentrations of VOCs changed dramatically with time, primarily due to volatilization losses. The optimal sampling time was defined as the time when VOC concentrations were greatest. Concentrations of VOCs were statistically higher after purging than before. VOC concentrations generally increased during the first 6 hours of recovery and then slowly decreased to the concentration measured before purging, but this variation was not statistically significant.

*Presenting author. 


\title{
THE EFFECTS OF LAND-MANAGEMENT PRACTICES ON SURFACE- AND GROUND-WATER QUALITY IN RURAL NORTHEASTERN GUILFORD COUNTY, NORTH CAROLINA
}

\author{
Catherine L. Hill \\ U.S. Geological Survey \\ Post Office Box 2857 \\ Raleigh, North Carolina 27602
}

An investigation to document the effects of land-management practices on water quality and soil erosion was started in 1985 in Guilford County, North Carolina. The four basins selected for study include a forested control basin that represents background conditions, a rural mixed land-use basin currently under standard land-management practices, and two cultivated basins. One cultivated basin is farmed under best land-management practices; the other is farmed under standard land-management practices. The cultivated basins are monitored for selected water-quality constituents in precipitation, runoff, and ground water. Surface water from all four basins and ground water and soil from the two cultivated basins are monitored for selected organic compounds. Results indicate that nitrate/nitrite concentrations in surface-water storm runoff at the control site average 0.12 milligrams per liter. In contrast, average nitrate/nitrite concentrations at the cultivated basin under standard land-management practice are almost 7 times greater than average concentrations at the control basin. The same increase is seen in suspended-sediment concentrations in surface-water storm runoff. Concentrations average 400 milligrams per liter at the control site but are 7 to 8 times greater in the cultivated basin under best land-management practices and more than 30 times greater in the cultivated basin under standard land-management practices.

\section{EXTENT OF PESTICIDE CONTAMINATION OF GROUND WATER IN THE UNITED STATES}

\author{
Patrick W. Holden \\ Ground-Water Section Head \\ Environmental Fate and Ground Water Branch \\ Office of Pesticide Programs \\ U.S. Environmental Protection Agency \\ Washington, DC 20460
}

A recently developed EPA data base of ground-water monitoring studies performed throughout the United States indicates that a significant number of pesticides associated with normal field applications as well as "point sources" have been detected in ground water. Currently, EPA estimates that 46 pesticides whose origin is believed to be normal field applications have occurred in the ground water of 26 States; additionally, 32 pesticides whose origin is believed to be "point sources" have been detected in the ground water of 12 States. [Note: It is expected that these numbers will increase prior to the November symposium.]

Information will be presented on the types of studies included in the EPA data base, efforts made to assess the data's quality, the frequency of detection and concentration levels of those pesticides found in ground water and the geographical extent of contamination. Information will be included on the environmental fate characteristics of specific pesticides to illustrate the relationship between physical/chemical properties of a given pesticide and its potential to leach to ground water.

A description of the types of ground-water monitoring studies required of agricultural chemical companies by the EPA will be discussed. 


\title{
A COMPARISON OF RESULTS FROM FIXED-INTERVAL AND STORM-BASED SAMPLING AT A CALIBRATED WATERSHED IN THE GEORGIA PIEDMONT
}

\author{
Richard P. Hooper* and Norman E. Peters \\ U.S. Geological Survey \\ Water Resources Division \\ 6481-B Peachtree Industrial Blvd. \\ Doraville, Georgia 30360
}

\author{
James B. Shanley \\ U.S. Geological Survey \\ Water Resources Division \\ 28 Lord Road \\ Marlborough, Massachusetts 01752
}

\begin{abstract}
Estimates of solute mass export from calibrated watersheds have relied on fixed-interval sampling, typically with samples taken once per week. Recent advances in instrumentation and microcomputer capabilities, however, have made it feasible to sample intensively during storms (i.e., every few minutes). Three years of storm-based data, consisting of more than 1,100 samples, have been collected at Panola Mountain, a 41-hectare catchment 25 kilometers southeast of Atlanta, Georgia, to determine whether storm-based sampling provides additional insight into the biogeochemical mechanisms controlling surface-water chemistry. Concentrations of
\end{abstract}

major anions, cations, and silica have been measured in all samples. Estimates of mass flux calculated from weekly samples are roughly the same as those calculated from the storm samples for solutes that dilute with increasing discharge, such as sodium and silica. However, mass flux calculated from weekly samples underestimates the transport of nitrate, sulfate, and hydrogen ions. Storm-based sampling better characterizes the chemical nature of runoff from the watershed during high flow when a substantial portion of the transport of these acidic solutes occurs. These observations are also indicative of features required for the development of predictive mechanistic models, such as an accurate representation of flowpaths through the catchment. Even on a simpler statistical level, multiple linear regression models developed from this data set which predict concentration from discharge and other physical variables have yielded unexpected results. For example, the six-month cumulative precipitation is a necessary independent variable for sodium. The need for such a long accumulation period is surprising for this small watershed. This data set provides a basis for the development of hydrochemical models that will more fully capture the chemical dynamics of these systems than those typically used in the past.

*Presenting author.

\section{MODELING AQUATIC SEDIMENT-ASSOCIATED TRACE ELEMENT CONCENTRATIONS USING SELECTED GEOCHEMICAL FACTORS}

\author{
Arthur J. Horowitz*, Kent A. Elrick, and Richard P. Hooper \\ U.S. Geological Survey \\ Water Resources Division \\ 6481-B Peachtree Industrial Blvd. \\ Doraville, Georgia 30360
}

Multiple linear regression models calculated from readily obtainable chemical and physical parameters can explain a high percentage (70 percent or greater) of observed sediment-trace element variance for copper, zinc, lead, chromium, nickel, cobalt, arsenic, antimony, selenium, and mercury in a widely divergent suite of 61 sediment samples. The independent variables used in the models may be single parameters, principal component scores, or principal component scores combined with their cross-products. The most useful type of variable must be determined on a case-by-case basis.

The independent variables (geochemical parameters) incorporated in the models calculated during this study probably are applicable to many aquatic sediments; albeit, use of a larger data set (more than 61) could alter the magnitude of the calculated coefficients. The geochemical parameters included in the models were of a physical (for example, grain size, surface area) and a chemical (for example, organic matter, amorphous iron 
oxides) nature. Comparison between actual and predicted trace element concentrations obtained from the models may provide a means of defining "average" sediment-trace element concentrations. In this context, the models may also help identify either naturally or anthropogenically impacted sites for additional study.

- Presenting author.

\title{
SEDIMENT-WATER INTERACTION DURING ARTIFICIAL RECHARGE THROUGH AN ORGANIC MAT
}

\author{
G. F. Huff \\ U.S. Geological Survey \\ P. O. Box 66492 \\ Baton Rouge, Louisiana 70896
}

donor capacities up to 350 times that of carbonic acid. In addition, volatile fatty acid anions form highly-soluble complexes with calcium and magnesium. Dolomite dissolves into $\mathrm{CO}_{2}$ charged water very slowly, even in strongly undersaturated solutions. Dissolution of dolomite, starting after approximately $\mathbf{4 0 0}$ hours of basin operation, strongly suggests the action of a corrosive agent absent in the subsurface until that time. Generation of organic acids during oxidative degradation of the organic mat after approximately $\mathbf{4 0 0}$ hours of basin operation would account for the dissolution of dolomite.
Mineral-stability calculations using the inorganic speciation model WATEQF showed including volatile fatty acids. Volatile fatty acids have proton

\section{HYDROGEOLOGIC CONTROLS ON THE DISTRIBUTION OF RADON-222 IN GROUND WATER OF WEST-CENTRAL NEVADA}

\author{
Jennifer L. Hughes, ${ }^{*}$ Michael S. Lico, and Alan H. Welch \\ U.S. Geological Survey \\ Water Resources Division \\ Nevada District Office \\ Room 227, Federal Building \\ Carson City, Nevada 89701
}

Radon-222 ( $\left.{ }^{222} \mathrm{Rn}\right)$ activities in ground-water samples from aquifers in west-central Nevada were interpreted to identify the possible controls on the areal distribution of ${ }^{222} \mathrm{Rn}$. The ${ }^{222} \mathrm{Rn}$ activities in 154 ground-water samples ranged from less than 80 to $16,000$ picoCuries per liter ( $\mathrm{pCi} / \mathrm{L})$, and had a median activity of 870 $\mathrm{pCi} / \mathrm{L}$. The highest ${ }^{222} \mathrm{Rn}$ activities are in ground water from alluvialfan deposits along the eastern slopes of the Carson Range in western Carson Valley (median, $760 \mathrm{pCi} / \mathrm{L}$ ) and Eagle Valley (median, 2,000 pCi/L), from alluvial and colluvial deposits in the eastern part of the adjacent Lake Tahoe basin (median, 2,350 pCi/L), and from the granitic bedrock of the Carson Range (single sample, $14,000 \mathrm{pCi} / \mathrm{L})$. The ${ }^{222} \mathrm{Rn}$ activities decrease eastward from the Carson Range to a median value of 622 pCi/L in the Carson Desert (about 50 miles east of the Carson Range). 
Possible sources of high ${ }^{222} \mathrm{Rn}$ activities in ground water of west-central Nevada include: (1) Cretaceous granitic rocks of the Carson Range that contain uranium concentrations as high as 10 milligrams per kilogram (mg/kg), and their sedimentary derivatives, (2) high- ${ }^{222} \mathrm{Rn}$ ground water moving upward along a major fault zone bounding the west side of Carson and Eagle Valleys, and (3) high concentrations of uranium in organic-rich sediments along the west side of Carson Valley (up to $53 \mathrm{mg} / \mathrm{kg}$ ), within the Carson Range (up to $1,660 \mathrm{mg} / \mathrm{kg}$ ), and in stream valleys on the east side of the Lake Tahoe basin (up to $2,500 \mathrm{mg} / \mathrm{kg}$ ).

"Presenting author.

\title{
GROUND-WATER CHEMISTRY AT THE BUILDING 24 RESEARCH SITE PICATINNY ARSENAL, NORTH-CENTRAL NEW JERSEY
}

\author{
Thomas E. Imbrigiotta* and Patrick J. Witkowski \\ U.S. Geological Survey \\ 810 Bear Tavern Road, Suite 206 \\ West Trenton, New Jersey 08628
}

The U.S. Geological Survey is conducting an interdisciplinary research study of ground-water transport of chlorinated solvents and other contaminants at Picatinny Arsenal in north-central New Jersey. A variety of chemicals including trichloroethylene, chromium, copper, cadmium, zinc, cyanides, and sulfuric acid were used in a metal degreasing/plating operation in Building 24. Wastedisposal practices associated with this operation have contaminated ground water primarily within a 50-foot thick unconfined sand and gravel aquifer in a zone that extends 1,650 feet downgradient from Building 24 to Green Pond
Brook, a point of ground-water discharge.

The areal and vertical distributions of trichloroethylene and sulfate in the unconfined aquifer are similar, suggesting that organic and inorganic compounds have sources in the Building 24 area and that both tend to be transported along similar flow paths to Green Pond Brook. The plume of contaminated water starts at the water table near the source. Because of density differences, the depth of the plume increases with increasing distance downgradient from the source. The plume then moves upward where it discharges to Green Pond Brook.
Chemical characterization of the contaminated ground water has shown that (1) biodegradation of chlorinated solvents is occurring downgradient from Building 24 , as evidenced by methane production and the presence of cis-1,2-dichloroethylene and vinyl chloride, which are breakdown products of trichloroethylene; (2) dissolvedorganic-carbon concentrations greater than 10 milligrams per liter are present only within 500 feet of the source and are not derived from priority-pollutant organic compounds; and (3) detectable tracemetal and cyanide concentrations are present as far as $\mathbf{5 0 0}$ feet and 900 feet downgradient from the source, respectively.

-Presenting author.

CHEMICAL CONTAMINANTS IN THE ENVIRONMENT: ROLE OF THE FISH AND WILDLIFE SERVICE'S ENVIRONMENTAL CONTAMINANTS FIELD OPERATIONS PROGRAM

\author{
Gerry Jackson \\ U.S. Fish and Wildlife Service \\ Division of Environmental Contaminants \\ Mail Stop 330, Arlington Square \\ Washington, DC 20240
}

The Fish and Wildlife Service's environmental contaminants field operations program was established in the early 1980 's to ascertain the extent and magnitude of toxic chemicals in the environment and to assess their impact on fish, wildlife and their habitat. The primary goals of this program are to effect remediation of existing contaminant problems, obtain mitigation for natural 
resource damages and help prevent future impacts to fish and wildlife. Particular emphasis is directed towards contaminant problems affecting the Service's trust resources, such as migratory birds, endangered species and anadromous fish, as well as problems threatening the more than 450 National Wildlife Refuges that encompass approximately 90 million acres of land. This goal is being accomplished with a cadre of field contaminants specialists located in 51 field offices, seven regional offices and a central office in Washington, D.C. Through the use of state-of-the-art bioassessment tools, in conjunction with chemical residue determination, environmental contaminants specialists conduct baseline and comprehensive field investigations. Additionally, Service contaminants specialists consult informally and formally through various legal authorities, such as the Migratory Bird Treaty Act, Endangered Species Act, National Environmental Policy Act, and the Clean Water Act among others, with other Federal and State agencies and the private sector to eliminate, or at least minimize, the impacts of contaminants on the environment.

\title{
THE ANAEROBIC BIOREMEDIATION OF TCE CONTAMINATED AQUIFERS: A FEASIBILITY STUDY
}

\author{
Peter R. Jaffe'*, Stewart W. Taylor, and Naresh Singhal \\ Department of Civil Engineering and Operations Research \\ Princeton University \\ Princeton, New Jersey 08544
}

Bioremediation of contaminated aquifers is usually applied when the contaminants are a growth substrate. In these cases, limiting nutrients and oxygen are injected into the aquifer through recharge wells to enhance biodegradation of these pollutants. Aquifers contaminated with pollutants that are not growth substrates, but that can be degraded co-metabolically, also require the injection a growth substrate. A problem here is that bacteria will degrade the substrate consuming the oxygen in the vicinity of the well, making it difficult to bring all required components in contact with the pollutant throughout the contaminated region.
To circunivent this problem, an anaerobic process is investigated. Experimental results showed that TCE and its intermediates can be degraded under methanogenic conditions, and that the rate is a function of the methanogenic activity. Simulations based on these results show that TCE contaminated aquifers could be bioremediated if the methanogenic activity is increased through the supplementation of a growth substrate. As opposed to the aerobic scenario where biological activity is limited by the quantity of oxygen injected, no such limitation exists for the anaerobic scenario. A consideration in determining what level of methanogenic activity can be achieved is the reduction in the aquifer permeability due to the accumulation of biomass and methane gas.

Changes in permeability as a function of the biomass accumulation and the methane saturation are simulated using a modification of the Mualem permeability model, which has been verified experimentally.

Combining the results of the TCE degradation experiments, and the permeability model, simulations are conducted to illustrate the TCE biodegradation for different methanogenic levels, and the correspondent reduction in permeability.

*Presenting author.

\section{A FLOW MODEL BASED ON THE DIFFUSION ANALOGY}

\author{
Harvey E. Jobson \\ U.S. Geological Survey \\ Water Resources Division \\ Office of Surface Water, 415 National Center \\ Reston, Virginia 22092
}

A computer model for routing streamflow through a system of channels using the diffusion analogy in conjunction with a Lagrangian solution scheme is presented. The model is designed to provide predictions of hydraulic properties using a minimum of field data and calibration. One- 
dimensional flow theory, algorithms used in the model, and two example applications of the model are presented. The model outputs time-step-averaged values of discharge at grid points and instantaneous reach-averaged values of cross-sectional area and top width. These values can then be used as input to a transport model for a system of one-dimensional channels. In combination with a transport model, the flow model functions as the basis for routing a large variety of water-quality constituents through stream systems. The model cannot be used where flow reversals occur and is most accurate for upland streams where backwater conditions are minimal. The model requires the input of three coefficients for each subreach that have the form of hydraulic geometry coefficients. These values have been found to be fairly predictable and consistent for streams throughout the country. Appendixes discuss programs for constructing input files, determining input coefficients, and interfacing of the model with a Branched Lagrangian Transport model.

\title{
CONTAMINATION OF GROUND AND SURFACE WATER BY AGRICULTURAL CHEMICALS, BIG SPRING BASIN, CLAYTON COUNTY, IOWA
}

\author{
Stephen J. Kalkhoff \\ U.S. Geological Survey \\ Rm 269, Federal Building \\ 400 South Clinton Street \\ Iowa City, Iowa 52244
}

The quality of ground and surface water was monitored in Big Spring ground-water basin from March to December 1988. Water quality in the 103-square-mile karstic basin is affected by agricultural chemicals. Samples were collected at Big Spring, the site of nearly all groundwater discharge, and at Roberts Creek, the primary surface-water drainage in the basin. Seasonal variations of nitrate concentrations in Big Spring and Roberts Creek were similar; generally largest in the late spring and early summer and then declining in late summer and fall. Nitrate (as nitrogen) concentrations varied less in Big Spring (7.1 to 11 milligrams per liter) than in Roberts Creek ( 0.2 to 15 milligrams per liter). The number and concentration of herbicides detected were larger in Roberts Creek than in Big Spring. Atrazine was detected in all samples from Roberts Creek and in eight of ten samples from Big Spring. Atrazine was the only pesticide detected in Big Spring, but three additional herbicides, cyanazine, alachlor, and metolachlor, were detected in Roberts Creek. The largest number and concentrations of herbicides in Roberts Creek were found in a sample in early October, 2 weeks after the largest rainfall of the year. Four herbicides, atrazine, cyanazine, alachlor, and metolachlor, were detected in this sample in concentrations ranging from 0.26 to 2.9 micrograms per liter. This observation indicates that even after 4 months of drought, herbicides were still present.

\section{A LONG-TERM PRECIPITATION MONITORING PROGRAM FOR THE UNITED STATES}

\author{
F. Paul Kapinos \\ U.S. Geological Survey \\ Water Resources Division \\ Office of Atmospheric \\ Deposition Analysis \\ 12201 Sunrise Valley Drive \\ Reston, Virginia 22092
}

The National Trends Network (NTN) for monitoring precipitation chemistry in the United
States was developed under the sponsorship of the U.S. Geological Survey, as lead agency for deposi- tion monitoring under the National Acid Precipitation Assessment Program. The operation and 
funding support for the NTN are currently a multiagency Federal/State/private-sector effort. The Geological Survey has proposed to assume responsibility for managing and funding the program beginning in FY 1991.

The NTN consists of 150 -stations located predominantly in rural areas, but in combination with the National Atmospheric Deposition Program (NADP), includes more than 200 sites nationwide. The weekly-collected samples are analyzed at a central laboratory for $\mathrm{pH}$, specific conductance, and the major anions and cations. External quality assurance is provided by the Geological Survey's Branch of Quality Assurance. Internal quality assurance is provided at both the laboratory and the NTN Coordinator's Office at Colorado State University. The data are stored at the Battelle Northwest National Laboratory.

Data summaries produced annually by the Coordinator's Office include annual average isopleth maps for all major constituents. Comparisons of annual isopleth maps suggest no striking changes in the $\mathrm{pH}$ of precipitation or in the concentrations or deposition of sulfate or nitrate over the past 8 years.

The Geological Survey proposed network for FY 1991 would consist of about 175 stations--the present 150-site NTN plus 25 selected sites currently operated by other Federal agencies and the States. Plans provide for continued multiagency participation; however, Geological Survey Offices will be called on to provide additional support for the network.

\title{
AQUEOUS GEOCHEMISTRY OF THE SAND-AND-GRAVEL AQUIFER AND THE FLORIDAN AQUIFER SYSTEM, FLORIDA
}

\author{
Brian G. Katz*, Anne F. Choquette, and Ruth M. Roaza \\ U.S. Geological Survey \\ 227 North Bronough Street, Suite 3015 \\ Tallahassee, Florida 32301
}

The aqueous geochemistry of the sand-and-gravel aquifer and the Floridan aquifer system was characterized as part of the Ambient Ground Water Monitoring Program in Florida, a multi-agency cooperative study delineating background water quality for the major aquifer systems throughout the State. The sand-and-gravel aquifer, the principal source of water in northwestern Florida, consists predominantly of quartz sand with smaller amounts of andesine, chlorite, calcite, kaolinite, and illite. Water from 39 wells tapping the aquifer characteristically was of nondistinct water type with a median dissolved solids concentra- tion of 73 milligrams per liter. Based on statistical comparisons, the chemistry of the water does not change significantly ( 0.05 level) as it moves vertically and laterally through the aquifer. Mass-balance modeling suggests that the background chemistry of water in the aquifer is controlled primarily by the incongruent solution of andesine and muscovite to form kaolinite, with a much smaller contribution from the solution of calcite and chlorite.

The Floridan aquifer system, a thick sequence of hydraulically connected limestone and dolomite beds, provides 460 million gallons per day of freshwater for public supply throughout the State. The major-ion chemistry of water from 1,075 wells tapping the aquifer system changes spatially as the water moves along extensive flow paths. The system is dominated by several distinct hydrochemical facies, two of which are calciumbicarbonate and calcium/magnesium-bicarbonate due primarily to the dissolution of calcite and dolomite, respectively. In areas near the freshwatersaltwater interface, sodiumchloride is the predominant facies resulting from the mixing of freshwater with recent or residual seawater.

*Presenting author. 


\section{STABLE CARBON-ISOTOPE RATIOS AS TRACERS OF SOURCES OF ALKALINITY IN SMALL WATERSHEDS}

\author{
Carol Kendall \\ U.S. Geological Survey \\ National Research Program, NR \\ 431 National Center \\ Reston, Virginia 22092
}

\begin{abstract}
Stable carbon-isotope ratios have become a popular tool in groundwater geochemistry studies because they provide an additional constraint on geochemical massbalance models. Under favorable circumstances, carbon isotopes may be used in surface-water geochemistry studies for a similar purpose. In small watersheds, the delta C-13 value of stream bicarbonate can be used for the semi-quantitative determination of the temporal and spatial variations in the relative contributions of several biogeochemical reactions that produce bicarbonate. The
\end{abstract}

method requires that the delta C-13 values of all potential sources and sinks of carbon in the watershed be known, and that biological uptake and atmospheric isotopic exchange be minimal.

The carbon-isotopic composition of stream bicarbonate was measured over 2 years at two creeks at Catoctin Mountain, Maryland. The bicarbonate content and its delta $C-13$ value showed strong seasonal variation in both watersheds caused by seasonal variations in the contributions of carbon from calcite and soil carbon dioxide. A carbon mass-balance model was used to calculate that about 90 percent of the bicarbonate in winter is derived from calcite. About 50 to 90 percent of this calcite dissolution is due to attack of strong acids, with the remainder from carbonic-acid weathering of calcite. During the summer, about 60 percent of the bicarbonate is derived from carbonic acid. Seasonal and temporal variations in alkalinity and delta $\mathrm{C}-13$ value are caused primarily by variations in soil biological activity.

\section{DETECTION OF COLLOIDS BY ULTRAFILTRATION DOWNSTREAM FROM ACID MINE DRAINAGE, UPPER ARKANSAS RIVER, COLORADO}

\author{
Briant A. Kimball* and Gregory A. Wetherbee \\ U.S. Geological Survey \\ Colorado District \\ M.S. 415, Denver Federal Center \\ Denver, Colorado 80225
}

\author{
E.C. Callender \\ U.S. Geological Survey, WRD \\ Northeast Region, NRP \\ M.S. 412, National Center \\ Reston, Virginia 22092
}

\author{
Ellen Axtman \\ U.S. Geological Survey, WRD \\ Western Region, NRP \\ M.S. 465, 345 Middlefield Road \\ Menlo Park, California 94025
}

Metal-rich, acidic water drains from mines and tailings piles in the Leadville, Colo., area and mixes with near neutral $\mathrm{pH}$ water in the Arkansas River. The change in $\mathrm{pH}$ results in the formation of colloidal iron oxyhydroxides that are transported downstream, mostly in suspension. To determine the extent of colloidal transport, samples were collected at gages in a 250-kilometer reach downstream. Ultrafiltration, using a 100,000 molecular-weight nominal pore-size membrane, and standard filtration, using a 0.45 -micrometer pore-size membrane, indicated large differences in iron concentrations between filtrates. Iron concentrations in the 0.45 micrometer filtrate generally were 10 times greater than in the ultrafiltrate at each site. The difference was even greater in the sample just downstream from California Gulch where colloids are chemically and visibly evident. Filterable concentrations of cadımum, copper, manganese, and zinc were less than analytical detection limits in most of the Arkansas River samples, but unfiltered concentrations indicated that 
metals are present in association with the colloids. The ratios of cadmium, manganese, and zinc to iron were 10 times greater in samples of colloids from the Arkansas River than in those from California Gulch. Most metal transport in the Arkansas River occurs during snowmelt runoff, when colloidal material is flushed from channel storage. Because colloids can pass through the 0.45-micrometer filters, colloid associated metal concentrations are often reported as dissolved metal concentrations. Ultrafiltration of samples from metal-rich streams, prepares filtrates that more accurately measure the truly dissolved metal concentrations that are needed for chemical equilibrium calculations. * Presenting author.

\section{TESTING SAMPLING DESIGN METHODS USING THE CAPE COD, MASSACHUSETTS TRACER TEST DATA AND ONE-DIMENSIONAL TRANSPORT MODELS}

Debra S. Knopman* and Clifford I. Voss

U.S. Geological Survey

410 National Center

Reston, Virginia 22092
Stephen P. Garabedian

U.S. Geological Survey

28 Lord Road, Suite 208

Marlborough, Massachusetts 01752
Sampling design methods to determine location of observation wells and sampling frequency for the objectives of model discrimination, parameter estimation, and cost minimization were tested on bromide measurements collected at the Cape Cod, Massachusetts tracer test site between July 1985 and December 1986. The goal of model discrimination is to identify models that fit the observations well and accurately predict future observations. The goal of parameter estimation is to estimate model parameters with low bias and variance and hence minimal uncertainty.

Testing of the design methodology was performed on one-dimensional forms of the advection-dispersion equation. Four onedimensional transport models were hypothesized and two error forms were assumed for each of the models. By using nonlinear regression, eight models were fitted to data sets varying in their number of observations and method of well selection. To carry out the onedimensional analysis, the dense three-dimensional set of measurements was aggregated by vertically averaging observations at each well. From this array, a one-dimensional set of "observations" was formed by choosing in each sampling period the maximum vertically-averaged concentration within each row of wells perpendicular to flow.

In terms of the objective of model discrimination, results show that the sampling design methodology identified sparse designs (less than 50 points in time and space) that perform as well as dense designs that use all available verticallyaveraged "observations" (521 points). Conversely, the same models best fit the observations in the sparse designs as did those using the full observation set. In addition, splitting the data sets into two time periods allowed for testing of the predictive accuracy of models. The sparse designs produced the same ordering of models in terms of their predictive power as did the full set of observations. These same sparse designs were also more effective in discrimination than arbitrarily chosen designs with the same number of points. Observation sets specifically designed for the objective of parameter estimation were effective in producing estimates of parameters with lower variance than arbitrarily chosen designs with the same number of observation points.

Presenting author. 
Dana W. Kolpin* and Michael R. Burkart

U.S. Geological Survey

Water Resources Division

400 South Clinton

Iowa City, Iowa 52244

Variables representing geologic, hydrologic, water-chemistry, soil, and well-construction factors were examined to determine the principal indicators of pesticide occurrence in shallow (within 61 meters of land surface) aquifers in Iowa. Linear and logistic regression were used to analyze data compiled from 373 municipal wells. In the initial model, the most statistically significant indicator of pesticide occurrence was the thickness of unconsolidated material (drift) overlying an aquifer. More accurate estimates of occurrence were possible when the data were divided into two groups on the basis of the thickness of unconsolidated material overlying the aquifer. Two new predictive models, the thin-drift model (less than 12 meters of drift) and thick-drift model (greater than 12 meters of drift), were generated. The larger number of factors (15) required to define the thick-drift model, more than twice that required by the thin-drift model, indicates that accurately predicting pesticide occurrence in more deeply buried aquifers may require understanding of more numerous or complex processes. Nitrate concentration in ground water is a factor which, by itself, can be used to estimate the occurrence of pesticides for an aquifer with thin overlying drift. No single indicator was able to predict the occurrence of pesticides in aquifers with thick overlying drift.

* Presenting author.

\section{EVALUATING NONPOINTSOURCE CONTAMINANTS IN THE CONESTOGA HEADWATERS, PENNSYLVANIA}

The Conestoga Headwaters Rural Clean Water Project was designed to define nonpointsource contaminants in an agricultural area in the headwaters of the Conestoga River, Pennsylvania and to evaluate changes in surface- and groundwater quality resulting from the voluntary implementation of agricultural best management practices in the area. The study area consisted of a regional waterquality sampling network (188 square miles), a small watershed (5.8 square miles), and two fieldsites ( 23 and 48 acres). The study evaluated the effects of nutrient management, manure storage, and terracing on nutrient,
Kevin M. Kostelnik

U.S. Geological Survey

Water Resources Division

P.O. Box 1107

Harrisburg, Pennsylvania 17108

suspended-sediment, and pesticide concentrations and loads.

Ground water from domestic wells in agricultural areas underlain by carbonate rock was found to be more susceptible to contamination than ground water from nonagricultural, noncarbonate areas. Pesticides were most prevalent in water samples from these wells, and nitrate concentrations typically exceeded U.S. Environmental Protection Agency maximum contaminant levels for drinking water. Median concentrations of total nitrogen increased from 3.2 to 9.1 milligrams per liter within a 1-mile reach as the stream flowed from a forested noncarbonate terrain into an agricultural valley underlain by carbonates. A paired-watershed trend analysis indicated that surface-water quality appears to have improved as the result of nutrient management implementation, but that improvement may not be significant for several years because of elevated nitrate concentrations in the soil. One field-site study has shown that terracing decreased erosion and sediment concentrations in surface runoff but caused an increase in dissolved-nitrate concentrations in both ground water and surface runoff following terrace installation. This increase may result from an increase in contact time with the nutrient-rich surface and soils. 


\author{
T. F. Kraemer \\ U.S. Geological Survey \\ 431 National Center \\ Reston, Virginia 22092
}

Radium $(\mathrm{Ra})$ is present in surface waters as a result of natural weathering processes and human activities. At Taft, La., radium-rich waste from phosphate fertilizer production was discharged directly into the Mississippi River, resulting in a point-source addition of considerable radium with a ${ }^{228} \mathrm{Ra} /{ }^{226} \mathrm{R}$ a-activity ratio significantly different from that of the river water. By observing the mixing of the waste with the river-water/suspended-sediment system, the chemistry of radium in riverine environments can be understood. On the basis of this study, it is estimated that the flux of radium from the Mississippi River to the Gulf of Mexico is $0.98 \times 10^{14}$ $\mathrm{dpm} / \mathrm{yr}$ (disintegrations per minute per year) without the fertilizer waste and $2.44 \times 10^{14} \mathrm{dpm} / \mathrm{yr}$ when the river is receiving the waste. The flux is $\mathbf{4 5}$ percent in the dissolved state and 55 percent in the absorbed state on suspended sediment. Chemical and isotopic reequilibration of the river is achieved within 3 hours (and 13 kilometers) after the waste addition. The water and sediment of the river below the waste-disposal site retain the new radium isotopic signature at least to Venice, $\mathbf{L a}$.

\section{WATER QUALITY INVESTIGATIONS IN THE U.S. VIRGIN ISLANDS}

\section{J. Hari Krishna* and Robert H. Ruskin Water Resources Research Center University of the Virgin Islands \\ St. Thomas, Virgin Islands 00802}

In the U.S. Virgin Islands, cisterns are commonly used to store water for domestic consumption. The water collected in the cisterns could be from various sources such as rooftop runoff, ground water and desalinated water.

Several studies have been conducted during the past few years to investigate the water quality in the Virgin Islands. The studies indicate that generally, the water is acceptable in terms of chemical constituents but does not meet bacteriological standards as set forth in the U.S.E.P.A. Safe Drinking Water Act. Since most private cisterns serve less than 25 people they are exempt from the mandates of the Safe Drinking Water Act, yet they could be contaminated and cause serious water-borne infections.

In a study of 20 private residential cisterns, it was found that if only overall averages were considered, not one of them would have met the Safe Drinking Water standard of $\leq 1$ total coliform $/ 100 \mathrm{~mL}$, and only four of the 20 would have met this standard at least 50 percent of the time.

In another water quality study, ten cisterns were evaluated at five public housing projects. The results showed that only half the samples collected over a 10-month period were in compliance with the mandates of the Safe Drinking Water Act. Proper cistern maintenance coupled with adequate chlorination is essential in maintaining the water quality for domestic use in the Virgin Islands.

*Presenting author. 


\section{MODIFICATION OF THE QUAL2E WATER-QUALITY MODEL FOR APPLICATION TO SMALL FOOTHILL STREAMS NEAR PIKES PEAK, COLORADO}

\author{
Gerhard Kuhn \\ U.S. Geological Survey \\ 503 N. Main, \#207-W \\ Pueblo, Colorado 81003
}

Modifications to the U.S. Environmental Protection Agency's QUAL2E water-quality model were made during calibration and verification of the model for Fountain and Monument Creeks, which flow along the Front Range near Pikes Peak, Colorado. The following modifications were most notable: (1) The capability to use a different computationalelement length for each subreach was added; this enabled more precise positioning of the numerous tributaries, diversions, and point sources, while keeping the total number of computational elements reasonable. (2) Use of the model indicated that simulated temperature was not sensitive to the dust-attenuation coefficient or the fraction of cloud cover, which were varied by subreach; consequently, the model was modified to enable variation of the evaporation coefficients by subreach, to which simulated temperature was sensitive. (3) A subroutine was added to compute an estimated un-ionized ammonianitrogen concentration based on model-computed temperature, dissolved-solids concentration, and total ammonia-nitrogen concentration and subreach $\mathrm{pH}$ values specified in the model input.
(4) The capability to output hineprinter plots of the constituents being modeled also was added to the model; originally, only biochemical-oxygen demand and dissolved oxygen were output, both on a single line-printer plot. This last modification was beneficial in model calibration and verification for Fountain and Monument Creeks and would be useful in computer systems that lack graphics capabilities. These and other modifications improved the operational flexibility of the QUAL2E model, while maintaining all the original computational methods.

\section{HYDROLOGIC AND GEOLOGIC FACTORS AFFECTING THE SHAPE OF A SEWAGE PLUME ON CAPE COD, MASSACHUSETTS}

Disposal of treated sewage to a sand and gravel aquifer on Cape Cod, Massachusetts, since 1936 has formed a plume of contaminated ground water that is 600 to 900 meters wide, 23 meters thick, and more than 4 kilometers long. The plume, which contains elevated levels of nitrate, boron, detergents, and other contaminants present in the treated sewage, is overlain by 6 to 15 meters of uncontaminated ground water.

Because transport of solutes in the plume is dominated by advection, the longitudinal axis of the

\author{
Denis R. LeBlanc \\ U.S. Geological Survey \\ 28 Lord Road, Suite 280 \\ Marlborough, Massachusetts 01752
}

plume is alined in the direction of ground-water flow as inferred from the water-table gradient. Transverse mixing by dispersion is limited, particularly in the vertical direction, so the boundaries of the plume are sharp, and steep concentration gradients are present within the contaminated zone. Because of the limited vertical mixing, areal recharge from precipitation forms the zone of uncontaminated ground water above the plume. The upper part of the plume along its eastern side discharges to a pond located 500 meters from the disposal site; as a result, the contaminated zone has an asymmetric cross section south of the pond. Near its toe, part of the plume enters finer grained, less permeable sediments that underlie the sand and gravel; the difference in permeability causes the contaminants to move at different rates in the two lithologic units. These observations indicate that limited vertical mixing and hydrologic and geologic controls on advective transport are the main factors affecting the shape of the sewage plume. 


\title{
DETERMINATION OF THE EXTENT OF GASOLINE CONTAMINATION OF A SHALLOW SAND AQUIFER USING SOIL GAS ANALYSES FOR VOLATILE ORGANIC COMPOUNDS IN JACKSON, TENNESSEE
}

\author{
Roger W. Lee \\ U.S. Geological Survey \\ Tennessee District \\ A-413 U.S. Courthouse \\ 801 Broadway \\ Nashville, Tennessee 37203
}

Soil gas analyses of the unsaturated zone provided a rapid and low cost approach to determining the extent of gasoline contamination of a shallow watertable aquifer. An underground tank in Jackson, Tennessee leaked about 8,000 gallons of unleaded gasoline from 1980 to 1988 . The gasoline leaked to the water table about 4 feet below land surface. A survey of soil gas using a gas chromatograph equipped with a photoionization detector showed concentrations of volatile organic compounds greater than 10,000 parts per million near the leak. The contaminant plume was about 240 feet long and $\mathbf{1 1 0}$ feet wide extending west from the point source. Two "fingerprints" of volatile organic compounds were observed in the chromatograms. Benzene, toluene, and xylenes were present from the unleaded fuel in addition to other volatile compounds in the area near the gasoline leak. Just north of the leak, volatile organic compounds containing no benzene, toluene, or xylenes were observed in soil gas samples. Mapping of total concentrations of volatile organic compounds in the unsaturated zone indicated that a second plume about 200 feet long and 90 feet wide, also extending to the west, was present about 100 feet north of the gasoline leak. Previous activities on this site during the 1950's or earlier, such as handling of solvents used at the nearby railyard, or flushing of tanks containing tar onto an unpaved parking area may have contributed volatile organic compounds to the second plume.

\section{POLYETHYLENE-GLYCOL RESIDUES FROM NONIONIC SURFACTANTS IN THE LOWER MISSISSIPPI RIVER}

\author{
J. A. Leenheer*, R. L. Wershaw, P. A. Brown, \\ and T. I. Noyes \\ U.S. Geological Survey-WRD \\ 5293 Ward Road \\ Arvada, Colorado 80002
}

Polyethylene-glycol residues were discovered in organic-solute isolates from the lower Mississippi River by hydrogen- 1 and carbon-13 NMR (nuclear magnetic resonance spectrometry) and specific colorimetric methods during assay of the dissolved organic carbon fraction. The hydrogen-1-NMR and the colorimetric assays for the polyethylene-glycol residues were done on river samples collected at 21 sites between St. Louis, Missouri, and New Orleans,
Louisiana, sampled in July-August and November-December 1987. The polyethylene glycols consisted of neutral and acidic residues that contained no evidence of intact nonionic surfactants which have polyethylene glycols bonded to linear-alcohol or alkylphenol moieties. Minimum concentrations for polyethylene-glycol residues, based on colorimetric assay, ranged from undetectable to 28 micrograms per liter. Maximum concentrations, based on hydrogen-1-NRM, ranged from undetectable to 145 micrograms per liter. Polyethylene-glycol residues were not detected in samples from only 2 of the 21 sites. The ubiquitous presence of polyethylene-glycol residues in Mississippi River samples may indicate a slower rate of degradation for these residues from nonionic surfactants than predicted by published laboratory studies.

*Presenting author. 


\title{
A RECONNAISSANCE STUDY OF THE DISTRIBUTION OF HALOGENATED ORGANIC COMPOUNDS IN CATFISH FROM THE LOWER MISSISSIPPI RIVER AND ITS TRIBUTARIES
}

\author{
Thomas J. Leiker*, Wilfred E. Pereira, Colleen E. Rostad \\ and Charles Barnes \\ U.S. Geological Survey \\ P.O. Box 25046, Mail Stop 408 \\ Denver Federal Center \\ Denver, Colorado 80225
}

\begin{abstract}
Water quality of a given water system is often established by determining the concentration of organic contaminants that are contained within the water column. In some instances, this approach may produce a false indication of acceptable water quality. Hydrophobic contaminants are often present in the watercolumn at concentrations that are below the detection limit (1 nanogram per liter) of conventional analytical techniques. These types of compounds usually have large octanol/water partition coefficients and are selectively
\end{abstract}

partitioned from the water column into bed sediments and are bioconcentrated within the lipid tissues of stream biota. This study assessed contaminant concentrations in water column and catfish tissue from the Mississippi River and its tributaries from Naples, Illinois to Belle Chasse, Louisiana. The data indicate that the water column contains relatively low concentrations of hydrophilic organic contaminants while the more hydrophobic compounds are not detected in the water column but bioconcentrate in the tissue of catfish.

Catfish from 16 locations along the Mississippi and its tributaries were collected and analyzed using capillary gas chromatography/mass spectrometry. Selected contaminants that have been identified include DDT and its metabolites, chlordane and tetrathrough octachlorobiphenyl. This paper will discuss the analytical methodology and the distribution of organic contaminants in catfish as they relate to the water quality of the Mississippi River.

*Presenting author.

\section{THE ANALYSIS OF ENVIRONMENTAL FACTORS CONTROLLING THE SPECIES COMPOSITION OF BENTHIC COMMUNITIES}

\author{
Harry V. Leland* and Steven V. Fend \\ U.S. Geological Survey \\ Mail Stop 465 \\ 345 Middlefield Road \\ Menlo Park, California 94025
}

It is often important to define the effects of environmental variables on the species composition of aquatic communities. Multivariate analyses, including hierarchial classification and ordination, have been effective in examining distribution patterns in benthic communities and these patterns can be examined in relation to environmental gradients. Results from three lotic ecosystem studies of widely differing scale are presented to illustrate the approach. Changes in the composition of benthic invertebrate communities in a Sierra Nevada stream due to an experimentallyimposed copper concentration gradient were defined. When pre-dose data for each sampling date were considered independently, substratum composition and biological interactions were the major gradients displayed in species ordinations. During periods of copper exposure, sensitivity of taxa to communities colonizing stable subtrates in the lower San Joaquin River, California, was found to be strongly related to the concentrations of dissolved solids and/or toxic constituents in riverwater, which was contaminated through subsurface drainage and irrigation return flows in the San Joaquin Valley. Altitudinal and/or temperature preferences of taxa were found to be important factors controlling the structure of benthic invertebrate communities in the Yakima River, Washington, which drains the eastern Cascades and the Columbia Basin.

*Presenting author. 


\title{
ROLE OF MODELS IN ADDRESSING AGRICULTURAL MANAGEMENT
} AND WATER QUALITY

\author{
Ralph A. Leonard \\ U.S. Department of Agriculture \\ Agricultural Research Service \\ Southeast Watershed Research Laboratory \\ P.O. Box 946 \\ Tifton, Georgia 31793
}

Pest control chemicals are valuable tools in providing reliable sources of food and fiber. However, their detection in surface and ground water is a matter of concern that cuts across numerous disciplines and government agencies. Research has provided valuable data and mathematical models for representing pesticide fate and transport to address water-quality issues. This discussion examines the role of models and how their use can provide a common thread to integrate the various discipline and agency contributions. The U.S. Environmental Protection Agency and State agencies use models to assist in complex regulatory decisions. Although USDA does not have a regulatory role, ARS is responsible for providing technology needed in selecting and/or designing on-farm practices that minimize adverse water-quality impacts and have developed the GLEAMS model for this purpose. GLEAMS can also be used to evaluate soil/pes- ticide groupings as to potential water-quality impacts; groupings which when translated to maps and geographic information systems (GIS) can provide regional problem perspectives. Just how pesticide use and root zone management will ultimately affect an aquifer system requires linked root/vadose/saturated zone models and the USDA, USGS, EPA, and the University of Georgia are conducting joint research near Plains, Georgia to develop and test such linked models.

\section{GEOCHEMISTRY OF GROUND WATER AT AND NEAR FERNLEY WILDLIFE MANAGEMENT AREA, LYON COUNTY, NEVADA}

\author{
Michael S. Lico \\ U.S. Geological Survey \\ Water Resources Division \\ Nevada District Office \\ Room 227, Federal Building \\ Carson City, Nevada 89701
}

The geochemistry of ground water in a shallow alluviallacustrine aquifer beneath the Fernley Wildlife Management Area and vicinity in northwestern Nevada was studied as part of the Department of the Interior irrigation-drainage program to determine sources of potentially toxic elements found in aquatic biota. The aquifer consists of unconsolidated silt and clay with some sand and gravel layers, and is composed of volcanic-lithic fragments (plagioclase, augite, and hypersthene in a felsitic groundmass), quartz, feldspars, micas, mafic minerals, and clay minerals. The ground water ranges from a dilute sodium-bicarbonate type water (dissolved solids, about 360 milligrams per liter) to a very saline sodium-chloride type (dissolved solids, about 16,000 milligrams per liter). The $\mathrm{pH}$ ranges from 7.5 to 8.7, and the Eh ranges from strongly oxidizing to slightly reducing.

A geochemical-reaction model was constructed from waterquality data, mineralogic data, and thermodynamic calculations. The model results indicate that the major-element aqueous chemistry is controlled by precipitationdissolution reactions, exchange processes, and evapotranspiration. Calcite and montmorillonite are precipitating and gypsum and volcanic-rock fragments (as seen visually) are dissolving withm the aquifer. Clay-mineral surfaces are adsorbing calcium and releasing sodium. The trace elements antimony, arsenic, boron, molybdenum, phosphorus, uranium, and vanadium probably are derived from dissolution of volcanic-rock fragments or surface coatings on aquifer material. Evapotranspiration concentrates the dissolved elements. These processes in combination account for the large increase in concentrations of dissolved solids and trace elements observed in the shallow ground water. 


\author{
Philip C. Loh*, Roger S. Fujioka and L. Stephen Lau \\ Department of Microbiology and \\ Water Resources Research Center \\ University of Hawaii \\ Honolulu, Hawaii 96822
}

The 1986 amendments to the Safe Drinking Water Act now includes viruses as a regulated contaminate. To implement this act, reliable, cost-effective and practical virus monitoring methods which can be performed by water utility laboratories must be developed. The nitrocellulose-enzyme immunoassay (NC-EIA) procedure and its streptavidin-biotin (SAB) amplification have been used in conjunction with the virusadsorption-elution methods employing electropositive microporous filters to regularly detect picogram to nanogram amounts of human enteroviruses such as poliovirus and hepatitis $A$ virus. If after initial recovery from water samples sufficient amounts of eluted virus are present, they could be successfully detected directly by the SAB/NC-EIA procedure without further reconcentration of the virus-containing eluates. Viral antigen in the same eluates was not detected by the non-ainplified NC-EIA procedure. The highest recoveries of eluted infectious virus were achieved with eluents containing small amounts of beef extracts $(0.30$ percent -1.0 percent). However, reconcentration of water eluates containing low levels of virus by organic floccula- tion resulted in interference with the NC-EIA procedure because of the excessive amounts of protein flocculates produced. In spite of this, the SAB/NC-EIA is a rapid, sensitive and specific alternate method to augment infectivity measurements in cell cultures currently employed by virus monitoring procedures. Also, the method may be used for the detection of difficult to grow and/or non-cultivatable enteroviruses which may be present in virus contaminated waters.

-Presenting author.

\title{
STATISTICAL APPLICATIONS USED IN THE US. GEOLOGICAL SURVEYS EVALUATION PROGRAM FOR STANDARD REFERENCE SAMPLES
}

\author{
H. Keith Long \\ U.S. Geological Survey \\ Water Resources Division \\ Bureau of Quality Assurance \\ Box 25045, Mail Stop 401 \\ Lakewood, Colorado 80225
}

The U.S. Geological Survey conducts a semi-annual interlaboratory testing program. A series of natural matrix water and sediment reference samples are prepared and distributed to all laboratories that provide waterquality analyses and data for use by the U.S. Geological Survey. Since 1962 , when the program began, the primary objectives have been:

(1) to provide carefully prepared, homogeneous, stable reference materials, and
(2) to evaluate the performance of the U.S. Geological Survey and other participating laboratories.

Analytical data collected by the evaluation program have been presented in a tabular format and evaluated using traditional statistical methods, since the program's inception. The occurrence of non-Gaussian distribution of analytical results, along with numerous outliers and analyses with less-than detection limit values, suggested a new presentation should be implemented. The new approach emphasizes the comparative analytical results rather than the mathematics, minimizes errors, and present informative graphic displays. Non-parametric statistical techniques are used to effectively display data without the need for rigorous mathematics and statistical knowledge by the reader.

The concepts of median (M) and hinges $(H)$, as used in nonparametric statistics, provide the 
tools for estimated data analysis. From the ordered range of data, the median (M) divides the range of data into two equal parts. These halves are similarly divided between the upper and lower extremes of the data set and the median. These mid-values are referred to as the upper and lower hinges ( $\mathrm{Hu}$ and $\mathrm{HI})$; the differences between $\mathrm{Hu}$ and $\mathrm{Hl}$ being the hinge spread (H-spr). From these values the most probable value, estimated standard deviation, and control limits are calculated for each constituent. "Ghosting" a box plot of $\mathrm{M}, \mathrm{Hu}$, and $\mathrm{Hl}$ values over a scattergram of the reported constituent values provides a visual presentation for readily discerning scatter, outliers, central tendency, bias, skewness, and method relationships.

\title{
OXIDATION OF AROMATIC CONTAMINANTS COUPLED TO MICROBIAL REDUCTION OF IRON
}

\author{
Derek R. Lovley, Debra J. Lonergan*, \\ Elizabeth J. P. Phillips, and Isabelle M. Cozzarelli \\ U.S. Geological Survey \\ Water Resources Division \\ 430 National Center \\ Reston, Virginia 22092
}

Previous geochemical studies have suggested that ferric iron may be an important oxidant for the removal of aromatic contaminants from anaerobic ground water. Studies in which carbon-14 tracers were injected into sediments collected from the U.S.G.S. Ground Water Toxics Study Site in Bemidji, Minnesota demonstrated that aromatic compounds could be oxidized to carbon dioxide in the iron-reducing zone. This oxidation was dependent upon microbial activity. Aromatic compounds commonly found as ground water contaminants did not chemically reduce ferric oxides at near neutral $\mathrm{pH}$. However, almost all of these compounds could be degraded by microorganisms using ferric iron as their terminal electron acceptor. Potential aromatic contaminants that could be oxidized by enrichment cultures of ironreducing organisms included: aromatic hydrocarbons, cresols, phenol, and aromatic acids. GS-15, an iron-reducing organism which we have previously isolated on acetate, was found to couple the complete oxidation of toluene, p-cresol, phenol, benzoic acid, or p-hydroxybenzoic acid to the reduction of iron. This is the first report of a microbial mechanism for the oxidation of aromatic compounds coupled to the reduction of iron and the first example of a pure culture of any kind which can anaerobically oxidize an aromatic hydrocarbon. Studies on the factors controlling the rate and extent of aromatic metabolism by GS-15 are expected to further understanding of aromatic metabolism in contaminated aquifers and to aid in the development of bioremediation strategies.

- Presenting author.

\section{MICROBIALLY CATALYZED REDUCTION OF IRON AND MANGANESE}

Derek R. Lovley* and Elizabeth J. P. Phillips

U.S. Geological Survey

Water Resources Division

430 National Center

Reston, Virginia 22092

The reduction of iron and manganese oxides has important direct and indirect impacts of water quality in many sedimentary environments. In previous geochemical studies, iron and manganese reduction have typically been modelled as nonen- zymatic reactions in which low redox potential and/or $\mathrm{pH}$ result in the reduction of iron through abiotic mechanisms. However, we have recently identified the first microorganisms know to enzymatically couple the complete oxidation of organic compounds to the reduction of iron or manganese. These dissimilatory iron-and manganese-reducing microorganisms can obtain energy for growth by oxidizing organic compounds to carbon dioxide with iron or manganese as the sole electron acceptor. They have been 
recovered from such diverse environments as the bottom sediments of fresh and brackish surface water environments as well as the sediments of a deep aquifer. Studies both with sediments and chemically defined culture media demonstrated that, with most organic compounds, iron is not reduced under sterile conditions but is rapidly reduced in the presence of the appropriate ironreducing organisms. The organisms appear to reduce the iron by a direct enzymatic mechanism. Iron reduction can not be attributed to microbial metabolism lowering the redox potential or $\mathrm{pH}$. These studies have provided the first mechanistic model for the coupling of organic matter oxidation to iron or manganese reduction in sedimentary environments.

* Presenting author.

\section{RETRIEVAL AND ANALYSIS OF THE RESULTS FROM THE BLIND SAMPLE QUALITY-ASSURANCE PROGRAM AT THE NATIONAL WATER QUALITY LABORATORY OF THE U.S. GEOLOGICAL SURVEY}

\author{
Keitlı J. Lucey \\ U.S. Geological Survey \\ Branch of Quality Assurance \\ P.O. Box 25046, MS 401 \\ Denver, Colorado 80225
}

The U.S. Geological Survey maintains a blind sample qualityassurance program based on the analysis of reference water samples by the National Water Quality Laboratory in Arvada, Colorado. Reference samples containing selected inorganic and nutrient constituents are disguised as environmental samples at the Survey's office in Ocala, Florida, and are sent periodically through other Survey offices to the laboratory. The results of this blind sample program indicate the quality of analytical data produced by the laboratory.
A menu-driven program to retrieve results of the blind sample program has recently been developed and is available to quality-assurance data users on the U.S. Geological Survey's national computer network. The blind sample database contains more than 40,000 determinations from the last 5 water years for 37 constituents at various concentrations, including dilute precipitation samples.

The data can be retrieved from the database for any user-defined time peried and for any or all available constituents. After the data user defines the retrieval, the program prepares statistical tables, control charts, and precision plots of the retrieved data and generates a report which is transferred to the user's office through the computer network.

This quality-assurance information will permit data users to document the quality of the analytical results received from the laboratory. The blind sample data is entered into the database within weeks after being produced by the laboratory and can be retrieved to meet the needs of specific projects or programs.

\section{RESULTS FOR MERCURY IN THE BLIND SAMPLE QUALITY-ASSURANCE PROGRAM OF THE U.S. GEOLOGICAL SURVEY}

\section{Keith J. Lucey* and David E. Erdınann \\ U.S. Geological Survey \\ Water Resources Division \\ Branch of Quality Assurance \\ Box 25046, MS 401 \\ Lakewood, Colorado 80225}

Since 1972 the U.S. Geological Survey has maintained a blind quality-assurance program based on the analysis of reference water samples by its water quality laboratories. For this program reference water samples are prepared from natural waters and standardized through an interlaboratory testing program. After the most probable values of the constituent concentrations have 
been determined, reference samples are disguised as normal environmental samples and periodically sent through other Survey offices to the laboratories. Results of this blind sample program indicate the quality of analytical data being produced by the laboratories.
Since October 1987 analytical results for mercury from the Survey's National Water Quality Laboratory show good agreement between values reported by the laboratory and the most probable value determined for the reference samples. Prior to this date, analytical results show a strong negative bias and lack of precision. Beginning October 1987 reference samples used in the blind sample program for mercury analysis were preserved with potassium dichromate. This change in preservation technique explains the change in analytical results.

"Presenting author.

\section{USE OF DEUTERIUM AND OXYGEN-18 TO TRACE THE INDUCED INFILTRATION OF DELAWARE RIVER WATER INTO THE POTOMAC-RARITAN-MAGOTHY AQUIFER SYSTEM, CAMDEN AREA, NEW JERSEY}

\author{
Steven D. McAuley* \\ U.S. Geological Survey \\ Hydrologic Simulation Program \\ Suite 206, 810 Bear Tavern Road \\ West Trenton, New Jersey 08628
}

\author{
Carol Kendall \\ U.S. Geological Survey \\ National Research Program-Geochemistry \\ Mail Stop 432, National Center \\ 12201 Sunrise Valley Drive \\ Reston, Virginia 22092
}

Ground-water withdrawals near Camden, New Jersey, have reversed the direction of ground-water flow and induced water from the Delaware River to enter the Potomac-RaritanMagothy aquifer system. The stable isotopes, deuterium and oxygen-18, were used to trace the movement of river water into the aquifer system. This method is possible because the isotopic composition of the Delaware River near Camden is isotopically depleted compared to local precipitation.
From 1983-1985, bimonthly samples were collected from the river and from lines of wells located parallel to the direction of regional ground-water flow. Isotopic composition of water from wells located within about 1 mile of the river indicate that river water constitutes more than 75 percent of the ground-water samples. Seasonal fluctuations in isotopic composition of ground-water from wells located within one-half mile of the river generally lag fluctuations in river-water composition by 2 to 10 months. Ground-water velocities, estimated on the basis of spatial variations in ground-water composition, average 15 feet per day.

Results of this study indicate that induced river recharge of the aquifer by river water may be traced by use of deuterium and oxygen-18 isotopes within about 1 mile of the Delaware River near Camden. The results of groundwater flow simulation in the area will be used to corroborate these findings.

*Presenting author.

\section{DISSOLVED OXYGEN TRENDS IN THE TRINITY RIVER, TEXAS}

\author{
Robert M. McCarthy* \\ Dallas Water Utilities \\ 1500 Marilla, Room 5AS \\ Dallas, Texas 75201
}

\author{
Richard Browning \\ Trinity River Authority \\ P.O. Box 60 \\ Arlington, Texas 76010
}

The Trinity, which flows through Dallas and Fort Worth, Texas is an effluent dominated stream. In dry weather, over 99 percent of its flow consists of wastewater effluent. A 1925 report described the Trinity as "some mythological river of death." Biweekly grab samples as recently as the early 1970's often showed dissolved oxygen levels at $0.0 \mathrm{mg} / \mathrm{L}$.

The Upper Trinity Water Quality Compact (Compact) was formed in
1975 to promote water quality in the Trimity River. The Compact consists of four major regional wastewater operators including the cities of Dallas and Fort Worth, the Trinity River Authority, and the 
North Texas Municipal Water District. Since 1977, the Compact has had annual cooperative agreements with USGS to operate a series of 4-parameter continuous autoinated water quality monitors in the Trinity. Compact members also began an aggressive program in the late 1970's to upgrade treatment processes and capacities to improve the quality of the Trinity.
Plots of data from the monitors located downstream of treatment plants show an increasing dissolved oxygen trend with averages increasing from about $2 \mathrm{mg} / \mathrm{L}$ in 1977 to $5-7 \mathrm{mg} / \mathrm{L}$ in 1988 , a period where effluent flows increased 60 percent! A control monitor, upstream of wastewater plants, exhibited no increased trend. DO levels at all monitors often fall below $1 \mathrm{mg} / \mathrm{L}$ after rain events which slightly elevate river flows. Additional study is ongoing to distinguish the roles of non-point runoff and bottom sediment resuspension in these DO depressions. However, these infrequent events have caused several fish kills and have become a timiting factor to the habitat in the Trinity River.

\title{
EFFECT OF INJURY INDUCED BY AQUATIC STRESS ON INDICATOR AND ENTERIC PATHOGENIC BACTERIA
}

\section{Gordon A. McFeters* and Ajaib Singh \\ Department of Microbiology \\ Montana State University \\ Bozeman, Montana 59717}

Indicator organisms and enteropathogenic bacteria become injured in aquatic environments because of exposure to sublethal levels of various physical and chemical stressors. The injured bacteria are unable to form colonies on commonly employed media containing some selective ingredients. This can lead to false estimation of bacteriological quality of water due to underestimation of indicator bacteria. The injury induced by two common aquatic stressors, i.e., chlorine and copper also causes partial loss of properties responsible for virulence of waterborne enteric pathogenic bacteria. However, the injured pathogens recovered in the mammalian gut after intraluminal inoculation and also in an in vitro system in the presence of suitable nutrients. After oral inoculation of enteropathogenic Escherichia coli, gastric acidity induced an additional stress in the culture but recovery of injury occurred after the pathogen reached the small intestine of the inoculated mice. However, some enteropathogens including strains of Salmonella typhimurium, Yersinia enterocolitica and Shigella species tested were less sensitive to injury from copper and chlorine than coliforms and are expected to survive longer in water. Thus in waterborne outbreaks it is important to detect and enumerate coliforms using a specifically developed medium (m-T7) and enteric pathogenic bacteria because of manifestation of virulence after recovery. These results prompted the development of a rapid detection method for injured and viable bacteria in aquatic environments by combining image analysis and the DVC method. This method provided quantitative data on viable (elongated) and injured cells.

*Presenting author.

\section{URANIUM-SERIES RADIONUCLIDES IN THE MISSISSIPPI RIVER}

\author{
Brent A. McKee \\ Louisiana Universities Marine Consortium (LUMCON) \\ Star Route Box 541 \\ Chauvin, Louisiana 70344
}

In conjunction with the USGS Mississippi River Project (R. H. Meade, coordinator), water samples were collected from the Mississippi River and major tributaries during different discharge stages over a two-year period. Radiochemical analyses reveal that "dissolved" ${ }^{238} U$ (the concentration that passes through a 0.4 micron filter) varies temporally by a factor of two. Variations in the colloidal uranium fraction accounts for most of the variability in "dissolved" ${ }^{238} \mathrm{U}$. The truly dissolved uranium fraction (less than 0.001 micron) remains relatively constant. Spatial trends in uranium concentrations throughout the Mississippi River system will be presented. 
Typical ${ }^{238} \mathrm{U}$ concentrations for the Mississippi River $(\sim 1.0 \mathrm{dpm} / \mathrm{l})$ are 50 times higher than values observed in the Amazon River. However, this difference can be attributed to differences in weathering regimes and natural environmental factors (which are determined largely by geologic setting). Based on ${ }^{234} U / /^{238} \mathrm{U}$ activity ratios, anthropogenic inputs of uranium (via phosphate fertilizers) do not appear to significantly affect the total uranium concentration of the Mississippi River.

Uranium-series isotopes of thorium, polonium and lead are particle-reactive and, therefore primarily associated with suspended particulates in the Mississippi River. Dissolved concentrations of these isotopes are very low in the river samples examined. However, the partitioning between dissolved and particulate phases exhibits some temporal variability for these isotopes. Possible factors controlling this variability will be discussed.

\title{
GROUNDWATER PROTECTION PROGRAMS IN ILLINOIS: APPLICATION OF GEOLOGIC MAPPING AND BASIC HYDROGEOLOGIC PRINCIPLES
}

\author{
Dennis P. McKenna*, Richard C. Berg, and John P. Kempton \\ Illinois State Geological Survey \\ Natural Resources Building \\ 615 East Peabody Drive \\ Champaign, Illinois 61820
}

Without a firm knowledge of the geologic framework and geologic controls on groundwater movement, occurrence, and availability, groundwater protection programs cannot be designed effectively. Misuse and misunderstanding of hydrogeologic terms and principles can also lead to misguided planning, monitoring, and regulation.

The Illinois approach to groundwater protection is (1) map the geology, (2) delineate aquifers, and (3) estimate the potential for aquifer contamination based on the hydrologic and geochemical properties of materials. Regional maps of the distribution of earth materials and a series of derivative contamination potential maps have allowed State and local agencies to more effectively focus efforts on water quality planning, monitoring, and regulation in the most vulnerable areas.

Regional geologic maps $(1: 250,000)$ have been used to $(1)$ screen areas for a low-level radioactive waste disposal facility, (2) assess the impact of proposed regulations on the future availability of municipal landfill sites, and (3) classify areas for a stratified random sampling of rural wells for contamination by agricultural chemicals. In combination with land use information, these maps will be used to identify priority groundwater protection planning regions and regulated recharge areas.

Large-scale hydrogeologic mapping is mandated by the Illinois Groundwater Protection Act as the basis for local governments to prohibit potential sources of contamination from locating in vulnerable areas. These maps will also be used in designing groundwater monitoring programs. County interpretive maps $(1: 62,500)$ have successfully been used to locate aquifers, site sanitary landfills, and restrict land uses in vulnerable areas.

*Presenting author. 


\section{PHYTOPLANKTON DYNAMICS IN ROCKY MOUNTAIN LAKES AND POTENTIAL RESPONSE TO CHANGES IN LAKEWATER CHEMISTRY}

\author{
Diane M. McKnight* and Richard Smith \\ U.S. Geological Survey \\ National Water Quality Laboratory \\ 5293 Ward Road \\ Mail Stop 408 \\ Arvada, Colorado 80002
}

\author{
J. Platt Bradbury \\ U.S. Geological Survey \\ Geologic Division \\ Denver Federal Center \\ Denver, Colorado 80225
}

Jill Baron and Sarah Spaulding
National Park Service
Water Resources Laboratory
105 Grasslands Laboratory
Colorado State University
Fort Collins, Colorado 80523

In a study of three lakes in Loch Vale, Rocky Mountain National Park, Colorado, phytoplankton dynamics were found to be controlled partially by the rapid flushing rate during snowmelt and the much slower flushing rate during late summer. During snowmelt, for example, the Asterionella formosa population in the most downstream lake has a rapid rate of increase as calculated from the flushing rate and the Asterionella formosa abundance in the inflow from the upstream lakes and in the lake itself. Measurement of photosynthetic rates indicated photoinhibition at the surface occurred only during the spring snowmelt and in a manner similar to that for temperate lakes at lower elevations. Because of their location on granitic terrain, these lakes may be influenced by acidic deposition and associated inputs of nitrate or sulfate in the future.
Measurements of changes in photosynthetic rate during shortterm exposure to acidic conditions indicated that the $A$. formosa population was not inhibited at $\mathrm{pH}$ values as low as 3.2 , but actually had an enhanced carbon-14 uptake, whereas the Oscillatoria limnetica population, which is dominant in the late summer and fall, was inhibited by low $\mathrm{pH}$.

*Presenting author.

\section{THE PRODUCTION AND CARBON ISOTOPIC COMPOSITION OF BACTERIAL $\mathrm{CO}_{2}$ IN DEEP COASTAL PLAIN SEDIMENTS OF SOUTH CAROLINA}

\author{
Peter B. McMahon* \\ U.S. Geological Survey \\ Water Resources Division \\ 1835 Assembly Street, Suite 677A \\ Columbia, South Carolina 29201
}

\author{
Douglas F. Williams \\ Department of Geological Sciences \\ University of South Carolina \\ Columbia, South Carolina 29208
}

\begin{abstract}
Measurements of the production and carbon isotopic composition of bacterial $\mathrm{CO}_{2}$ in cores of deep Coastal Plain sediments from South Carolina provide direct evidence linking bacterial $\mathrm{CO}_{2}$ to dissolved inorganic carbon in ground water. $\mathrm{CO}_{2}$ production rates ranged from 0 to 2,750 nanomoles of $\mathrm{CO}_{2}$ per gram of sediment per day in samples amended with oxygen, nitrate, and sulfate as sole electron acceptors. Measured $\mathrm{CO}_{2}$ production rates were at least five orders of

magnitude greater than rates calculated from geochemical models of the Coastal Plain aquifers. This indicates that the bacterial $\mathrm{CO}_{2}$ production potential in these sediments is sufficient to account for observed increases in dissolved inorganic carbon in the ground water.

The carbon isotopic composition of bacterial $\mathrm{CO}_{2}$ ranged from -29.7 to -18.0 permil and appears to be controlled by: (1) the isotopic composition of the bulk sedimentary organic matter from
\end{abstract}

which the $\mathrm{CO}_{2}$ is derived, and (2) the isotopic composition of specific components of the organic matter which are preferentially degraded by bacteria. The measured isotopic compositions of bacterial $\mathrm{CO}_{2}$ agree with compositions predicted from geochemical models of the Coastal Plain aquifers, thereby providing direct evidence linking bacterial $\mathrm{CO}_{2}$ to dissolved inorganic carbon in the ground water.

*Presenting author. 


\title{
THE EFFECTS OF FRESHWATER INFLOW ON THE PHYTOPLANKTON CARBON-14 PRODUCTIVTTY AND CHLOROPHYLL-A IN THE CHARLOTTE HARBOR ESTUARINE SYSTEM, SOUTHWESTERN FLORIDA
}

\author{
Benjamin F. McPherson* \\ U.S. Geological Survey \\ 4710 Eisenhower Blvd., B-5 \\ Tampa, Florida 33634
}

\author{
Ralph T. Montgomery \\ Environmental Quality Laboratory, Inc. \\ 1009 Tamiami Trail \\ Port Charlotte, Florida 33952
}

Phytoplankton carbon-14 productivity and chlorophyll-a concentrations were measured every other month from November 1985 through September 1986 at 12 stations in the Charlotte Harbor estuarine system. Average monthly productivity ranged from $19 \mathrm{mg} / \mathrm{m}^{3} / \mathrm{hr}$ (milligrams per cubic meter per hour) in January to $101 \mathrm{mg} / \mathrm{m}^{3} / \mathrm{hr}$ in September. Average monthly chlorophyll-a concentrations ranged from 3.3 $\mathrm{mg} / \mathrm{m}^{3}$ (milligrams per cubic meter) in January to $13.1 \mathrm{mg} / \mathrm{m}^{3}$ in July. The high values in July and September coincided with maximum water temperatures and maximum freshwater inflow and nutrient loading to the estuary. The freshwater inflow affects estuarine phytoplankton by lowering salinity, increasing nutrient availability, and reducing light penetration in the water column. Inorganic nitrogen is probably the most important macronutrient in limiting phytoplankton productivity. Concentrations of inorganic nitrogen are often at or below the detection limit throughout most of the high salinity [greater than 20 o/oo (parts per thousand)] regions of the estuary, and the nitrogen needs of the phytoplankton are met largely by recycling and regeneration within the estuary. During summer, high nutrient loading increases nitrogen availability in the low salinity (less than $10 \%$ ) regions of the estuary, but because the freshwater inflow is highly colored (often greater than 200 platinum-cobalt units) during this season, the availability of light in the water column is greatly reduced and may limit phytoplankton productivity in these low salinity regions. The color in the freshwater inflow is sufficiently diluted by seawater at midsalinity regions so that the availability of light increases and the inorganic nitrogen stimulates phytoplankton productivity and growth.

"Presenting author.

\section{SAMPLING STRATEGIES AND PROCEDURES FOR TRACKING TOXIC CHEMICALS THROUGH LARGE RIVER SYSTEMS SUCH AS THE MISSISSIPPI RIVER}

\author{
Robert H. Meade \\ U.S. Geological Survey \\ Water Resources Division \\ Branch of Regional Research, Central Région \\ MS 413, Box 25046 \\ Lakewood, Colorado 80225
}

A Lagrangian strategy for sampling large rivers, which was developed and tested in the Orinoco and Amazon Rivers of South America during the early 1980 s, is now being applied to the study of toxic chemicals in the Mississippi River. A series of 15-20 cross sections of the Mississippi mainstem and its principal tributaries is sampled by boat in downstream sequence, beginning upriver of St. Louis and concluding downriver of New Orleans 3 weeks later. The timing of the downstream sampling sequence approximates the travel time of the river water. Samples at each cross section are discharge-weighted to provide concentrations of dissolved and suspended constituents that are converted to fluxes. Water-sediment mixtures are collected from 10-40 equally spaced points across the river width by sequential depth integration at a uniform vertical transit rate. Essential equipment includes (1) a hydraulic winch, for sensitive control of vertical transit rates, and (2) a collapsible-bag sampler, which allows integrated samples to be collected at all depths in the river. A section usually is sampled in 4-8 hours, for a total saniple recovery of 100 $120 \mathrm{~L}$. Sampled concentrations of suspended silt and clay, and presumably those of adsorbed toxic chemicals, are reproducible within 3 percent. 


\title{
USE OF DNA (DEOXYRIBONUCLEIC ACID) AND TANC (TOTAL ADENYLATE NUCLEOTIDE CONTENT) MEASUREMENTS FOR DELINEATING MICROBIAL ACTIVITY AND ESTIMATION OF BIOMASS IN AN ORGANICALLY CONTAMINATED AQUIFER
}

\author{
David W. Metge* and Ronald W. Harvey \\ U.S. Geological Survey \\ Water Resources Division \\ 345 Middlefield Road \\ Menlo Park, California 94025
}

\author{
Myron H. Brooks and Richard L. Smith \\ U.S. Geological Survey \\ National Water Quality Laboratory \\ 5293 Ward Road \\ Arvada, Colorado 80002
}

Methods were modified and developed to estimate DNA and TANC concentrations, distributions and partitioning in a contaminated, carbon-limited sandy aquifer. The usefulness of these biological parameters for estimating biomass was investigated. DNA was found to correlate well with bacterial cell numbers and generally decreased with distance from the contamination source. Several pools of DNA were delineated, including bacterial, protozoan, and adsorbed fractions. Bacterial cell DNA content varied from 3.4 fg (femtograms) in uncontaminated nutrient-poor regions of this aquifer, to $27.1 \mathrm{fg}$ per cell in bacterial populations from more contaminated regions. DNA per cell and DNA pool differences were found to be dependent upon location, nutrient conditions and consequential decreases in bacterial abundance. TANC estimates decreased from $111 \mathrm{pM}$ (picomoles per liter) near the contaminant source to $22 \mathrm{pM}$ at a distance of 3.3 kilometers from the contaminant source. TANC correlated well with bacterial cell numbers. Adenylate energy charge values were relatively uniform and low throughout the length of the contaminant plume, suggesting that microbial communities within the contaminant plume were in a state of metabolic stress. Addition of glucose increased community energy charge values from 0.6 to 0.73 during the course of a 48 hour incubation.

*Presenting author.

\section{CONCENTRATING SUSPENDED SEDIMENT FOR ORGANIC ANALYSIS}

\author{
Michael Meyer*, E.M. Thurman, Robert Bannister \\ U.S. Geological Survey \\ Organic Geochemistry Laboratory \\ 4821 Quail Crest Place \\ Lawrence, Kansas 66049
}

Analyzing organic compounds on sediments is difficult because of the problems associated with concentrating the sediment in enough quanitity for analysis and extracting the organic compounds from the sediment sample for analysis. Three devices that separate and concentrate sediment from native water were evaluated; two flow-through centrifuges (Westfalia, Alfa Laval), and one tangential-flow filtration device (Pellicon). These devices were tested for possible contribution of organic compounds, sample concentration (recovery), and crosscontamination. Experimental results show that all three devices contribute plasticizers (phthalate esters) as a major contaminant. However, most of these problems can be avoided by replacing rubber and plastic tubing with Teflon tubing and metal fittings. No statistical difference was detected between the three devices in concentrating sediment as measured by weight of sample recoveries.
Experiments with water-soluble herbicides showed no detectable cross-contamination between samples. Simple solid-phase extraction followed by gas chromatography-mass spectrometry analysis using "selected ion monitoring" makes analysis of herbicides on suspended sediment a relatively rapid and easy procedure. Future work will test these three devices with less water-soluble compounds.

*Presenting author. 


\author{
C. T. Miller* and J. A. Pedit \\ Department of Environmental Sciences and Engineering \\ The University of North Carolina \\ 105 Rosenau Hall \\ Chapel Hill, North Carolina 27599-7400
}

The sorption-desportion process is one of the most important processes governing the fate and movement of hydrophobic organic solutes in subsurface environments. The objectives of the research currently underway are: to investigate the importance of sorption to low carbon materials; to evaluate the effect of multiple solutes on the rate and equilibria of the sorption-desorption process; and to evaluate numerical models for the purpose of predicting laboratory experimental results and evaluating hypothetical fieldscale transport.

A series of laboratory bottle-point and column experiments are reported for a matrix of four solutes (diuron, 1,2,4trichlorobenzene, biphenyl, lindane) and two subsurface materials. The bottle-point results show that several weeks are required to approach an eventual nonlinear equilibrium. Columnreactor experiments were performed to observe the effect of pore velocity, influent concentration, and duration of solute pulse on the nature of the desorption elution response. The results of colunin experiments show a long tail on the elution phase of the experiment, which is consistent with a modeling analysis based upon nonlinear and hysteresic desorption equilibrium. Extension of these findings to a hypothetical field-scale system shows that nonlinear desorption and hysteresic equilibrium is an important factor affecting aquifer cleanup times.

*Presenting author.

\title{
LOW-LEVEL NUTRIENT ANALYSIS OF NATURAL-WATER SAMPLES USING A RAPID-FLOW ANALYZER
}

\author{
Donna L. Milne*, Merle Shockey, Tom Bushly, \\ and Carl Harris \\ U.S. Geological Survey \\ National Water Quality Laboratory \\ Low Ionic Strength Section \\ 5293-B Ward Road \\ Arvada, Colorado 80002
}

The U.S. Geological Survey National Water Quality Laboratory analyzes a large number of natural water samples for low level nutrients. Many of the samples have concentration levels in the microgram-per-liter range, and therefore require analytical methods capable of detecting the analyte in this range. Traditional colorimetric methods for low level analyses are slow and result in shifting baselines, making interpretation difficult. Use of a rapid-flow colorimetric analyzer has increased the rate of analysis from 30 to 70 samples per hour. This increase significantly reduces the length of an analytical run and decreases the need for long-term instrument stability. The signal-tonoise ratio has been enhanced by the use of fiber optics and an electronic bubble gate. This enhanced ratio results in improved precision and better detection limits. At the low end of the range the rapid-flow analyzer has improved precision over the traditional method by 866 percent for phosphate, 367 percent for nitrite, 150 percent for ammonium, and 36 percent for nitrite plus nitrate. A detection limit of 1 microgram-per-liter has been achieved for nitrite and phosphate, 2 microgram-per-liter for ammonium, and 5 microgram-perliter for nitrite plus nitrate.

*Presenting author. 


\section{DISCHARGE-WEIGHTED PUMPING METHOD FOR COLLECTING THE FINE FRACTION OF SUSPENDED SEDIMENT}

\author{
John A. Moody \\ U.S. Geological Survey \\ MS 413, Box 25046 \\ Denver, Colorado 80225
}

Collecting discharge-weighted suspended-sediment samples from heterogeneous rivers by using the depth-integration method is limited by the volume of water and, therefore, the mass of suspended sediment that can be collected. A pumping method has been developed for collecting the fine fraction, that increases the volume of sample collected, yields a discharge-weighted sample, and does not require a time-consuming measurement of discharge to determine the cross-channel distribution of discharge.

The pumping system consists of a 12.0 millimeter outside diameter, Teflon tube inside a 12.7 millimeter inside diameter, double-braided stainless-steel sleeve attached to a Columbus-type sounding weight.
The tubing is lowered from a large boat to a depth of 5 meters or onehalf the water depth (whichever is smaller) and 500-700 liters of water is pumped up through the tube by a double-diaphragm Teflon pump that is driven by compressed air. The boat holds position at $20-40$ equally spaced stations or verticals across the river; at each vertical, a volume of water is pumped that is proportional to the fraction of the total water discharge at that vertical.

If a logarithmic velocity profile is assumed for a depth $d_{i}$, then the discharge per unit width, $q_{i}$, is given by $\mathrm{cid}_{\mathrm{i}}^{\mathrm{S} / 3}$ and the dischargeweighted volume to be pumped at each vertical $i$ is proportional to $\mathrm{q}_{\mathrm{i}} / \sum \mathrm{q}_{\mathrm{i}}$. Initial evaluation indicated that, as a first approximation, $c_{i}$ can be considered a constant across 95 percent of the river channel. Measurements in the Mississippi River indicated that $c_{i}$ changes near the river banks, and additional measurements are being made to determine an empirical relation between $\mathrm{c}_{\mathrm{i}}$ and the distance from the bank. Additional changes in $\mathrm{c}_{\mathrm{i}}$ across the channel can be estimated in the field by measuring the velocity at a few verticals prior to pumping.

Questions that are being evaluated are: (1) For what size classes does this method obtain a representative sample? (2) Does the method produce a representative chemical sample? and if so, for what substances?

\section{ACCUMULATION OF ORGANOCHLORINE PESTICIDE AND PCB RESIDUES IN THE SEDIMENTS OF ICEDALE LAKE, CHESTER COUNTY, PENNSYLVANIA}

Sediments of Icedale Lake were cored and analyzed for residues of organochlorine pesticides and polychlorinated biphenyls (PCB's). The lake, located in southeastern Pennsylvania, has a drainage area of approximately 20 square miles. Land use in the basin is largely agricultural. The lake was created by a dam in 1913 for the production of ice and has been dry since 1984 when the dam was intentionally breached.
Craig R. Moore* and James R. Kolva

U.S. Geological Survey, WRD 111 Great Valley Parkway

Malvern, Pennsylvania 19355

Radionuclide analyses of lead-210 and cesium-137 activities were used to date the lake sediments and aid in determination of the average sedimentation rate, which was 0.71 centimeters per year during 1913-84. The sediment cores were divided into 2 centimeter-long sections, each representing a 3-year timespan and analyzed for organochlorine pesticide and PCB concentrations.
Concentration profiles are being developed for 1940-84 and compared to production and sales figures for the compounds in the United States over the same time period. The concentrations found in the sediment cores, for different time periods, also are being compared to concentrations found in stream-bottom material sampled at 42 sites in Chester County in 1985-86.

- Presenting author. 


\title{
EFFECTIVENESS OF AQUIFERS IN THE DILUTION OF NONPOINT SOURCE LOW MCL CONTAMINANTS
}

\author{
W. Bruce Moore* and Honesto Roaza \\ Northwest Florida Water Management District \\ Route 1, Box 3100 \\ Havana, Florida 32333
}

\begin{abstract}
Agricultural pesticides can be an extensive source of nonpoint pollution to surface and ground water. Many of these agricultural pollutants have extremely low maximum contaminant levels (MCL) due to their suspected toxicity. These low MCL's are significant in light of the volume of water that is required to avoid such concentrations in hydrogeological systems. Our conceptual treatment of an agricultural pollution problem is illustrated by the karstic Floridan aquifer beneath Jackson County, Florida in a study area of approximately 825 square kilometers which has been

contaminated with the nematicide ethylene dibromide (EDB). We estimate that over $8200 \mathrm{~kg}$ of EDB were applied annually for over twenty years. Of the 3000 Floridan wells sampled within a six year monitoring period, EDB was detected in over 50 wells in concentrations at or greater than the current MCL $(0.02 \mu \mathrm{g} / \mathrm{L})$. Because the exact amount of EDB released into the aquifer or held in subsurface storage is not known, a series of hypothetical scenarios that incorporate known aquifer parameters and estimates of unknown aspects of the problem (mass of EDB applied/-
\end{abstract}

released/stored, etc.) are considered. Our results show that the entire volume of water in the aquifer could be contaminated to the MCL by 25 to $200 \mathrm{~kg}$ of EDB. These preliminary results indicate the inability of the aquifer to disperse and dilute even relatively small amounts of EDB. Because the amount of contaminant potentially available for release in the study area is many times greater than the amount needed to contaminate the aquifer, dilution may not readily resolve the problem.

*Presenting author.

\section{THE CAPACITY OF A BOTTOMLAND-HARDWOOD WETLAND TO MODIFY THE CHEMICAL AND SEDIMENT COMPOSITION OF AN ADJACENT RIVERINE SYSTEM}

\author{
E. E. Morris* \\ U.S. Geological Survey \\ Water Resources Division \\ 2301 Federal Office Building \\ Little Rock, Arkansas 72201
}

\author{
Barbara A. Kleiss \\ Waterways Experiment Station \\ U.S. Army Corps of Engineers \\ P.O. Box 631 \\ Vicksburg, Mississippi 39181
}

\section{Dr. Joseph F. Nix \\ Ouachita Baptist University \\ P.O. Box 3780 \\ Arkadelphia, Arkansas 71923}

selected chemical constituents into and out of a bottomland-hardwood area are being determined at a study site along the Cache River in eastern Arkansas. Results of this loading study can lead to information on the ability of the wetland system to retain or export various chemical constituents.

The drainage area of the site is 135 square miles with another 1,037 square miles of contributing area upstream of the site. Much of the drainage area has undergone extensive channelization, particularly during the 1960's to allow agricultural development of the basin. Agricultural runoff in the basin has resulted in increased turbidity and suspended sediment and nutrient loads in the Cache River. 
Several tasks have been undertaken in order to determine chemical loading rates through the study area. Hydrologic gaging stations have been established at inflow and outflow points on the Cache River and at four tributary sites. Concentrations of 25 chemical constituents have been measured biweekly at these sites since June 1987. In addition, total phosphorus, total Kjeldahl nitrogen, and suspended sediment concentrations have been measured daily, while $\mathrm{pH}$, specific conduc- tance, and dissolved oxygen have been measured continuously.

Initial results of the loading study indicate that the bottomlandhardwood-wetland system acts to reduce suspended sediment and total nitrate loads by 19 and 29 percent, respectively, while total phosphorus and total organic carbon loads are increased by 23 and 27 percent, respectively, over the annual hydrologic cycle. However, different trends emerge when the loading information is stratified into hydrologic stages. Every con- stituent considered is exported during low water when there is limited contact between the river and wetland, but every constituent is retained at the stage where the cypress-tupelo part of the flood plain is inundated. This indicates that in bottomland-hardwood systems, import-export cycles are closely related to hydrology, whereas in other wetland types the cycles are closely related to vegetative growing season.

*Presenting author.

\section{TOXICITY OF SEDIMENTS, EFFLUENTS AND RECEIVING WATERS OF THE LOWER CALCASIEU RIVER, LOUISIANA}

\author{
George Morrison* \\ U.S. Environmental Protection Agency \\ Environmental Research Laboratory \\ South Ferry Road \\ Narragansett, Rhode Island 02882
}

\author{
Elise Torello and Michele Redmond \\ SAIC \\ c/o U.S. Environmental Protection Agency \\ Environmental Research Laboratory \\ South Ferry Road \\ Narragansett, Rhode Island 02882
}

The toxicity to marine organisms of sediments, effluents, and receiving waters of the lower Calcasieu River and two tributaries was determined. Toxicity tests for effluents and receiving waters consisted of: (1) macroalga Champia parvula seven day reproductive test, (2) sea urchin Arbacia punctulata two hour reproductive test, (3) mysid Mysidopsis bahia seven day reproductive, growth, and survival test, and (4) inland silverside Menidia beryllina seven day larval fish growth and survival test. Sediment toxicity was evaluated with the amphipod Ampelisca abdita ten day survival test. Toxicity was evident in six of eight effluents, 20 of 23 receiving waters, and 21 of 35 sediment samples. Distribution and extent of sediment and receiving water toxicity was generally, but not always, associated with locations of toxic effluent discharges.

*Presenting author.

NATIONAL WATER CLEANUP UNDER THE CLEAN WATER ACT 1976-89

\author{
Charles D. Mosher \\ U.S. General Accounting Office \\ Room 1992, Jackson Federal Building \\ 915 Second Avenue \\ Seattle, Washington 98174
}

This paper provides a history of U.S. General Accounting Office observations about the Environmental Protection Agency's (EPA) implementation of the Clean Water Act (Act), with a special emphasis on the continuing need for good water quality data. This data is needed for evaluating program effectiveness, providing alternative cleanup approaches, and directing program adjustments and changes. Billions of Federal, State, local, and private dollars have been spent on treatment plans and other facilities to restore and maintain the quality of our nation's waters. While progress has been made, some waters are still polluted and more needs to be done to clean them up. The Act has only been partially implemented. The historical emphasis on point source cleanup under the Act needs to be augmented with better water assessments and more emphasis on nonpoint source cleanup. Section 
303(d) of the Act provides for this, but this section has been considered a low priority by the EPA. Implementation of this section could help communities identify cleanup approaches that are both more cost efficient and environmentally effective. The success of this effort requires more, not less, water data collection and analysis. Better data is needed to better identify nonpoint pollution causes and the most effective mix of point source and nonpoint source cleanup actions. Special U.S. Geological Survey water studies and assessments can help provide the needed data.

\section{OCCURRENCE AND VARIABILITY OF ESCHERICHIA COUI AND FECAL-COLIFORM DENSITIES IN THE OLENTANGY AND SCIOTO RIVERS IN THE COLUMBUS, OHIO, AREA}

\author{
Donna N. Myers \\ U.S. Geological Survey \\ 975 West Third Avenue \\ Columbus, Ohio 43212-3192
}

Segments of the Scioto and Olentangy Rivers flow through highly urbanized areas and are used for boating, water-skiing, and wading. The suitability for bodycontact recreation of selected segments of the Scioto and Olentangy Rivers was investigated by use of the fecal-coliform and E. coli (Escherichia coli) tests. Two upstream and one downstream site that bracketed the recreational segnient were sampled five times monthly during the recreational seasons of 1987 through 1989. Ohio's fecal-coliform Water Quality Standards and Federal E. coli criteria were used to evaluate these sites on the basis of monthly geometric mean bacterial densities. Additional sampling was conducted during three rainfall events, and at 24-hour increments afterward, to determine whether runoff events resulted in elevated bacterial densities. Seven other sites that bracket the recreational segment were sampled monthly to characterize base-flow bacteriological and chemical conditions.

Geometric mean fecal-coliform and $E$. coli densities were variable and ranged from less than 100 to more than 75,000 per 100 milliliters during base-flow conditions.
Bacteriological densities were elevated to 2,000 to 3,000 per 100 milliliters as long as 3 days after rainfall events. Samples collected from storm sewers discharging to the Scioto River contained bacterial densities higher than that of the receiving water. Four of seven monthly sites had samples that exceeded Ohio's fecal-coliform standards and Federal E. coli criteria during base-flow conditions. Storm sewers, other sanitary-waste sources, and flow conditions may have contributed to the variability of bacterial densities in the study area.

\section{GLACIAL-ICE GEOCHEMISTRY, KNIFE POINT GLACIER, WIND RIVER RANGE, WYOMING-RECONNAISSANCE-PHASE RESULTS}

\author{
David L. Naftz* \\ U.S. Geological Survey \\ 2617 E. Lincolnway, Suite B \\ Cheyenne, Wyoming 82001 \\ James A. Rice \\ Department of Chemistry \\ South Dakota State University \\ Brookings, South Dakota 50006
}

\author{
Howard E. Taylor \\ U.S. Geological Survey \\ 5293 Ward Road \\ Arvada, Colorado 80002 \\ James R. Ranville \\ U.S. Geological Survey \\ Mail Stop 424 \\ Denver Federal Center \\ Lakewood, Colorado 80225
}

A record of atmospheric deposition is preserved in the ice in alpine glaciers in the Wind River Range of Wyoming. During a reconnaissance-phase study conducted in 1988, ice samples were collected from a trench in Knife Point Glacier. The objective was to determine if concentrations of selected chemical constituents in ice samples from temperate glaciers can be used to reconstruct 
the annual-weighted quality of atmospheric deposition.

Ice stratigraphy, used in conjunction with large concentrations of trichlorofluoromethane (23.1 to 177 micrograms per liter) in the ice, identified eight annual ice layers corresponding to years 1980-87. Preliminary identification of a Mount St. Helens ash horizon at 7.4 feet below the glacier surface was used as a stratigraphic time line to date ice layers.

Preliminary chemical results indicated statistically significant (0.01 confidence level) positive correlation of dissolved-chloride and -sulfate concentrations determined from composite samples of annual ice layers to annual-weighted, dissolvedchloride and dissolved-sulfate concentrations measured in wet deposition at the National Atmospheric Deposition Program (NADP) site near Pinedale, Wyoming from $1982-87$ (0.98 for chloride and 0.95 for sulfate). The following regression equation was developed for dissolved sulfate:

SO4.PPT $=0.883\left[\mathrm{SO}_{4} . \mathrm{ICE}\right]+0.573(1)$

where

$\mathrm{SO}_{4} . \mathrm{PPT}$ is annual-weighted, dissolved-sulfate concentration in wet deposition (NADP site near
Pinedale, Wyoming) in milligrams per liter; and

$\mathrm{SO}_{4}$.ICE is dissolved-sulfate concentration in ice from Knife Point glacier composited for a corresponding annual layer.

Dissolved concentrations of sulfate and other chemical constituents in deeper annual ice layers (pre-1982) will be determined in future research to provide estimates of long-term trends in the quality of wet deposition and data on past climatic cycles.

*Presenting author.

\section{COMPARATIVE BIOCONCENTRATION OF SELENATE AND SELENITE BY BLUEGILL (LEPOMIS MACROCHIRUS) AND FATHEAD MINNOWS (PIMEPHALES PROMELAS)}

\section{Richard S. Ogle* and Allen W. Knight \\ Dept. Land, Air, and Water Resources \\ University of California \\ Davis, California 95616}

Selenium contamination of aquatic ecosystems is a problem of increasing concern in many areas of the U.S. Several field and laboratory studies have demonstrated that bioaccumulation of selenium by fish can result in reproductive impairment, and ultimately to population extinctions. However, previous studies in our laboratory have suggested that there may be very significant differences in the way different fish groups (e.g. minnows vs. sunfish) bioaccumulate selenium. With this in mind, we are conducting an investigation into the roles of bioconcentration and biomagnification in the comparative bioaccumulation of selenate and selenite by bluegill and fathead minnows, and report here the results of the bioconcentration phase of our research. Four 28-day experiments were conducted in which each fish species was exposed to either selenate or selenite at selenium levels of 0 (control), 5, 10 and 50 $\mu \mathrm{g} /$. Fish were sampled at $7,14,21$, and 28 days and analyzed for whole body selenium levels. Bluegill bioconcentrated selenite to greater body burden selenium than did the fathead minnow. Surprisingly, fathead minnows did not bioconcentrate either selenate or selenite to selenium levels greater than those observed in control fish. While we had originally hypothesized that it was differences in biomagnification that would explain the reported selenium accumulation differences between these species, the results of this study demonstrate that differences in bioconcentration potential also play a role.

* Presenting author. 


\section{A RAPID SCREENING METHOD FOR ESTIMATING ATRAZINE AND ITS METABOLITES IN NATURAL WATER SAMPLES}

\author{
M. G. Ondrus \\ Department of Chemistry \\ University of Wisconsin-Stout \\ Menomonie, Wisconsin 54751
}

\author{
T. R. Steinheimer* \\ National Water Quality Laboratory \\ 5293 Ward Road \\ Arvada, Colorado 80002
}

\begin{abstract}
A screening method for quantitative estimation of atrazine, desalkylatrazines, and hydroxyatrazine in natural water samples has been developed. These analytes are removed from water by passing the sample through a sorbent matrix of reversed-phase silica packing which has been chemically modified to incorporate cyclohexyl groups at the surface. Cyclohexyl extraction cartridges provide the greatest efficiency for retention of atrazine metabolites commonly found in natural water samples. High-performance liquid chromatography, employing a
\end{abstract}

methanol-water gradient, is used to separate the analytes of interest. These compounds are detected photometrically using filter photometers with a photo-diode array system. Identification of analytes is done by retention time and absorption spectra matching against reference standards. Terbuthylazine is used for internal standard quantitation.

Method validation involves determination of percentage of recovery for all analytes from natural water samples fortified with a standard mixture prior to extraction. Test matrices chosen for this evaluation included laboratory distilled water, Mississippi River water (from a dam near Winona, Minnesota), and ground water from a shallow aquifer near Rusk, Wisconsin (in an area of known atrazine contamination). Spiking levels ranged from 0.2 to 20 micrograms per liter for all determinations, which were run in quadruplicate. Nominal limit of detection, based upon a 0.5-liter test sample is approximately 1.0 microgram per liter.

*Presenting author.

\section{IS WATER A RELEVANT SAMPLING MEDIUM FOR TOXIC CHEMICALS? AN ALTERNATIVE ENVIRONMENTAL SENSING STRATEGY}

Aquatic toxic chemical monitoring and assessment conventionally focuses upon a menu (list) of target compounds which are usually sampled from small whole water samples. One example is the US-EPA Priority Pollutants menu consisting of 129 substances. Using a long and relatively unimpacted prairie river we evaluated the presence and ecotoxicological response of chemistry associated with whole water and with suspended and bottom sediments. Our water samples were either eight or sixteen liters; suspended sediment was
Edwin D. Ongley*, D. A. Birkholz J. H. Carey, and M. R. Samoiloff National Water Research Institute Canada Centre for Inland Waters Box 5050, Burlington Ontario L7R 4A6

collected by continuous-flow centrifugation. Water samples were extracted for acid and neutral compounds; sediment samples were extracted for acid compounds and four base/neutral fractions. Part of the eluant for each fraction was exchanged into DMSO for subsequent bioassay using a nonstandard Ames test and the Panagrellus redivinus nematode bioassay. We found: (1) significant toxicity in the absence of listed priority pollutants, (2) nil ecotoxic effects in the presence of priority pollutants, (3) largest toxic response and largest number of priority chemicals associated with the suspended sediment phase, and (4) little comparison between toxic response of whole water samples relative to sediment contained in those aqueous samples. We conclude that conventional, small volume sampling of whole water is quite inadequate for toxic chemical monitoring, and that the menu approach is inefficient and ineffective. We suggest a coupled chemical-bioassay approach to enhance the efficiency and information content of ambient water-quality programs.

*Presenting author. 


\title{
DEVELOPMENT AND EVALUATION OF AN APPROACH INTEGRATING AN OPTIMIZATION MODEL AND AN EXPERT SYSTEM FOR IDENTIFYING UNKNOWN GROUNDWATER POLLUTION SOURCES
}

\author{
Gerald T. Orlob*, M. Levent Kavvas, Jean E. Beegle, and Bithm Datta \\ Department of Civil Engineering \\ University of California \\ Davis, California 95616
}

It is difficult to identify unknown sources of groundwater contamination using limited amounts of quality monitoring data. These difficulties can be attributed to the multiplicity of potential contamination sources of unknown strength, origin, and chemicalbiological makeup; our inability to model accurately the nonuniform, heterogeneous characteristics of the porous media; uncertainties in the estimation of hydrologic parameters, and errors in the field or laboratory measurements of groundwater quality characteristics. A new approach to the solution of this problem is presented, that utilizes i) an optimization model for initial screening of potential contamina- tion sources, and ii) an Expert System (ES) embedding a pattern recognition technique to identify magnitudes and locations of unknown sources.

The optimization model is necessary as a screening model for reducing the dimensionality of the search for potential location and magnitude of the pollution sources in the pattern recognition function of the ES. Extensive evaluation of this model's performance, and the sensitivity of the numerically simulated pollutant plumes to the unmodeled uncertainties, spatial heterogeneities in the aquifer parameters, and measurement or estimation errors, are presented. These sensitivity analyses are essential also for developing the pattern recognition algorithm, and specifying heuristic rules for the ES.

The pattern recognition algorithm embedded in the ES is used for making statistical inferences about the locations and magnitudes of pollutant sources. These inferences are based on matching of discretized numerical feature measurements (of concentration at measurement sites) with the features obtained from simulation of concentrations for various combinations of potential locations and magnitudes of entering pollutants. The matching process is accomplished by a finite sequential pattern recognition technique. Performance of the ES is also evaluated.

*Presenting author.

\section{THE TRINITY RIVER, TEXAS: A CASE STUDY OF THE LIMITS OF WASTE-LOAD ALLOCATION}

\author{
James Patek* \\ Jones and Neuse, Inc. \\ 2720 Bee Cave Road \\ Austin, Texas 78746
}

\author{
George Ward \\ University of Texas at Austin \\ Austin, Texas 78712
}

\author{
Robert McCarthy \\ Dallas Water Utilities \\ 1500 Marilla, Room 5AS \\ Dallas, Texas 75201
}

The Trinity River flows through the Dallas-Fort Worth metroplex and the agricultural area downstream. The river is dominated by surface run-off. The semiarid North Texas climate changes from seasons of intense convective precipitation to virtual drought, with the result that river flows range over four orders of magnitude. The river in the metroplex has been channelized and leveed for flood protection and receives copious volumes of urban run-off. It also receives wastewater discharges, and low flow over 99 percent of the river flow is treated effluent. This paper reviews water quality problems in the Trinity and the need for employing mathematical models in relating response of the river quality to external controls. Results of numerical modeling the river and verification 
against field data are presented, and the use of the model in a succession of waste load evaluations (WLEs) is described. These WLEs have dictated advances in waste treatment to the point that the low-flow regime exhibits good, even excellent, water quality. Yet the Trinity continues to be plagued with critical situations and extensive fish kills. Implications are discussed on the relative merits of point-source controls when other factors are dominant, and the difficulties of setting valid waterquality standards.

*Presenting author.

\section{MONITORING SALTWATER INTRUSION IN SOUTH CAROLINA RIVERS}

The location of the saltwaterfreshwater interface in a coastal river can be of critical importance in making freshwater withdrawals at a given point along the river and to the biological community capable of existing in and adjacent to the river. Long-term trends in saltwater intrusion may be an important index of changes in sea level, land subsidence, or river flow characteristics, all of which greatly impact water resources.

In cooperation with local, State, and Federal agencies the U.S. Geological Survey continuously monitors the location of the saltwater-freshwater interface in four rivers in South Carolina: The
Atlantic Intracoastal Waterway near Myrtle Beach, the Waccamaw River, the Cooper River, and the Savannah River. Because of the need for immediate information, three of these rivers are monitored in real time using satellite telemetry.

An efficient method for estimating the interface location has been to install a fixed conductance gage in the brackish zone of the river and correlate instantaneous readings with determinations of the interface location, made from a boat that follows high tide up the river. Such relations tend to have a high correlation coefficient and provide the capability to predict the interface location within 0.5 mile or less.

Results of specific conductance have not been collected for a long enough period to document longterm trends, but plans have been made to extend the saltwater intrusion record backwards in time using dendrochronological techniques. Many South Carolina rivers have a zone in which intruding saltwater has killed baldcypress trees. The record contained in the rings of these trees will be examined during the next phase of this investigation.

-Presenting author.

\section{ACCURACY OF USGS MINIMONITOR MEASUREMENTS IN LOW SOLUTE CONTENT STREAMS}

\author{
D. V. Peck*, M. A. Stapanian, \\ and R. C. Metcalf \\ Lockheed Engineering \& Sciences Company, Inc. \\ Environmental Programs Office \\ 1050 E. Flamingo Road, Suite 209 \\ Las Vegas, Nevada 89119
}

\author{
D. T. Heggem \\ U.S. Environmental Protection Agency \\ Environmental Monitoring \\ Systems Laboratory \\ Las Vegas, Nevada 89119
}

In situ measurements of chemical parameters provide the most representative data of water quality used in geochemical modeling, provided that the data are accurate. USGS MiniMonitor units are currently being used in the U.S. Environmental Protection
Agency's Episodic Response Project to collect in situ $\mathrm{pH}$ and conductivity data from small streams subject to acidic episodes. Evaluation studies of the MiniMonitor during snowmelt periods indicated the long-term field precision (2SD) was between \pm 0.2 and $\pm 0.3 \mathrm{pH}$ units, and $\pm 2 \mu \mathrm{S} / \mathrm{cm}$ at $25{ }^{\circ} \mathrm{C}$. These estimates were based on repeated measurements of quality assurance samples. For pH measurements, a dilute acid standard provided an equivalent, and less expensive, assessment of precision and bias as natural 
performance audit samples. In comparison, the long-term precision (2SD) of in situ measurements collected using Hydrolab Surveyor II units with Lazaran reference electrodes interfaced with DataLogger units was approximately $\pm 0.2 \mathrm{pH}$ units and approximately $\pm 20 \mu \mathrm{S} / \mathrm{cm}$ at $25^{\circ} \mathrm{C}$. Bias and precision of continuous monitoring data collected from dilute freshwater systems are suspect unless measurement performance is monitored and evaluated through a quality control program. Recommendations for developing and implementng such a program for MiniMonitor units will be presented.

Although the research described in this abstract has been funded wholly or in part by the U.S. Environmental Protection Agency under contract number 68-03-3249 to Lockheed Engineering and Sciences Company, it has not been subjected to the Agency review. It therefore does not necessarily reflect the views of the Agency, and no official endorsement should be inferred. Mention of trade names or commercial products does not constitute endorsement or recommendation for use.

*Presenting author.

\section{DEPRESSED REDOX POTENTIAL TO ENHANCE MICROBIAL DECHLORINATION OF PCBs}

\author{
Stephen F. Pedersen* \\ BCR National Labs \\ University of Pittsburgh Applied Research Center \\ 500 William Pitt Way \\ Pittsburgh, Pennsylvania 15238
}

\author{
Ronald D. Neufeld \\ University of Pittsburgh \\ Pittsburgh, Pennsylvania 15261
}

Polychlorinated biphenyls (PCBs) are a family of organic chemicals regulated under current environmental laws. The EPA has set limits on PCBs in the environment; disposal of contaminated materials less than $50 \mathrm{ppm}$ currently is not regulated. However, the U.S. Food and Drug Administration has set an upper limit of $2.0 \mathrm{mg}$ of PCBs per $\mathrm{kg}$ of fish flesh, for fish consumed by humans. Through bioconcentration in the food chain, PCBs less than $50 \mathrm{mg} / \mathrm{kg}$ in sediments in a waterbody may still cause fish to exceed the FDA limit.

To date, there are no commercial in-situ treatment processes. There are several experimental processes which are currently being studied, but no breakthrough is expected in the next 4-10 years. One process which offers a high potential of successfully eliminating PCBs at reasonable cost is in-situ biodegradation. Research is being conducted on a process using the anaerobic dechlorination of PCBs to accelerate degradation of the highly chlorinated, refractory PCBs.
A first phase screening experiment has been set up in duplicate. 12 gram portions of soil contaminated with $1000 \mathrm{ppm}$ of $2,2^{\prime}, 4,4^{\prime}, 5,5^{\prime}$ hexachlorobiphenyl were placed in $20 \mathrm{ml}$ vials. $5 \%$ by weight of alfalfa meal was added. Various reagents were added in 2 $\mathrm{ml}$ aliquots following the experimental design; distilled water was used for dummy variables.

Samples were taken from the screening experiment after 2 months and after 4 months. The samples were extracted in hexane by sonication, and the extracts were diluted 1:100, and analyzed by GC/ECD. Standard deviation of the retention times for the analyses was less than 0.2 secs.

A preliminary analysis of the data has been made. As many as three dechlorination byproducts have been observed. It is currently felt that the first byproduct is a tetrachlorobiphenyl; the second is a trichlorobiphenyl; and a third is a dichlorobiphenyl.

Some combination of variables resulted in little or no dechlorination; others caused partial dechlorination, and others resulted in substantial dechlorination. It currently appears that the most important factors are the anaerobic conditions (i.e., lack of oxygen), and strength of the reducing agent (1-cystine hydrochloride being "stronger" than sodium dithionite). It appears that using seed material has no impact on the process.

The high degree of specificity of the retention times for the dechlorination products strongly suggests that a biological process is occurring; if the process was chemical, a large number of compounds for each dechlorination product (tetra-, tri-, or di-chlorobiphenyl) would be expected.

The computer program associated with the experimental design will be run, and a more detailed analysis made of the results of the screening experiment. In addition, a second set of sample will be taken, and the $\mathrm{eH}$ of the vials measured.

"Presenting author. 


\title{
OCCURRENCE, DISTRIBUTION, TRANSPORT AND FATE OF SYNTHETIC ORGANIC CONTAMINANTS IN THE LOWER MISSISSIPPI RIVER AND ITS MAJOR TRIBUTARIES
}

\author{
W. E. Pereira*, C. E. Rostad, and T. J. Leiker \\ U.S. Geological Survey \\ P.O. Box 25046, Mail Stop 408 \\ Denver, Colorado 80225
}

Historically, comprehensive water quality studies in large river basins have been hampered by several factors such as the magnitude of these studies, lack of suitable sampling methods and equipment, and specificity and sensitivity of analysis for trace organic contaminants.

Studies being conducted in the Lower Mississippi River and its major tributaries have overcome many of these problems. These studies indicate that many synthetic organic compounds derived from point and nonpoint sources have degraded the water quality of this riverine system. The Missouri, Upper Mississippi, Illinois and
Ohio Rivers are significant contributors of herbicides and their degradation products. These compounds include atrazine, and its degradation products, desethyl and desisopropylatrazine; cyanazine; simazine; metolachlor; and alachlor and its degradation products, 2-chloro-2',6'-diethylacetanilide, 2-hydroxy-2',6'diethylacetanilide, and 2,6diethylaniline. Chloroalklphosphate flame retardants in the Lower Mississippi River are exclusively contributed by the Illinois River. The compound 1,3,5trimethyltriazine-2,4,6-trione, an industrial byproduct, had its genesis in the Ohio River. These compounds were determined in representative water samples using gas chromatography-ion trap mass spectrometry.

Stream-load calculations for these compounds provided information concerning (a) point or nonpoint sources, (b) conservative or nonconservative behavior, (c) validation of sampling techniques, (d) transport in the river, and (e) fate. Many of these compounds are transported significant distances in this riverine system and eventually are discharged into the Gulf of Mexico.

"Presenting author.

\section{EXPERIMENTAL SURFACE-WATER SAMPLING DEVICE FOR AGRICULTURAL FIELD-RUNOFF INVESTIGATIONS}

\author{
Charles A. Perry* and E.M. Thurman \\ Kansas District \\ U.S. Geological Survey \\ 4821 Quail Crest Place \\ Lawrence, Kansas 66049
}

An experimental sampling device for surface-water runoff has been developed for use on small plots of agricultural row crops. The sampler is self-contained and utilizes solar power, which allows it to be placed at any location within a field. The sampler gathers surface runoff between the rows, and a pipe manifold directs the sample by gravity flow to containers arranged in series. As each container is filled, a flapper valve closes, directing the runoff water to the next container. An electronic switch closes when the container is full, and the container and the time that it was filled is recorded by a datalogger. Rainfall amounts and times are also recorded by the datalogger, allowing the measurement of rainfall-runoff episodes. Accessory equipment includes a bilge pump to extract water from around the sampler container to prevent flotation of the device.

The experimental sampling device was used to collect watersediment mixtures from a corn field on which herbicides were applied.
The purpose was to collect samples with representative sediment-towater ratios from the edge of the field during intense rainfall. Atrazine and alachlor were detected at concentrations ranging from 1 to 3 milligrams per liter in surface runoff from the first rainfall following herbicide application. Twenty percent of the transported herbicides were sorbed to sediment, and 80 percent were dissolved.

- Presenting author. 


\section{GEOCHEMICAL PROCESSES AFFECTING STREAMWATER SOLUTE COMPOSITION AND TRANSPORT IN A FORESTED PIEDMONT WATERSHED}

\author{
Norman E. Peters \\ U.S. Geological Survey \\ Water Resources Division \\ 6481-B Peachtree Industrial Blvd. \\ Doraville, Georgia 30360
}

Precipitation, ground water, and surface water were collected intensively during rainstorms at a small (41 hectare) forested watershed, underlain predominantly by granite, at Panola Mountain, Georgia. An evaluation of these data indicates that cation exchange may have an increasingly important effect on the composition of streamwater as streamflow increases during rainstorms. At base flow, the concentrations of major ions in streamwater are similar to those in adjacent ground water. The source of these major ions, in general, is consistent with rock weathering. For example, the ratio of dissolved silica to sodium plus potassium is approximately two at base flow, a value that is consistent with the stoichiometry of feldspar weathering to kaolinite. During base flow, the streamwater chemistry is dominated by sodium and bicarbonate, but during higher flow during a rainstorm the chemistry is dominated by calcium and sulfate. During base flow, the sulfate concentration in streamwater typically varies between 10 and $\mathbf{4 0}$ microequivalents per liter, which is attributed to control by soil sulfate adsorption, whereas, during rainstorms, the stream sulfate concentration frequently exceeds 100 microequivalents per liter, which is more typical of the average composition of rainfall ( 80 microequivalents per liter). The streamwater concentration of each base cation and silica decreases as discharge increases, which is consistent with the dilution of base flow concentrations by precipitation. But, the concentration ratio of dissolved silica to sodium-pluspotassium decreases from two to one as discharge (and sulfate concentration) increases, indicating an additional source of sodium or potassium. Exchange sites are hypothesized to be the additional source. The resulting relative increase in sodium and potassium concentrations above those derived from weathering maintains electroneutrality with the concurrent increase in the sulfate concentration. The relative increase in the calcium concentration compared to sodium also is consistent with this hypothesis because the calcium is much more dominant on the exchange sites.

\section{ANALYSIS OF TOTAL NITROGEN IN NATURAL WATER SAMPLES USING PYROCHEMILUMINESCENCE - A SMALL VOLUME, ACID-FREE TECHNIQUE}

\author{
Linda K. Pratt* and Merle W. Shockey \\ U.S. Geological Survey \\ National Water Quality Laboratory \\ Inorganics Program \\ 5293-B Ward Road \\ Arvada, Colorado 80002
}

Currently, the National Water Quality Laboratory analyzes for total nitrogen in water using a Kjeldahl digestion. This method involves a lengthy ( 3 hour), multistep digestion using sulfuric acid at high temperatures, a mercuric sulfate catalyst, relatively large sample volumes (20 milliliters), and extensive manual preparation work. A pyrochemiluminescence method is now available for the analysis of total nitrogen. This method completely eliminates the need for the lengthy and hazardous preparation work required by the Kjeldahl analysis. Through the use of an autosampler, a 5 to 10 microliter aliquot of the sample is injected into a quartz reaction tube where it is subjected to high temperatures (1100 degree Celsius) in an oxygen-rich atmosphere. Reduced, oxidized, and organic nitrogen-containing species are converted to nitrous oxide (NO), which can be detected 
photometrically following reaction with ozone. This technique requires no manual digestion or sample preparation, and samples can be analyzed at the rate of approximately 30 per hour. The elimination of sample preparation and the increased automation has resulted in a detection limit of 0.10 $\mathrm{mg} / \mathrm{L}$ (milligrams per liter), and improved precision over a range of 0.10 to $5.0 \mathrm{mg} / \mathrm{L}$ total nitrogen/L.
Presently, this method has been developed only for dissolved ( 0.45 micron filtered) samples.

* Presenting author.

\section{WATER QUALITY INDEX SYSTEM OF THE BRAZOS RIVER AUTHORITY}

\author{
Philip W. Price \\ Brazos River Authority \\ 4400 Cobbs Drive \\ P.O. Box 7555 \\ Waco, Texas 76714-7555
}

In order to translate USGS water quality sampling data for water supply reservoirs and critical stream segments in the Brazos River Basin into a form which can be easily understood and applied in examining trends, a water quality index has been developed.
This paper describes the formulation of the water quality index and its application in the evaluation of the level of pollution in the Brazos River Basin. Water quality data collected by the USGS was used to develop a subindex on a scale from 1 to 100 for each pollutant variable. The sub-indices were aggregated by a multiplicative method. The water quality index is used to evaluate the relative quality of waterbodies as well as trends in quality.

\section{ASSURING DATA QUALITY AT THE U.S. GEOLOGICAL SURVEY NATIONAL WATER QUALITY LABORATORY}

Each year, the National Water Quality Laboratory (NWQL) of the U.S. Geological Survey analyzes more than 50,000 water samples and determines more than 600,000 constituent concentrations. The ability to discover inaccurate data quickly, to monitor the performance of instrumentation and analysts on a routine basis, and to initiate corrective action procedures when necessary is critical to the quality assurance program. A

\author{
Jeffrey W. Pritt \\ U.S. Geological Survey \\ National Water Quality Laboratory \\ Quality Control Unit \\ 5293-B Ward Road \\ Arvada, Colorado $\mathbf{8 0 0 0 2}$
}

variety of control and reference samples are determined routinely as part of the program. Some are obtained externally from the NWQL, such as from the U.S. Environmental Protection Agency and the U.S. Geological Survey Branch of Quality Assurance, and provide a basis for the laboratory's certification. The remainder are internal blind samples introduced to the appropriate sections of the production laboratory by the
Quality Control unit. Between 15 and 20 percent of analyses performed at the NWQL are control or reference samples. Current within-laboratory quality control methods include review of blind sample analyses within 24 hours, construction and maintenance of control charts, and corrective action procedures when inaccurate data are discovered. 


\author{
Jeffrey W. Pritt \\ U.S. Geological Survey \\ National Water Quahity Laboratory \\ 5293-B Ward Road \\ Arvada, Colorado 80002
}

To reduce the possibility of contamination, containers and preservatives purchased for field sample collection undergo quahty assurance acceptance testing by the Quality Control unit at the National Water Quality Laboratory (NWQL) of the U.S. Geological Survey. When a shipment of containers or ampules from an approved supplier is received by the NWQL, a testing schedule based on a statistical sampling plan is implemented. The data collected are reviewed and compared to acceptance criteria. The materials are either accepted for field use or rejected and quarantined from accidental release to field personnel. The information obtained from each cycle of testing is added to a computerized data base that is used for assessing future risks for trace metals, nutrients and mineral contamination. The overall plan for acceptance testing of bottles and preservatives consists of statistical sampling from the batch of bottles or preservatives, chemical testing for possible contamination, data review and computerized data recording.

\section{WATER-CHEMISTRY AND BIOLOGICAL RECONNAISSANCE OF CORE MATERIAL FROM HYDROGEOLOGIC UNITS IN THE COASTAL PLAIN OF NEW JERSEY}

\author{
Amleto A. Pucci, Jr.* and Ted Ehlke \\ U.S. Geological Survey \\ New Jersey District Office \\ 810 Bear Tavern Road \\ W. Trenton, New Jersey 08628
}

\author{
James P. Owens \\ U.S. Geological Survey \\ Geologic Division \\ National Center, Mail Stop 926 \\ 12201 Sunrise Valley Drive \\ Reston, Virginia 22092
}

Sediment and pore-water samples were extracted from Tertiary and Cretaceous core material from multiple levels at three sites in the New Jersey Coastal Plain. Sediments were collected from a 1,325-foot-long continuous core in Freehold Township, Monmouth County, from five short cores drilled to a depth of 1,250 feet in Howell Township, Monmouth County, and from a 1,000-foot-long continuous core in Clayton Township, Gloucester County. The cored materials consist of sediments that form a multilayered aquifer system in the Coastal Plain. The upper strata at all three sites are of marine origin and the lower strata are primarily nonmarine.

Total concentrations of silica, anions, and cations in the porewater samples differed with depth. Pore-water chemical types in confining units were distinct from those in aquifers, particularly in the marine deposits. Carbonate dissolution and cation-exchange reactions, common in Coastal Plaim sediments, may partly explaim the variation in water quality. Undocumented processes may be the cause of high ionic strength and elevated concentrations of sulfate in pore waters in marine confiningunit sediments.
Bacteriological samples were collected at the Howell and Clayton Township sites. Determinations of microbial biomass were made by microscopy. Viability of sulfate-reducing and sulfide-oxidizing populations was determined using a culturing medium prepared to resemble in-situ pore-water geochemistry. Sediment samples from cores from four depths at the Howell Township site were incubated in lactate to study sulfate reduction. Some activity was observed in one core from a depth of 210 feet, where the number of bacteria ranged from $10^{3}$ to $10^{6}$ per gram of soil.

*Presenting author. 


\author{
Karen C. Rice* \\ U.S. Geological Survey \\ 208 Carroll Building \\ 8600 LaSalle Road \\ Towson, Maryland 21204
}

\author{
Owen P. Bricker \\ U.S. Geological Survey \\ National Center \\ National Research Program, NE Region \\ MS 432 \\ Reston, Virginia 22092
}

The U.S. Geological Survey has monitored precipitation and stream-water chemistry in northcentral Maryland since 1982 as part of the National Acid Precipitation Assessment Program. Precipitation in the area is acidic ( $\mathrm{pH}$ about 4.0). Sulfate and hydrogen are the dominant anion and cation, respectively. Sodium is the dominant base cation in precipitation.

A headwater tributary in the study area has been monitored weekly since October 1987 for $\mathrm{pH}$, specific conductance, and major anions and cations. The 104-hectare forested watershed is underlain by quartzose bedrock. The stream water $\mathrm{pH}$ ranges from 5.5 to 6.6. The stream water is dilute and has a specific conductance generally less than 20 microsiemens per centimeter at 25 degrees Celsius. The predominant anion differs according to season; sulfate (with a concentration of $\mathbf{3 0}$ to 90 microequivalents per liter) dominates during the winter, and bicarbonate (with a concentration of 0 to 70 microequivalents per liter) dommates during the rest of the year. Cations are less variable seasonally; sodium concentration ranges from 30 to $60 \mathrm{micro-}$ equivalents per liter, calcium concentration ranges from 35 to 50 microequivalents per liter, and magnesium concentration ranges from 35 to 60 microequivalents per liter.

Preliminary calculations suggest that 37 percent of the base cations in the stream water are derived from atmospheric deposition. The remaining 63 percent of the base cations in the stream water are generated by watershed processes, including chemical weathering of the bedrock in the watershed.

*Presenting author.

\title{
COMPARISON OF ANALYTICAL APPROACHES FOR ASSESSING TRACE-ORGANIC COMPOUNDS IN THE YAKIMA RIVER BASIN, WASHINGTON
}

\author{
Joseph F. Rinella*, Stuart W. McKenzie, and Gregory J. Fuhrer \\ U.S. Geological Survey \\ Pacific Northwest District \\ National Water Quality Assessment Program \\ 10615 S.E. Cherry Blossom Drive \\ Portland, Oregon 97216
}

The Yakima River basin is one of four surface-water project areas in the U.S. Geological Survey's pilot National Water-Quality Assessment Program where techniques for data collection and analysis are being evaluated. Objectives of the assessment include determining the variability and sources of traceorganic contaminants in the basin. In this paper, results from conventional and new approaches are compared.
One new approach, developed at the Oregon Graduate Center, allows for the direct analysis of sediment samples as small as $\mathbf{1 0 0}$ milligrams using thermal desorption injection with a gas chromatograph/mass spectrometer detector. This approach provides for separate analyses of dissolved and suspended trace-organic compounds while maintaining conventional analytical detection levels. Preliminary results show a slight positive bias when compared to results from conventional approaches.

Another new approach involves the on-site extraction of large volumes (up to 120 liters) of filtered water in a continuous flow-through chamber. Advantages of this procedure over conventional procedures include: (1) improved sample preservation, (2) lower analytical detection levels, (3) continuous sampling that is representative of a longer time frame, and (4) separate analyses of dissolved and suspended 
compounds. About $\mathbf{4 0}$ pesticides were selected for analyses on the bases of (1) recent application, (2) historical application and their persistence in streams, and (3) analytical detection levels that were environmentally significant. Twenty of these $\mathbf{4 0}$ pesticides were detected in surface water in the Yakima River basin.

Results from the conventional approaches are generally consistent with those from the new approaches. Data indicate that organochlorine compounds and parathion are pervasive in the lower basin. During irrigation season, concentrations of these compounds were larger than Washington State standards for protection of freshwater aquatic life from chronic toxicity. In general, hydrophobic and hydrophilic pesticides showed their largest concentrations during peak irrigation in July.

\title{
THE NATIONAL STATUS AND TRENDS PROGRAM FOR MARINE ENVIRONMENTAL QUALITY: MONITORING TOXIC CONTAMINATION IN U.S. COASTAL WATERS
}

\author{
Andrew Robertson \\ Oceans Assessments Division \\ Office of Oceanography and Marine Assessment, NOAA \\ Rockville, Maryland 20852
}

The National Oceanic and Atmospheric Administration initiated a monitoring and assessment program for U.S. marine coastal waters, the National Status and Trends for Marine Environmental Quality, in 1984. The purpose of this program is to make systematic observations at carefully selected coastal locations using meaningful indicators of marine environmental conditions in order to determine the present condition of, and to detect changes in, the quality of our coastal environments. The program is presently focused on toxic substances and is measuring the concentrations of organic and inorganic contaminants and levels of associated biological effects in biota (bivalves and fish) and sediments at over 200 sites around our coasts. The program is structured in three tiers--a broad field survey Level I that provides warning as to the regions along our coasts with the highest levels of contamination and bioeffects; Level II where the areas of the highest concern from the first level are assessed in detail using all available historical data; and Level III which provides field surveys to test hypotheses concerning magnitude and extent of existing and potential contaminant effects developed in Levels I and II. The results from the first several years of this program are now available and will be briefly illustrated. In general, the sites of greatest concern are near major coastal urban centers as expected. However, for certain specific toxics, especially several of the organic contaminants, surprisingly high levels have been found in unexpected sites well away from major urban centers.

\section{PREDICTION OF WATER QUALITY THROUGH GEOCHEMICAL MODELING IN UNDEVELOPED AREAS IN THE DESERT SOUTHWEST}

\author{
Frederick N. Robertson \\ U.S. Geological Survey \\ Water Resources Division \\ Federal Building, FB-44 \\ 300 West Congress Street \\ Tucson, Arizona 85701-1393
}

Geochemical models developed for interpretation of the regional hydrology can provide much information on the occurrence of natural trace and major elements in the ground water. Quantitative chemical models can distinguish open and closed evolutionary systems and indicate the distribution of recharge and ground-water flow in alluvial basins in the desert Southwest. As reactions in closed 
Geochemical models developed for interpretation of the regional hydrology can provide much information on the occurrence of natural trace and major elements in the ground water. Quantitative chemical models can distinguish open and closed evolutionary systems and indicate the distribution of recharge and ground-water flow in alluvial basins in the desert Southwest. As reactions in closed systems can be defined, the concentrations of the major dissolved ions and the occurrence of some trace elements in these systems can be predicted with a high degree of reliability. The concentration of all major ions can be estimated by knowing the sulfate and chloride concentrations, the geographic location within the basin, and the reactions that control groundwater chemistry as defined by the modeling process.

Analyses for chloride and sulfate concentrations in water can be done quickly, inexpensively, and accurately in the field. Where a water sample is not available, concentrations can be determined from analyses of aquifer material. Leachate from 2 to 4 grams of aquifer material was analyzed for chloride and sulfate using ion chromatography, and the results agreed favorably with concentrations of these ions in the underlying ground water. Thus, ground-water compositions for all major ions can be estimated by analyses of smalldiameter drill core or of aquifer material that already exists in repositories. These methods may be applied to open systems if large dissolved-solids concentrations are anticipated. Some predictability is possible because salinity increases are related primarily to dissolution of halite and gypsum and their mediation of other ions. The chemical models may also suggest the presence of several trace elements in ground water. Occurrences of fluoride, hexavalent chromium, arsenic, selenium, and molybdenum may be anticipated in certain areas in basins as their occurrence is favored by closed evolutionary processes. The application of modeling and geologic information is a potentially powerful tool for the evaluation of water quality in undeveloped areas in the Southwest.

\section{ESTIMATING HISTORICAL RIVER POLLUTION TRENDS USING MASS BALANCE PRINCIPLES: SELECTED METALS IN THE HUDSON-RARITAN BASIN, 1880 to 1980}

\author{
Samuel R. Rod \\ National Academy of Engineering \\ 2101 Constitution Avenue, NW \\ Washington, DC 20418
}

The historical loadings of lead, mercury, cadmium and copper onto land and into surface waters of the Hudson and Raritan River basins from 1880 to 1980 are reconstructed to demonstrate an application of material balance principles to multimedia pollution transport modeling.

The methodology models the river basin as a source-receptor matrix. The Hudson-Raritan basin is divided both geographically and by environmental medium, and mass conservation conditions are imposed. Information to complete material cycles and quantitative mass balances is derived from existing data and transport models. The method can identify major pollutant source categories, key pathways and concentration points within the basin, and containinant accumulations over long time periods.

Analyses reveal roughly similar emission and river loading trends for cadmium, copper, mercury and lead. Both emission and river loadings of the four metals increased from 1880 to around 1945 , then fluctuated until they peaked in the late 1960 's. Since 1970, emission and river loadings of cadmium, copper, lead and mercury have all declined. Historical trends in metal emissions and loadings to surface waters compare well to metal deposition rates in dated river sediment cores. 


\section{IDENTIFICATION OF ORGANIC CONTAMINANTS BY GAS CHROMATOGRAPHY/HIGH-RESOLUTION MASS SPECTROMETRY}

\author{
Peter F. Rogerson \\ U.S. Geological Survey \\ National Water Quality Laboratory \\ 5293 Ward Road \\ Arvada, Colorado $\mathbf{8 0 0 0 2}$
}

Water quality studies of organic contaminants typically use either a preselected list of target analytes, such as pesticides, or non-target analytical techniques. In situations where it is not possible to predict what contaminants are present, non-target methods are used to determine what organic contaminants are present. The method of choice for non-target analysis is gas chromatography/mass spectrometry (GC/MS).

For those unknown contaminants that are amenable to GC/MS and are at concentrations greater than the detection limit, a characteristic mass spectrum can be generated. Without additional information, this mass spectrum can only tentatively identify a particular contaminant. To confirm this identification, an authentic standard must be co-injected and produce the same retention time and mass spectrum as the unknown. However, selecting all reasonable candidate standards, procuring them, and testing the match between standard and unknown is tedious. Highresolution mass spectrometry (HRMS) can be applied to limit the number of candidate standards.

The technique of HRMS involves measuring the exact mass-charge ratio of the characteristic ions in a spectrum and calculating the elemental formulas of those ions which exhibit those exact masses. This process results in proposed ion formulas of unknown contaminants, but will not distinguish between isomers. Although the results of this analysis cannot be considered truly confirmed without co-injection of an authentic standard, a molecular formula will eliminate most incorrect tentative identifications. Applications of this technique to sediment and water extracts from two surface water National Water Quality Assessment sites in Illinois and the Yakima River were very effective.

\section{DETERMINATION OF HALOGENATED ORGANIC COMPOUNDS IN MISSISSIPPI RIVER SUSPENDED SEDIMENT BY NEGATIVE ION CHEMICAL IONIZATION MASS SPECTROMETRY}

The dissolved phase of the water column of the lower Mississippi River has been found to contain mainly hydrophilic compounds. Hydrophobic organic compounds with high octanol/water partition coefficients are often associated with the particulate phase. To determine transport of hydrophobic organic contaminants associated with the particulate phase in the lower Mississippi River and its major tributaries, suspended sediment samples were collected from 17 sites. The suspended sediment was dewatered, dried, extracted, and analyzed by gas chromatog-

\section{E. Rostad*, W. E. Pereira and T. J. Leiker \\ U.S. Geological Survey \\ P.O. Box 25046, Mail Stop 408 \\ Denver, Colorado 80225}

raphy/mass spectrometry. Electron ionization mass spectrometry revealed primarily hydrocarbons, polycyclic aromatic hydrocarbons, and sterols which masked the halogenated compounds of interest. Negative ion cliemical ionization was utilized to provide specificity and enhanced sensitivity, while eliminating interferences. Compounds, such as pentachlorobenzene, hexachlorobenzene, pentachloroanisole, chlorothalonil, dachthal, chlordane, nonachlor, and penta-, hexa-, hepta-, and octachlorobiphenyls, were detected at nanograms per gram dry silt con- centrations. The concentrations of the hydrophobic organic compounds in the suspended sediments were normalized to organic carbon content. Transport of the hydrophobic organic compounds on the suspended sediment at the 17 sites on the Mississippi River was estimated. The lower detection limits provided by negative ion chemical ionization provide a more complete description of the distribution, fate, and transport of organic compounds associated with suspended sediment.

"Presenting author. 


\section{MERCURY AND SELENIUM CONCENTRATIONS IN SURFACE WATER, BOTTOM SEDIMENT, AND BIOTA, STILLWATER WILDLIFE MANAGEMENT AREA AND VICINITY, CHURCHILL COUNTY, NEVADA}

\author{
Timothy G. Rowe \\ U.S. Geological Survey \\ Water Resources Division \\ Nevada District Office \\ Room 227, Federal Building \\ Carson City, Nevada 89701
}

The U.S. Geological Survey, in cooperation with the U.S. Fish and Wildlife Service and U.S. Bureau of Reclamation, investigated the occurrence of potentially toxic trace elements associated with irrigation-drainage water at the Stillwater Wildlife Management Area (WMA) and vicinity during 1986-88. Results of this investigation show that mercury and selenium are present at elevated concentrations (exceeding background levels) in bottom-sediment and biota samples, but not in surface-water samples. All concentrations of dissolved mercury [range, $<0.1$ to 0.9 micrograms per liter $(\mu \mathrm{g} / \mathrm{L})]$ and dissolved selenium ( $<1$ to $3 \mu \mathrm{g} / \mathrm{L}$ ) in surfacewater samples were less than the Nevada water-quality criteria for aquatic life (4.1 and $260 \mu \mathrm{g} / \mathrm{L}$, respectively) and most of the con- centrations were less than the analytical reporting himits ( 0.1 and $1 \mu \mathrm{g} / \mathrm{L}$, respectively). In contrast, concentrations of both elements exceeded background levels [0.08 milligrams per kilograms (mg/kg) and 0.1 micrograms per gram $(\mu \mathrm{g} / \mathrm{g})$, dry weight] in bottom-sediment and biota samples. The biota samples consisted of bird livers, fish tissue, insect tissue, and plant matter. Mercury concentrations were highest in bottom-sediment $(18 \mathrm{mg} / \mathrm{kg})$ and biota $(25 \mu \mathrm{g} / \mathrm{g}$, dry weight for bird livers, $5.7 \mu \mathrm{g} / \mathrm{g}$ for fish, $5.4 \mu \mathrm{g} / \mathrm{g}$ for insects, and 7.3 $\mu \mathrm{g} / \mathrm{g}$ for plants) samples from the terminal ponds at Carson Lake wetlands and Stillwater WMA, and in bottom-sediment samples from the Carson River. High $(6.6 \mathrm{mg} / \mathrm{kg}$ for bottom material, $21 \mu \mathrm{g} / \mathrm{g}$ dry weight for bird livers, and $5.4 \mu \mathrm{g} / \mathrm{g}$ for fish) mercury concentrations also were detected at some of the sampling sites not affected by irrigation-drainage water and probably reflect 19 th-Century ore-milling activities. The highest concentrations of selenium in bottom-sediment $(1.2 \mathrm{mg} / \mathrm{kg})$ and biota ( $48 \mu \mathrm{g} / \mathrm{g}$, dry weight for bird livers, $11 \mu \mathrm{g} / \mathrm{g}$ for fish, $13 \mu \mathrm{g} / \mathrm{g}$ for insects, and $7.9 \mu \mathrm{g} / \mathrm{g}$ for plants) were detected in samples from the terminal ponds at Carson Lake wetlands, Stillwater WMA, Fernley WMA, Humboldt WMA, and Massie and Mahala Sloughs. Concentrations of mercury and selenium detected in bottomsediment samples correlate significantly with particle-size distribution: samples with the smallest particle sizes characteristically had the highest concentrations of mercury and selenium.

\section{RELATIONS BETWEEN FISH POPULATIONS AND WATER QUALITY IN THE UPPER ILLINOIS RIVER BASIN IN ILLINOIS, INDIANA, AND WISCONSIN: ANALYSIS OF EXISTING INFORMATION}

\author{
Peter M. Ruhl* \\ U.S. Geological Survey \\ 102 East Main Street, 4th Floor \\ Urbana, Illinois 61801
}

\author{
Robert G. Striegl \\ U.S. Geological Survey, Water Resources Division \\ Box 25046 \\ Denver Federal Center, MS 413 \\ Denver, Colorado 80225
}

\begin{abstract}
Assessment of changes in the water quality of streams traditionally has been approached by measurement of the chemical and physical properties of water and sediment. However, adequate assessment of the effects of
\end{abstract}

changes in chemical and physical properties on aquatic systems requires direct measures of lethal and sublethal biological responses. Available data on water and sediment chemistry and on fish populations and fitness were compiled for several locations in the upper Illinois River basin. The locations represent comparatively undisturbed headwaters and areas that are affected by agricultural, urban, and industrial development. Fish communities in reaches with 
similiar flow regimes and physical structure, yet differing water- and sediment-chemistry conditions, were compared. This approach enhanced the ability to isolate the responses of fish communities to water- and sediment-chemistry conditions from responses to flow regime and physical structure.
Responses of fish communities to contamination, including multivariate analyses of the spatial distribution and the absolute and relative abundance of fish species; relative weights of predominant species; and an index of biotic integrity were described and summarized by a variety of methods. Although results of most analytical methods indicate a relation between water quahity and fishcommunity composition and structure, a single "most-reliable" method for determining this relation has yet to be determined.

*Presenting author.

\title{
TRANSPORT OF CHLORIDE AND ATRAZINE THROUGH THE UNSATURATED ZONE BENEATH TWO IRRIGATED FIELDS IN SOUTH-CENTRAL KANSAS
}

\author{
A. T. Rutledge* \\ U.S. Geological Survey \\ Water Resources Division \\ 3600 West Broad Street, Room 606 \\ Richmond, Virginia 23230
}

\author{
J. O. Helgesen \\ U.S. Geological Survey \\ Water Resources Division \\ 4821 Quail Crest Place \\ Lawrence, Kansas 66049
}

Two irrigated fields were instrumented in spring 1988 to define subsurface movement of water and agricultural chemicals, with particular emphasis on the movement of atrazine. A chloridetracer test at one field indicated a transport time through the root zone of less than 1 month and a seepage velocity below the root zone of about 4.6 feet per year. Chloride tracing at the other field indicated a transport time through the root zone of approximately 3.5 months; not enough data were available to determine seepage velocity. After an initial increase, chloride concentrations in the unsaturated zone beneath the second field remained relatively stable, possibly because of stagnation of flow or because of residual chloride ions in the interstitial water.

Water samples collected from June to November in 1988 at depths of 6 to 10 feet showed no definitive movement of atrazine. A possible explanation is that the atrazine detected was applied before 1988 , and that the 1988 atrazine application had not reached the 6- foot depth during 1988 because of retardation. This interpretation is supported by analyses of soil samples that showed the largest concentrations of atrazine in the top 0.3 foot at a time when chloride (applied at the same time as the atrazine) had already reached a depth of 6 feet. A mathematical model shows that below the root zone atrazine follows a nonadsorbing tracer by approximately 1.2 years.

* Presenting author.

INVESTIGATION OF THE STRUCTURAL FEATURES AND INTERACTIONS OF AQUATIC FULVIC ACIDS IN SURFACE AND GROUNDWATER

\author{
Farida Y. Saleh*, Wenching Ong, Inyoung Kim, and Qasem Haj-Mahmoud \\ Institute of Applied Sciences \\ Department of Chemistry \\ University of North Texas \\ P.O. Box 13078 \\ Denton, Texas 76203
}

Structural features and interactions of aquatic fulvic acids (FA) were investigated by combined chromatographic and spectroscopic techniques. Analytical and preparative reserved-phase liquid chromatography were used to separate constituents of FA. Photodiode array, ultraviolet, and fluorescence detectors were used to monitor the HPLC separation. Preparative FA fractions were subjected to ${ }^{1} \mathrm{H}$ and ${ }^{13} \mathrm{C}$ solid state NMR, FT-IR and ESR as well as other separation and derivatization techniques. Fulvic acid interactions with $\mathrm{Cu}^{2+}$ and tetrachlorobenzene isomers 
were investigated by ESR and HPLC and GC-MS. A catalogue of the uv-vis scans of FA constituents was developed using RP-HPLC under different mobile phases and gradient programs. The overall results indicate that: i) FA macromolecule consists of a molecular complex which can be separated into three to six subunits; ii) Each subunit may contam two or three structurally related compounds; iii) Vanillic acid and conjugated ketones and phenols represent the backbone structures in FA; iv) The free radical in FA regulates the transformations of $1,2,4,5 \mathrm{TCB}$ in aqueous solution but does not influence its aqueous solubility; v) At least four binding sites in FA participate in complexation with $\mathrm{Cu}^{2+}$. The first available sites are those participating in square planar complexes.
Research is supported by the U.S. Geological Survey, Department of Interior Assistance Award No. 14-08-0001-G1146. The views and conclusions contained in this document are those of the authors and should not be interpreted as necessarily representing the official policies, either expressed or implied of the U.S. Government. * Presenting author.

\section{FIELD METHOD FOR SOLID-PHASE EXTRACTION OF HERBICIDES IN SURFACE AND GROUND WATER}

\author{
Mark W. Sandstrom \\ U.S. Geological Survey \\ National Water Quality Laboratory \\ 5293 Ward Road \\ Arvada, Colorado 80002
}

\begin{abstract}
A field method using solid-phase extraction (SPE) was developed to isolate herbicides in water samples. Subsequent analysis was by capillary gas chromatographymass spectrometry (GC-MS) with selected ion monitoring (SIM). Water samples ( 100 to 500 milliliters) were processed at the collection site by filtration through 0.7-micrometer glass-fiber filters to remove suspended solids, then by pumping, at rates of 25 to 30 bed volumes per minute, through SPE cartridges containing octadecyl (C-18) bonded to porous silica.
\end{abstract}

The adsorbed compounds were removed from the SPE cartridges in the laboratory by elution with 1.8 milliliters of hexane-isopropanol and analyzed by GC-MS with selected ion monitoring of parent and two characteristic ions. Excellent performance of the method was indicated by average recoveries of greater than 84 percent for organonitrogen herbicides added to river- and groundwater samples at concentrations of 0.5 to 1.0 micrograms per liter. The method uses matrix field spikes to monitor extraction efficiency and degradation during shipping. Recoveries of field surrogates indicated no loss of analytes during shipping or storage prior to laboratory analysis. The method has detection levels (0.5 micrograms per liter) similar to or better than conventional liquidliquid extraction, but utilizes smaller sample volumes, and more rapid, less expensive laboratory procedures. This method offers new opportunities for monitoring organic contaminants in synoptic surveys, runoff events, and the soil unsaturated zone.

\section{TREND ANALYSIS OF TEXAS WATER-QUALTY DATA}

\author{
Terry L. Schertz \\ U.S. Geological Survey \\ Texas District \\ 8011 Cameron Road, Building 1 \\ Austin, Texas 78753
}

\author{
Timothy L. Miller* \\ U.S. Geological Survey \\ Office of Water Quality \\ National Center, MS 412 \\ Reston, Virginia 22092
}

Data from dense state-wide fluvial water-quality networks are available to augment and extend results from national network water-quality trend analyses. The Texas water-quality network provides data that are compatible with data from the national network and is, at a smaller scale, suitable for detailed analysis of regional water-quality patterns. In this study, trend analyses were made on: (a) 40 water-quality constituents at 117 stations for the 1975-86 water years, and (b) 35 constituents at 98 stations for the 1969-86 water years. Waterquality data for each time period 
were examined for sampling density to identify appropriate seasonal periods prior to application of the trend test. Subsequent to identification of seasons, trend significance and magnitude was determined by using the seasonal Kendall test. The trend slope estimator was applied to concentration data before and after flow adjustment. Data-density examination, trend identification, and flow-adjustment procedures were all facilitated through a package of FORTRAN programs developed for analyzing this large data base.

Detectable trends showed that most inorganic constituents decreased for both the 1975-86 and 1969-86 water year periods, although inorganic constituents in several regions of the state increased during these time periods. Decreasing trends were evident in the lower and coastal plains of Texas while increasing trends predominated in the upper reaches of the Red, Brazos and Colorado River basins during both time frames for almost all of the dissolved ions, total hardness, and specific conductance. Increasing trends in the Rio Grande basin for the same constituents are evident for the 1975-86 period. Sulfate increased in the eastern coastal region of the state during both time frames, while other dissolved ions decreased in this region.

The regional trend patterns for nutrients and dissolved oxygen in the upper Trinity River basin indicate that there has been improvement in water-quality over both time periods. Concurrent degradation has occurred in the water-quality of the San Antonio and Guadalupe Rivers. Increases in $\mathrm{pH}$ were the norm across the State during both periods, whereas alkalinity predominantly decreased for both periods. Concentrations of trace elements and pesticide constituents were generally low and often less than the analytical detection limit. Few trends were detected for any of these constituents and no regional patterns were detected.

Evaluation of possible causes of the detected water-quality trends requires ancillary information on land use, pollution sources and other environmental factors. Statistical associations between observed trends and ancillary information are currently being examined to assist in the interpretation of the trend results.

"Presenting author.

\title{
ALTERNATIVES TO THE MEASUREMENT OF TISSUE CONCENTRATIONS FOR DOCUMENTING EXPOSURE TO AND EFFECTS OF CONTAMINANTS IN FISH
}

\author{
Christopher J. Schmitt* and Byran L. Steadman \\ U.S. Fish and Wildlife Service \\ National Fisheries Contaminant Research Center \\ Route 2, 4200 New Haven Road \\ Columbia, Missouri 65202
}

Trends in contaminants monitoring data indicate that regulatory measures have succeeded in reducing environmental concentrations of some persistent organochlorine chemical residues and potentially toxic elemental contaminants (metals and metalloids). Nevertheless, the continuing development and use of new chemicals that do not accumulate in fish and the discovery of previously unrecognized contaminants through improvements in detection methods will increase the analytical burden of existing monitoring programs. In addition, concerns about the toxic effects of exposure to low levels of many chemicals and complex chemical mixtures, and our ability to predict these effects through measurement of tissue contaminant concentrations, has led us to explore new strategies that measure biological responses for documenting exposure of fish to chemicals and determining whether exposure has been harmful to the organism. For some orgamic chemicals that are rapidly metabolized and excreted, the measurement of reactive intermediate forms bound to cellular macromolecules (DNA, RNA, and protein adducts) shows promise for documenting exposure, as does the measurement of detoxification enzyme induction. Enzyme-based methods have also been successfully employed to document exposure to environmental lead (ALA-D) and other metals (metallothioneins), and these and other biochemical endpoints have been correlated with biological responses that are significant at the wholeorganism level. Direct bioassay (in vitro, in vivo, or both) of fractionated extracts obtained from environmentally exposed fish is also a potential alternative or supplement to traditional analytical chemistry.

*Presenting author. 


\title{
A CONSTITUENT IDENTIFIER SYSTEM FOR THE NATIONAL WATER INFORMATION SYSTEM (NWIS-II)
}

\author{
James C. Schornick \\ U.S. Geological Survey \\ Water Resources Division \\ 12201 Sunrise Valley Drive, Mail Stop 412 \\ Reston, Virginia 22092
}

Stored values in the Water Resources Division data bases have historically been identified using the 5 digit Environmental Protection Agency STORET Parameter Code System. Deficiencies in the STORET Parameter Code System have prompted an effort to design an alternative for NWIS-II. The Constituent Identifier System will extend the scope of the current system by including stored data elements from all hydrologic disciplines in NWIS-II. The data can be discrete, continuous or descriptive, and the data type can be real, integer or character. Nine (9) components, plus an additional component to identify the analytical procedure used to determine the value of the constituent, form a unique combination of identifiers for each stored constituent. The ten components are: (1) Constituent Name, (2) Sampling Medium, (3) Sampling Medium Qualifier, (4) Sampling Medium Phase Qualifier, (5) Filter/Particle Size Qualifier, (6) Analyte Recovery Qualifier, (7) Field/Laboratory Qualifier, (8) Constituent Reporting Form, (9) Constituent Reporting Units, and (10) Method. Additional attributes will provide supplementary information about a given identifier and include: (1) Chemical Abstracts Systems (CAS) number, (2) the International Union of Pure and Applied Chemistry (IUPAC) chemical name, (3) trade names, (4) common names, (5) general physical/chemical category (site characteristic, sample property, nutrient, radiochemical and so forth), (6) specific physical/chemical category (weather code, calcium, alkalinity, and so forth), and (7) the equivalent EPA STORET Code. Data and/or information retrievals can use Boolean logic operations on combinations of category names.

\section{IDENTIFICATION OF THE DIFFERENCES BETWEEN ONSITE AND LABORATORY pH DETERMINATIONS USING A QUALITY-ASSURANCE PROGRAM}

\author{
LeRoy J. Schroder* \\ U.S. Geological Survey \\ Branch of Quality Assurance \\ Field Section \\ Rm. 263, Denver West III \\ Golden, Colorado 80401
}

\author{
Randolph B. See and Timothy C. Willoughby \\ U.S. Geological Survey \\ Branch of Quality Assurance \\ Acid Rain - Quality Assurance \\ Rm. 270, Denver West III \\ Golden, Colorado 80401
}

Differences between onsite and laboratory $\mathrm{pH}$ determinations reported by the National Atmospheric Deposition Program/ National Trends Network (NADP/NTN) monitoring program from 1984 through 1986 were identified by a quality-assurance program. The quality-assurance program introduces blind samples that are processed with the same onsite handling, analysis, and transportation protocols as natural samples. Laboratory $\mathrm{pH}$ deter- mination is included in the analysis of the blind sample. The median difference between onsite and laboratory hydrogen-ion determinations was $-11 \mu \mathrm{eq} / \mathrm{L}$ (microequivalents per liter) for $\mathrm{pH}$ values ranging from 4.0 to 6.0 units. These results indicate a systematic negative bias in the laboratory $\mathrm{pH}$ results reported by the NADP/NTN. This bias has at least two components. One component of about $-7 \mu \mathrm{eq} / \mathrm{L}$ that was attributed to the sampling bucket and lid was identified by the quality-assurance program. Other possible components were investigated using natural-sample data obtained from the NADP/NTN. Median differences in hydrogenion concentration between onsite and laboratory results for natural samples averaged $-4.6 \mu \mathrm{eq} / \mathrm{L}$. The bias between onsite and laboratory results was independent of sample pH. The bias was not clearly independent of sample volume.

*Presenting author. 

VALLEY, CALIFORNIA

\author{
Roy A. Schroeder*, James G. Setmire, and Jill N. Densmore \\ U.S. Geological Survey \\ 5735 Kearny Villa Road, Suite $O$ \\ San Diego, California 92123
}

The central Imperial Valley in the desert area of southeastern California contains 200,000 hectares of irrigated agricultural crops. The clay soils of the valley are underlain by 30,000 kilometers of drains, first installed more than 50 years ago. The drains carry salts from subsurface irrigation return flow and shallow ground water to ditches, or to sumps from which the water is pumped to ditches, and ultimately to the Salton Sea. Since 1942 , all irrigation to the valley has been supplied by the All-American Canal, which diverts water from the Colorado River at Imperial Dam.

Concentrations of several trace elements, including boron and selenium, were measured at more than 100 sumps by the State of California in 1986 and by the U.S. Geological Survey in 1988. No statistical differences between the 1986 and 1988 samples were found, indicating that temporal variations at a site (sump) are small except for a few days during and immediately after flood irrigation of a field. The concentrations of selenium, and other conservative ions, are determined by evaporation of Colorado River water. Thus, selenium (likely in the +6 oxidation state), which ranges from 1 to 300 micrograms perr liter, is strongly correlated $\left(\mathrm{r}^{2}=0.8\right)$ with specific conductance, which ranges from 1,500 to 45,000 microsiemens per centimeter. Mapping indicates no discernible valleywide patterns in trace-element or major-ion concentrations of the drainwater.

Tritium concentrations from 35 sumps show that Imperial Valley drainwater has a composite (closed system) age of less than 10 years and that little or no water older than 1950 enters the drains. Low correlation between selenium (also other soluble-ion) concentrations and tritium, as well as the absence of spatial patterns in drainwater chemical concentrations, is likely caused by site-to-site variations in the proportion of recently (within the last few years) applied irrigation water as compared to shallow ground water entering the drain. No simple interpretation is apparent for the contribution from each source, nor are the sources easily distinguishable by differences in their chemical composition, since both are evaporated Colorado River water.

-Presenting author.

\title{
ANALYSIS OF ORGANIC CONTAMINANTS AT THE NATIONAL WATER QUALITY LABORATORY OF THE U.S. GEOLOGICAL SURVEY II. METHODOLOGICAL IMPROVEMENTS IN SEDIMENT ANALYSES
}

\footnotetext{
Peter Schulmeyer* and Edward T. Furlong

National Water Quality Laboratory

U.S. Geological Survey 5293 Ward Road

Arvada, Colorado 80002
}

Precision, accuracy, and throughput of sediment organic analyses are limited by (1) the complexity of typical organic contaminant suites and (2) the heterogeneity of typical sediment samples. Lack of sample uniformity and extraction incompleteness are major problems, particularly with "wrist-action" shaker extraction methods.

The National Water Quality Laboratory of the U.S. Geological Survey identified and implemented methodological improvements for sediment analysis that address the problems identified above, which also reduced sample processing time. These improvements included (1) quantitatively assessed analyte recovery enhancements from addition and mixing of sodium sulfate with wet sediments, (2) the replacement of elemental mercury with activated copper in the elemental sulfur removal step, as a safety and sample processing improvement, and (3) the development of a single integrated extraction method for all sediment organic contaminants. Results for recovery studies of Base/Neutral contaminants and organochlorine insecticides are discussed within the context of validating and implementing of these improvements.

*Presenting author. 


\section{UTILITY AND LIMITATIONS OF IMMUNOASSAY TESTS AS A FIELD SCREENING METHOD FOR TRIAZINE HERBICIDES}

\author{
Peter A. Schulze and Paul D. Capel* \\ Water Resources Division \\ Minnesota District \\ St. Paul, Minnesota 55101
}

The detection and quantification of agricultural organic chemicals is a topic of concern when assessing the environmental fate, transport, and effects of these chemicals. One of the most widely used classes of compounds are the triazine herbicides, of which atrazine is commercially the most important. These chemicals are commonly found in ground, surface, and drinking waters. Two of the limitations of environmental fate studies are the long lag time between sampling and final quantification and the high cost of laboratory analysis for organic chemicals present at trace levels in environmental matrices. Field-conducted immunoassay tests have the potential to help overcome both of these limitations. The tests can be done in about 10 minutes and cost only about one-tenth the price of a laboratory analysis. Although this makes the immunoassay tests very attractive, there are significant limitations to their utility. They are intended for use only as semiquantitative screening tools. Their most useful application probably is as a presence/absence screen to determine whether a sample warrants a laboratory analysis. They also have application in guiding sampling location and frequency because they yield fast results.

A laboratory study was conducted to assess the reproducibility and detection limits of the commercially available immunoassay tests for triazine herbicides and to evaluate the effects of $\mathrm{pH}$, temperature, and concentrations of calcium, sodium, and nitrate on them. Given the typical uncertainty of 20 percent for replicate analyses, none of the environmental variables had a significant effect. The limits of detection were of the same order of magnitude as the test manufacturer's specifications. As an example, this study determined a detection limit of about 0.3 micrograms per liter for atrazine compared to the value of 0.1 micrograms per liter reported by the manufacturer.

*Presenting author.

\section{QUALITY-ASSURANCE PROGRAM FOR A PRECIPITATION-MONITORING NETWORK}

\author{
R. B. See \\ U.S. Geological Survey \\ Water Resources Division \\ Branch of Quality Assurance \\ Box 25046, Mail Stop 401 \\ Denver Federal Center \\ Lakewood, Colorado 80225
}

\author{
B. A. Malo* \\ U.S. Geological Survey \\ Water Resources Division \\ Office of Atmospheric Deposition Analysis \\ 12201 Sunrise Valley Drive \\ Reston, Virginia 22092
}

The U.S. Geological Survey has developed an external qualityassurance program for the national long-term precipitationmonitoring network: National

\section{J. Schroder and T. C. Willoughby U.S. Geological Survey \\ Water Resources Division \\ Branch of Quality Assurance \\ Box 25046, Mail Stop 401 \\ Denver Federal Center \\ Lakewood, Colorado 80225}

Atmospheric Deposition Program/National Trends Network (ADP/NTN). Several approaches are used to document the quality of data collected:
(1) The intersite-comparison program is used to assess the relative precision and bias of onsite $\mathrm{pH}$ and specific-conductance determinations. 
(2) The blind-audit program documents the effect of routine sample handling, transportation, and laboratory analyses on the bias and precision of wet-deposition data.

(3) Analytical results from laboratories that routinely analyze wet deposition sanples from the major North American networks are examined in an interlaboratory comparison program to independently determine the bias and precision of each laboratory's determinations. This independent determination assists in the use of multiple data sources for assessing spatial and temporal variations in wet deposition.

(4) Colocated sainpler studies are used to evaluate the precision of the sainple collection devices, to compare performance with collection devices used in other networks, and to assess the effect of deviations from siting protocols.
The quality-assurance procedures used by the NADP/NTN permit data users access to a qualified data set, provide an assessment of the comparability of other related databases, and enable the selection of data to meet the user's quality objectives. The NADP/NTN external quality-assurance prograin is presented as a model for an independent assessment of environmental data quality.

"Presenting author.

\section{CHLOROFLUOROCARBON COMPOUNDS IN GROUND WATER: A POSSIBLE MANAGEMENT TOOL}

Chlorofluorocarbons (CFC's) can be used to determine the relative age of ground water, that is, whether it is greater than or less than 30 years old. This information may provide a resource-management tool for municipal planning agencies, for the siting of industrial areas and landfills, for determining reasonable sampling frequencies for manmade organic compounds, and for meeting provisions of the Wellhead Protection Act. CFC's are anthropogenic gases first produced in the 1930's for use as refrigerants. Worldwide production and atmospheric release increased rapidly in the mid to late

\author{
Kathy A. Sertic \\ U.S. Geological Survey \\ Water Resources Division \\ Nevada District Office \\ Room 227, Federal Building \\ Carson City, Nevada 89701
}

1950's when industries began utilizing CFC's as aerosol propellants, foam-blowing agents, and solvents. Because of worldwide use and long tropospheric residence times (approximately 80 years for trichlorofluoromethane), atmospheric CFC concentrations have been increasing steadily since the 1950's. These increasing concentrations have been well documented since the 1970's.

CFC's partition into atmospheric - moisture, which provides recharge to ground-water systems as precipitation. Therefore, the presence of CFC's in ground water indicates that the water has been in contact with the atmosphere since the large atmospheric releases began about 30 years ago. Conversely, the absence of CFC's in ground water indicates that the water has been out of contact with the atmosphere for at least this same length of time.

Identification of ground-water zones containing young water can lead to a recognition of areas that supply ground-water recharge and are therefore susceptible to pollution from surface sources. CFC's also may allow identification of wells that do not have an adequate surface seal. 


\author{
James B. Shanley* \\ U.S. Geological Survey \\ Water Resources Division \\ 28 Lord Road \\ Marlborough, Massachusetts 01752
}

\author{
Norman E. Peters and Richard P. Hooper \\ U.S. Geological Survey \\ Water Resources Division \\ 6481-B Peachtree Industrial Boulevard \\ Doraville, Georgia 30360
}

\begin{abstract}
Soil-mediated retention of sulfate is the major neutralization mechanism of acidic deposition in the southeastern United States. At Panola Mountain, a 41-hectare forested watershed in the Georgia Piedmont, sulfate concentration at base flow varies from about 10 $\mu \mathrm{eq} / \mathrm{L}$ (microequivalents per liter) during the dry conditions of summer to about $40 \mu \mathrm{eq} / \mathrm{L}$ during the wet conditions of winter. Sulfate frequently exceeds $100 \mu \mathrm{eq} / \mathrm{L}$ during storms, however, because stormflow water has more limited contact with the mineral soil horizons that strongly retain sulfate. The interaction of stormwater with organic-rich surface soil horizons regulates sulfate in the

ephemeral headwater stream at 80 $120 \mu \mathrm{eq} / \mathrm{L}$. The higher sulfate concentration observed when water follows a more shallow flowpath is consistent with adsorption isotherms from Panola soils. The isotherms indicate strong potential for sulfate adsorption with increasing soil depth, but little or no retention in organic-rich surface horizons. In the headwater area, atmospheric sulfate is focused to thin soils and the adjacent stream channel by runoff from a bare 3hectare granite outcrop. The effect of this high sulfate loading already may have resulted in a higher steady-state sulfate concentration; a comparison of sulfate adsorption isotherms indicates
\end{abstract}

higher steady-state sulfate concentrations for soils on the outcrop side of the channel than for adjacent soils that are not in the runoff path. Although watershed soils in general have a marked tendency to adsorb sulfate, and thus neutralize acidity, the high export of sulfate at Panola Mountain during high discharge periods indicates that the retention mechanisms are not always effective. These findings challenge the prevailing hypothesis that sulfate retention may delay acidification of ecosystems in the southeastern United States indefinitely.

*Presenting author.

\section{STRATEGY FOR GROUND-WATER QUALITY ASSESSMENT OF THE DELMARVA PENINSULA, DELAWARE, MARYLAND, AND VIRGINIA}

\author{
Robert J. Shedlock*, Patrick J. Phillips, \\ and L. Joseph Bachman \\ U.S. Geological Survey \\ 208 Carroll Building \\ 8600 LaSalle Road \\ Towson, Maryland 21204
}

\author{
Pixie A. Hamilton \\ U.S. Geological Survey \\ 3600 West Broad Street, Room 606 \\ Richmond, Virginia 23230
}

The Delmarva Peninsula is one of three ground-water project areas in the U.S. Geological Survey Pilot National Water-Quality Assessment Program. The peninsula is underlain by unconsolidated sediments of the Atlantic Coastal Plain that form a complex confinedaquifer system overlain by an extensive surficial aquifer. Ground-water flow paths range in length from a few hundred feet in shallow ground water to tens of miles in the deeper aquifers. Because of differences in flow patterns, the ground-water sampling network consists of three sets of wells designed to assess spatial differences in water-quality. Wells in the first set are geographically distributed across the peninsula in the surficial and confined aquifers. Wells in the second set are along several east-west lines across the peninsula that traverse regions having different physiography, geology, and land use. Wells in the third set are along local groundwater flow paths in small watersheds in each major region. Water samples will be analyzed for a broad suite of inorganic constituents and selected organic compounds. The data from the different sets of wells will be used to relate local and regional patterns in ground-water quality to differences in geology and land use.

- Presenting author. 


\author{
Larry R. Shelton \\ U.S. Geological Survey \\ California District Office \\ 2800 Cottage Way \\ Sacramento, California 95825
}

The California District is presently working with the Methods Research and Development Program of the National Water Quality Laboratory to improve the equipment and procedures used to collect water samples for analyses of organic contaminants. During a special study of the San Joaquin River, two modifications were made to the $D$ 77 water sampler. One modification uses a rigid Teflon bottle to replace the original Nalgene bottle; the other uses a collapsible Teflon bag inside the bottle. Both modifications to the D-77 use a special machined Teflon head and nozzle. These also can be used on a modified DH-75 that accommodates a glass bottle. Samples are composited and split into subsamples using a "Cone Splitter" made of stainless steel, Teflon, and glass. Stainless steel filtration equipment, glass fiber filters, Teflon tubing and other modifications to the equipment and procedures have been developed and introduced for use in sampling to avoid contaminating organic samples.

\title{
THE ROLE OF SUBMARINE GROUNDWATER DISCHARGE TO NUTRIENT FLUX IN COASTAL AND OCEANIC ENVIRONMENTS
}

\author{
George M. Simmons, Jr. \\ Biology Department \\ Virginia Polytechnic Institute and State University \\ Blacksburg, Virginia 24061
}

The movement of water across sediment/water interfaces is a very important ecological property in aquatic habitats. This type of water influx is referred to as Submarine Groundwater Discharge (SGWD). The movement of SGWD is primarily by advective flow and may be due to a variety of factors. In nearshore marine environments, the major factor is probably due to groundwater flow from upland regions. In oceanic environments, the influx of SGWD is probably influenced more by tides and surge action. SGWD, therefore, may represent a mixture of fresh groundwater and seawater, or be primarily seawater that is cycling through marine sediments.

This type of coupling between land/water habitats and between sediments and pelagic environments has often been overlooked. In addition, the magnitude of SGWD and its role in the transport of dissolved compounds also seems to be generally unrecognized. However, the process seems to be so pervasive that many ecological problems may have been misinterpreted due to a lack of understanding of the role that SGWD plays in recycling dissolved compounds from the sediments.

The purpose of this paper is to summarize the importance of SGWD in shallow estuarine, continental shelf, and coral reef habitats. The relationship between agricultural practices, human population growth, vegetation barriers, and the magnitude of SGWD are such that the role of SGWD on receiving water quality deserves consideration in any water quality plan. 


\begin{tabular}{l} 
THE RELATION OF TOXICITYTEST RESULTS TO PHASE ASSOCIATION \\
AND CONCENTRATION OF CHROMIUM, MANGANESE, IRON AND \\
AMMONIUM IN THE WATER COLUMN AND SEDIMENTS OF AN \\
INDUSTRIALLY AFFECTED AREA OF THE CALCASIEU RIVER, LOUISIANA \\
\hline
\end{tabular}

\author{
N. S. Simon \\ Mail Stop 432 \\ Branch of Regional Research, NR \\ U.S. Geological Survey \\ 12201 Sunrise Valley Drive \\ Reston, Virginia 22092
}

The U.S. Geological Survey and the U.S. Environmental Protection Agency began a cooperative field and laboratory study of Bayou d'Inde in June 1988. Bayou d'Inde, which receives effluent from industrial outfalls, discharges into the Calcasieu River, Louisiana. Samples of bottom sediment and water-column water were collected simultaneously. Toxicity tests of water-column water and bottom material were done by the U.S. Environmental Protection Agency. The U.S. Geological Survey was responsible for water-quality analyses of water-column samples and for determining total metal concentrations in the water column and for recoverable-metals analyses of sediment samples. Adsorbed ammonium analyses also were done on sediment samples. Water-column and interstitial-water samples were analyzed for ammonium, chloride, sulfate, iron, manganese, chromium and lead concentrations. The effect of particulate size on metal concentrations in watercolumn samples was determined by filtering an aliquot of each watercolumn sample through successively smaller membrane pore-sizes and through an ultrafilter at the field site in preparation for laboratory analyses for manganese, iron, chromium, and lead concentrations. Pore sizes included $0.45,0.2$, and 0.1 micrometers.

None of the water-column samples were reported to be toxic. Colloidal iron in the water column appeared to contribute to the transport of chromium. A combination of water-column and sediment data was needed to demonstrate the effect of industrial input to the study area. Sediment toxicity was localized and coincided with a combination of factors that included (1) high dissolved manganese concentrations in the water column, high rates of sediment sulfate reduction, plus elevated interstitial-water $\mathrm{pH}$ and concentrations of ammonium with high concentrations of adsorbed ammonium on the associated sediment, and (2) an increase in the interstitial-water concentrations of chloride and a decrease in watercolumn concentrations of dissolved manganese compared with those of upstream sites, plus low watercolumn concentrations of chromium and lead.

\title{
RELATING GROUND-WATER QUALITY TO LAND USE: CONSIDERATIONS OF SCALE AND DATA RESOLUTION
}

\author{
Steven F. Siwiec* and Paul E. Stackelberg \\ U.S. Geological Survey \\ Water Resources Division \\ 5 Aerial Way \\ Syosset, New York 11791
}

Logistic regression is a technique to model a maximum-likelihood categorical response from one or more continuous explanatory variables. In a logistic-regression equation, the slope associated with each explanatory variable is an indicator of the sensitivity of the response to changes in the explanatory variable.

Two logistic-regression models were fitted to one set of binary data indicating the presence or absence of volatile organic compounds at 90 observation wells screened in the shallow unconfined (water-table) aquifer on Long Island, N.Y. Two explanatory variables were used in the models: (1) percentage of commercial/industrial land within a 1/2-mile radius of each sampled well, and (2) percentage of residential land within the same area. Models were fitted by identical 
methods, using land-use data from two sources compiled at different scales. Although both models were significant at $p=0.01$ and exhibited similar intercepts, landuse data compiled at $1: 250,000$ scale yielded a higher slope for the residential variable and data compiled at 1:24,000 scale yielded a higher slope for the commercial/industrial variable.

Comparison of digital land-use data in three 7.5-minute quad- rangles exhibiting a representative range of land uses indicates that the 1:250,000-scale data consistently show more (5 to 8 percent) residential land area and less (5 to 8 percent) commercial/industrial land area than the 1:24,000-scale data. Spatial overlay of these land-use data, through the use of a geographic information system, shows that most of this difference is attributable to the residential classification of small (less than
4 hectares) parcels of commercial/industrial land interspersed in residential areas, which are not resolvable at the $1: 250,000$ scale. The generalization of these unresolvable land-use polygons accounts for the majority of the observed difference in slopes between the land-use variables in the two logistic-regression equations.

*Presenting author.

\title{
INVERTEBRATE DRIFT AS A BIOLOGICAL INDICATOR OF WATER QUALITY
}

\author{
Keith V. Slack*, Larry J. Tilley, and Susan S. Kennelly \\ U.S. Geological Survey \\ Branch of Regional Research, Western Region \\ Menlo Park, California 94025
}

Stream organisms are useful indicators of water quality and effects of human impacts because of their prolonged exposure, integrated response, and differing sensitivities to environmental conditions. Benthic invertebrates are most commonly used for this purpose because they exhibit a range of life spans and vary in sensitivities and recovery rates following impacts. Under many conditions, streambed sampling of the benthos is difficult, but the tendency of most stream species to drift downstream in the water column provides an alternative method of sampling. Drift sampling uses inexpensive nets, produces samples of high species diversity, and requires little specialized training. Various factors influence drift, but many studies show a strong similarity between drift and benthos. Drift density (numbers per cubic meter) increases in response to environmental impacts because drift is a mechanism by which benthic species escape unfavorable conditions.

To examine drift in Colorado Rocky Mountaim streams of contrasting water quality, samples were collected upstream and downstream from the confluence of Deer Creek (circumneutral pH) and Snake River (low pH, metal enriched). Above the confluence, mean drift densities and numbers of taxa were for Deer Creek, 114.8 per cubic meter, 97 taxa, and for Snake River, 18.5 per cubic meter, 39 taxa. Below the confluence at intermediate conditions of water quality, these values were 50.7 per cubic meter, 81 taxa. Therefore, the effect of the acid stream was to decrease drift density and species abundance in the combined stream below the confluence. Similar results were obtamed for the benthic community at these sites using dip net samples which required more effort to collect.

*Presenting author. 


\author{
R. A. Smith* and R. B. Alexander \\ U.S. Geological Survey \\ Water Resources Division \\ 12201 Sunrise Valley Drive \\ Reston, Virginia 22092
}

\author{
D. A. White and K. F. Lins \\ U.S. Geological Survey \\ National Mapping Division \\ 12201 Sunrise Valley Drive \\ Reston, Virginia 22092
}

\author{
K. W. Robinson and C. V. Price \\ U.S. Geological Survey \\ Water Resources Division \\ 810 Bear Tavern Road, Suite 206 \\ W. Trenton, New Jersey 08628 \\ S. K. Jenson \\ U.S. Geological Survey \\ National Mapping Division \\ Sioux Falls, South Dakota 57102
}

\begin{abstract}
Recent changes in the Federal Clean Water Act (PL 100-4) require State governments to conduct a variety of statewide assessments of water-quality. One major difficulty with assessment at this scale is that water-quality data are collected at sampling locations that are not statistically representative of statewide conditions. State officials must extrapolate waterquality conditions beyond the sampled locations in attempting to estimate the fraction of total stream miles that meet established criteria. Currently, the methods for accomplishing this extrapolation are highly subjective in nature and variable from State to State.
\end{abstract}

A U.S. Geological Survey research project is underway to develop an objective and nationally consistent methodology for statewide water-quality assessment using the State of New Jersey as a prototype. Regression techniques are used to correlate a variety of water-quality measures with spatially detailed information on land use and pollution sources (both point and nonpoint) within the State. Ambient water-quality data and pollutant loading rates for individual municipal and industrial point sources are provided by the New Jersey Department of Environmental Protection. Information for estimating nonpointsource pollutant loads are derived from spatially detailed population data and digital land use/land cover data. Land use/land cover classification is based on existing 1973 coverages updated to represent
1985 conditions through use of Landsat Thematic Mapper data. Overland flow paths and channel networks are identified through analysis of digital elevation data.

Once constructed, the regression model is applied to a large and representative sample of stream reaches to obtain unbiased statewide estimates of water quality conditions. A potential additional use of the methodology developed in this project would be regionalizing water-quality information within large basins, such as study areas in the National Water Quality Assessment Prograin.

*Presenting author. 


\section{USE OF MULTIVARIATE TECHNIQUES FOR BACKGROUND AND ANTHROPOGENIC-SOURCE ANALYSIS OF TRACE ELEMENTS IN STREAMBED MATERIALS IN THE UPPER ILLINOIS RIVER BASIN IN ILLINOIS, INDIANA, AND WISCONSIN}

\author{
Steven M. Smith and Richard F. Sanzolone \\ U.S. Geological Survey \\ Geologic Division \\ Branch of Geochemistry \\ Mail Stop 973 \\ Box 25046 Federal Center \\ Denver, Colorado 80225
}

\author{
John A. Colınan* \\ U.S. Geological Survey \\ Water Resources Division \\ 102 E. Main, 4th Floor \\ Urbana, Ilinois 61801
}

The upper Illinois River basin is one of four areas selected to test and refine concepts for the surfacewater phase of a National WaterQuality Assessment Program. Land use in the 10,000-square-mile basin is dominated by agriculture and the Chicago metropolitan area. Multivariate techniques were applied in one assessment objective--a synoptic survey of streambed materials to define the occurrence and distribution of trace elements in the basin.

Forty-three elements were measured in the silt-clay fraction of streambed materials collected from 432 randomly selected sites. Two thirds of the sites were on selected low-order streams for use in characterizing background conditions throughout the basin; the remainder were on the mainstems of rivers to characterize river-reach distributions and the effects of point sources on sediment quality. "R-mode" factor analysis was used to reduce the two data sets into significant element associations or factors. A comparison was made of factor-determined background sites with sites selected in low- population areas upstream from known point-source discharges. The feasibility of mapping background concentrations across the basin was investigated.

A strong anthropogenic influence was identified in each data set. Characterization of anthropogenic sources was investigated by factorscore/element-concentration plots, outlier-site mapping, and additional factor analysis of selected anthropogenic elements.

*Presenting author.

\section{EFFECT OF FLOW CONDITIONS ON STREAM REAERATION COEFFICIENTS}

\author{
James L. Smoot \\ U.S. Geological Survey \\ Kentucky District \\ 2301 Bradley Avenue \\ Louisville, Kentucky 40217
}

As flow changes in streams; the hydraulic properties which control the process of oxygen transfer between the water surface and the atmosphere (reaeration) change. Decreasing flow generally causes the stream depth and velocity to decrease. The effect on the firstorder rate coefficient (reaeration coefficient) from these types of changes can be either an increase or decrease, the direction and magnitude of which is stream-type, and possibly site, specific.
Hydraulic and reaerationcoefficient measurements were made on four reaches of the Middle Fork Beargrass Creek in Louisville, Kentucky. Measurements were made using the hydrocarbon gas tracer technique during seven different flow conditions. The reaeration coefficient decreased with decreasing flow in all four reaches. In the reach with the largest overall energy gradient, the reaeration coefficient under low-flow conditions dropped to only 14 percent of its medium-flow value. The other three reaches also had significant decreases in their reaeration coefficients under low-flow conditions to about 40 percent of their medium-flow values. These results suggest that dissolved-oxygen models developed using reaeration coefficients determined during flow conditions higher than the modeled condition would overpredict stream dissolved-oxygen concentrations. 
Two regression-based prediction equations were developed which provided more accurate estimates of the reaeration coefficients for the studied reaches than any of 25 selected equations from the literature. The two equations were also shown to be more accurate than the literature equations when used with data from 39 hydrocarbon gas tracer measurements made on other streams. This verification analysis showed average prediction errors for both the equations of less than 6 percent.

To develop accurate dissolvedoxygen models, reaeration coefficients are best determined for flow conditions close to those to be modeled. Because of the difficulties in determining reach-averaged hydraulic parameters and the inherent error in applying prediction equations, measured reaeration coefficients are generally more desirable than those estimated from equations.

\section{DEPARTMENT OF INTERIOR IRRIGATION DRAINAGE PROGRAM RECONNAISSANCE STUDY OF KLAMATH BASIN REFUGE AREAS, CALIFORNIA AND OREGON}

\author{
Stephen K. Sorenson* \\ U.S. Geological Survey \\ California District Office \\ 2800 Cottage Way \\ Sacramento, California 95825
}

\author{
S.E. Schwarzbach \\ U.S. Fish and Wildlife Service \\ 2800 Cottage Way \\ Sacramento, California 95825
}

Contamination of wildlife refuges with naturally occurring toxic elements and manmade chemicals associated with agricultural practices has become an increasing concern in recent years. The objective of this reconnaissance study was to determine whether irrigation drainage waters in the Lower Klamath Lake and Tule Lake National Wildlife Refuge areas have caused or have the potential to cause harmful effects on human health, fish and wildlife, or other beneficial uses of the water.

Samples of water; bed sediments; eggs and tissues from mallards, western grebes, and coots; benthic and nektonic invertebrates; fish; and aquatic plants were collected once during the summer of 1988 at various locations including points above and below the sources of irrigation return flows. Water samples were analyzed for major ions and selected dissolved trace constituents. Bed sediments and biological tissues were analyzed for trace constituents and organochlorine compounds.

Ionic composition of water shifted from mixed cation bicarbonate type to sodium sulfate type as the water moved through the irrigation system and accumulated return flows. One water sample in Lower Klamath Lake Refuge had an arsenic concentration (63 micrograms per liter) exceeding State and Federal drinking-water standards. No other standards or criteria were exceeded in water samples from any of the sampling locations. Bed-material samples contained no trace constituents that exceeded existing or proposed State or Federal criteria. Detectable quantities of organochlorine compounds were found in 10 of the 12 bed-material samples; DDE was the most frequently detected compound.

Mercury concentrations in mallard eggs and total organochlorine concentrations in western grebe eggs were high enough to be of concern for the nesting success of these birds. Analyses of most biological tissue samples have not been completed.

-Presenting author. 


\author{
Timothy B. Spruill \\ U.S. Geological Survey \\ 4821 Quail Crest Place \\ Lawrence, Kansas 66049
}

residual saturation in aquifer sediments underlying the site. Although naphthalene and phenanthrene compounds have relatively small octanol to water partition coefficients, and watersolubility values of as much as $\mathbf{3 0}$ milligrams per liter, these compounds are believed to be biodegraded or sorbed as they move with the water through the alluvial-aquifer sediments. This hypothesis is supported by data showing that dissolved concentrations of polynuclear aromatic compounds in ground water in the vicinity of the contaminated sediments are as much as 200 micrograms per liter; in water collected from wells located a few hundred feet downgradient from the oil-contaminated aquifer sediments, concentrations are 3 micrograms per liter, or less.

\section{HERBICIDES IN SURFACE AND GROUND WATER, CEDAR RIVER BASIN, IOWA AND MINNESOTA}

\author{
Paul J. Squillace* \\ U.S. Geological Survey \\ P.O. Box 1230 \\ Federal Building, Room 269 \\ 400 South Clinton Street \\ Iowa City, Iowa 52244-1230
}

\author{
Mark W. Sandstrom \\ U.S. Geological Survey \\ National Water Quality Laboratory \\ 5293 Ward Road \\ Arvada, Colorado 80002
}

\author{
Wilfred E. Pereira \\ U.S. Geological Survey \\ P.O. Box 25046, Mail Stop 408 \\ Denver, Colorado 80225
}

Concentrations of alachlor, atrazine, cyanazine, metolachlor, metribuzin, propazine, and simazine were monitored from April through July 1988 at seven surface-water sites in subbasins ( 777 to 15,500 square kilometers) of the Cedar River drainage basin in Iowa and Minnesota. Concentrations of herbicides ranged from $<0.1$ to 10.0 micrograms per liter. A seepage run was conducted on the Cedar River and its tributaries during the study. Streams returning to base-flow conditions following storm runoff contained larger concentrations of herbicides than streams that received no storm runoff. The larger concentrations at sites in smaller subbasins may be attributed to discharge from field drainage-tile systems into the streams. At sites on large tributaries and along the mainstem of the Cedar River, the larger concentrations may be caused by the drainage of bank storage or drainage from alluvial aquifers.

Four well nests of three wells each were completed in the alluvium in an unfarmed area along the mainstem of the Cedar River. The well nests were located 10 to 80 meters from the river, and the wells at each nest ranged from 3 to 10 meters deep. Atrazine, cyanazine, metolachlor, and two degradation products of atrazine, desethylatrazine and desisopropylatrazine, were detected in water samples from the alluvial wells. Concentrations ranged from 0.01 to 0.40 micrograms per liter. Generally, the concentrations decreased with distance from the river. Water samples were also collected from 3 wells, 2 of which are known to be domestic. The wells were 20 to 53 meters deep and 10 to 300 meters from the alluvium. Water levels 
could be measured in only one of the bedrock wells and was determined to be higher than in the alluvial wells. Concentrations of atrazine, desethylatrazine, and desisopropylatrazine ranged from 0.01 to 0.30 micrograms per liter. The alluvial aquifer may receive recharge (and herbicides) from the river and the area adjacent to the alluvium.

*Presenting author.

\title{
SETTLING PROPERTIES OF SUSPENDED SEDIMENT FROM THE MISSISSIPPI RIVER
}

\author{
Robert F. Stallard* and Deborah A. Martin \\ U.S. Geological Survey \\ Box 25046, MS 413, Denver Federal Center \\ Lakewood, Colorado 80225
}

Suspended sediment in rivers is deposited when the velocity and turbulence of the river are decreased. The state of aggregation affects the settling properties of the sediment and, therefore, may affect the composition of sediment that is deposited.

The pipet method was used to determine the effective sizefrequency distribution of suspended sediment from the Mississippi River. Samples were collected during the U.S.
Geological Survey Mississippi River Project at 5 meters depth at well-mixed cross sections at midflow by using a horizontal Van Dorn bottle. Preliminary results indicate that the suspension settles as if it were primarily composed of particles larger than 2 microns. When the suspended sediment is chemically and ultrasonically dispersed, at least 25 percent of the particles are finer than 2 microns. These results indicate that much of the fine-particle fraction is incorporated into rapidly settling aggregates. Such aggregates would be deposited on a time scale of several days if the flow of the river were stopped. Comparison of these results with samples collected by using depth-integrating samplers indicate that methods of sampling and processing that involve sieving and agitation are likely to partially disrupt these aggregates.

*Presenting author.

\section{USING A GEOGRAPHIC INFORMATION SYSTEM TO RELATE HUMAN AND NATURAL FACTORS TO STREAM WATER QUALITY IN THE UPPER ILLINOIS RIVER BASIN IN ILLINOIS, INDIANA, AND WISCONSIN}

\author{
Faith A. Stanke \\ U.S. Geological Survey \\ Water Resources Division \\ 102 East Main Street, 4th Floor \\ Urbana, Illinois 61801
}

\begin{abstract}
A geographic information system (GIS) provided a convenient and practical tool for automating the processes of storing, managing, and analyzing a variety of waterquality and ancillary data for the National Water Quality Assessment (NAWQA) pilot study of the upper Illinois River basin. The GIS was beneficial in temporal and spatial analysis of water-quality data and helped relate current
\end{abstract}

conditions and data trends to causative factors such as land cover, land-use practices, population, point-source discharge sites, atmospheric deposition, soils, and geology. The GIS also was valuable for displaying interrelations among water-quality data and causative factors in river basins and at specific data-collection sites. Custom command macros, designed in the computer interface, allowed retrieval and analysis of the data by a non-expert with little knowledge of the GIS. Publicationquality displays of any part of the data set were easily generated. The GIS have improved the access, use, and analysis of extensive temporal and spatial data sets and reduced personnel and analysis costs. 


\title{
SIMULATION OF THE CHEMICAL EVOLUTION OF A PLUME OF ACIDIC GROUND WATER
}

\author{
K. G. Stollenwerk \\ U.S. Geological Survey \\ Water Resources Division \\ P.O. Box 25046, MS 413 \\ Denver, Colorado 80225
}

The geochemical model PHREEQE was used to help identify a set of solid phases that could be used to simulate the chemical evolution of a contaminant plume of acidic ground water near Globe, Arizona. Simulation began in the most acidic part of the plume, where $\mathrm{pH}$ was 3.63 , specific conductance was $10,400 \mu \mathrm{S} / \mathrm{cm}$ (microsiemens per centimeter), and concentration of dissolved metals was greater than $3,000 \mathrm{mg} / \mathrm{L}$ (milligrams per liter); simulation ended 12 kilometers downgradient where pH was 6.16 , specific conductance was $3,470 \mu \mathrm{S} / \mathrm{cm}$ and concentration of dissolved metals was less than $50 \mathrm{mg} / \mathrm{L}$. The changes in concentrations of chloride, sulfate, silica, sodium, calcium, magnesium, iron, aluminum, copper, cobalt, nickel, zinc, dissolved oxygen, $\mathrm{pH}$, and $\mathrm{pE}$, were simulated at 18 sites along the ground- water flow path where water chemistry was analyzed.

In the aquifer, the concentrations of constituents in the acidic plume were modified by an unknown amount of dilution with ground water from other sources and by chemical reactions. To account for dilution in each of the eighteen simulations, chloride was assumed to be nonreactive; measured concentrations of chloride in the aquifer were then used to estimate the volume of uncontaminated ground water that was needed to mix with the plume. Ferrous iron [Fe(II)] was oxidized to ferric iron [Fe(III)] by adding dissolved oxygen in the dilution step of each simulation. Calcite, the most reactive solid phase in alluvium unaffected by the plume, was added to each simulation to neutralize hydrogen ions.
Equilibrium was assumed in all precipitation-dissolution reactions. The solid phases used by the geochemical model PHREEQE to control solution concentrations were gypsum $\left(\mathrm{CaSO}_{4}{ }^{\mathrm{n}} 2 \mathrm{H}_{2} \mathrm{O}\right)$, amorphous ferric hydroxide $\left[\mathrm{Fe}(\mathrm{OH})_{3}\right]$, basic aluminum sulfate $\left(\mathrm{A} 1 \mathrm{OHSO}_{4}\right)$, gibbsite $\left[\mathrm{A1}(\mathrm{OH})_{3}\right]$, and silica gel $\left(\mathrm{SiO}_{2}\right)$. Copper, cobalt, nickel, and zinc were assumed to either adsorb or coprecipitate with $\mathrm{Fe}(\mathrm{OH})_{3}$. Nonlinear adsorption constants for all four metals were determined empirically from ground-water analyses. Most of the change in concentration of magnesium and sodium could be accounted for by dilution. The simulated concentrations of all 15 constituents were within ten percent of the analytical concentrations for each site.

\section{DEVELOPMENT OF SURFACE WATER QUALITY STANDARDS FOR TOXIC SUBSTANCES "THE WISCONSIN EXPERIENCE"}

\author{
John R. Sullivan \\ Wisconsin Department of Natural Resources \\ $\mathrm{WR} / 2$ \\ P.O. Box 7921 \\ Madison, Wisconsin 53707
}

As part of the requirements of the 1987 amendments to the Clean Water Act, all states in the nation are required to adopt surface water quality standards for toxic substances. The State of Wisconsin is one of the first states to adopt standards under these requirements. These rules which set standards for protection of fish and aquatic life, wildlife, and humans were in the making since 1984 and became state law on March 1, 1989. The development of these standards was not without controversy and great scientific debate, in fact, certain issues are still being discussed today in Wisconsin and other states.

Numerical standards have been established for about 100 toxic pollutants including polychlorinated biphenyls (PCBs), mercury, 2,3,7,8-tetrachlorodibenzo-p-dioxin, and pesticides such as DDT. Standards for each contaminant listed in the rule are based on equations which calculate at what level a substance becomes (1) acutely toxic to fish and aquatic life; (2) chronically toxic to fish and aquatic life; (3) toxic to wildlife and domestic animals; (4) toxic to humans but 
not carcinogenic; and (5) cancercausing in humans.

The standards are based on national guidance and procedures but tailored to Wisconsin when state-specific data rather than national averages are available.

The major use of these standards will be to regulate, when necessary, the discharge of toxic substances into state waters. The implementation of these rules has led to a tremendous need for the gathering of water quality data for many previously unmonitored substances.

\title{
RESULT OF A WATER QUALITY MONITORING AND MODELING PROGRAM FOR THE PATUXENT RIVER BASIN MARYLAND
}

\author{
Robert M. Summers \\ Maryland Department of the Environment \\ Water Management Administration \\ 2500 Broening Highway \\ Baltimore, Maryland 21224
}

Since 1985, the Maryland Department of the Environment and the Maryland District of the U.S. Geological Survey have been conducting a comprehensive evaluation of point and nonpoint source nutrient and sediment pollution in the Patuxent River Basin, a major western shore tributary of the Chesapeake Bay. The watershed includes both freshwater and estuarine environments and provides an opportunity to evaluate a wide range of water quality problems and management solutions being considered for the State of Maryland, and the Chesapeake Bay.
A major component of the evaluation effort is an extensive water quality monitoring program with emphasis on quantifying nutrient and sediment loading from different parts of the watershed to the Patuxent Estuary. Discharge and water quality measurements are being made at stations representing 6 different sub-watersheds, ranging in size from 5 to 340 square miles. In addition, 7 single land use agricultural field sites are being monitored to characterize the water quality impacts of major agricultural practices, and the benefits of control measures being taken by farmers in the watershed.
Water quality data from this program, similar data from other sources, and related geographic information is being incorporated into a comprehensive computer model of hydrologic and water quality (nutrient and sediment) processes in the watershed. Although the model is not yet complete, much of the montioring and related data has been analyzed. Results of this analysis will be presented, including the application of a multiple regression based technique to estimate river-borne nutrient loads.

\section{POTENTIAL USE OF CONSTRUCTED WETLANDS TO TREAT LANDFILL LEACHATE}

\author{
Jan M. Surface* \\ U.S. Geological Survey \\ Water Resources Division \\ New York District \\ $521 \mathrm{~W}$. Seneca Street \\ Ithaca, New York 14850 \\ John H. Peverly and Robert J. Kopka \\ Cornell University \\ Agronomy Department \\ Bradfield Hall \\ Ithaca, New York 14853
}

\author{
Tammo S. Steenhuis and William E. Sanford \\ Cornell University \\ Agricultural and Biological Engineering Department \\ Riley Robb Hall \\ Ithaca, New York 14853
}

Mitchell J. Lavine

Tompkins County Department of Planning

301 Harris B Dates Drive

Ithaca, New York 14850
Surface- and ground-water contamination from municipal solid-waste-landfill leachate has led to stringent regulations that require landfills be lined and equipped with leachate collection and treatment systems. Constructed wetlands, shown to be successful in the renovation of 
domestic wastewater and mine dramage, are being investigated in New York State as a method of landfill-leachate treatment. Four experimental wetland plots, which incorporate a rock-reed-filter system, have been constructed at a municipal solid-waste landfill in Tompkins County, New York. The plots are trapezoidal (11-feet top width, 115-feet long, and 2-feet deep) and each has a different substrate material (1-inch stone, pea gravel, and sand/0.5-inch stone mix), hydraulic loading, and planting (Phragmites communis or bare). The slopes of the beds are 0.5 percent. The objective of the study is to evaluate the efficiency of leachate treatment as a function of substrate material, plant growth, leachate quality, and seasonal climatic variability and to identify those design and operating characteristics that would optimize landfill-leachate treatment in a constructed wetland.

Presenting author.

\title{
EVALUATION OF A MODIFIED COMMERCIAL AUTOMATIC SAMPLER FOR THE COLLECTION OF WATER SAMPLES CONTAINING TRACE ORGANICS
}

\author{
D.Y. Tai* \\ U.S. Geological Survey \\ Hydrologic Instrumentation Facility \\ Building 2101, \\ Stennis Space Center, Mississippi 39529 \\ Kevin D. White \\ U.S. Geological Survey \\ 2301 Bradley Avenue \\ Louisville, Kentucky 40217
}

\author{
Marshall E. Jennings \\ U.S. Geological Survey \\ 8011 Cameron Rd. \\ Building 1, \\ Austin, Texas 78753 \\ L.A. Garcia \\ U.S. Geological Survey \\ Hydrologic Instrumentation Facility \\ Building 2101 \\ Stennis Space Center, Mississippi 39529
}

A commercial organic automatic sampler, which collects 24 separate sequential samples at a sample size of $\mathbf{3 5 0}$ milliliters in glass bottles or 1,000 milliliters in polypropylene bottles, was evaluated. This sampler was modified to collect samples up to 1,000 milliliters in glass bottles for the analyses of trace organics in water. The design of the modification is presented. The measured peristaltic pump suction head lift of the sampler was 17.5 feet with a loss of 50 percent of its capacity at 21 feet of head.

The possible absorption or adsorption of organics on the distribution line, silicon tubing, as well as the Teflon suction line were tested. The efficiency of the cleaning cycle of the post air purge between samples has also been evaluated. The initial results for atrazine indicated that there was no significant adsorption on the system line. There was a slight carry-over of the test solution between sampling cycles due to the inefficiency of the air purge for the cleaning cycle. The compounds used for testing were atrazine and chlorophenol. The test results are presented.

"Presenting author.

\section{OCCURRENCE AND DISTRIBUTION OF TRACE METALS IN THE MISSISSIPPI RIVER}

\author{
Howard E. Taylor*, John R. Garbarino, and Terry I. Brinton \\ U.S. Geological Survey \\ Water Resources Division \\ 5293 Ward Road, Mail Stop 408 \\ Arvada, Colorado 80002-1811
}

The temporal and spatial distribution of trace metals in the Mississippi River and its major tributaries has been determined by systematic depth-integrated sampling and a variety of analytical techniques including: inductively coupled plasma-optical emission, inductively coupled plasma-mass, and atomic absorption spectrometry. During a three year period, a Lagrangian strategy was 
used to sample the Upper Mississippi, Illinois, Missouri, Ohio, and Arkansas Rivers and the main stem of the Mississippi River to downstream of New Orleans, Louisiana under a variety of hydrologic conditions. Trace metals were measured in the dissolved phase, and in the suspended sediments (silt and clay-size fractions). Two types of analyses were performed: 1) semiquantitative to provide reconnaissance for unusual trace metals, and 2) quantitative to determine concentrations of aluminim, arsenic, barium, beryllium, cadmium, cobalt, chromium, copper, iron, lithium, manganese, molybdenum, lead, strontium, thallium, uranium, vanadium, and zinc suitable for performing mass balance, load, and correlation calculations. Loadings are conservative for most metals and sampling precision is less than 0.5 percent.

*Presenting author.

\section{BIOLOGICAL MONITORING OF STREAMS IN JEFFERSON COUNTY, KENTUCKY}

\author{
Jerry Terhune \\ Louisville and Jefferson County \\ Metropolitan Sewer District \\ 4522 Algonquin Parkway \\ Louisville, Kentucky 40211
}

In 1988 , utilizing funds received jointly from the Louisville and Jefferson County MSD and Virginia Environmental Endowment, a study of streams in Jefferson County, Kentucky was initiated. The principal objectives of the study were to develop a methodology for biological monitoring of streams in urban areas and to develop a Biological Index that would indicate stream quality given the diverse nature of streams within the county.

Twenty-six stations were selected representative of all seven water basins within Jefferson County. Kick, grab and various artificial subtrate samplers were utilized and compared. Based on the results of our initial sampling, brick artificial subtrate samplers were selected. Multiplate, basket subtrates were also evaluated but bricks were chosen on the basis of efficiency and cost.

Based on previous studies and our initial sampling, a species list was developed for macroinvertebrates found in streams in Jefferson County. Previous research was used to categorize organisms into one of three groups: Tolerant, Facultative and Intolerant. Organisms were keyed to the lowest taxonomic level possible given the limitations of time and completeness of keys available.

During the initial sampling phases from January 1988 to January 1989 , over 50,000 macroinvertebrates were collected and identified. In addition, 38 different physical and chemical parameters were monitored every 2 weeks at each station.

The sampling is continuing through the Fall of 1989 and the final results will be presented in this paper. We expect to collect and identify over 80,000 macroinvertebrates, making this one of the most thorough studies done to date.

\section{OCCURRENCE AND DISTRIBUTION OF NUTRIENTS AND DISSOLVED}

OXYGEN IN THE UPPER ILLINOIS RIVER BASIN IN ILLINOIS, INDIANA, AND WISCONSIN: RESULTS OF A 1988 LOW-FLOW SYNOPTIC SURVEY

\author{
Paul J. Terrio \\ U.S. Geological Survey \\ Water Resources Division \\ Illinois District \\ 102 East Main Street, 4th Floor \\ Urbana, Illinois 61801
}

A low-flow synoptic survey of nutrients and dissolved oxygen (DO) was performed from July 26 to August 4, 1988, by the U.S.
Geological Survey, as part of the upper Illinois River basin National Water-Quality Assessment pilot study. The purpose of the survey was to assess the concentrations and areal distributions of the targeted parameters during a period of low flow and high temperature 
when DO concentrations were reduced. Approximately 60 sites were sampled including fixed stations, sites on major streains ensuring a resolution of at least 50 river miles, and randomly selected sites stratified by land use. Sainples were collected between 4 a.m. and 8 a.m., the interval of lowest DO concentration. Several sites were also sampled hourly during a 24-hour period to confirm the diurnal variation in DO.
Concentrations of dissolved nitrite plus nitrate ranged from 0.1 to $15.0 \mathrm{mg} / \mathrm{L}$ (milligrams per liter), with a median of $1.1 \mathrm{mg} / \mathrm{L}$. Concentrations generally were higher in the Des Plaines River basin, which receives effluents from numerous sewage treatment plants, than in other basins. Comparatively low concentrations (median concentration of 0.19 $\mathrm{mg} / \mathrm{L}$ ) were found in the Kankakee River basin.
DO concentrations ranged from 1.85 to $11.1 \mathrm{mg} / \mathrm{L}$, with a median of $6.7 \mathrm{mg} / \mathrm{L}$. Concentrations of DO were lowest in the Des Plaines and Kankakee River basins. The low concentrations in the Kankakee River, the cleanest river in Illinois, were not expected and were probably caused by the severe drought, which caused a depletion of the DO in the available water. Approximately 30 percent of the sites had DO concentrations below the State water-quality criterion.

\section{ENHANCEMENT OF A HYDROLOGIC BENCH-MARK NETWORK SITE}

\author{
John T. Turk \\ U.S. Geological Survey \\ Building 53, Mail Stop 415 \\ Denver Federal Center \\ Lakewood, Colorado 80225
}

Analysis of the water quality records collected for 10 to 15 years from the Hydrologic Bench-Mark Network indicates that many streams in the western United States have trends of decreasing pH and alkalinity consistent with acidification of surface water by acid precipitation. However, no ancillary data necessary to test this, or any, hypothesis regarding the cause of present or future trends in surface-water flow or quality are collected at most network sites. If the network is to be useful for detecting and explaining trends, monitoring of climate, atmospheric deposition, and changes in watershed characteristics will be needed. Research will be needed to determine the controls on flow and water quality.

The site on Halfmoon Creek near Malta, Colorado was chosen to demonstrate the mutual benefit of long-term monitoring and of research on watershed processes at the same site. Research will be used to identify causes of trends in surface-water chemistry. The previous detection of trends by traditional network monitoring ensures that measureable changes in watershed characteristics or processes must exist.

\section{SOURCES OF ERROR IN FIELD SPECIFIC-CONDUCTANCE MEASUREMENTS}

Error in field specificconductance measurements can be attributed to a number of factors, the most important of which are (1) instrument misselection and drift, (2) operator-induced error, and (3)

\author{
Kenneth Scott Turner \\ U.S. Geological Survey \\ District Office - New Jersey \\ Mountain View Office Park \\ 810 Bear Tavern Road, Suite 206 \\ West Trenton, New Jersey 08628
}

improperly applied temperaturecorrection methods. The accuracy of specific-conductance measurements is essential because inaccuracies may lead to erroneous conclusions and the documenta- tion of false trends in project reports.

Instrument misselection can be minimized by carefully scrutinizing documented instrument specifications (including environmental 
operating specifications) or, when these are not available, by discussing the specifications with the manufacturer directly before purchasing an instrument. Proper training of instrument users (with theoretical as well as "hands-on" training) can help to minimize operator-induced error. Temperature-correction methodology used in most American and European commercial specific-conductance meters (a fixed 2 percent and 2.2 percent per degree Celsius, respec-: tively) does not conform to the method adopted by the U.S. Geological Survey (Friedman, L. C. and Erdmann, D. E., 1982, Quality assurance practices for the chemical and biological analyses of water and fluvial sediments: Techniques of Water-Resources Investigations of the United States Geological Survey, book 5, chapter A6, p. 51). Temperature correction, which closely matches the temperature/specificconductance relation of a $\mathbf{0 . 0 0 7 0 2}$ $\mathrm{N} \mathrm{KCl}$ solution, is applied to the raw conductivity measurement by using derived functions or by using fixed percentages when watersample temperatures are within specified water-temperature ranges.

Maintaining an awareness of the sources of error in field specificconductance measurements can help the water-quality investigator minimize errors and increase the instrument user's understanding of the limitations and "real-life" accuracy of collected and archived field specific-conductance data.

\title{
ATTENUATION OF NITROGEN AND FECAL COLIFORMS FROM SEPTIC-TANK EFFLUENT THROUGH A THICK UNSATURATED ZONE, UPPER MOJAVE RIVER BASIN, CALIFORNIA
}

\author{
Amjad M.J. Umari*, Peter Martin and Roy A. Schroeder \\ U.S. Geological Survey \\ 5735 Kearny Villa Road, Suite 0 \\ San Diego, California 92123
}

In the rapidly developing upper Mojave River basin about 130 kilometers northeast of Los Angeles, much of the wastewater from domestic and industrial septic tanks drains into seepage pits and then percolates into the unsaturated zone. Contamination of ground water resulting from the increasing quantity of wastewater discharged into the unsaturated zone is a major concern. The objectives of this study were to investigate the movement of the wastewater through the unsaturated zone and changes in concentration of fecal coliforms and nitrogen in the wastewater as it moves through the unsaturated zone to the water table. These objectives were met by investigating the transport of septictank wastewater through the unsaturated zone at eight sites (private residences) chosen to represent a range in geohydrologic conditions, number of years the seepage pit has been in operation, and loading (single- or multiplefamily dwelling).

Moisture-content profiles from neutron logs were collected periodically at sites with recently installed seepage pits. The profiles were used to define the progress of the wetting front with time and to estimate rates of vertical movement of wastewater. Vertical-movement rates ranged from 0.02 meter per day in fine-grained soils to 0.17 meter per day in sandy soils.

Soil cores from all depths and septic-tank water were analyzed for fecal coliforms. These analyses showed fecal coliform counts to drop from 100,000 colony-forming units per 100 milliliters in septic tanks to nondetectable levels in the soil cores, indicating complete removal by the unsaturated zone.

Analyses of soil-core and suctioncup-lysimeter samples indicate that, starting from a few feet below the bottom of the seepage pits and down, virtually all the nitrogen is in the form of nitrate. Nitrate- nitrogen concentrations decreased from as high as $63 \mathrm{mg} / \mathrm{L}$ (milligrams per liter) a few meters below the seepage-pit bottoms to less than 3 $\mathrm{mg} / \mathrm{L}$ at the water table. Biological tests on the soil cores revealed the presence of nitrate-reducing and denitrifying bacteria throughout most of the soil column, indicating that the decrease in nitrate with depth may be due to the microbial reduction of nitrate. Shallow ground-water samples were collected at four of the sites and showed nitrate-nitrogen concentrations to be near background levels ( 1 to $3 \mathrm{mg} / \mathrm{L}$ ).

Results of the study suggest that the relatively thick unsaturated zone ( 30 to 100 meters) in the study area effectively attenuates both fecal coliform counts and nitrogen concentrations in septic-tank wastewater. This attenuation takes place despite the relatively rapid vertical movement of the wastewater.

-Presenting author. 


\title{
GEOCHEMICAL CONTROLS ON RADIONUCLIDE MOBILITY IN SHALLOW GROUND WATER NEAR AN EPHEMERAL STREAM IN NORTHEASTERN ARIZONA
}

\author{
P. C. Van Metre*, Laurie Wirt, and J. R. Gray \\ U.S. Geological Survey \\ Water Resources Division \\ 300 W. Congress Street FB44 \\ Tucson, Arizona 85701-1393
}

Neutral Eh conditions occur in ground water underlying the Puerco River near Chambers, Arizona, and may affect uranium mobility in surface water that is recharged to the alluvial aquifer. Puerco River drams the west flank of the Grants Mineral Belt in New Mexico where uranium was mined and milled in the 1950's and from 1968 to 1986 . Radionuclides occur naturally in the basin; however, mining operations released additional radionuclides and other trace metals to surface water in the Puerco River.

Aqueous and solid-phase samples were collected from nine monitor wells and two drive points in the streambed. Aqueous-phase samples indicate two chemically distinct ground-water zones. Chemical analyses include common ions; nutrients; dissolved trace elements; selected radionuclides and environmental isotopes; and field measurements of temperature, $\mathrm{pH}$, dissolved oxygen (DO), specific conductance, and Eh. Waters from 2 to 4 feet below the streambed contained $5.4 \mathrm{mg} / \mathrm{L}$ (milligrams per liter) dissolved organic carbon, $3.3 \mathrm{mg} / \mathrm{L}$ dissolved manganese, 0.35 to $0.78 \mathrm{mg} / \mathrm{L}$ dissolved iron, $19 \mu \mathrm{g} / \mathrm{L}$ (micrograms per liter) dissolved uranium, and a field-measured $\mathrm{pH}$ of 7.7 and $\mathrm{Eh}$ of +0.1 volts. In contrast, water that is $\mathbf{1 5}$ feet below the channel and water in 6 shallow wells 30 feet or more laterally from the bank contained an average of $1.4 \mathrm{mg} / \mathrm{L}$ dissolved organic carbon, 0.24 $\mathrm{mg} / \mathrm{L}$ manganese, $0.06 \mathrm{mg} / \mathrm{L}$ iron, $10.5 \mu \mathrm{g} / \mathrm{L}$ dissolved uranium, and field-measured $\mathrm{pH}$ of 7.2 to 7.7 and Eh of +0.2 to +0.4 volts. Statistical analysis of solid-phase uranium content in bed material and wellcore samples indicates a positive correlation between uranium and clay content and a negative correlation between uranium and depth of sample. Geochemical modeling indicates that uranium will remain mobile in oxidizing waters but may precipitate as coffinite and uraninite in reducing waters.

Presenting author.

\section{STATISTICAL ANALYSIS OF WATER QUALITY OF STORMFLOW AND BASE FLOW FOR STREAMS IN THE AUSTIN AREA, TEXAS}

\author{
Jack E. Veenhuis \\ U.S. Geological Survey \\ Texas District \\ 8011 Cameron Road \\ Austin, Texas 78753
}

In 1975, the U.S. Geological Survey, in cooperation with the city of Austin, began a study that included the collection and analysis of water-quality data at 18 sampling sites on 10 streams in the Austin area. The quality of stormflow and base flow was statistically analyzed to determine the effects of watershed development on concentrations of dissolved solids, suspended solids, biochemical oxygen demand, total nitrogen, total phosphorus, and total organic carbon; and densities of fecal coliform and fecal streptococci bacteria. Concentrations of all constituents except dissolved solids and bacterial densities were significantly larger in samples collected during stormflow than during base flow. At the two sampling sites with the most urbanized watersheds, concentrations of constituents and bacterial densities analyzed in samples from the rising stage of the stormflow were more variable and significantly larger than those in samples from the falling stage of the stormflow. Samples collected from the rising stage and falling stage of the stormflow at the sampling sites with more rural watersheds had no significant difference in concentrations of constituents and bacterial densities. The 18 sampling sites were subsequently classified into four groups based on the amount of 
watershed development. The largest concentrations of constituents and bacterial densities for both the rising and falling stages of stormflow were in the samples col- lected at the groups of sites with more urbanized watersheds. For base flow, the median concentrations of constituents and bacterial densities of the samples collected at the groups of sites with more urbanized drainages also were larger; however, the differences between the groups were not always statistically significant.

\section{APPLIED RESEARCH USING CHLORINE-36 AS A HYDROGEOLOGIC TOOL}

\author{
G. Vourvopoulos* \\ Department of Physics and Astronomy \\ Western Kentucky University \\ Bowling Green, Kentucky 42101 \\ T. F. Kraemer \\ U.S. Geological Survey \\ National Center, Mail Stop 431 \\ 12201 Sunrise Valley Drive \\ Reston, Virginia 22092
}

\author{
J. V. Brahana \\ U.S. Geological Survey \\ A-413 Federal Building \\ U.S. Courthouse \\ Nashville, Tennessee 37203 \\ W. Wolfli, M. Suter, and A. Synal \\ Federal Institute of Technology \\ CH-8093 \\ Zurich, Switzerland
}

The radioisotope chlorine-36 $\left({ }^{36} \mathrm{Cl}\right)$ offers a potentially powerful tool for the hydrogeologist, not only as a technique to age date very old ground water (10 $10^{5}$ to $10^{6}$ years), but also as an environmental isotope that can be used in conjunction with other geochemical data to constrain conceptual models of regional ground-water flow and water-rock interaction. In the Gulf Coast Regional Aquifer-Systems (GC RASA) study of Cretaceous sand aquifers in the northern Mississippi embayment, ${ }^{36} \mathrm{Cl}$ analyses are being used in conjunction with other radiochemical, geochemical, and water-quality parameters to evaluate dischargeboundary locations from a deeply buried flow system. The ${ }^{36} \mathrm{Cl}$ data support flow-modeling results, strengthening the argument that major discharge boundaries overlie rift boundaries rather than permeable subcrop boundaries. A second application includes determination of ${ }^{36} \mathrm{Cl}$ concentrations in ground water from different stratigraphic intervals of the carbonate Knox Group in central and western Tennessee. Conceputal models based on these and other data allow evaluation of residence time and estimation of the degree of hydraulic isolation of highly permeable zones. Unique ${ }^{36} \mathrm{Cl}$ signatures suggest flow in distinct stratigraphic zones is isolated. A third application focuses on waterrock interaction in deeply buried ( $\sim 4100$ meters) Tertiary shales. Concentrations of ${ }^{36} \mathrm{Cl}$ are anomalously high in interstitial water from the fine-grained sediments, suggesting a hypogenic production of the radioisotope in this environment. Although the ${ }^{36} \mathrm{Cl}$ method can be used to define selected processes acting in this environment, the method is inappropriate for age dating.

*Presenting author.

\section{RESEARCH PLAN TO EVALUATE THE RELATIONS AMONG GROUND-WATER QUALITY, HYDROGEOLOGIC CONDITIONS, AND HUMAN ACTIVITIES IN THE NORTHERN ATLANTIC COASTAL PLAIN}

\author{
Eric F. Vowinkel* \\ U.S. Geological Survey \\ 810 Bear Tavern Road, Suite 206 \\ West Trenton, New Jersey 08628
}

\author{
Steven F. Siwiec \\ U.S. Geological Survey \\ 5 Aerial Way \\ Syosset, New York 11791
}

The U.S. Geological Survey is developing a research plan for a study that will statistically test hypotheses concerning relations among ground-water quality, hydrogeologic conditions, and human activities in the Atlantic Coastal Plain physiographic province. The Coastal Plain in 
New York, New Jersey, and Pennsylvania, which covers about 5,000 square miles, was selected for intensive study because hydrogeologic and climatic conditions generally are similar throughout the area. Previous investigations found similar relations among land use and the presence or concentrations of inorgamic and organic contaminants, including metals, nutrients, volatile organic compounds, and pesticide residues in the New York and New Jersey Coastal Plain.
The objectives of the current study are to (1) verify previous methods of quantifying human activities within circular buffer zones about wells to determine whether inferences about land use and other human activities that affect ground-water quality can be extrapolated beyond the original study areas; (2) determine the effect of spatial and temporal variations in water quality, hydrogeologic conditions, and other factors on these methods; (3) develop, test, and verify new methods of characterizing human activities and hydrogeologic conditions that incorporate detailed information on point and nonpoint sources of contaminantion and contributing areas to wells; (4) assess the influence of human activities on water quality in deep parts of the aquifer systems; and (5) evaluate the utility of a massbalance approach for conducting regional ground-water-quality appraisals for selected contaminants.

*Presenting author.

\section{DELINEATION OF CONTAMINATED GROUND-WATER DISCHARGE ZONES USING ANALYSIS OF BOTTOM-SEDIMENT METHANE BUBBLES, CANAL CREEK, MARYLAND}

\author{
Don A. Vroblesky* \\ U.S. Geological Survey \\ 1835 Assembly St., Suite 677A \\ Columbia, South Carolina 29201
}

\author{
Michelle M. Lorah \\ U.S. Geological Survey \\ 208 Carroll Building \\ 8600 LaSalle Rd. \\ Towson, Maryland 21204
}

\begin{abstract}
To test the hypothesis that part of the volatile-organic ground-water contaminants discharging into Canal Creek, Aberdeen Proving Ground, Maryland, may partition into naturally-occurring methane bubbles in creek-bottom sediment, sediment-gas bubbles were collected along the tidal creek. The sample-collection method developed for this study consisted of capturing methane bubbles in a polyethylene bag and immediately transferring them by syringe to glass tubes containing wires coated with an activated-carbon adsorbent. Relative concentrations in terms of ion counts were
\end{abstract}

determined by mass spectral analysis for several chlorinated volatile organic compounds. Samples were collected from 17 sites with 5 replicates.

Concentrations of chlorinated volatile compounds were markedly greater (by about 0.7 to 4 orders of magnitude) in methane bubbles collected from parts of Canal Creek adjacent to ground-water contamination than in bubbles collected from parts of the creek distant from known sources of ground-water contamination. Furthermore, bubbles collected from parts of the creek adjacent to an area previously thought to be uncont aminated contained elevated ion counts of chlorinated volatile compounds. Ground-water samples subsequently collected in this area were found to contain elevated concentrations of the same volatile constituents. The success of bubble analysis in locating a previously unknown area of contamination indicates that the method may be a valuable tool for delineating zones where volatile organic contaminants in ground water are discharging into surface water bodies.

*Presenting author. 


\author{
Susan H. Wayland \\ Environmental Protection Agency \\ 401 M Street, SW \\ Washimgton, DC 20406
}

The Agency released for public comment Agricultural Chemicals in Ground Water: Proposed Pesticide Strategy in February 1988. The strategy lays out the conceptual framework for addressing the problem of pesticides contamination of ground water and combines Federal and State efforts to achieve a synergistic effect.

The strategy's goal is to prevent unacceptable contamination of current and potential sources of ground water by pesticides. The strategy provides a consistent national goal for health and environmental protection providing States the opportunity to be more stringent. With a focus on prevention, EPA wants to reduce the likelihood of unacceptable levels being reached by adopting an "early-warning approach" where increasingly stringent pesticide management measures would be imposed on pesticide use in response to monitoring data showing pesticide contamination levels moving toward the maximum contaminant level or other reference point. Due to the local nature of ground water, EPA prefers that
States implement plans that tailor management measures to local ground water protection needs. For pesticides posing ground water concerns, EPA would base Federal registration on a State management plan for pesticides in ground water. At this time, the Agency is revising the strategy in lieu of comments raised during the public comment period and State workshops on management plans held this past fall and winter, and hopes to release a final agency pesticides-inground-water strategy this spring/summer.

\section{CONSIDERATIONS IN INTERPRETING MERCURY CONCENTRATIONS IN WATER SAMPLES COLLECTED BY THE U.S. GEOLOGICAL SURVEY}

\author{
Wayne E. Webb \\ U.S. Geological Survey \\ Northeastern Region Headquarters \\ 12201 Sunrise Valley Drive, MS 433 \\ Reston, Virginia 22092
}

Mercury concentrations in water reported by the U.S. Geological Survey are more difficult to interpret than many other trace-metals because of sampling and contamination problems unique to the element and to Survey field operations. Evidence of contamination and loss of mercury have been documented.

Survey mercury data are useful but require careful interpretation. Prior to 1980, the primary source of sample contamination was mercury used in field equipment. The likelihood of sample contamination by mercury increased in $\mathbf{1 9 8 0}$ when mercuric chloride was introduced as the preservative for nutrient water samples. Water samples were contaminated with mercury by direct transfer during sampling and by migration of vapor into samples stored in polyethylene bottles. Sample contamination appears to have occurred in almost every District of the Water Resources Division. Several instances of sample contamination have been documented through interBecause mercury also was being lost from polyethylene sample bottles, consistent detections of mercury in water samples could indicate that the samples had even higher mercury concentrations than reported. Similarly, lack of detection would not assure that agency quality-assurance activities. the original sample was uncontaminated.

Beginning in 1984, mercury samples have been protected in glass bottles and preserved with acid and potassium dichromate. Because of this improvement in sample preservation, consistent mercury concentrations in samples from a site probably represent the actual mercury concentration in the samples. Conversely, sporadic and illogical detections of mercury possibly document sample contamination. The new preservation techniques also assure that the lack of detectable mercury in a sainple represents an actual absence of mercury rather than the loss of mercury. 


\author{
Dennis A. Wentz \\ U.S. Geological Survey \\ 6417 Normandy Lane \\ Madison, Wisconsin 53719
}

During the period August 1981 through September 1986, snowpack $\mathrm{pH}$ was about 4.7 at the beginning of spring snowmelt at Round and East Eightmile Lakes in northwestern Wisconsin. Water equivalent of the snowpack averaged 117 millimeters. Most of the hydrogen ion (87.4 to 87.9 percent during spring 1986) was removed from the snowpack during the early stages of melting (53.1 to 65.2 percent of water equivalent lost), implying that $\mathrm{pH}$ of the initial infiltrate was less than 4.7.

Cation exchange occurred in localized areas during passage of percolating snowmelt to the water table, but mineralogic analyses and chemical-equilibrium considerations suggest that silicate hydrolysis was the primary process buffering low $\mathrm{pH}$ snowmelt and rainfall during flow through the soils and withim the ground-water systems of these unconfined, sandy outwash aquifers. As the associated reactions consumed hydrogen ion, they contributed calcium, magnesium, potassium, sodium, silica, and alkalinity to the solutions. At depths of 12 to 18 meters below the water table, ground-water $\mathrm{pH}$ reached a maximum of about 9 , and calcite saturation often was exceeded, possibly causing deposition of secondary calcite. Sulfide minerals were not found in the aquifers, and sulfate, chloride, and inorgamic nitrogen in ground water apparently resulted from atmospheric contributions. Longterm decreases of silica concentrations in shallow ground water at both study areas, and decreases of alkalinity concentrations and $\mathrm{pH}$ in shallow ground water at Round Lake, probably resulted from dilution and(or) neutralization by above-normal volumes of acidic precipitation.

\section{ANALYSIS OF VARIANCE IN THE SAMPLING OF STREAMBED MATERIALS FOR ANTHROPOGENIC ORGANIC COMPOUNDS}

\author{
Kevin D. White \\ U.S. Geological Survey, WRD \\ Kentucky District \\ 2301 Bradley Avenue \\ Louisville, Kentucky 40217
}

In order to properly design field studies for the purpose of assessing the occurrence and distribution of anthropogenic organic compounds in streambed sediments, an understanding of the variance associated with field sampling and laboratory analysis is needed. To develop such understanding, a field study was designed as part of the Kentucky River basin National Water Quality Assessment pilot study with the following objectives: 1) to determine the appropriate particle size fraction to sample, and 2) to determine the relative mag- nitudes of variation associated with field sampling, field processing, and laboratory analysis.

Three independent streambedmaterial samples were collected at each of three stream sites in the Kentucky River basin. Each independent sample was processed using wet-sieving techniques into three size fractions: less than 2 millimeters, less than 2 millimeters but greater than 63 micrometers, and less than 63 micrometers. Three subsamples were taken from one size fraction at each site. All samples were soxlet extracted and analyzed for base/neutral and organochlorine compounds by gas chromatography/mass spectroscopy.

Results indicate that the less than 2 millimeter size fraction is most appropriate for determining concentrations of hydrophobicorganic compounds in bottom sediment. Analysis of variance shows that most variance is associated with differences between size fractions and differences between sampling sites. Sample variation within a given site and subsample variation within a size fraction are small. 


\section{RELATION OF STORM-WATER PERCOLATE TO GROUND-WATER QUALITY AT THREE STORM-WATER-MANAGEMENT FACILITIES IN MARYLAND}

\author{
Franceska D. Wilde \\ U.S. Geological Survey \\ Mid-Atlantic District \\ 208 Carroll Building \\ 8600 Lasalle Road \\ Towson, Maryland 21204
}

Concern over nonpoint-source pollution of the Chesapeake Bay has resulted in the enactment of legislation in Maryland requiring the discharge of urban runoff to impoundment structures, where the storm water is allowed to percolate through the unsaturated zone. The effect of storm-water infiltration on ground-water quality is being studied at three storm-water-management facilities in Maryland.

Data on the chemistry of storm water, vadose water, and ground water have been collected during 1986-89. Storm water is a bicarbonate-type water. When road salting occurs, however, chloride becomes the dominant anion. Inorganic contaminants in the storm water sampled include arsenic, barium, cadmium, chloride, chromium, cobalt, copper, lead, molybdenum, nickel, nitrate, vanadium, and zinc. The majorand trace-element chemistry of vadose water (collected from approximately 2 feet beneath two of the storm-water impoundments) generally mimics that of storm water. However, arsenic and lead were not detected, and barium, chloride, chromium, and cobalt were at concentrations greater than those in storm water in some samples.
The relation of storm-waterpercolate quality to ground-water quality is seen in the chemistry of ground water beneath storm-water impoundments. Ground water was modified to a sodium chloride-type water from a sodium chloride/calcium bicarbonate-type, magnesium nitrate-type, and calcium bicarbonate-type water at respective control sites. Constituents found in ground water beneath the impoundments that were not detected or were detected at markedly lower concentrations in ambient ground water include barium, cadmium, chloride, cobalt, lead, molybdenum, nickel, vanadium, and zinc.

\section{DISTRIBUTION OF TRACE METALS IN SEDIMENT AT PICATINNY ARSENAL, NEW JERSEY}

\author{
Stephen A. Wilson* and Paul H. Briggs \\ U.S. Geological Survey \\ P.O. Box 25046, Mail Stop 973 \\ Denver, Colorado 80225
}

The Picatinny Arsenal in upstate New Jersey has been the site of military munitions productions since World War II. Part of the munitions production required the use of an elaborate electroplating operation. In the past, untreated electroplating wastes migrated directly into Bear Swamp Brook which runs adjacent to the plating facility. Analysis of the sediment in Bear Swamp Brook has revealed elevated concentrations of selected trace metals. Concentrations of chromium, copper, lead, and zinc were as high as $12,000,4,000,2,000$, and $6,000 \mathrm{ppm}$ respectively.

Concentrations of silver, mercury, tin, and nickel were also high $(56,5,70$, and $150 \mathrm{ppm}$, respectively). Collection ponds excavated in Bear Swamp Brook to contain sediment have not totally prevented the transport of con- taminated sediment downstream The highest concentrations of metals in the sediment occur more than 1,000 feet downstream from the collection ponds.

This study provides information on (1) lateral and vertical distribution of metals in the stream sediment, (2) metal phase associations, and (3) the implication for local water system contamination.

*Presenting author. 


\author{
Laurie Wirt*, J. R. Gray, and P. C. Van Metre \\ U.S. Geological Survey \\ Water Resources Division \\ 300 W. Congress Street FB44 \\ Tucson, Arizona 85701-1393
}

Measured gross alpha plus gross beta activities in the Puerco River, an intermittent tributary of the Little Colorado River, are as great as 7,000 picocuries per liter ( $\mathrm{pCi} / \mathrm{L}$ ) and exceed Arizona's maximum contaminant level of $30 \mathrm{pCi} / \mathrm{L}$. Most activity is in the suspended phase; suspended-sediment concentrations commonly exceed 100,000 milligrams per liter. The activity includes naturally occurring radionuclides and effluent from uranium-mine operations in the Grants Mineral Belt of New Mexico in the Puerco River headwaters. Significant dewatering of mines began in the late 1960's and continued until 1986. The failure of a tailings-pond dike in 1979 resulted in the largest known single release of uranium-tailings liquid in United States history. As part of a 5-year study, shallow drive points in the streambed, nearstream clusters of wells, and a network of five surface-water stations are used to monitor variations of geochemical constituents and radionuclides in streamflow and in the shallow alluvial aquifer. Common ions, trace elements, gross alpha and gross beta, tritium, deuterium, oxygen-18, sulfur-34, radium- 226 and 228 , thorium- 230 and 232, lead-210, polonium-210, and uranium-234, 235, and 238 were measured in streamflow and ground water. Sampling results for dissolved gross alpha and uranium from a multiple well site are negatively correlated to depth. Variation in values of tritium isotopes, oxygen-18 to deuterium ratios, uranium, and trace elements appear to distinguish recently infiltrated runoff from older background waters. Relations among sulfur and uranium isotope ratios are less apparent because these constituents are significantly affected by processes including leaching, sorption by clays, and transport through shallow reducing zones below the streambed.

"Presenting author.

\title{
PRIMARY PRODUCTION OF BIG LAKE, SOUTH-CENTRAL ALASKA
}

\author{
Paul F. Woods \\ U.S. Geological Survey \\ 230 Collins Road \\ Boise, Idaho 83702
}

The annual integral primary production of Big Lake was determined in 1984 as part of a 2-year study of the limnological characteristics and trophic state of the 1,213-square-hectometer lake in south-central Alaska. Hourly photoassimilation rates were measured using the carbon- 14 light and dark bottle method adapted to a constant-light, water-bath incubator. These results were input to a model which used selected limnological data and hourly solar-irradiance data to compute daily integral primary production.

Daily integral primary production, in milligrams of carbon fixed per square meter, varied from less than 0.1 in January to 298.4 in July. During the 6 months when the lake was covered with ice, daily integral primary production did not exceed 60 milligrams of carbon fixed per square meter because of cold water temperatures, a shallow euphotic zone, and limited quantities of in-situ photosynthetically active radiation. During the ice-free period, May through October, the lake produced 90 percent of its annual integral primary production of 29.6 grams of carbon fixed per square meter. During the same period, the lake received 76 percent of its annual input of solar irradiance.

Annual integral primary production in Big Lake during 1984 was characteristic of oligotrophic lakes. The range in daily integral primary production for Big Lake was comparable to that measured in several other subarctic Alaskan lakes. 


\title{
BOTANICAL COMMENTS ON TREES AS CHEMICAL RECORDERS OF GROUND-WATER CONTAMINATION
}

\author{
Thomas M. Yanosky* \\ U.S. Geological Survey \\ National Research Program \\ National Center, Mail Stop 461 \\ Reston, Virginia 22092
}

\author{
Don A. Vroblesky \\ U.S. Geological Survey \\ 1835 Assembly Street, Suite 677A \\ Columbia, South Carolima 29201
}

The multielement analysis of tree rings provides a means of assessing the extent and rates of movement of pollutants in ground water. Trees growing over shallow aquifers may take up contaminants and incorporate them in tissues. Concentrations of elements in annual-growth rings must first be compared to corresponding rings in trees from uncontaminated areas. Concentrations of many elements generally are greater in the functional water-conducting rings than in inner, metabolically inactive rings. Additionally, some elements seemingly are mobile across ring boundaries, and the extent to which some elements accumulate may be strongly species related.

Wood samples removed from living trees were analyzed by a proton beam that conformed to the approximate widths of individual rings or parts of rings as narrow as 1.0 millimeters. The inner, middle, and outer parts of rings of tulip trees did not have consistent positional differences in element content. A similar study of pin oak, southern red oak, and sassafras did not reveal a tendency for elements to accumulate selectively in the earlywood or latewood of individual rings. When consecutive rings were analyzed along different radii from the same tree, the year-toyear trends among radii were consistent despite some differences in absolute elemental concentrations. We conclude that concentration trends of elements along a series of consecutive rings can provide a great deal of information about the history of ground-water pollution, but results must be evaluated in light of physiological and transport processes.

*Presenting author.

\section{IMPROVING SENSITIVITY AND CONTROLLING ENHANCEMENT EFFECTS IN DIRECT CURRENT PLASMA OPTICAL EMISSION SPECTROSCOPY}

\author{
Edward J. Zayhowski* and Mark R. Hill \\ U.S. Geological Survey \\ National Water Quality Laboratory \\ Inorganic Program \\ 5293-B Ward Road \\ Arvada, Colorado $\mathbf{8 0 0 0 2}$
}

In 1988, the U.S. Geological Survey's National Water Quality Laboratory in Denver, Colorado, analyzed about 24,000 natural water samples for aluminum, boron, and chromium by direct current plasma optical emission spectroscopy (DCP-OES). Filtered and digested natural water samples were analyzed for dissolved and total-recoverable aluminum, boron, and chromium by this technique. The DCP-OES technique was chosen instead of the inductively coupled plasma optical emission spectroscopy (ICP-OES) technique because of its capability to analyze a wider variety of water samples and to achieve excellent precision and accuracy. Enhancement and suppression effects from alkali and alkaline earth metals are common in DCP-OES. To overcome these effects, a sample matrix modification technique, utilizing lithium chloride and glycerin, was used. Improved sensitivity and control of enhancement mechanisms from alkali and alkaline earth metals resulted from this modification. A comparison of precision, accuracy, and detection limits with the alternative techniques of ICP-OES, graphite-furnace atomic-absorption spectroscopy, and flame atomic-absorption spectroscopy with chelation extraction are presented.

- Presenting author. 


\section{SOURCES AND MAGNITUDE OF ERROR ASSOCIATED WITH VARIOUS TECHNIQUES OF ESTIMATING NUTRIENT AND SUSPENDED-SEDIMENT LOADS FROM THE SUSQUEHANNA RIVER BASIN TO THE CHESAPEAKE BAY}

\author{
Linda D. Zynjuk* \\ U.S. Geological Survey \\ Water Resources Division \\ 208 Carroll Building \\ 8600 LaSalle Road \\ Towson, Maryland 21204
}

\author{
Robert M. Summers \\ Maryland Department of the Environment \\ Chesapeake Bay and Special Projects Division \\ 2500 Broening Highway \\ Baltimore, Maryland 21224
}

The quality of water in the Chesapeake Bay has degraded in recent decades, apparently in response to increased nutrient and suspended-sediment loads from the surrounding drainage basin. The Susquehanna River constributes approximately 50 percent of the freshwater inflow to the Chesapeake Bay; consequently, the constituent loads transported by Susquehanna River strongly influence its water quality. In an effort to improve Chesapeake Bay water quality, Pennsylvania, Maryland, and Virginia began a major effort to reduce point and nonpoint-source pollution

Timothy A. Cohn

U.S. Geological Survey

Branch of Systems Analysis

12201 Sunrise Valley Drive, Mail Stop 410

Reston, Virginia 22092

throughout the drainage basin, and thereby reduce constituent loads entering the Bay.

A comprehensive water-quality monitoring program has been established to quantify changes or improvements in nutrient and suspended-sediment loads resulting from pollution control efforts in the Susquehanna River basin. The large data base created as part of the ongoing monitoring prograns has additionally been used to investigate methods for improving estimates of constituent loads by examining sources and magnitude of error associated with existing load-estimation techniques.
The following sources of error were evaluated: (1) Inappropriate transformations, of log-based regression equations, (2) incorrect model specification, (3) use of regression equations on unstratified data sets, and, (4) improper sampling design. Preliminary results suggest that proper transformation of log-based regression equations and specification of time and seasonality terms in the model result in more accurate load estimates. Relative magnitudes of these various sources of error will be presented.

-Presenting author. 